\title{
ENGENHARIA DE TRANSPORTES NO ENSINO DE GRADUAÇÃO: COMPETÊNCIAS, HABILIDADES, PROCESSO DE ENSINO- APRENDIZAGEM E AVALIAÇÃO
}

\author{
Carlos Alberto Prado da Silva Junior
}

Orientador

PROF. ASSOC. ANTÔNIO NÉLSON RODRIGUES DA SILVA

Tese apresentada à Escola de Engenharia de São Carlos da Universidade de São Paulo para obtenção do título de Doutor em Ciências no Programa de Pós-Graduação em Engenharia de Transportes. 


\section{AUTORIZO A REPRODUCÃO TOTAL OU PARCIAL DESTE TRABALHO, POR QUALQUER MEIO CONVENCIONAL OU ELETRÔNICO, PARA FINS DE ESTUDO E PESQUISA, DESDE QUE CITADA A FONTE.}

\footnotetext{
competências, habilidades, processo de ensino-aprendizagem e avaliação / Carlos Alberto Prado da Silva Junior; orientador Antônio Nélson Rodrigues da Silva. São Carlos, 2014.

Tese (Doutorado) - Programa de Pós-Graduação em Engenharia de Transportes e Área de Concentração em Planejamento e operação de Sistemas de Transporte -Escola de Engenharia de São Carlos da Universidade de São Paulo, 2014.

1. Engenharia de transportes. 2 . Ensino-aprendizagem. 3. Avaliação da aprendizagem. 4. Aprendizagem ativa. 5. Mapas conceituais. I. Título.
}

da Silva Junior, Carlos Alberto Prado

Engenharia de transportes no ensino de graduação: 


\section{FOLHA DE JULGAMENTO}

Candidato: Engenheiro CARLOS ALBERTO PRADO DA SILVA JUNIOR

Título da tese: "Engenharia de transportes no ensino de graduação: competências, habilidades, processo de ensino-aprendizagem e avaliação"

Data da defesa: 04/08/2014

\section{Comissão Julgadora:}

Resultado:

Prof. Associado Antônio Nélson Rodrigues da Silva (Orientador)

(Escola de Engenharia de São Carlos/USP)

APROUNDN

Profa. Dra. Cira Souza Pitombo

APROVADO

(Escola de Engenharia de São Carlos/USP)

Dra. Nídia Pavan Kuri

APROVADO

(Escola de Engenharia de São Carlos/USP)

Prof. Dr. Márcio de Almeida D'Agosto

ARBOVDRO

(Universidade Federal do Rio de Janeiro/UFRJ)

Profa. Dra. Fabiana Serra de Arruda

APROUADO

(Universidade de Brasília/UnB)

Coordenador do Programa de Pós-Graduação em Engenharia de Transportes:

Prof. Associado Paulo César Lima Segantine

Presidente da Comissão de Pós-Graduação:

Prof. Associado Paulo César Lima Segantine 

Dedico este trabalho a minha esposa Heliana, com amor e agradecimento pelo apoio ao longo de todos esses anos, principalmente durante o desenvolvimento desta pesquisa; seu apoio e presença, suas palavras de carinho e de motivação foram fundamentais para a realização deste trabalho. 

A Deus, por iluminar todos os meus passos;

Aos meus pais Carlos Alberto Prado da Silva e Maria Odelita Costa da Silva (In Memorian), pelo amor e orientação necessários à minha caminhada;

Ao meu irmão Cristiano Ricardo Costa da Silva e ao sobrinho Clóvis Mateus Lima da Silva, por sempre estarem comigo;

À minha Avó Anita Gomes de Araújo, por cuidar e orar sempre por mim;

Aos meus sogros Edimar Pereira Fontenele e Margarida Barbosa Fontenele, pela amizade e carinho;

Aos queridos amigos Lucy e Everaldo Pletz, por todo carinho e orações;

Aos queridos amigos Simone e Benedito Gomes, pela atenção e carinho;

Ao Professor Associado Antônio Nélson Rodrigues da Silva, pela orientação, apoio, compreensão e liberdade de trabalho;

Ao Professor Adjunto Márcio de Almeida D'Agosto e à Doutora em Ciências de Engenharia de Transportes Suellem Deodoro Silva, pelo apoio e troca de experiências durante a realização desta tese;

À Dra. Nidia Pavan Kuri, pela valiosa colaboração pedagógica para a realização desta tese;

À Professora Adjunta Cira de Souza Pitombo, do Departamento de Engenharia de Transportes da Escola de Engenharia de São Carlos - USP, pelo apoio aos experimentos realizados nesta tese;

À professora Associada Nadia Aparecida de Souza, da Universidade Estadual de Londrina, pelas sugestões e contribuições relativas ao uso de mapas conceituais como instrumentos de avaliação da aprendizagem;

Ao Departamento de Engenharia de Transportes da Escola de Engenharia de São Carlos Universidade de São Paulo, pela infraestrutura disponibilizada para a realização desta tese;

À Universidade Estadual de Londrina - UEL, ao Centro de Tecnologia e Urbanismo - CTU, ao Departamento de Construção Civil - DCCi em especial aos Professores Carlos José Marques da Costa Branco, Berenice Martins Toralles, Deize Dias Lopes, e Raquel Souza Teixeira pelo apoio a realização desta tese;

À Universidade Estadual do Oeste do Paraná - UNIOESTE, ao Centro de Ciências Exatas e Tecnologias (CCET) e aos seus professores, pelo apoio à minha licença em tempo integral para a realização do programa de doutorado;

Aos professores do Colegiado de Engenharia Agrícola da UNIOESTE, Centro de Ciências Exatas e Tecnologias (CCET), em especial aos Professores Divair Christ, Silvia Renato Machado Coelho e Silvio Cesar Sampaio, pela grande ajuda em diversos momentos ao longo da realização deste trabalho; 
Ao professor do Colegiado de Engenharia Civil da UNIOESTE, Centro de Ciências Exatas e Tecnologias (CCET), Júlio Pacheco Monteiro Neto, pelo apoio à minha licença;

Aos alunos dos cursos de Engenharia Agrícola e Engenharia Civil da UNIOESTE/CCET, Campus Cascavel, pelo respeito e momentos de aprendizagem em sala de aula, laboratórios, visitas técnicas e eventos acadêmicos;

Aos alunos do 4ํ ano das Turmas 1000 e 2000 do ano de 2014 do Curso de Engenharia Civil da UEL/CTU/DCCi, pela acolhida na minha chegada a esta instituição;

Aos alunos das turmas do $3^{\circ}$ ano do Curso de Engenharia Civil nos anos de 2011, 2012 e 2013, da Escola de Engenharia de São Carlos - USP, pela contribuição aos experimentos desenvolvidos nesta tese;

Aos amigos de pós-graduação, Bruno Mamede, Peolla Paula Stein, Thais Guerreiro e Thiago Ramos, pelo apoio e companheirismo nos anos de trabalho no STT;

A todos os colegas, funcionários e professores do Departamento de Engenharia de Transportes da EESC/USP que direta ou indiretamente contribuíram para 0 desenvolvimento desta pesquisa. 


\section{RESUMO}

DA SILVA JUNIOR, C. A. P. Engenharia de transportes no ensino de graduação: competências, habilidades, processo de ensino-aprendizagem e avaliação. 2014. 199p. Tese (Doutorado). Escola de Engenharia de São Carlos, Universidade de São Paulo, São Carlos, 2014.

O ensino de graduação em engenharia deveria estar amparado nos seguintes aspectos: $i$ ) especificação de objetivos educacionais alinhados com os conteúdos das principais áreas de conhecimento e com as competências e habilidades pretendidas; ii) delimitação das estratégias de ensino-aprendizagem; e iii) os mecanismos de avaliação da aprendizagem. Este trabalho teve como objetivo introduzir, monitorar e avaliar alterações em uma abordagem pedagógica que mesclou aulas expositivas e aprendizagem ativa, concebida com o propósito de ampliar competências e habilidades de alunos de graduação para a área de Engenharia de Transportes. Esta abordagem envolveu processo de ensinoaprendizagem e avaliação da aprendizagem por meio das análises da aquisição de competências e habilidades dos alunos. Foram desenvolvidos estudos em uma disciplina que tratou de Planejamento e Análise de Sistemas de Transportes. Estes estudos envolveram o planejamento, o desenvolvimento e a avaliação do processo de ensinoaprendizagem. As atividades foram desenvolvidas em dois períodos letivos e em turmas diferentes. No primeiro período letivo apenas uma turma da referida disciplina participou dos experimentos. Já no segundo período letivo houve a participação de duas turmas da disciplina de Planejamento e Análise de Sistemas de Transportes. Os resultados indicam que o uso das estratégias de ensino-aprendizagem adotadas e de avaliação que combinou provas e mapas conceituais parece promissor e pode garantir um processo mais fidedigno. Além disso, o formato diferenciado da disciplina, que mesclou aulas expositivas, e-learning e aprendizagem ativa, possibilitou a aquisição de competências e habilidades de domínio conceitual. Com base nestes resultados foi também possível apresentar uma proposta de ensino integrado em graduação de Engenharia de Transportes baseada na abordagem testada neste trabalho e que poderá compor um Regime de Estudos Especiais em Engenharia de Transportes.

Palavras-chave: Engenharia de Transportes. Ensino-Aprendizagem. Avaliação da Aprendizagem. Aprendizagem Ativa. Mapas Conceituais. 

DA SILVA JUNIOR, C. A. P. Transportation engineering education for undergraduate students: competencies, skills, teaching-learning and evaluation.2014. 199p. Thesis (Ph.D.). Engineering School of Sao Carlos, University of Sao Paulo, Sao Carlos, 2014.

In general terms, engineering education at the undergraduate level should be based on the definition of at least three essential elements: $I$ ) learning outcomes aligned not only with theoretical contents but also with competencies and skills, ii) effective teaching-learning strategies; and iii) appropriate methods for the evaluation of the learning outcomes. Based on this assumption, the objective of this study was to introduce, monitor and evaluate changes in a pedagogical approach that combines traditional lectures and active learning into one strategy to help in the development of competencies and skills demanded by the transportation engineering profession. An experiment was conducted for the specific case of the course Planning and Analysis of Transport Systems, in three phases: i) planning the teaching-learning process; ii) evaluation of the teaching-learning process; and iii) evaluation of the teaching-learning product. The activities were conducted in two academic semesters and with different classes. In the first semester, only one class took part of the experiment, whereas in the second semester two classes were considered. The results suggest that the teaching-learning and evaluation strategies tested, which combine exams and conceptual maps, are valuable alternatives for education and training of transportation engineers. In addition, the course format, which combined conventional classes, e-learning and active learning, led to the acquisition of competencies and abilities that are part of the conceptual domain. The outcomes of the experiment were then used in the development of a proposal for a Special Studies Program in Transportation Engineering. Although the case considered here was meant as part of a Civil Engineering degree, this integrated education program could be applied in combination with different undergraduate degrees.

Keywords: Transportation Engineering. Teaching-learning. Evaluation of the Learning. Active Learning. Conceptual Maps. 



\section{LISTA DE FIGURAS}

Figura 1.1: Interdisciplinaridade da Engenharia de Transportes

Figura 2.1: Representação esquemática da escala do índice de estilo de aprendizagem de Felder e Soloman (2004)

Figura 2.2: Instrumento para caracterizar o estilo das aulas - Desenvolvido por Silva Junior et al. (2013a) 34

Figura 2.3: Exemplo de mapa conceitual. 52

Figura 3.1: Resumo do método aplicado nesta pesquisa. 63

Figura 4.1: Distribuição geral das turmas em função do ILS - Index of Learning Styles (Dimensões ativo-reflexivo e sensorial-intuitivo) e do Classificador de Temperamentos (Dimensões extrovertido-introvertido e sensorial-intuitivo). 68

Figura 4.2: Distribuição geral das turmas em função do ILS - Index of Learning Styles (Dimensões visual-verbal e sequencial-global) e do Classificador de Temperamentos (Dimensões racional-emocional e judicativo-perceptivo) 69

Figura 4.3: Tabela de conhecimentos para a disciplina de Planejamento e Análise de Sistemas de Transportes 71

Figura 4.4: Estilo das aulas expositivas $x$ preferências de aprendizagem dos alunos - Turma

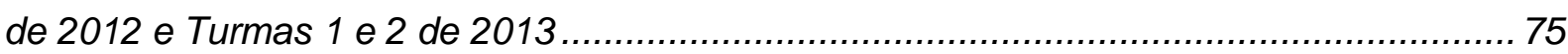

Figura 4.5: Avaliação do conteúdo disciplina .............................................................. 77

Figura 4.6: Atividades que mais contribuíram para o aprendizado ..................................... 79

Figura 4.7: Avaliação do aprendizado em relação à outras disciplinas do curso ................. 79

Figura 4.8: Avaliação global dos alunos em relação à disciplina. 80

Figura 4.9: Opinião dos alunos sobre a possibilidade de fazer outra disciplina neste formato 81

Figura 4.10: Avaliação dos alunos em relação à proposta da disciplina...... 82

Figura 4.11: Percepção dos alunos a respeito dos seus próprios desempenhos na disciplina

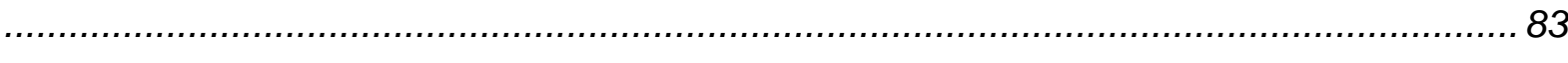

Figura 4.12: Percepção dos alunos em relação ao tempo dedicado à disciplina.................. 84

Figura 4.13: Contato dos alunos com sistema Col ou TIDIA-Ae...................................... 85

Figura 4.14: Percepção dos alunos em relação as plataformas online. 86

Figura 4.15: Percepção dos alunos em relação ao nível de exigência das atividades online87 Figura 4.16: Meios de interação favoritos disponibilizado na disciplina. 88 Figura 4.17: Percepção dos alunos a respeito dos seus desempenhos na atividade de aprendizagem ativa 89

Figura 4.18: Percepção dos alunos sobre o nível de interação nas atividades em grupo..... 90 
Figura 4.19: Percepção dos alunos em relação às atividades de aprendizagem ativa

Figura 4.20: Percepção dos alunos sobre a formação do espírito crítico nas atividades

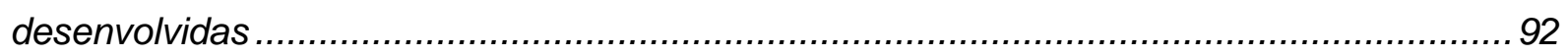

Figura 4.21: Diferenças na avaliação do conteúdo.....................................................93

Figura 4.22: Diferenças relativas a atividade que mais contribuiu para o aprendizado dos conteúdos da disciplina.

Figura 4.23: Diferenças relativas a atividade que mais contribuiu para o aprendizado dos conteúdos da disciplina.

Figura 4.24: Diferenças sobre a receptividade a disciplinas que mesclam aulas tradicionais e aprendizagem ativa em relação a disciplinas que são puramente tradicionais. 95

Figura 4.25: Diferenças entre os percentuais de alunos que já havia acessado o sistema TIDIA-Ae. 96

Figura 4.26: Diferenças entre os percentuais de alunos na utilização do sistema TIDIA-Ae 96 Figura 4.27: Diferenças entre os percentuais de alunos sobre a navegação nas páginas do sistema TIDIA-Ae.

Figura 4.28: Diferenças entre os percentuais de alunos sobre a avaliação do TIDIA-Ae......97

Figura 4.29: Avaliação geral dos mapas conceituais - Turma 2012 ................................. 100

Figura 4.30: Avaliação geral dos mapas conceituais - Turma 1 - 2013 ............................. 101

Figura 4.31: Avaliação geral dos mapas conceituais - Turma 2 - 2013 ............................. 103

Figura 4.32: Percepção dos alunos em relação ao tempo disponível para a confecção dos

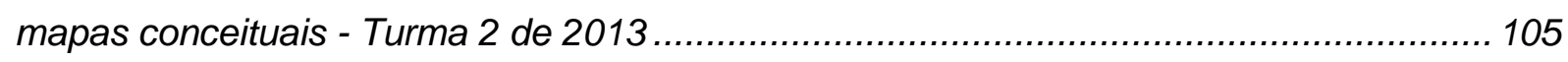

Figura 4.33: Percepção dos alunos em relação a quantidade de conceitos sugeridos para a confecção dos mapas conceituais - Turma 2 de 2013 105

Figura 4.34: Percepção dos alunos em relação as dificuldades para confeccionar os mapas

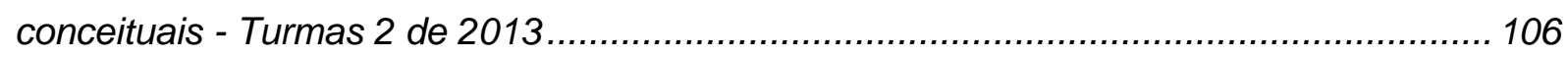

Figura 4.35: Percepção das dificuldades para a confecção dos mapas conceituais 107 Figura 4.36: Percepção sobre o uso dos mapas conceituais como ferramenta da avaliação da aprendizagem - Turma 2 de 2013 108 Figura 4.37: Percepção sobre a versão final do mapa conceitual ser representativa da média final na disciplina - Turma 2 de 2013. 109

Figura 4.38: Percepção sobre o uso do CmapTools em outras atividades - Turma 2 de 2013 110

Figura 4.39: Opinião geral sobre os mapas conceituais - Turma 2 de 2013. 111

Figura 4.40: Opinião geral sobre os mapas conceituais - Turma 2 de 2013. 111 Figura 4.41: Proposta de Áreas de conhecimento e disciplinas para comporem um Regime de Estudos Especiais em Engenharia de Transportes, bem como suas relações e interrelações. 
Figura 4.42: Mapa conceitual representativo do Regime de Estudos Especiais em

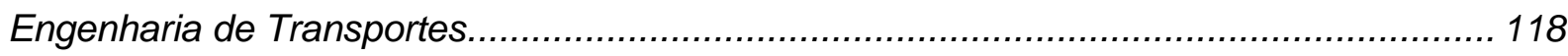



Tabela 1.1- Carga horária percentual das áreas em cursos de Engenharia Civil no Brasil .. 26

Tabela 2.1 - Software livre para construção e manipulação de mapas conceituais 54

Tabela 3.1 - Etapas desenvolvidas para as turmas de 2012 e 2013 59

Tabela 4.1: Organizadores prévios extraídos da primeira versão dos mapas conceituais.... 66 Tabela 4.2: Tipos básicos de cada grupo - Turmas 2012 e Turma 2 de 2013..................... 70

Tabela 4.3: Recursos de ensino-aprendizagem usados em sala de aula.......................... 73

Tabela 4.4: Comentários de alunos da Turma 2 - 2013 sobre o formato da disciplina. 81

Tabela 4.5: Comentários de alunos da Turma 2 - 2013 sobre o tempo dedicado às tarefas da disciplina de Planejamento e Análise de Sistemas de Transportes. 84

Tabela 4.6: Comentários de alunos da Turma 2 - 2013 sobre o TIDIA-Ae 86 Tabela 4.7: Comentários de alunos da Turma 2 - 2013 sobre o meio de interação favorito nas atividades da disciplina.

Tabela 4.8: Comentários de alunos da Turma 2 - 2013 sobre a atividade de aprendizagem ativa.

Tabela 4.9: Comentários de alunos da Turma 2 - 2013 sobre a dificuldade para confecção de mapas conceituais. 106

Tabela 4.10: Comentários de alunos da Turma 2 - 2013 sobre a maior dificuldade para confecção de mapas conceituais. 108

Tabela 4.11: Comentários de alunos da Turma 2 - 2013 sobre uso dos mapas conceituais como ferramenta de avaliação. 109

Tabela 4.12: Comentários de alunos da Turma 2 - 2013 sobre uso dos mapas conceituais como representação da média final na disciplina. 110

Tabela 4.13: Comentários de alunos da Turma 2 - 2013 sobre outros usos dos mapas conceituais nas atividades do curso de Engenharia Civil. 111

Tabela 4.14: Número de comentários apresentados por aluno. 112

Tabela 4.15: Áreas de conhecimento relativas à Engenharia de Transportes, conforme a revisão da literatura 115 



\section{SUMÁRIO}

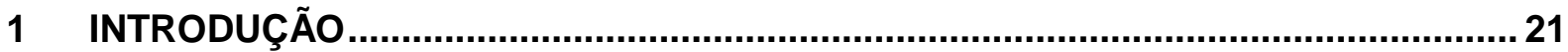

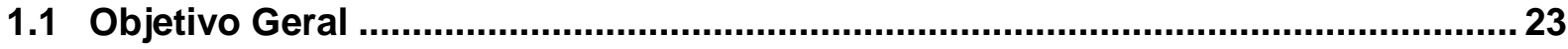

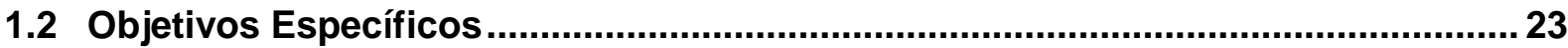

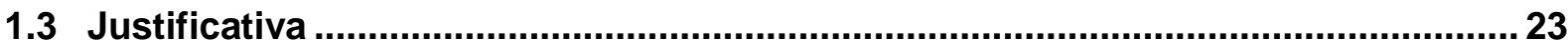

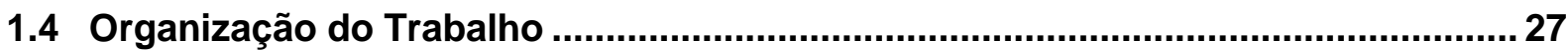

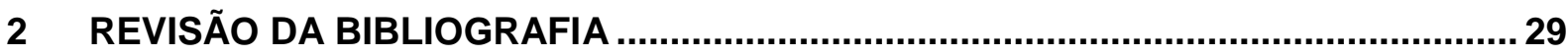

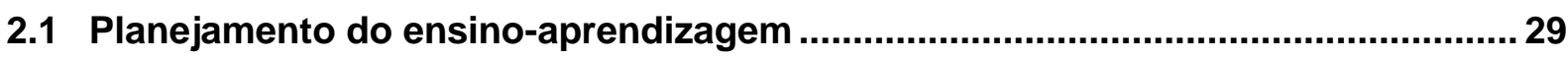

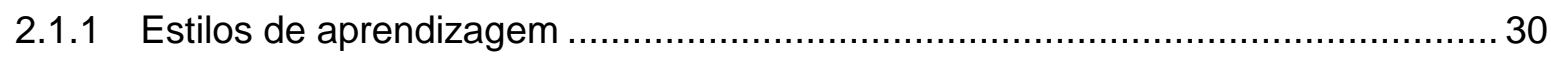

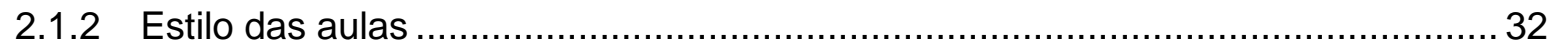

2.1.3 Classificador de temperamentos: Keirsey e Bates......................................... 35

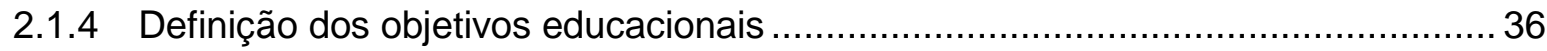

2.2 Especificação dos métodos e técnicas de ensino-aprendizagem ............................38

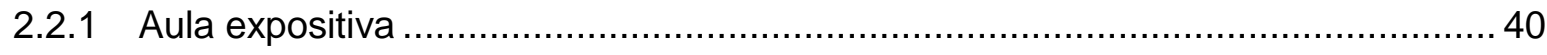

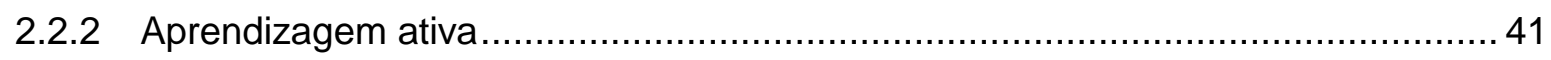

2.3 Avaliação do ensino-aprendizagem - Avaliação do produto ................................46

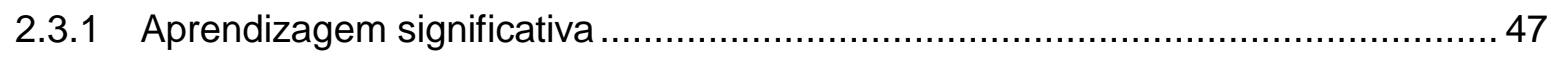

2.3.2 Diferenciação progressiva e reconciliação integrativa ......................................... 49

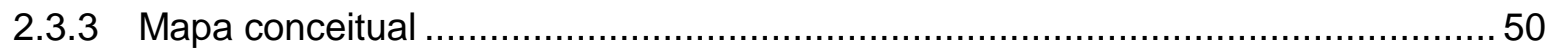

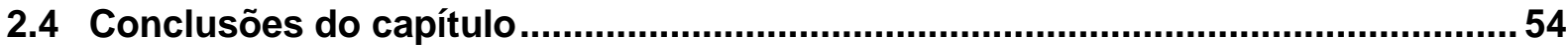

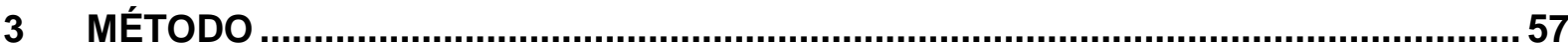

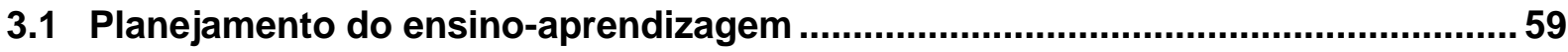

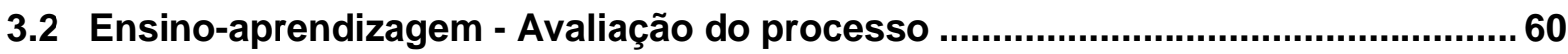

3.2.1 Recursos de ensino-aprendizagem em sala de aula .....................................60

3.2.2 Caracterização dos estilos das aulas ......................................................... 60

3.2.3 Aprendizagem ativa - Metodologia da problematização .................................... 61

3.3 Ensino-aprendizagem - Avaliação do Produto......................................................61

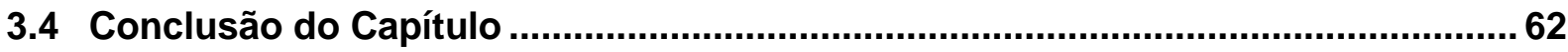

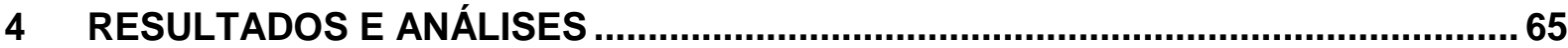

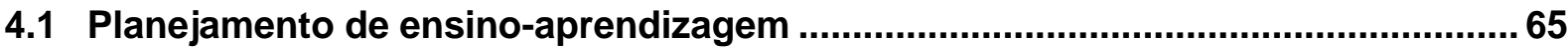

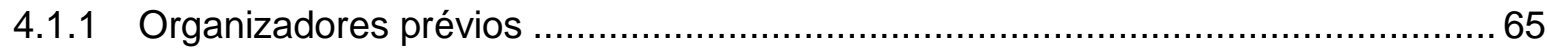

4.1.2 ILS - Preferências de aprendizagem ....................................................... 66

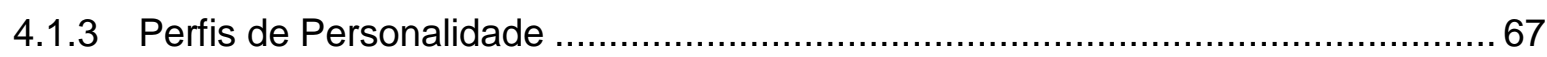

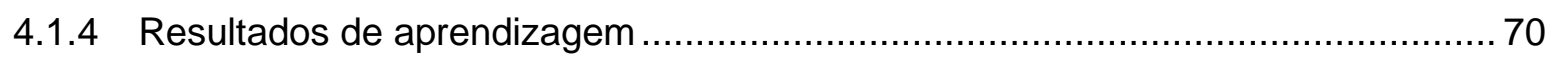

4.2 Ensino-aprendizagem - Avaliação do processo ................................................ 72 
4.2.1 Recursos de ensino-aprendizagem em sala de aula

4.2.2 Caracterização dos estilos das aulas x preferências de aprendizagem dos alunos

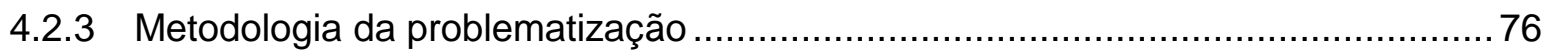

4.2.3.1 Análise da percepção da Turma de 2012 e Turma 2 de 2013 em relação a disciplina e suas abordagens............................................................93

4.3 Ensino-aprendizagem - Avaliação do produto: mapas conceituais ........................ 98

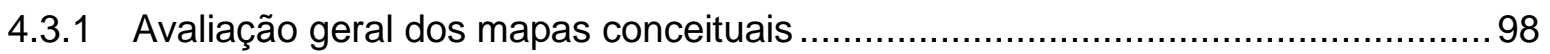

4.3.1.1 Avaliação dos mapas conceituais - Turma de 2012 …............................99

4.3.1.2 Avaliação dos mapas conceituais - Turma 1 de 2013 ............................. 100

4.3.1.3 Avaliação dos mapas conceituais - Turma 2 de 2013 ........................... 102

4.3.1.4 Percepção dos alunos da Turma 2 de 2013 sobre os mapas conceituais 104

4.3.1.5 Abordagem geral sobre os mapas conceituais 113

4.4 Proposta de Regime Integrado de Estudos Especiais em Engenharia de Transportes. 114

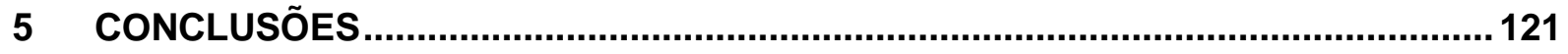

6 SUGESTÕES PARA TRABALHOS FUTUROS..................................................125

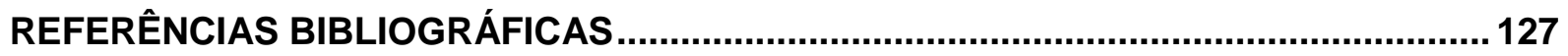

ANEXO A. INVENTÁRIO DOS ESTILOS DE APRENDIZAGEM..................................133

ANEXO B. INVENTÁRIO CLASSIFICADOR DE TEMPERAMENTOS ............................139

ANEXO C. QUESTIONÁRIO ONLINE PARA OBTER A PERCEPÇÃO DOS ALUNOS

EM RELAÇÃO À DISCIPLINA ...................................................................... 145

ANEXO D. INSTRUMENTO PARA OBTER O ESTILO DAS AULAS ..............................151

ANEXO E. TURMAS QUE PARTICIPARAM DOS EXPERIMENTOS .............................153

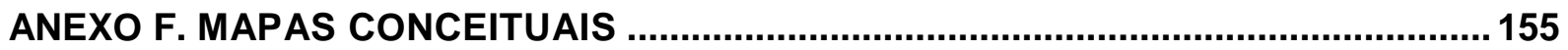

ANEXO G. COMENTÁRIOS FEITOS PELOS ALUNOS NO QUESTIONÁRIO ONLINE -

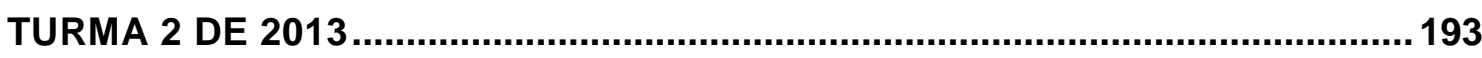




\section{INTRODUÇÃO}

A educação em engenharia vem passando, de forma geral, por uma série de transformações. Apesar de muitas destas mudanças estarem ligadas a processos mais gerais (como a globalização, por exemplo), do ponto de vista do ambiente de ensino o impacto é mais visível na sala de aula. Tendo em vista que a maior parte da educação formal de engenheiros tradicionalmente se dá em sala de aula, alterar esse ambiente significa mudar estruturas consagradas por décadas de uso e acomodação. Porém, é preciso iniciar o processo de mudança e tentar, de alguma forma, melhorar ou adaptar a formação de engenheiros, já que as demandas da sociedade precisam ser atendidas não apenas sob o ponto de vista quantitativo, mas também sob um olhar crítico, criativo e fundamentado em conceitos de qualidade. Em função do exposto, o processo de formação de engenheiros para atuarem no planejamento de transportes e da mobilidade deveria ser feito de forma diferenciada do que é praticado atualmente, no tocante a competências e habilidades.

No atual contexto no Brasil, os profissionais que atuam na área de Engenharia de Transportes são oriundos geralmente dos cursos de graduação em Engenharia Civil e Arquitetura e Urbanismo. Outros obtiveram formação em cursos de pós-graduação Lato Sensu e/ou Stricto Sensu. Porém o maior contingente de profissionais da área de Engenharia de Transportes ainda é oriundo dos cursos de graduação em Engenharia Civil. A Engenharia Civil faz parte do escopo que compreende a amplitude de conhecimentos da Engenharia de Transportes, conforme destacado por Khisty e Lall (2003), conforme a Figura 1.1. Nesta figura fica nítido que os conhecimentos necessários para a atuação do profissional de Engenharia de Transportes são abrangentes e envolvem diversas áreas. De maneira geral, no entanto, os cursos de Engenharia Civil têm seus programas de ensino voltados para conhecimentos técnicos gerais da construção civil. Isto foi destacado por Silva Junior e Rodrigues da Silva (2012), ao ressaltar a questão da pouca carga horária disponível à Engenharia de Transportes, sobretudo Planejamento de Transportes, em cursos de Engenharia Civil. A solução para este problema pode ser uma abordagem diferenciada em termos de estrutura curricular. Uma alternativa seria a criação de cursos inteiramente dedicados à área. Esta pode ser, porém, onerosa, demorada e muitas vezes ficar paralisada por questões burocráticas.

Outra abordagem, que se apresenta hoje como alternativa para a formação ao nível de graduação em cursos de Engenharia Civil, Produção e áreas afins (ver Figura 1.1), seria 
aquilo que se denomina como Regime de Estudos Especiais. Este aproveita a infraestrutura, o corpo docente e demais aspectos já disponíveis, o que contribui para vencer questões burocráticas e orçamentárias que envolvem a criação de novos cursos. Neste caso, a formação do estudante ainda tem o foco original da área escolhida (Engenharia Civil, de Produção etc.), mas é complementada por um conjunto de disciplinas optativas de uma área específica (Transportes, Geotecnia, etc.). Uma vez obtido um número mínimo de créditos predefinido nestas disciplinas optativas, o estudante faz jus a um certificado adicional na área escolhida (além do diploma de Engenheiro Civil, por exemplo). No caso de transportes, no entanto, a hipótese aqui admitida é que não basta a oferta de disciplinas com tópicos da área, se feita de forma tradicional. É preciso valorizar uma formação mais abrangente, contemplando competências e habilidades nestas disciplinas.

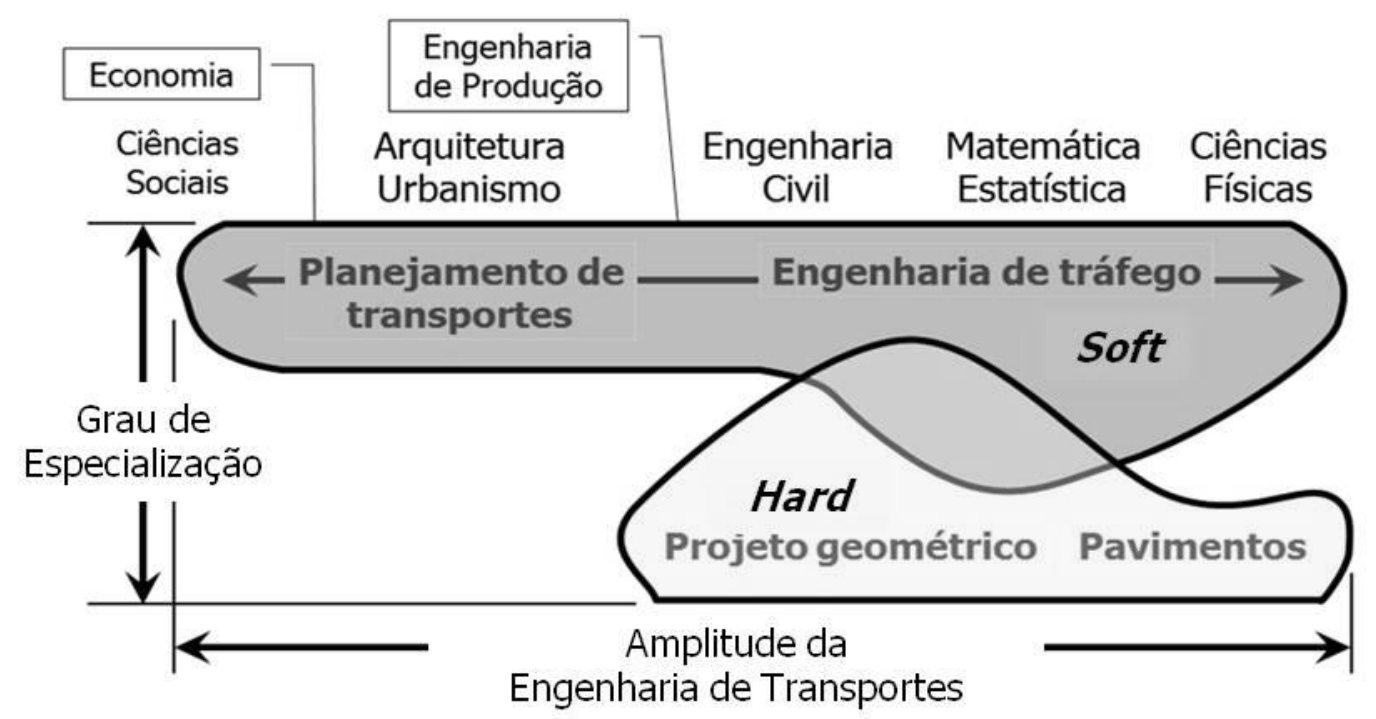

Figura 1.1: Interdisciplinaridade da Engenharia de Transportes Fonte: Khisty e Lall (2003)

Em síntese, a formação de profissionais na área de Engenharia de Transportes ao nível de graduação pode se dar pelo menos de três maneiras: através de cursos completos; através de disciplinas isoladas com foco na área de transportes (forma hoje encontrada na maioria das universidades brasileiras, conforme observado por Silva Junior e Rodrigues da Silva, 2011) e através de um Regime de Estudos Especiais. Qualquer uma destas abordagens exigiria pelo menos dois cuidados. Primeiro, a definição de um conjunto de disciplinas que cubra as principais áreas de conhecimento da Engenharia de Transportes (e/ou Mobilidade). Segundo, a definição da(s) estratégia(s) de ensino-aprendizagem a serem adotadas nestas disciplinas. Este trabalho se concentra no segundo aspecto, com a perspectiva da sua aplicação em um regime de formação de estudos especiais em Engenharia de Transportes. A investigação envolveu questões relativas ao planejamento, avaliação do processo e 
avaliação do produto das ações de ensino-aprendizagem. Para isto foram desenvolvidos estudos em uma disciplina que trata de Planejamento e Análise de Sistemas de Transportes.

\subsection{Objetivo Geral}

Introduzir, monitorar e avaliar alterações em uma abordagem pedagógica que mescla aulas expositivas e aprendizagem ativa, concebida com o propósito de ampliar competências e habilidades de alunos de graduação para a área de Engenharia de Transportes.

\subsection{Objetivos Específicos}

- Planejar o processo de ensino-aprendizagem por meio de objetivos educacionais para uma disciplina relacionada ao planejamento de transportes;

- Caracterizar uma amostra de alunos em termos de preferências de aprendizagem e perfis de personalidade;

- Garantir o alinhamento dos procedimentos de ensino-aprendizagem (recursos usados em sala de aula, estilo das aulas do professor e percepção dos alunos em relação à atividade de aprendizagem ativa) com as características da amostra de alunos;

- Combinar aulas expositivas e técnicas de aprendizagem ativa, com foco sobre tudo na resolução de problemas, para ampliar competências e habilidades de domínio conceitual;

- Avaliar a aprendizagem por meio de uma estratégia que combina provas tradicionais e mapas conceituais, conforme a teoria da Aprendizagem Significativa.

- Propor um regime integrado de estudos especiais em Engenharia de Transportes com base nos resultados obtidos.

\subsection{Justificativa}

O processo de ensino-aprendizagem em nível de graduação em engenharia tem sido alvo de grande preocupação por parte de profissionais e educadores. Existe a necessidade de alterações no processo de formação dos engenheiros, dado que usualmente os projetos pedagógicos dos cursos de engenharia são exclusivamente tradicionais. Não existe integração entre os componentes curriculares, há pouca correlação entre teoria e prática e a inserção no ambiente profissional é feita de forma tardia (Escrivão Filho e Ribeiro, 2009). 
O grande desafio é implantar formas mais dinâmicas de ensino-aprendizagem, amparadas numa estrutura multidisciplinar, ativas e de formação contínua, segundo Silvestre et al. (2010). O ensino não poderá estar direcionado apenas pelos conteúdos, mas também pelos objetivos educacionais. Estes objetivos deverão conduzir ao desenvolvimento das competências necessárias para o enfrentamento dos problemas relativos à engenharia.

Kyte et al. (2010) salientam que as habilidades pretendidas nos estudantes devem ser função da natureza ampla e multidisciplinar dos problemas de engenharia. O objetivo das instituições de ensino deveria ser conduzir os estudantes a níveis elevados de processos cognitivos e conhecimento baseado em dimensões taxonômicas. Para Alvarstein e Johannesen (2001) é preciso aplicar métodos de ensino que permitam aos estudantes serem mais ativos na busca dos seus próprios conhecimentos. Desta forma, o processo de formação deveria ser conduzido por técnicas de ensino-aprendizagem ativas ou que tivessem uma abordagem diferenciada. Neste caso, o estudante passaria a ser também responsável pela construção do seu próprio conhecimento. As atividades conduziriam ao desenvolvimento de habilidades para atuar em um ambiente interdisciplinar e mais interativo.

Com relação à Engenharia de Transportes, uma das realidades que tem forte impacto na qualidade de vida da população é a questão da formação de profissionais para atuarem em questões relativas aos transportes e a mobilidade urbana. Rodrigues da Silva et al. (2010) destacam que os problemas relacionados à mobilidade urbana variam de país para país e que tem havido algumas mudanças na forma como as cidades planejam seus sistemas de circulação.

Outra questão é com relação aos cursos de Graduação em Engenharia Civil, principais formadores de recursos humanos para atuarem em empresas e organismos das diversas esferas de governo junto aos problemas relativos a transporte e mobilidade. Estes cursos, na grande maioria dos casos, não possuem em sua estrutura curricular métodos de ensino voltados para a aquisição de habilidades que possam garantir desenvoltura para trabalho em equipe, liderança, senso crítico e análise de questões socioeconômicas e/ou ambientais ou sustentabilidade.

Conforme já apresentado na Figura 1.1 a Engenharia Civil faz parte do escopo de conhecimentos que compreende a Engenharia de Transportes. Mas também fica nítido que os conhecimentos necessários para a atuação do profissional de Engenharia de Transportes 
são muito abrangentes e envolvem áreas como: Economia; Geografia; Ciências Sociais; Arquitetura e Urbanismo; Matemática e Estatística; Ciências Físicas e Engenharia de Produção.

Todas essas áreas relacionadas à Engenharia de Transportes precisam ser abordadas no processo de formação do Engenheiro de Transportes. Porém os cursos de Engenharia Civil não possuem carga horária suficiente para tratar da magnitude desses temas. Uma vez que geralmente estes cursos têm seus programas de ensino voltados para conhecimentos técnicos da construção civil.

Ao abordarem questões relativas ao planejamento do processo de ensino-aprendizagem para a formação de profissionais para atuarem em Engenharia de Transportes, Silva Junior e Rodrigues da Silva (2012) ressaltam a questão da pouca carga horária disponível à Engenharia de Transportes em cursos de Engenharia Civil, de acordo com a Tabela 1.1.

Conforme pode ser observada na Tabela 1.1, a carga horária dedicada aos conhecimentos relativos à Engenharia de Transportes é relativamente menor se comparada com as áreas de estruturas e construção civil por exemplo. Ainda segundo estes autores a clássica divisão entre Planejamento e Operação de Sistemas de Transportes e Infraestrutura de Transportes foi considerada para contabilizar as percentagens de carga horária na Tabela 1.1. Os dados foram obtidos no segundo semestre de 2010, com base em informações online disponíveis nos sites das universidades pesquisadas. Em alguns casos, na época do levantamento, algumas universidades só apresentaram carga horária na área de transportes porque possuíam disciplinas voltadas exclusivamente à infraestrutura de transportes, tais como: estradas; projeto geométrico; dimensionamento de pavimentos; etc.

Em um estudo para analisar o nível de ensino-aprendizagem em disciplinas de transporte sustentável, J Wua et al. (2013) investigaram informações de aproximadamente 5.000 instituições na Europa e Estados Unidos e apresentaram as seguintes conclusões: i) a maioria das disciplinas eram de três créditos; ii) as disciplinas eram mais ofertadas a estudantes de pós-graduação do que a estudantes de graduação; o método de ensino mais adotado foi o uso de aulas expositivas; iii) as disciplinas sobre transportes sustentáveis são mais oferecidas nos Estados Unidos do que na Europa; e iv) os conteúdos das disciplinas estão mais alinhados com questões ambientais do que com questões econômicas e sociais no atual contexto dos transportes sustentáveis. 
Tabela 1.1- Carga horária percentual das áreas em cursos de Engenharia Civil no Brasil

\begin{tabular}{|c|c|c|c|c|c|c|c|c|c|}
\hline \multirow[t]{2}{*}{ IES } & \multirow{2}{*}{$\begin{array}{c}\text { Disciplinas } \\
\text { Gerais } \\
\%\end{array}$} & \multirow{2}{*}{$\begin{array}{c}\text { Estruturas } \\
\%\end{array}$} & \multirow{2}{*}{$\begin{array}{c}\text { Construção } \\
\text { Civil } \\
\%\end{array}$} & \multirow{2}{*}{$\begin{array}{c}\text { Hidráulica, } \\
\text { Saneamento e } \\
\text { Meio } \\
\text { Ambiente } \\
\% \\
\end{array}$} & \multirow{2}{*}{$\begin{array}{c}\text { Geotecnia } \\
\%\end{array}$} & \multicolumn{3}{|c|}{ Transportes } & \multirow{2}{*}{ Região } \\
\hline & & & & & & Infra & Planej & Total & \\
\hline EESC/USP & 22,95 & 20,66 & 16,72 & 17,70 & 11,15 & 6,99 & 6,58 & 13,57 & Sudeste \\
\hline UNESP/Bauru & 36,69 & 19,76 & 12,90 & 13,71 & 8,06 & 5,32 & 3,55 & 8,87 & Sudeste \\
\hline UFRJ & 48,57 & 16,67 & 15,24 & 8,57 & 6,19 & 1,91 & 2,85 & 4,76 & Sudeste \\
\hline UFC & 40,80 & 20,11 & 13,22 & 13,79 & 4,60 & 4,03 & 3,44 & 7,47 & Nordeste \\
\hline UFPA & 31,48 & 14,81 & 22,22 & 11,11 & 9,26 & 6,11 & 5,00 & 11,11 & Norte \\
\hline UFRGS & 46,35 & 10,30 & 15,45 & 14,16 & 7,73 & 2,14 & 3,87 & 6,01 & Sul \\
\hline UFSC & 19,35 & 16,77 & 32,90 & 8,39 & 9,68 & 8,38 & 4,52 & 12,90 & Sul \\
\hline UNICAMP & 37,05 & 16,33 & 16,33 & 13,15 & 8,37 & 5,26 & 3,5 & 8,76 & Sudeste \\
\hline UFRR & 50,67 & 17,94 & 13,45 & 5,38 & 8,97 & 0,77 & 2,82 & 3,59 & Norte \\
\hline UFAL & 40,00 & 9,57 & 20,00 & 15,65 & 9,57 & 2,01 & 3,21 & 5,22 & Nordeste \\
\hline UFPE & 41,56 & 13,42 & 18,18 & 11,26 & 8,66 & 3,70 & 3,23 & 6,93 & Nordeste \\
\hline UFRN & 37,71 & 15,25 & 19,92 & 10,59 & 8,47 & 5,23 & 2,82 & 8,05 & Nordeste \\
\hline UFPR & 30,00 & 14,55 & 20,91 & 19,09 & 8,18 & 4,36 & 2,91 & 7,27 & Sul \\
\hline UEPG & 32,70 & 16,73 & 23,19 & 12,17 & 5,32 & 6,43 & 3,46 & 9,89 & Sul \\
\hline UEL & 28,06 & 20,55 & 23,72 & 15,02 & 7,91 & 3,56 & 1,18 & 4,74 & Sul \\
\hline UEM & 36,03 & 13,36 & 17,41 & 17,81 & 7,29 & 4,05 & 4,05 & 8,10 & Sul \\
\hline UNIOESTE & 34,53 & 18,83 & 22,42 & 11,66 & 7,17 & 4,04 & 1,34 & 5,38 & Sul \\
\hline UFSM & 38,50 & 18,14 & 14,16 & 14,16 & 7,08 & 5,17 & 2,79 & 7,96 & Sul \\
\hline UDESC & 46,30 & 16,57 & 21,93 & 8,85 & 2,44 & 2,15 & 1,75 & 3,90 & Sul \\
\hline UFMT & 40,30 & 17,91 & 19,40 & 10,45 & 5,97 & 3,88 & 2,09 & 5,97 & Centro-Oeste \\
\hline UFMS & 37,82 & 18,49 & 23,11 & 8,40 & 7,56 & 3,00 & 1,62 & 4,62 & Centro-Oeste \\
\hline UFG & 39,47 & 13,16 & 25,44 & 9,65 & 7,89 & 2,41 & 1,98 & 4,39 & Centro-Oeste \\
\hline UEG-Anápolis & 32,99 & 16,49 & 29,90 & 9,62 & 5,50 & 3,85 & 1,65 & 5,50 & Centro-Oeste \\
\hline UFBA & 42,11 & 17,54 & 22,81 & 7,02 & 7,02 & 3,51 & 0 & 3,51 & Nordeste \\
\hline UFTM & 46,92 & 16,15 & 16,92 & 6,92 & 6,92 & 3,38 & 2,77 & 6,15 & Sudeste \\
\hline \multirow[t]{3}{*}{ UFOP } & 41,92 & 18,78 & 16,16 & 8,73 & 8,73 & 3,69 & 1,99 & 5,68 & Sudeste \\
\hline & \multicolumn{9}{|c|}{ Maior carga horária } \\
\hline & \multicolumn{9}{|c|}{ Menor carga horária } \\
\hline
\end{tabular}

Conforme apresentado anteriormente, os problemas de formação de engenheiros para atuarem em questões relativas aos sistemas de transportes é muito mais abrangente e não fica restrito ao Brasil. Nos Estados Unidos e alguns países Europeus de língua inglesa há também a falta de cursos, métodos de ensino-aprendizagem e disciplinas que possam preparar melhor os futuros engenheiros de transportes.

Fica claro que a formação de profissionais para atuarem na região denominada soft, conforme a Figura 1.1, da Engenharia de Transportes pode estar sendo subdimensionada nos projetos pedagógicos das instituições. Pois, na maioria das vezes, os conhecimentos que compreenderiam o planejamento dos transportes ficam a cargo das disciplinas optativas. 
Desta forma, a execução de estudos que abordem a questão da formação de profissionais, em nível de graduação em engenharia, para atuarem junto aos problemas de transportes e mobilidade, torna-se necessária e justificada. Existem indicativos de que a população cada vez mais irá viver em áreas urbanas. Isso aumentará a demanda por diversos serviços oferecidos nas cidades brasileiras, dentre eles o setor de transporte e mobilidade.

\subsection{Organização do Trabalho}

O texto encontra-se dividido em cinco capítulos, com a seguinte distribuição:

Capítulo 1 - É a parte introdutória, onde estão o objetivo geral e a justificativa do trabalho;

Capítulo 2 - Contém a revisão bibliográfica, que apresenta os conceitos que serviram de base para a metodologia aplicada nesta pesquisa;

Capítulo 3 - É apresentada a metodologia de pesquisa, feita a descrição das etapas e a forma de atuação durante o processo de investigação;

Capítulo 4 - Neste capítulo são apresentados os resultados e feitas algumas considerações sobre os mesmos;

Capítulo 5 - São apresentadas as conclusões baseadas nos resultados obtidos. 


\section{REVISÃO DA BIBLIOGRAFIA}

O ensino-aprendizagem em cursos de engenharia deveria envolver basicamente três etapas: i) a definição de objetivos educacionais alinhados com os conteúdos, competências e habilidades esperadas dos aprendizes, bem como caracterizar as preferências de aprendizagem e os perfis de personalidade dos estudantes; ii) especificação dos métodos e técnicas de ensino-aprendizagem; e iii) avaliação do ensino-aprendizagem ou avaliação do produto de ensino-aprendizagem. Enquanto a primeira etapa deve ser conduzida na fase de planejamento das atividades de ensino-aprendizagem, na segunda etapa ocorre o desenvolvimento do processo de ensino-aprendizagem. Também nesta fase pode ser conduzida a avaliação do processo. Já a terceira etapa é o momento em que devem ser aplicados os mecanismos que possam atestar se os resultados de aprendizagem pretendidos foram alcançados, foco principal deste trabalho. A seguir são apresentados alguns conceitos relacionados a estas três etapas da formação dos profissionais de engenharia na atualidade.

\subsection{Planejamento do ensino-aprendizagem}

O planejamento do ensino deveria envolver uma série de atividades pré-classe. Deveriam ser utilizados mecanismos que pudessem identificar qual a melhor ou mais adequada forma de conduzir um determinado assunto para um determinado grupo de estudantes. Cabe ressaltar que este processo precisaria ser dinâmico e reconhecido como importante tanto por alunos quanto por professores.

De um modo geral, os professores estão muito preocupados com o que vão ensinar. Esta é uma questão importante, desde que os alunos não sejam esquecidos neste processo. Uma forma de ensinar é aprender como e porque os alunos aprendem. Está cada vez mais claro que o indivíduo estuda e reconstrói o conhecimento baseado em características e interesses profissionais. Desta forma, a metacognição passa a ter uma presença marcante no processo de ensino-aprendizagem, nas atividades de pesquisa e discussões sobre o ensino superior (Krasilchik, 2008).

Ainda segundo Krasilchik (2008), a etapa mais elevada na hierarquia de objetivos educacionais sugere que os estudantes façam os seguintes questionamentos: Como aprendo? Quando sei que estou aprendendo? Qual auxílio eu devo procurar para alcançar minhas metas? Entendi ou li o que ouvi? Como alterar meu plano de estudo se não estiver 
trazendo os resultados que desejo? Desta forma, estimular esta etapa por meio de atividades de ensino-aprendizagem deveria fazer parte do planejamento do professor.

O planejamento do ensino deve iniciar com a análise de conteúdo. Nesta análise buscam-se as relações gerais básicas, essenciais e que dão suporte ao conteúdo. Formula-se um conceito nuclear que deve expressar o princípio interno do tema a ser estudado. Este princípio interno se caracteriza pela relação geral entre os vários elementos que constituem um objeto de estudo (Libâneo, 2009).

Muitas pesquisas sobre o planejamento das atividades já foram conduzidas, deixando evidente que esta etapa de preparação das atividades é muito importante. Felder e Silverman (1988) afirmam que o desempenho de um estudante em relação a um determinado conteúdo possui relação direta com suas habilidades naturais e preparo anterior, bem como deve existir compatibilidade entre o seu estilo de aprendizagem e o estilo de ensino do professor. Desta forma, se houver possíveis incompatibilidades de estilos, uma série de consequências negativas pode acontecer, tanto relativas aos alunos quanto aos professores. Segundo Kuri (2004), compreender os tipos de personalidade ou estilos de aprendizagem auxiliaria a entender as diferenças existentes entre os alunos de uma mesma classe. Desta forma, o professor poderia promover um processo de ensinoaprendizagem mais direcionado às expectativas dos estudantes e talvez tornar a formação mais eficaz e duradoura.

Sobre a questão da eficácia e retenção dos conhecimentos apresentados a um grupo de alunos e sobre o preparo anterior, Moreira e Masini (1982), ao se referirem à teoria da Aprendizagem Significativa de David Ausubel, salientam que a ideia central desta teoria é a de que o fator isolado mais importante que pode influenciar a aprendizagem é aquilo que o estudante já sabe sobre um determinado tema.

\subsubsection{Estilos de aprendizagem}

Existem inúmeros modelos ou mecanismos que podem caracterizar as preferências de aprendizagem de indivíduos. Segundo Pereira (2005), estes modelos vêm sendo desenvolvidos com o objetivo de tentar explicar como são os processos que geram aprendizado e identificar como as pessoas percebem e processam informações e experiências. Entre os modelos mais estudados e citados na atualidade podem ser destacados o modelo de Felder e Silverman (1988) e o modelo de Kolb (1984). Neste 
estudo fez-se uso apenas do modelo desenvolvido por Felder e Silverman (1988), na forma do ILS - Index of Learning Styles, desenvolvido por Felder e Soloman (2004).

O conhecimento dos estilos de aprendizagem pode ser uma ferramenta eficiente para o planejamento de atividades a serem conduzidas em sala de aula em disciplinas da área de Engenharia de Transportes, que são lecionadas em cursos de Engenharia Civil. Segundo Felder e Spurlin (2005), os estilos de aprendizagem, ao serem utilizados para identificar as preferências de aprendizagem dos estudantes, possibilitam a construção de estratégias ou mecanismos instrucionais mais eficazes e direcionados aos estudantes ou grupos de estudantes.

Segundo Felder e Silverman (1988), o processo de aprendizagem caracteriza-se por duas fases: recepção e tratamento de uma determinada informação. Durante a recepção ocorre um processo simultâneo de processamento da informação externa, que é captada pelo estudante por meio dos sentidos, e das informações que o estudante já possuía ou que surgem de forma introspectiva sobre um determinado assunto. Já o tratamento está mais relacionado à forma como o estudante irá continuar trabalhando, em uma atividade de ensino, a informação ou conhecimento apresentado, ou seja, armazenar, refletir, aplicar, etc.

Vale ressaltar neste item uma diferenciação importante para evitar possíveis confusões relativas ao modelo de estilo de aprendizagem apresentado por Felder e Silverman (1988) e o ILS - Index of Learning Styles desenvolvido por Felder e Soloman (2004). No modelo são apresentadas as dimensões relativas às formas como os aprendizes recebem e tratam as informações. No ILS é apresentado um mecanismo para obtenção do índice de estilos de aprendizagem, ou seja, as preferências de aprendizagem de um indivíduo ou grupo de indivíduos.

O ILS contempla quatro das cinco dimensões presentes no modelo apresentado por Felder e Silverman (1988). Estas dimensões formam uma espécie de pares opostos em termos de estilo e possuem intensidade que pode ser visualizada em uma escala numérica (ver Figura 2.1). As quatro dimensões que fazem parte do índice são: dimensão processamento (estilos ativo/reflexivo - AT/RF); dimensão percepção (estilos sensorial/intuitivo - SE/IN); dimensão entrada-input (estilos visual/verbal - VS/VB) e dimensão compreensão (estilos sequencial/global - SQ/GLO). 


\begin{tabular}{|c|c|c|c|c|c|c|c|c|c|c|c|}
\hline \multicolumn{6}{|c|}{ Ativo } & \multicolumn{6}{|c|}{ Reflexivo } \\
\hline 11 & 9 & 7 & 5 & 3 & 1 & 1 & 3 & 5 & 7 & 9 & 11 \\
\hline \multicolumn{6}{|c|}{ a } & \multicolumn{6}{|c|}{ b } \\
\hline
\end{tabular}

\begin{tabular}{|c|c|c|c|c|c|c|c|c|c|c|c|}
\hline \multicolumn{3}{|c|}{ Sensorial } & \multicolumn{6}{c|}{ Intuitivo } \\
\hline \hline 11 & 9 & 7 & 5 & 3 & 1 & 1 & 3 & 5 & 7 & 9 & 11 \\
\hline \hline & a & \multicolumn{5}{c|}{ b } \\
\hline
\end{tabular}

\begin{tabular}{|c|c|c|c|c|c|c|c|c|c|c|c|}
\hline \multicolumn{3}{|c|}{ Visual } & \multicolumn{7}{c|}{ Verbal } \\
\hline 11 & 9 & 7 & 5 & 3 & 1 & 1 & 3 & 5 & 7 & 9 & 11 \\
\hline \hline \multicolumn{3}{|c|}{ a } & \multicolumn{7}{|c|}{ b } \\
\hline
\end{tabular}

\begin{tabular}{|c|c|c|c|c|c|c|c|c|c|c|c|}
\hline \multicolumn{3}{|c|}{ Sequencial } & \multicolumn{6}{c|}{ Global } \\
\hline \hline 11 & 9 & 7 & 5 & 3 & 1 & 1 & 3 & 5 & 7 & 9 & 11 \\
\hline \hline \multicolumn{3}{|c|}{ a } & \multicolumn{5}{|c|}{ b } \\
\hline
\end{tabular}

\begin{tabular}{|l|c|c|c|c|c|}
\hline Forte & Moderado & Equilíbrio & Equilíbrio & Moderado & Forte \\
\hline
\end{tabular}

Figura 2.1: Representação esquemática da escala do índice de estilo de aprendizagem de Felder e Soloman (2004)

O ILS é um instrumento na forma de questionário, que é composto por 44 sentenças. Este questionário deve ser respondido pelo indivíduo que terá suas preferências de aprendizagem identificadas. As questões possuem alternativas a e b e cada dimensão do índice possui 11 sentenças. Ao finalizar o questionário é feito o processamento para gerar o resultado por dimensão. Este resultado é obtido pela diferença entre a soma das respostas $a$ ou $b$, do questionário, para cada dimensão. Em seguida os resultados por dimensão são posicionados em uma escala, conforme a Figura 2.1.

\subsubsection{Estilo das aulas}

Os métodos de ensino adotados pelos professores deveriam estar de acordo com as preferências de aprendizagem dos estudantes. Planejar as atividades, conforme as preferências de aprendizagem, poderia aprimorar a formação e resultar em processos de ensino-aprendizagem mais eficazes e motivadores para os futuros engenheiros e maior satisfação aos professores. Segundo Piemolini-Barreto e Sandri (2011), de maneira geral não há preocupação com as preferências de aprendizagem do corpo discente em classe. 
Isto pode causar algumas insatisfações por parte de alunos e docentes em relação ao curso e às disciplinas cursadas pelos alunos.

O processo de ensino-aprendizagem é perene e dinâmico e tende a transformar-se conforme as mudanças ocorridas no ambiente que cerca o ser humano. Aprender e ensinar acontece a todo instante. As pessoas aprendem umas com as outras e ensinam umas às outras em diversos momentos ao longo da vida (Soares et al., 2012). Ao planejar atividades que estejam alinhadas com as preferências de aprendizagem dos alunos, o professor pode gerar uma motivação extra em sala de aula. Conforme relata Cury (2000), a oportunidade de conhecer seus estilos de aprendizagem foi valorizada pelos discentes, bem como o desenvolvimento de atividades que atendessem às suas preferências de aprendizagem. Ainda segundo a autora, o planejamento das atividades em geral favoreceu o clima de aprendizagem em classe e elevou a autoestima dos alunos.

Verificar o estilo das aulas das disciplinas pode ser uma importante estratégia para evitar incompatibilidades entre as preferências de aprendizagem dos alunos e o formato das aulas. Silva e Oliveira Neto (2010) investigaram, por meio de um questionário respondido pelos professores, os estilos das aulas de 40 disciplinas que faziam parte de um curso de graduação em contabilidade. Este questionário foi elaborado com base no modelo de Felder e Silverman (1988) de estilos de aprendizagem. Os resultados deste estudo permitiram obter o estilo das aulas sob a percepção do docente.

Silva Junior et al. (2013a) desenvolveram e testaram um instrumento para avaliar o estilo de ensino adotado por professores de um curso de Engenharia Civil. Segundo esses autores, o processo iniciou-se com a caracterização das preferências de aprendizagem de alunos e professores por meio do inventário de Felder e Soloman (2004). Em seguida foi aplicado um instrumento, conforme a Figura 2.2, desenvolvido a partir do inventário de Felder e Soloman (2004).

Os resultados permitiram a identificação de incompatibilidades entre as preferências de aprendizagem dos grupos envolvidos e as estratégias adotadas pelos docentes para o ensino. Estas incompatibilidades foram percebidas em todas as dimensões, o que destaca a importância da abordagem. O estudo demonstra que, junto com os estilos de aprendizagem dos alunos e instrutores, a identificação de estilos de ensino apresenta potencial para melhorar o processo ensino-aprendizagem (Silva Junior et al., 2013a). 

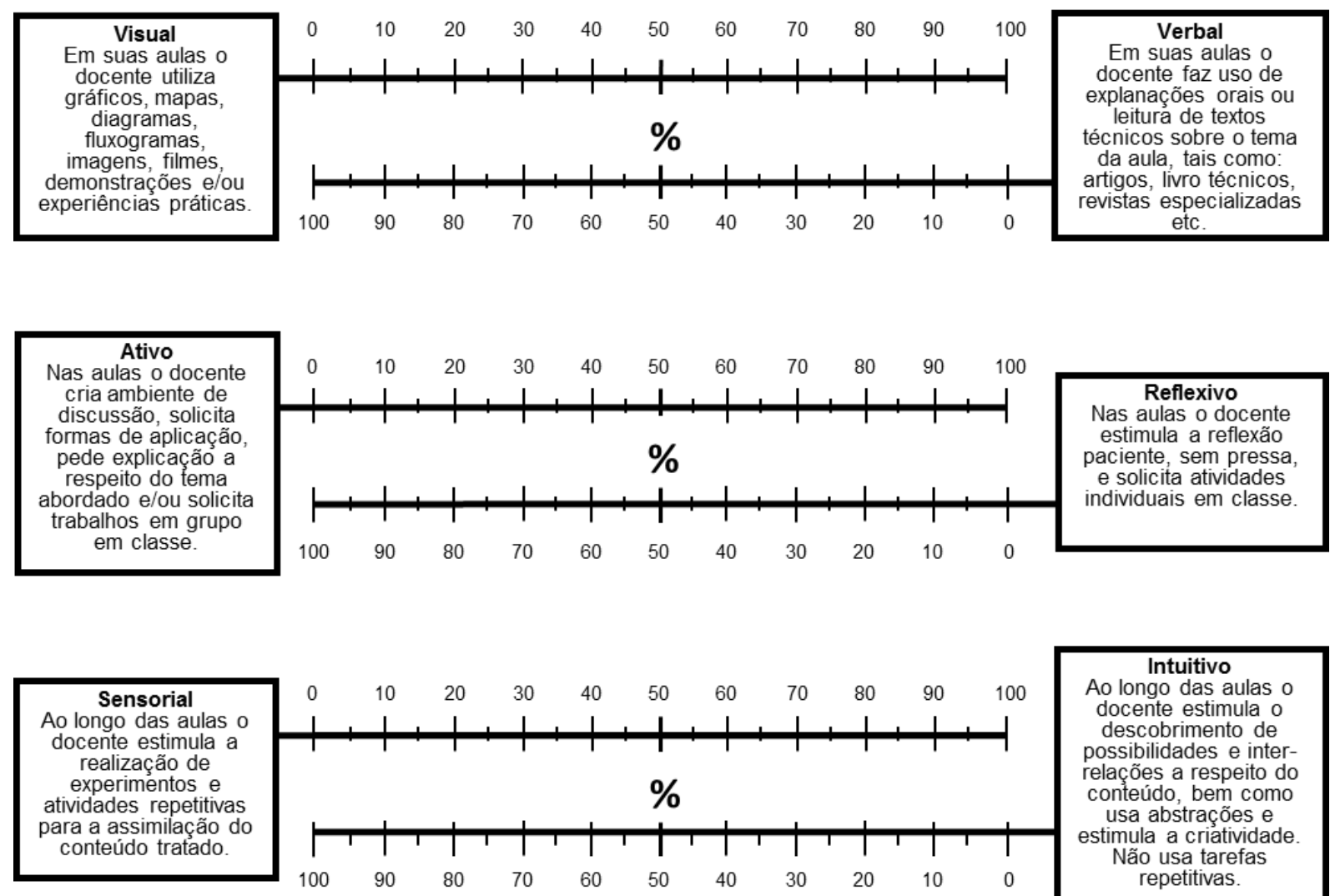

Intuitivo
Ao longo das aulas o
docente estimula o
descobrimento de
possibilidades e inter-
relações a respeito do
conteúdo, bem como
usa abstrações e
estimula a criatividade.
Não usa tarefas
repetitivas.
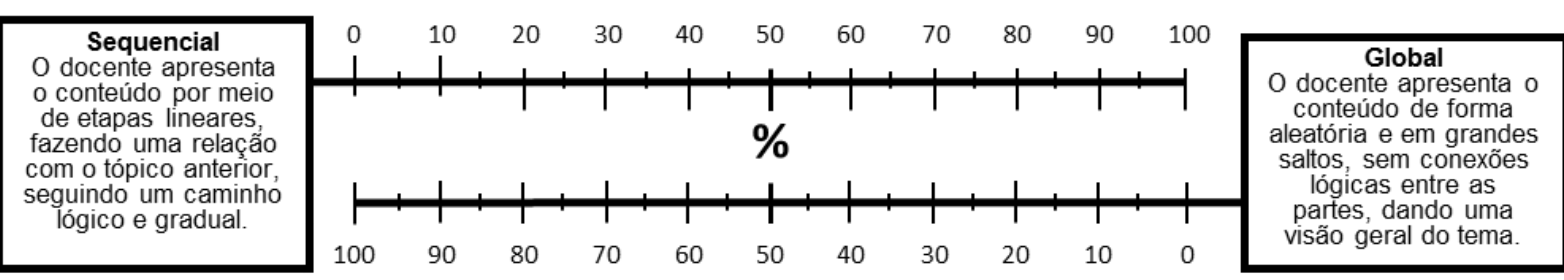

Figura 2.2: Instrumento para caracterizar o estilo das aulas - Desenvolvido por Silva Junior et al. (2013a)

A percepção dos alunos em relação às aulas apresentadas pelos professores é o ponto de partida para o uso do instrumento de identificação dos estilos das aulas. Ao final de um conjunto de aulas ou atividades de ensino, os alunos eram solicitados a especificar em qual dimensão, de acordo com a Figura 2.2, se encaixava aquele grupo de atividades de ensinoaprendizagem até aquele momento (Silva Junior et al., 2013a).

Vale ressaltar que ao especificar que um determinado grupo de atividades foi $70 \%$ visual, o aluno estava automaticamente considerando que o restante foi $30 \%$ verbal. Este mesmo procedimento deveria ser também adotado nas demais dimensões. Segundo Silva Junior et al. (2013a) os resultados relativos à percepção dos alunos eram comparados também com a percepção que o professor tinha sobre o mesmo grupo de atividades. Desta forma, sempre 
que os alunos utilizavam o instrumento, o professor também era solicitado a fazer a mesma operação de uso do instrumento de caracterização do estilo das aulas.

\subsubsection{Classificador de temperamentos: Keirsey e Bates}

$\mathrm{Na}$ abordagem de Keirsey e Bates (1984), o temperamento é fundamental para compreender as pessoas. Esta característica confere uma marca de identidade, que é semelhante a uma assinatura ou a uma impressão digital. Pode-se comparar a mente humana a um computador que tem no temperamento o seu hardware e no caráter o seu software. Sendo assim, o temperamento é uma forma inata da natureza humana e o caráter uma forma emergente, a qual se modifica por meio da interação de temperamento e ambiente (Kuri, 2004).

Keirsey e Bates introduziram algumas modificações em relação às ideias defendidas por Jung e por outros pesquisadores que se dedicaram ao estudo dos temperamentos (Kuri, 2004). Desta forma, Silva $(1992)^{1}$, citado em Kuri (2004), salienta que o principal aspecto diferenciador dos trabalhos de Keirsey e Bates em relação a Jung é que estes autores partem de quatro tipos de temperamentos básicos, que podem representar totalidades e não somatórias de funções. O indivíduo é de determinado subtipo não como consequência de uma combinação de função com atitude, mas a partir de um temperamento-base com algumas variações.

O Classificador de Temperamentos de Keirsey e Bates tem sido utilizado em muitos países, inclusive no Brasil, para identificar os tipos de personalidade e temperamento das pessoas e está apoiado na teoria dos tipos psicológicos de Jung (Colenci-Trevelin et al., 2008).

Segundo Kuri (2004), Keirsey e Bates consideram que cada personalidade é uma configuração única. Também enfatizam que cada indivíduo tende a avaliar os outros de acordo com sua própria imagem e semelhança e, quando os demais não se enquadram no seu esquema, sente-se frustrado e inconformado diante das divergências. Com base nisto, se o papel da educação é orientar o indivíduo para um conhecimento dinâmico do mundo, dos outros indivíduos e de si mesmo, então todos os aspectos relativos ao desenvolvimento

\footnotetext{
${ }^{1}$ Silva, M. de L. R. Personalidade e escolha profissional: subsídios de Keirsey e Bates para a
} orientação vocacional. São Paulo: EPU, 1992 (Temas básicos de educação e ensino). 
de sua personalidade passam a ser importantes para melhor compreendê-lo e auxiliá-lo no processo de sua aprendizagem.

Para Keirsey e Bates, existem quatro pares de dimensões da personalidade que atuam sempre em conjunto e estabelecem diferenciações quanto ao modo preferido de perceber e de responder às diversas situações: Extroversão/Introversão $(E / I)$, Sensação/Intuição $(S / N)$, Pensamento/Sentimento (T/F) e Julgamento/Percepção (J/P). Essas disposições apresentam-se em quatro tipos de temperamentos básicos, que podem se desdobrar em dezesseis subtipos mais específicos, conforme Kuri (2004).

\subsubsection{Definição dos objetivos educacionais}

A formulação de objetivos educacionais deve ser pautada em escolha consciente por parte do professor e fundamentada em experiências anteriores. Devem ser levados em consideração os diversos tipos de conhecimentos envolvidos e as habilidades almejadas. Todo processo de seleção final e a ordenação dos resultados de aprendizagem pretendidos devem ser fundamentados em princípios de uma teoria da aprendizagem e de acordo com a filosofia da educação que o professor ou instituição aceitam (Bloom et al., 1972).

Os objetivos de aprendizagem são declarações que descrevem aquilo que é esperado que o aprendiz alcance como resultado da instrução. As declarações estão focadas sobre o aprendiz e o tipo de comportamento que ele deve demonstrar (Mager, 1984). As Diretrizes Curriculares Nacionais para cursos de graduação em engenharia apresentadas pelo MEC (2002) também podem ser usadas como parâmetro para o projeto de cursos de graduação em Engenharia de Transportes (Silva Junior e Rodrigues da Silva, 2011b).

Em vigor desde 2002, as Diretrizes Curriculares Nacionais dos Cursos de Engenharia têm como objetivo nortear o projeto dos cursos em relação à definição dos currículos. Segundo as diretrizes, os currículos devem ser considerados muito além das atividades tradicionais realizadas em sala de aula. Deve ser formalizada uma série de atividades que possam favorecer a formação profissional dos alunos, tais como: realização de atividades de iniciação científica e tecnológica, participação em programas de extensão universitária e eventos científicos, realização de visitas técnicas, incentivos para atividades culturais, políticas e sociais. Os objetivos dessas atividades seriam ampliar os horizontes profissionais e proporcionar uma formação sociocultural mais abrangente. 
Segundo o parecer dos relatores do Conselho Nacional de Educação - Ministério da Educação, Serpa de Oliveira et al. (2001), sobre as Diretrizes Curriculares Nacionais dos Cursos de Engenharia, as tendências já naquela época direcionavam os cursos de graduação para as seguintes características:

- Estruturas flexíveis;

- Opções de áreas de conhecimento e atuação;

- Articulação com o campo de atuação do profissional;

- Enfoque nas competências;

- Abordagem pedagógica centrada no aluno;

- Ênfase na síntese e na transdisciplinaridade;

- Preocupação com a valorização do ser humano e preservação do meio ambiente;

- Integração social e política do profissional;

- Possibilidade de articulação direta com a pós-graduação;

- Forte vinculação entre teoria e prática.

Conforme o exposto acima existe uma tendência nítida de promover novos métodos de ensino-aprendizagem e consequentemente novas formas de avaliação. São claramente expostas questões relativas à aprendizagem centrada no aluno, ênfase na síntese e na transdisciplinaridade, além de formação vinculada ao ambiente social e político, valorização do ser humano e a preservação do meio ambiente. Todas estas questões estão ligadas à necessidade de atender demandas da sociedade e a dinâmica da vida contemporânea.

Outra questão igualmente importante que pode ser extraída das diretrizes em vigor é a questão da valorização do ser humano e da preservação do meio ambiente. Para corroborar esta questão, Bazzo (1998), Auler e Bazzo (2001), Cantú (2005) e Auler (2009), baseados nos estudos de CTS - Ciência, Tecnologia e Sociedade, salientam que é preciso considerar na estrutura curricular dos cursos de engenharia não apenas o estudo exclusivo de questões técnicas, mas também aspectos mais abrangentes da prática tecnológica, tais como: questões políticas, econômicas, sociais, culturais e éticas.

Conforme o exposto pode-se entender que as diretrizes curriculares possibilitam e incentivam a estruturação de cursos de engenharia que favoreçam abordagens de ensinoaprendizagem ativas e métodos de avaliação inovadores e mais articulados com as novas propostas de ensino. 
Segundo Serpa de Oliveira et al. (2001) e Tonini e Pinto (2008) as diretrizes curriculares em sua totalidade orientam para mudanças de cunho filosófico dos cursos de engenharia, bem como enfocam o uso de processos de ensino-aprendizagem centrados no estudante, com ênfase na síntese e na transdisciplinaridade. Ferraz e Belhot (2010) afirmam que decidir e definir os objetivos de aprendizagem é estruturar o processo educacional de forma a oportunizar mudanças de pensamentos, ações e condutas. Ainda segundo estes autores, a taxonomia proposta por Bloom em 1956 e atualizada em 2001 pode ajudar no planejamento, organização e controle dos objetivos de aprendizagem. Para alcançar estas metas, os objetivos educacionais devem ser formulados de forma precisa e todo o processo deve ser orientado por um plano bem estruturado (Seno e Belhot, 2008).

Os objetivos educacionais devem ser articulados com os resultados pretendidos e refletirem o desejo de explicitar o que deve ser ensinado e aprendido. A explicitação dos objetivos educacionais pode ser realizada por meio do uso de estruturas organizadas ou taxonomias que diferenciem sistematicamente resultados de aprendizagem pretendidos, comuns a determinadas áreas ou corpo de conhecimentos. Segundo a ASCE (2008), a taxonomia que melhor se adequa a essas necessidades é aquela apresentada por Bloom em 1956 e publicada originalmente como: Taxonomy of Educational Objectives, the Classification of Educational Goals, Handbook I: Cognitive Domain. Ainda segundo a ASCE (2008) esta taxonomia continua atual e seu impacto está muito bem documentado internacionalmente.

A definição dos objetivos educacionais deveria ser a primeira etapa do processo de planejamento a ser conduzido pelo professor ou instituição de ensino. Desta forma, deveria ser a base para quaisquer outras decisões relativas ao ensino-aprendizagem. Etapas como escolha de métodos de ensino e avaliação da aprendizagem precisam ser conduzidas levando-se em consideração os objetivos educacionais especificados para o curso, para a disciplina ou conjunto de disciplinas em questão.

\subsection{Especificação dos métodos e técnicas de ensino-aprendizagem}

É forte a pressão por mudanças na formação de engenheiros. A metodologia usualmente utilizada envolve a transmissão de conteúdos teóricos em sala de aula e complementação por meio de resolução de exercícios numéricos e práticas de laboratório. Estas práticas conduzem os estudantes a adquirirem apenas as habilidades necessárias para conseguirem aprovação em provas e testes (Rodrigues da Silva, 2010). 
Escrivão Filho e Ribeiro (2009) também ressaltam que na educação em engenharia no Brasil ainda há predominância de projetos pedagógicos puramente tradicionais, que possuem pouca multi-interdisciplinaridade, pouca integração entre as disciplinas, quase não há correlação entre teoria e prática e a inserção no ambiente profissional é tardia. Segundo Silvestre et al. (2010) o grande desafio é implantar formas mais dinâmicas de construção de conhecimento e que aproximem o estudante da realidade que irá encontrar no mercado de trabalho. Neste sentido, as aulas expositivas deveriam ser transformadas e combinadas com uma metodologia de aprendizagem ativa para atender às necessidades correntes de formação na atualidade.

O processo de formação baseado num estilo de ensino-aprendizagem focado no professor, no qual o estudante passa a ser apenas um mero receptor de informações deverá ser substituído ou complementado por um procedimento também voltado para o estudante. Neste processo de formação o estudante terá um papel mais ativo na construção do seu próprio conhecimento e poderá desenvolver habilidades para atuar em um ambiente interdisciplinar e mais interativo, planejar de forma efetiva o tempo de trabalho e estudo; obter desenvoltura para trabalhar em equipe e adquirir habilidades de liderança.

As questões relativas à habilidade de comunicação e trabalho em equipe são fundamentais para o profissional que irá atuar junto aos problemas de transporte e mobilidade urbana, pois trata-se de um assunto multidisciplinar, que envolve profissionais de diversas áreas. Pode-se perceber que a formação de engenheiros e profissionais de áreas afins para atuarem junto às questões de transporte e mobilidade deve ser estudada e continuamente avaliada, pois existe uma série de tendências, principalmente com relação à mobilidade urbana, que devem ser focadas não apenas sob o ponto de vista técnico, mas também a partir de um olhar crítico, imparcial e sustentável.

Diferentes abordagens de ensino-aprendizagem têm sido avaliadas nos últimos anos por pesquisadores e comparadas ao formato de ensino puramente tradicional. A principal preocupação é encontrar formas de aproveitar melhor o tempo disponível à formação dos alunos e assim criar condições de transmitir conhecimentos, habilidades e até mesmo atitudes necessárias ao profissional de engenharia (Cardoso e Silva Lima, 2011). Sendo assim, planejar o processo de ensino-aprendizagem é fundamental para otimizar o tempo em classe e obter um melhor aproveitamento dos alunos. 


\subsubsection{Aula expositiva}

Nos primórdios da humanidade, a transmissão de conhecimento passava dos pais para os filhos, dos adultos para os mais jovens. Não existiam escolas e o processo de ensinoaprendizagem acontecia por meio de preleções e experiências dos mais velhos. O processo de aprender e fazer eram concomitantes e não havia um processo formal de ensino. As primeiras escolas surgiram apenas na Idade Média, mais precisamente na Europa, e eram destinadas principalmente aos membros da nobreza e em seguida aos membros da burguesia que já começava seu processo de ascensão. A partir deste contexto, os conteúdos e métodos de ensino passaram a ser tratados de forma desvinculada do cotidiano e eram, de forma geral, abstratos (Harper et al., 1987).

No Brasil, o modelo jesuítico, presente desde a época da colonização pelos portugueses seguia o manual Ratio Studiorum, que é datado de 1599 e tem três procedimentos básicos: preleção do conteúdo pelo professor, levantamento de dúvidas por parte dos alunos e aplicação de exercícios para fixação dos conteúdos. É responsabilidade do aluno a memorização para as avaliações (Anastasiou, 1998).

$\mathrm{Na}$ metodologia tradicional de ensino-aprendizagem, a inteligência está associada à memorização. Desta forma, o trabalho docente deve envolver a explanação de conteúdos e a manutenção da atenção do aluno. A exposição ou preleção pelo professor é o centro do processo, acompanhado de anotações e memorização. Sendo assim, a estratégia neste caso é a aula expositiva tradicional (Anastasiou, 1998).

Com o aparecimento de métodos considerados mais modernos de ensino, a aula expositiva tradicional passou a ser vista como técnica ultrapassada. Além disso, os professores que continuam utilizando este tipo de aula como atividade predominante têm sido taxados de conservadores e contrários a inovações em sua prática. Mas a aula expositiva tradicional pode ser transformada em uma atividade dinâmica, participativa e estimuladora para a construção do conhecimento.

Para conduzir esta transformação o professor precisa estimular a participação, questionar, diagnosticar e conhecer a realidade dos alunos. A exposição oral passa a ser apenas uma parte do processo de ensino-aprendizagem e não a principal parte, pois a aula serve para auxiliar na exposição de um conteúdo, mas esta exposição não pode ser fechada, mecanizada ou uma verdade inquestionável. Do contrário a aula será puramente tradicional ou magistral. 
O professor pode transformar a aula puramente expositiva quando estimula o pensamento crítico e a construção do conhecimento pelo aluno. Neste tipo de aula, o professor utiliza o dialogo para criar uma relação de troca de conhecimentos e experiências com o aluno e este diálogo deve conduzir aos objetivos educacionais pretendidos. Bergamo (2010) também ressalta que a aula expositiva tradicional pode ser redescoberta e reelaborada, desde que o professor esteja disposto a dinamizar suas atividades em classe. Lopes (1991) explica que a aula expositiva que utiliza o diálogo responsável para estabelecer uma troca de conhecimentos e experiências entre professor e aluno, estimula a participação e desenvolve a "curiosidade científica", o pensamento crítico, criativo e reflexivo.

Neste contexto, as aulas tradicionais têm sofrido profundas transformações e estão tornando-se mais dinâmicas e motivadoras. Vários enfoques ou técnicas têm sido utilizados e a participação crítica, reflexiva e criativa dos alunos vem sendo cada vez mais estimulada pelos professores. Desta forma, o aluno passa a ter uma visão mais abrangente e diversificada do mundo ao seu redor. Este processo pode favorecer o ensino de engenharia, pois a relação entre conhecimento, tecnologia e sociedade também está muito mais dinâmica e a formação dos futuros engenheiros também precisa acompanhar esta tendência.

\subsubsection{Aprendizagem ativa}

Mudanças significativas na sociedade trouxeram novos rumos para a engenharia. A engenharia, de um modo geral, é definida como uma área de natureza cooperativa, feita por equipes de trabalho interdisciplinares, que requer habilidades e responsabilidades (Zhou et al., 2012 e Ferreira et al., 2013). A aprendizagem ativa pode ser considerada um conjunto de ações planejadas para auxiliar os alunos na construção de conhecimentos, competências e habilidades para atuarem de forma integrada num contexto profissional.

Para entender as dificuldades para implantação de métodos de aprendizagem ativa na educação superior, Bonwell e Eison (1991) argumentam que é preciso primeiro identificar e entender os obstáculos que impedem mudanças no contexto educacional, tais como:

- A poderosa influência da educação tradicional;

- A auto percepção e auto definição de papeis no ambiente educacional no ensino superior;

- O desconforto que as mudanças criam;

- Os limitados incentivos para a mudança. 
Como consequência dos obstáculos citados acima, Bonwell e Eison (1991) também citam barreiras específicas que estão associadas ao uso de métodos de aprendizagem ativa no ensino superior:

- Dificuldades de atender adequadamente aos conteúdos atribuídos para determinada disciplina em função do tempo disponível em sala de aula;

- Aumento do tempo necessário para preparação das atividades de ensinoaprendizagem;

- Dificuldade de desenvolver atividades de aprendizagem ativa em turma com muitos alunos;

- A falta de materiais, equipamentos ou recursos necessários para desenvolver atividades num formato de aprendizagem ativa.

Sendo assim, podem ser citados como fatores que desencorajam o uso da aprendizagem: o receio de que os estudantes não participem das atividades de forma efetiva; não usem raciocínio de ordem superior; não "aprendam" o conteúdo de forma satisfatória; o sentimento da perda do controle das atividades por parte dos professores; deficiências na aquisição das habilidades pretendidas ou críticas ao uso de um método de ensino-aprendizagem não tradicional. Porém, estes fatores muitas vezes são apontados como riscos inerentes ao uso da aprendizagem ativa. Mas também cada uma dessas dificuldades pode ser superada por meio de um cauteloso e eficiente planejamento (Bonwell e Eison, 1991).

O termo aprendizagem ativa algumas vezes é usado de forma muito abrangente e alguns educadores consideram que toda aprendizagem é inerentemente ativa. Desta forma, consideram que estudantes, ao ouvirem uma apresentação formal em sala de aula, também podem está participando de uma atividade de aprendizagem ativa. Porém, os estudantes devem fazer mais do que ouvirem. Devem ler, escrever, debater ou resolver problemas (Bonwell e Eison, 1991).

Mesmo diante dessas dificuldades e obstáculos, muitas instituições no Brasil e em outros países têm utilizado e aprimorado o uso de atividades de aprendizagem ativa. Algumas dessas atividades orientam um curso e o corpo docente inteiro na forma de um currículo integrado. Outras atividades são conduzidas de forma mais isolada por apenas alguns professores nas disciplinas sob sua responsabilidade.

Um dos métodos de aprendizagem mais conhecidos e estudado é o PBL - Problem Based Learning. Nesta abordagem, os problemas estruturados são retirados de contextos reais e complexos, as atividades geralmente são feitas em equipes de trabalho e o professor 
cumpre o papel de facilitador. Uma das grandes dificuldades para a implementação de atividades de aprendizagem ativa é a questão do tempo necessário para desenvolver as tarefas. Quinn e Albano (2008), ao relatarem as conclusões sobre o uso de $P B L$, ressaltam que as atividades exigiram maior investimento de tempo em relação às atividades consideradas tradicionais.

Diversos estudos apontam para uma série de vantagens a respeito do uso de métodos de aprendizagem ativa e PBL. Entre estas vantagens, podem ser citadas: aumento significativo do conhecimento formal e tecnológico; mudança positiva na atitude em relação à tecnologia e aos estudos sobre aplicações tecnológicas; melhor assimilação dos temas tratados; melhor compreensão conceitual sobre temas relativamente complexos (Mioduser e Betzer 2007; Minner et al., 2010; e Fini e Mellat-Parast, 2012).

Outra forma de aprendizagem ativa é a Metodologia da Problematização ou Aprendizagem Baseada na Resolução de Problemas (ABRP), ou simplesmente Resolução de Problemas. Nesta abordagem, o professor não apresenta aos alunos um problema estruturado e fechado, mas dá aos alunos um contexto problemático e a partir deste contexto eles avaliam o que é interessante e motivador para ser estudado. Vale ressaltar que este processo é conduzido pelo professor tendo em vista a área de conhecimento e os conteúdos necessários para a resolução de problemas, bem como os resultados de aprendizagem que foram estipulados inicialmente.

A diferença em termos operacionais entre o $P B L$ e a metodologia da problematização está no fato de que nesta metodologia o problema não é formulado e apresentado de forma estruturada ou fechada para ser resolvido pelos alunos (Berbel, 1998). Os alunos percebem ou visualizam um problema a partir de um contexto problemático. Segundo Loureiro (2008), estes contextos problemáticos podem ser apresentados aos alunos de diversas formas, tais como: uma entrevista ou reportagem da mídia em geral; um estudo de caso; um fato real vivido pelos alunos ou pela comunidade; etc. Leite e Esteves (2006) ressaltam que, neste tipo de abordagem, o foco passa a ser a aprendizagem e não o ensino.

Uma das principais características do método da resolução de problemas é a mudança do foco do ensino para o processo de ensino-aprendizagem. Isso exige do aluno responsabilidade pela sua formação, uma vez que nesta abordagem o aluno necessita ter uma postura ativa, ou seja, realizar uma série de tarefas para alcançar soluções para o problema a ser resolvido. As atividades podem ser conduzidas em grupo e possibilitam a 
simulação de ambientes ou contextos problemáticos do cotidiano ou do futuro ambiente profissional.

Para Boud e Feletti (1997) a principal vantagem da ABRP está no fato de que os métodos de ensino tradicionais enfatizam a memorização de conhecimentos que são considerados atuais naquele momento e não estimulam o aprendizado constante. Isto pode resultar na desatualização dos egressos muito rapidamente, pois os avanços tecnológicos em praticamente todas as áreas têm se processado de forma mais rápida e contínua.

A diferença básica entre a ABRP e o $P B L$ está no fato de que a primeira metodologia pode ser utilizada no processo de ensino-aprendizagem de determinados temas dentro de uma disciplina, como opção do professor, requer poucas alterações em termos de recursos materiais e espaços físicos, demanda apenas mudanças na programação da disciplina e na postura do professor e dos alunos para uma reflexão crítica dos temas. Por outro lado, nem sempre é apropriada para todos os conteúdos. Já a segunda metodologia pode direcionar toda uma organização curricular de forma integrada e é uma opção de todo um corpo docente, administrativo e acadêmico, podendo implicar até em alterações de recursos materiais, espaço físico e horário das atividades (Berbel, 1998).

O processo de organização das atividades na metodologia ABRP pode ser estruturado em quatro etapas, segundo Leite e Afonso (2001):

- 1a Etapa: Consiste na seleção de um contexto problemático, de onde possam ser extraídos problemas a serem tratados com os conhecimentos relativos à disciplina ou curso em questão, que geralmente é realizada exclusivamente pelo professor. $O$ professor deve buscar contextos que se adequem ao nível dos alunos, que possam motivá-los a buscar soluções e que conduzam para os resultados de aprendizagem pretendidos;

- 2a Etapa: É feita a formulação de problemas e acontece com base nas ações dos alunos em relação ao contexto problemático previamente selecionado pelo professor. Neste caso o professor deve desenvolver apenas um papel de orientação do processo. De acordo com a formulação feita pelos alunos, são realizadas análises conjuntas entre professor e alunos para avaliar se os problemas apresentados são viáveis do ponto de vista técnico-científico e podem conduzir aos resultados de aprendizagem pretendidos;

- 3a Etapa: Trata-se da resolução do problema propriamente dita. Nesta etapa o professor desempenha o papel de orientação em relação ao trabalho a ser efetuado, cabendo aos alunos conduzir a resolução do problema. 
- 4a Etapa: Nesta etapa ocorre uma avaliação geral do processo. São verificados se os problemas foram resolvidos ou não possuem solução plausível para aquela situação. Isto é feito tendo como base em uma síntese final dos conhecimentos alcançados ou desenvolvidos, em termos conceituais, procedimentais e atitudinais, bem como uma avaliação geral de todo o processo em termos de eficácia da aprendizagem, em termos de desenvolvimento pessoal, social e ético.

Ainda com relação às etapas da ABRP, Berbel (1998) apresenta uma quinta etapa. Esta etapa consistiria na aplicação das soluções à realidade ou contexto problemático. Segundo a autora, o objetivo é levar os alunos a exercitarem a relação prática-teoria-prática, sendo o ponto de início e fim o processo de ensino-aprendizagem e a realidade social do aluno.

Vale ressaltar que a metodologia da problematização pode ser utilizada em conjunto com aulas expositivas e outros recursos para torná-las mais dinâmicas e motivadoras. Segundo Lambros (2004), os métodos de ensino tradicionais não devem ser abandonados para a implementação de metodologias ativas de ensino-aprendizagem. Ao invés disso, segundo este autor, o uso dessas metodologias deveria melhorar a efetividade das técnicas tradicionais de ensino.

Desta forma, a busca de mecanismos ou métodos para aperfeiçoar o processo de ensinoaprendizagem pode passar pelo uso de métodos mistos. Estes métodos podem compreender a fusão de diversas técnicas com aulas tradicionais. Francis e Shannon (2013) realizaram um estudo de caso sobre a introdução de métodos mistos em disciplinas de projeto e arquitetura para engenharia. As técnicas mistas compreenderam atividades online e aulas presenciais. Segundo as autoras, os alunos que não se envolveram no estudo de caso ficaram em desvantagem acadêmica. Nesta pesquisa houve alinhamento em relação ao método misto de ensino e os resultados de avaliação. Também foram usados métodos de pesquisa qualitativa para estabelecer quais barreiras poderiam impedir a adoção de métodos de ensino-aprendizagem considerados mistos.

Em uma pesquisa realizada no final das atividades de uma disciplina que foi baseada em e-learning, aprendizagem colaborativa, aprendizagem baseada em problemas ( $P B L)$ e em aprendizagem independente (Hoic-Bozic et al., 2009), relatam que os alunos estavam satisfeitos com a abordagem pedagógica. Além disso, o desempenho acadêmico foi melhor do que o esperado. Outra questão apresentada por estes autores e particularmente importante é que a taxa de evasão na disciplina diminuiu sensivelmente, o que poderia estar 
relacionado com a satisfação dos alunos, com o apoio recebido do instrutor e com o método misto empregado.

Os procedimentos de ensino-aprendizagem devem ser escolhidos e utilizados com muito critério durante a formação de engenheiros. Na atualidade, o uso de aulas expositivas isoladas não pode garantir mais a aquisição de competências e habilidades necessárias aos futuros engenheiros para atender às demandas da sociedade, principalmente na área de Engenharia de Transportes. Por outro lado, o uso do método PBL de aprendizagem ativa pode ser muito trabalhoso e oneroso. Uma técnica alternativa mais simples e promissora que pode ser utilizada em conjunto com aulas expositivas é a Metodologia da Problematização. Justifica-se o emprego desta metodologia por diversos motivos, tais como:

- A metodologia da problematização pode ser empregada em disciplinas isoladas sem a necessidade de integração com outras disciplinas;

- Em cursos de graduação que possuem extensos conteúdos de natureza técnica e envolvem aplicações físicas e matemáticas, as aulas expositivas são um método de ensino viável, eficaz e que não podem ser suprimidos das atividades de ensinoaprendizagem;

- Em alguns contextos existe a necessidade de motivar os alunos a participarem das atividades de ensino-aprendizagem de uma forma mais socialmente comprometida. Neste caso, pode-se incluir a Engenharia de Transportes e seus temas.

Ao participar de uma atividade no formato de aprendizagem ativa, os alunos podem atuar de forma mais crítica, reflexiva e criativamente. Caso esta abordagem também seja desenvolvida em equipes ou grupos de trabalho, o processo pode envolver situações de compartilhamento de ideias ou colaboração entre os pares. Isto pode atender questões relativas não apenas ao domínio conceitual ou domínio de relação conceitual, mas também procedimentos cognitivos relacionais e atitudinais.

\subsection{Avaliação do ensino-aprendizagem - Avaliação do produto}

O processo de avaliação da aprendizagem no ambiente educacional foi, de um modo geral, transformado no simples ato de verificação da aprendizagem, segundo Luckesi (2011) e ABET (2012). Na verificação da aprendizagem, os resultados são simplesmente transformados em registros escolares. Estes registros, segundo Corrêa (2009), são aplicados apenas sob uma perspectiva classificatória, ao invés de uma perspectiva formativa. Na perspectiva formativa os mecanismos de avaliação atuam como subsidio e orientam possíveis intervenções para sanar 
equívocos de aprendizagem. Uma ferramenta que atua na direção de uma avaliação da aprendizagem formativa são os mapas conceituais. Segundo vários estudos, estes mapas podem auxiliar na identificação de dificuldades e na reconstrução do processo de ensinoaprendizagem que deve envolver o professor e o aluno.

A seguir são apresentadas questões relativas à Aprendizagem Significativa desenvolvida por David Ausubel, Mapas Conceituais conforme Joseph D. Novak e a utilização dos Mapas Conceituais como ferramenta para atestar Aprendizagem Significativa.

\subsubsection{Aprendizagem significativa}

David Ausubel publicou, em 1963, o modelo da Aprendizagem Significativa. Este modelo sofreu forte influência dos trabalhos de Piaget (Ausubel et al., 1980; Moreira e Masini, 1982; Palmero, 2004) e pode ser considerada uma teoria psicológica da aprendizagem em sala de aula. Ausubel construiu um arcabouço teórico que tem por finalidade explicar os mecanismos envolvidos na aquisição e retenção dos grandes corpos de conhecimento que são manuseados na escola. A ênfase está sobre o que ocorre em aula quando os estudantes aprendem, na natureza desta aprendizagem, nas condições necessárias para que esta se produza, em seus resultados e, consequentemente, na sua avaliação (Palmero, 2004).

A aprendizagem significativa tem como base principal o conceito de subsunçor. Um subsunçor é uma estrutura cognitiva prévia na qual outros conceitos ou conhecimentos podem ser ancorados para alterar ou gerar novos conhecimentos. Desta forma, o modelo da Aprendizagem Significativa considera que os indivíduos aprendem significativamente com base nos conhecimentos que já possuem, ou seja, seus subsunçores ou conhecimentos prévios.

Sobre a questão da eficácia e retenção dos conhecimentos apresentados a um grupo de alunos, Moreira e Masini (1982), ao se referirem à teoria da Aprendizagem Significativa de David Ausubel, salientam que a ideia central desta teoria é a de que o fator isolado mais importante que pode influenciar a aprendizagem é aquilo que o estudante já sabe sobre um determinado tema. Sendo assim, para que a aprendizagem ocorra de forma significativa, o novo conteúdo apresentado deve estar relacionado a conhecimentos prévios que façam parte da estrutura cognitiva do aluno.

Desta forma, os conteúdos prévios ou organizadores prévios são materiais para introdução de um determinado assunto ou conhecimento. Devem ser apresentados de forma geral, com 
o máximo de abrangência em relação ao conteúdo que será tratado especificamente e servem como ligação entre aquilo que o aluno já sabe e o que ele deverá saber para poder entender de forma significativa o novo conteúdo. O objetivo principal dos organizadores prévios é facilitar a aprendizagem significativa, caso o aluno não possua na sua estrutura cognitiva os conceitos relevantes para a aprendizagem de um determinado assunto. Se estes organizadores não forem usados, a aprendizagem poderá ocorrer de forma mecânica.

Conforme ressalta Pelizzari et al. (2002) a teoria da Aprendizagem Significativa de David Ausubel propõe que os conhecimentos prévios dos alunos sejam identificados e valorizados. Ainda segundo estes autores, os mapas conceituais podem ser usados para construir estruturas mentais. Isto pode permitir a descoberta e a redescoberta de outros conhecimentos.

O contrário da aprendizagem significativa seria a aprendizagem mecânica, que ocorre de forma arbitrária e tem como base a memorização de conteúdos. Durante o processo de aprendizagem é impossível excluir totalmente a aprendizagem mecânica e gerar somente aprendizagem significativa. A apresentação de novos conhecimentos muitas vezes exige que o aluno realize aprendizagem mecânica e este conhecimento adquirido mecanicamente pode tornar-se um subsunçor para posteriormente criar aprendizagem significativa (Moreira e Masini, 1982).

Desta forma, para que o processo de aprendizagem seja significativo, é necessário determinar o que o aluno já sabe para, então, avançar com novos conceitos em conformidade com os conhecimentos prévios. O resultado deste processo pode ser verificado quando, de forma consciente e explicitamente, o aluno estabelece ligações deste novo conhecimento com os conceitos prévios e relevantes que já possuía (Souza, 2005).

Segundo Souza e Boruchovitch (2010a) quando uma aprendizagem é significativa, podem ocorrer alterações na estrutura cognitiva do aprendiz, mudando os conceitos preexistentes e formando novas ligações entre os conceitos. As autoras ressaltam que a aprendizagem significativa é permanente e poderosa, enquanto a aprendizagem desvinculada de um contexto de significado é facilmente esquecida e não é facilmente aplicada em novas situações de aprendizagem ou solução de problemas.

Desta forma, podem ser enunciados três fatores, que segundo Ausubel et al. (1980) são necessários para que ocorra aprendizagem significativa: ) Para aprender significativamente é necessário que o aluno esteja predisposto a ligar as novas informações aos conceitos e 
proposições pré-existentes na sua estrutura cognitiva; ii) Os novos conhecimentos devem ser apresentados de forma clara e em um nível compatível com a estrutura cognitiva do aluno; e iii) Os conhecimentos prévios ou ideias âncoras necessários para o entendimento do novo conhecimento a ser apresentado devem ser dominados pelo aluno.

\subsubsection{Diferenciação progressiva e reconciliação integrativa}

A teoria da Aprendizagem Significativa possui dois princípios muito importantes: diferenciação progressiva e reconciliação integrativa. Estes dois princípios são a base para a programação de conteúdos e para a construção de Mapas Conceituais. A diferenciação progressiva é a modificação conceitual de um subsunçor, pois um novo conhecimento foi adquirido e acoplado à estrutura cognitiva do aluno. Este novo subsunçor é mais específico e diferenciado do que o subsunçor que foi modificado. Já a reconciliação integrativa ocorre quando é possível estabelecer relações entre subsunçores que antes não estavam claras ou visíveis para o aluno.

A diferenciação progressiva está ligada à hierarquização dos conceitos e ocorre de forma que haja disposição desde os mais abrangentes até os mais específicos. Isto envolve o fato de que é mais fácil aprender a partir de conceitos mais abrangentes ou inclusivos, até chegar aos conceitos mais específicos e menos inclusivos. Além disso, o processo de aprendizagem implica em organização hierárquica do conhecimento na estrutura cognitiva do aprendiz.

Disto decorre o fato de que o ensino numa disciplina deveria iniciar a partir de conceitos gerais para chegar aos conhecimentos específicos e particulares, conforme ressalta Faria (1989), citado em Souza e Boruchovitch (2010a). Um tópico servirá de ideia ou ideias de esteio para os subtópicos em que se subdivide; ou ainda, na sequência dos tópicos, se ordenados com o princípio da diferenciação progressiva, aqueles que vierem antes fornecerão base de assimilação ou esteio para os que vierem depois.

A reconciliação integrativa pode ser entendida como a reorganização ou modificação de conceitos que adquiriram novos significados. Desta forma, por meio deste princípio pode ocorrer uma espécie de recombinação dos elementos existentes na estrutura cognitiva do aprendiz. Além disso, para que isto ocorra o material instrucional deve explorar relações entre ideias, buscar similaridades e diferenças e por fim, reconciliar discrepâncias reais ou aparentes (Moreira e Masini, 1982). 
De um modo geral a teoria da aprendizagem significativa, segundo Palmero (2004), pode ser entendida como um processo que ocorre na mente humana quando esta é submetida a novos conhecimentos. Estes conhecimentos devem ser não arbitrários e de caráter relevante. Além disso, requer predisposição para aprender; deve existir relevância lógica do conhecimento apresentado e presença de conhecimentos prévios ou ideias âncoras na estrutura cognitiva do aprendiz. Ainda segundo este autor, a aprendizagem significativa tem suas bases em diferentes teorias psicológicas e pedagógicas. Pode ser considerada mais integradora e promissora à aplicação em um contexto de sala de aula, pois oferece meios tangíveis de adequar o processo de ensino-aprendizagem.

Com base no exposto no parágrafo anterior fica clara a necessidade de mapear a estrutura conceitual cognitiva do aluno. Ao utilizar uma ferramenta que possa cumprir esta tarefa, o professor terá condições de melhor planejar suas atividades de ensino-aprendizagem, em relação a um novo conteúdo ou conhecimento a ser apresentado. No próximo item serão apresentados alguns conceitos e pesquisas que envolvem o uso de Mapas Conceituais. Esta ferramenta tem se mostrado promissora em diversas situações em relação à aprendizagem significativa, tais como: organização da estrutura curricular ou da estrutura de uma disciplina; identificação de organizadores prévios; método de ensino-aprendizagem; mapeamento da evolução da aprendizagem do aluno (instrumento de avaliação), etc.

\subsubsection{Mapa conceitual}

O mapa conceitual é uma ferramenta pedagógica proposta por John Novak na década de 1970. Pode ser usado para representar graficamente conceitos e suas relações. A teoria da Aprendizagem Significativa é a base para a construção de mapas conceituais. Esta teoria possui dois princípios muito importantes: diferenciação progressiva e reconciliação integrativa. Estes dois princípios norteiam a programação de conteúdos e a construção de Mapas Conceituais.

Os mapas conceituais podem servir como uma estratégia de ensino-aprendizagem ou uma ferramenta avaliativa - dentre outras diversas e multifacetadas possibilidades. Vale ressaltar que nada se dá desvinculado de um modelo de educação com características bem demarcadas, de forma que usar o mapa conceitual é assumir o compromisso de efetivar um ensino centrado no aluno e não no professor. Busca-se também o desenvolvimento 
simultâneo das dimensões pessoais e não apenas as intelectuais (Moreira e Masini, 2001²; Ontoria et al., 2005³; Moreira, 2006 ${ }^{4}$ ), citados em (Souza e Boruchovitch, 2010a).

Como ferramenta para avaliação do processo de ensino-aprendizagem, Novak (2003) ressalta que o mapa conceitual construído pelo aluno permite identificar suas ideias válidas e seus equívocos sobre determinado conhecimento, favorecendo o acompanhamento dinâmico da avaliação. Com base nisto é possível estabelecer de fato um processo de avaliação da aprendizagem, ao invés de apenas realizar a verificação da aprendizagem, conforme ressalta Luckesi (2011).

Um exemplo de mapa conceitual é apresentado na Figura 2.3. Para a construção deste mapa foram fornecidos 10 conceitos-chaves e a partir destes foram acrescentados outros conceitos e frases de ligação. Neste exemplo podem ser observados os princípios da diferenciação progressiva e reconciliação integrativa. A diferenciação progressiva pode ser observada pela apresentação de exemplos específicos à medida que o mapa se desenvolve verticalmente. Bem como, os conceitos mais inclusivos ou abrangentes estão posicionados acima de conceitos menos inclusivos ou mais específicos. Já a reconciliação integrativa pode ser observada nas relações que acontecem no sentido inverso, ou seja, de baixo para cima. Neste exemplo específico, em duas situações.

O Mapa conceitual da Figura 2.3 foi construído usando o software CmapTools versão 5.05.01. Este software possui uma série de recursos e permite a elaboração de mapas de forma dinâmica, interativa e compartilhada. Pode ser obtido no site http://cmap.ihmc.us/ sem custos de aquisição. Existe a opção de obter o software mediante a contribuição voluntária de pelo menos dez dólares americanos ou comprar um cópia física em CD-Rom pela quantia de cinquenta dólares americanos.

O uso de uma ferramenta de avaliação dinâmica e construtiva possibilita avaliar de fato a evolução do domínio conceitual por parte dos alunos. Os mapas conceituais combinados às provas tradicionais podem contribuir para um processo mais fidedigno de avaliação, evitar

\footnotetext{
${ }^{2}$ Moreira, M. A. e E. F. S, Masini (2001). Aprendizagem significativa: A teoria de David Ausubel. São Paulo: Centauro.

${ }^{3}$ Ontoria, A.; A. Ballesteros; C. Cuevas; L. Giraldo; I. Martín; A. Molina; A. Rodríguez e U. Vélez (2005). Mapas conceituais: uma técnica para aprender. São Paulo: Loyola, 238 p.

${ }^{4}$ Moreira, M. A. (2006). A teoria da aprendizagem significativa e sua implementação em sala de aula. Brasília: Editora Universidade de Brasília.
} 
possíveis equívocos e garantir um processo de avaliação de fato, conforme ressalta Luckesi (2011).

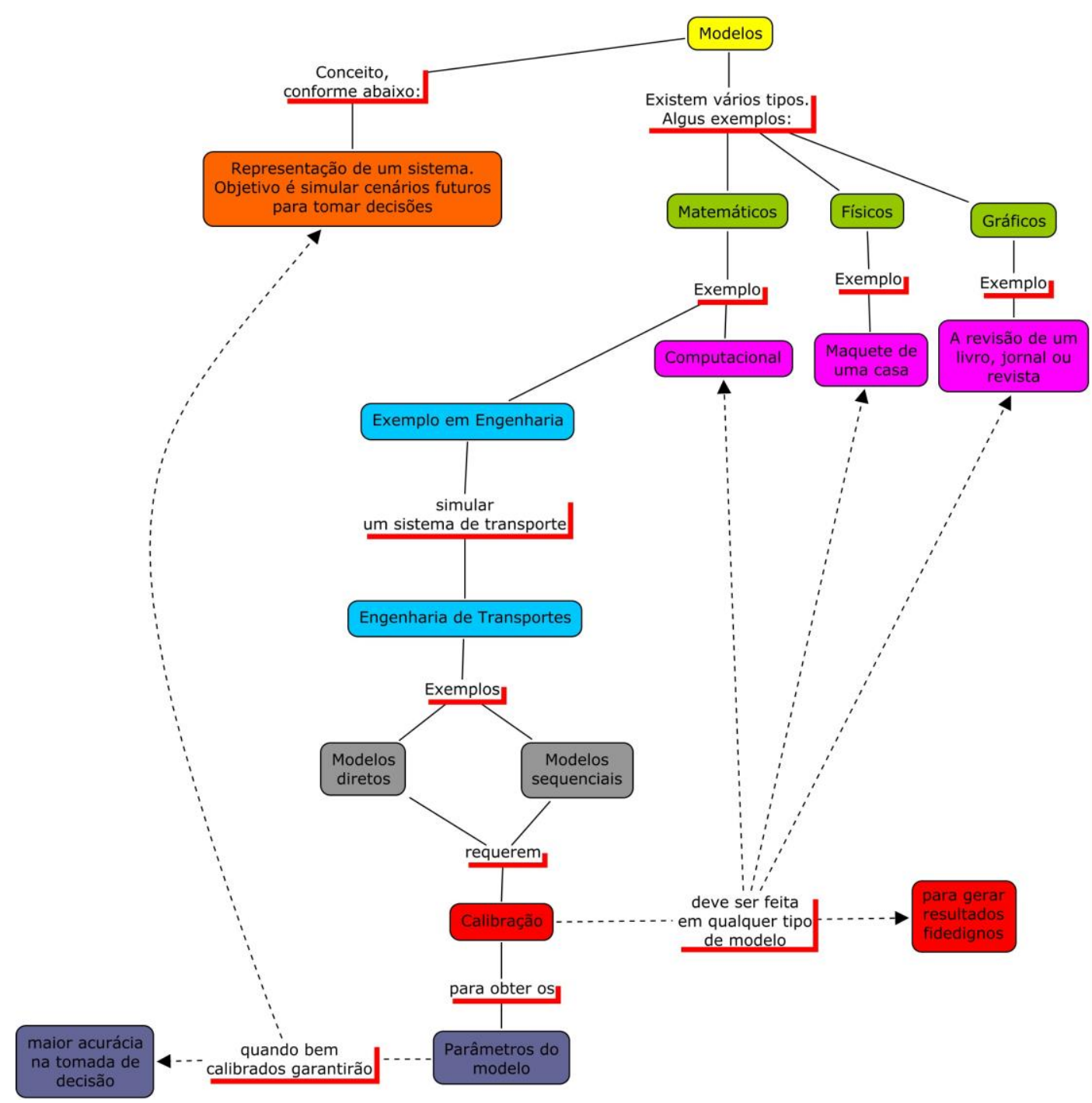

Figura 2.3: Exemplo de mapa conceitual.

Desta forma, os mapas conceituais dos alunos podem ser usados a serviço da avaliação formativa, como meio para se alcançar um fim: assegurar que o aluno aprenda e se desenvolva. Serve também para procurar atender o desenvolvimento de destrezas cognitivas variadas e não se conformar apenas com a repetição mecânica da informação por parte do estudante.

Cantú (2005) utilizou a definição de Darmofal et al. (2002) sobre Conceitos Abstratos e Conceitos Concretos para justificar o emprego da Teoria da Aprendizagem Significativa e dos Mapas Conceituais no ensino de Redes de Computadores. Segundo Cantú (2005) o ensino desta disciplina requer níveis de abstrações elevados e por isso requer cuidados adicionais na preparação do processo de ensino-aprendizagem. Esta preparação cuidadosa 
pode ser feita usando os Mapas Conceituais como organizadores do programa da disciplina e dos conceitos que serão desenvolvidos em sala de aula. Desta forma, procura-se tornar clara a importância prática e as generalizações do que vai ser aprendido.

Com relação à questão da avaliação dinâmica, ideias válidas e equívocos em mapas conceituais, Cantú (2005) ressalta que não existe um mapa conceitual definitivo ou até mesmo "o mapa conceitual" que possa representar de forma única um problema, uma situação ou um conjunto de conhecimento. Os mapas construídos a respeito de um assunto, por diferentes alunos, professores ou especialista geralmente terão organização hierárquica e relações conceituais diferentes.

Com relação à construção de mapas conceituais, Novak (2003) estabelece de forma bem sucinta os passos que podem ser seguidos, como segue:

- Definição de uma atividade (assunto, área de conhecimento ou problema) a ser resolvida ou apresentada por meio de um mapa conceitual;

- Sugerir uma lista de 10,15 a 20 conceitos que podem caracterizar a atividade;

- Ordenar os conceitos sugeridos dos mais gerais aos mais específicos;

- Iniciar o mapa com 1 a 4 conceitos mais gerais;

- Estabelecer ligações entre os conceitos, formando proposições;

- Incluir novos conceitos e seguir a construção hierárquica;

- Buscar ligações cruzadas, que possam estabelecer ligações entre partes distintas e aparentemente não relacionadas no mapa;

- Reestruturar o mapa de modo a estabelecer a melhor disposição dos conceitos e as ligações cruzadas.

O processo de construção de mapas conceituais pode ser manual ou computadorizado. Atualmente, com a disponibilidade cada vez mais frequente de computadores e software livre no ambiente educacional, a construção de mapas de forma manual é pouco praticada e usual. Existem algumas ferramentas computacionais desenvolvidas especificamente para a construção de mapas. Na Tabela 2.1 são apresentadas algumas informações sobre dois software que podem ser utilizados para a construção e manipulação de mapas conceituais.

Diversos autores, como Struchiner et al. (1999), Souza (2004), Cantú (2005), Mendonça e Carvalho (2007), Stange Lopes (2007), Tavares e Luna (2007), Machado e Nardi (2008) Corrêa (2009), Souza e Boruchovitch (2010a), Souza e Boruchovitch (2010b), Souza e Boruchovitch (2010c), Antunes (2011), Toigo et al. (2011), Krummenauer (2012) e Silva (2012) pesquisaram e 
descreveram o uso de mapas conceituais. Trataram de diversos aspectos, tais como: proposta curricular; ferramenta de ensino-aprendizagem em sala de aula; avaliação do processo de ensino-aprendizagem; suporte à navegação na web e como ferramenta de apoio computacional. Todos os conceitos aqui discutidos constituíram a base para a metodologia aplicada neste estudo.

Tabela 2.1 - Software livre para construção e manipulação de mapas conceituais

Software

Características

Endereço Eletrônico

\begin{tabular}{ll}
\hline & Permite construção e manipulação de mapas \\
& conceituais; \\
Possui módulo de aprendizagem colaborativa; & \\
Desenvolvido na Universidade de Pittsburgh - USA; $\quad$ http://belvedere.sourceforge.net \\
Distribuído atualmente pelo Laboratório de \\
Tecnologias Interativas de Aprendizagem da \\
Universidade do Hawaii - USA. \\
\\
Possibilita a construção, manipulação e publicação \\
na Web de mapas conceituais; \\
Desenvolvido pelo Instituto para a Cognição \\
Humana e Artificial da Universidade do Oeste da \\
Florida - USA.
\end{tabular}

\subsection{Conclusões do capítulo}

As mudanças ocorridas nas últimas décadas têm trazido uma série de desafios à humanidade. Esses desafios envolvem a resolução de problemas nas mais variadas áreas do conhecimento. Abrangem questões relativas a assuntos econômicos, sociais, ambientais, tecnológicos, etc. Também podem ser mais ou menos impactantes, em função de questões regionais e geográficas. Uma coisa, porém, pode ser considerada certa: é preciso estar preparado para enfrentar e equacionar estes problemas.

Uma grande parcela destes problemas é relativa a questões de infraestrutura e operação de sistemas e serviços urbanos. No caso do Brasil, há uma tendência de que uma quantidade cada vez maior de pessoas estabeleça suas moradias e desenvolva suas atividades profissionais em grandes áreas urbanas. Para atender a estas populações com serviços públicos de qualidade, é preciso planejar, construir e operar uma série de sistemas, tais como: distribuição de água, coleta de esgoto e lixo; energia elétrica; telefonia e internet; transportes; etc. 
Desta forma, o profissional de engenharia, de um modo geral, passa a ter um papel relevante e cada vez mais estratégico neste cenário. É preciso, além de formar mais engenheiros, formar e preparar engenheiros capazes de entenderem as reais demandas deste mundo contemporâneo e cada vez mais urbano. Sendo assim, é necessário desenvolver, testar e aplicar métodos que possam aproximar os futuros engenheiros dos desafios que eles irão enfrentar no cotidiano de suas atividades profissionais.

Mudanças no processo de formação de engenheiros têm ocorrido em diversas partes do mundo. Existe uma série de propostas e estudos que apontam quais as melhores ou mais coerentes formas de ensino-aprendizagem em diversas áreas do conhecimento. Porém, para que novos métodos educacionais possam ser uma realidade num futuro próximo, é preciso principalmente que professores e alunos aceitem que é preciso adotar formas mais apropriadas de ensino-aprendizagem em cursos de graduação de engenharia.

É necessário que tanto professores quanto alunos entendam como importantes os métodos de planejamento, desenvolvimento e avaliação do ensino-aprendizagem. As teorias de estilos de aprendizagem, perfis de personalidade, taxonomias de objetivos educacionais, os recursos de ensino em sala de aula ou laboratórios, métodos de aprendizagem ativa (combinados ou não com métodos tradicionais), métodos inovadores de avaliação do ensino-aprendizagem (mapas conceituais, por exemplo), só poderão de fato contribuir à formação de engenheiros, se alunos e professores os reconhecerem como importantes e não apenas como etapas a serem cumpridas como exigências legais ou institucionais.

Por mais que os métodos considerados inovadores não sejam aceitos como eficazes ou aplicados na prática. Ainda assim, os métodos tradicionais precisam ser melhorados ou até mesmo transformados em formas mais dinâmicas de ensino-aprendizagem. Desta forma, a ação e o reconhecimento de alunos e professores, em relação a todo o processo de ensinoaprendizagem, são fundamentais para gerar boas soluções ou propostas para aqueles desafios já mencionados e que já fazem parte do cotidiano. 


\section{MÉTODO}

A participação direta no ambiente de ensino-aprendizagem, necessária para esta investigação, se deu em uma disciplina obrigatória de um curso de Engenharia Civil da Escola de Engenharia de São Carlos da Universidade de São Paulo. A finalidade foi obter informações e analisar a complexidade envolvida nas diversas atividades realizadas, dentro e fora de sala de aula. Neste caso, a disciplina selecionada trata de Planejamento e Análise de Sistemas de Transportes (sexto semestre do curso) e envolveu alunos, professores, monitores e o pesquisador, que também atuou como tutor nas atividades da metodologia da problematização ou resolução de problemas. Para atingir o objetivo proposto, ou seja, introduzir, monitorar e avaliar alterações em uma abordagem pedagógica que mescla aulas expositivas e aprendizagem ativa, três etapas foram realizadas: i) planejamento do ensinoaprendizagem; ii) avaliação do processo de ensino-aprendizagem; e iii) avaliação do produto de ensino-aprendizagem.

A investigação necessária para esta pesquisa se deu em dois períodos letivos, isto é, nos anos de 2012 e 2013. Desta forma, foi possível fazer análises mais abrangentes das turmas em anos letivos diferentes. Também foi possível avaliar algumas alterações no procedimento experimental, principalmente com relação à aplicação dos mapas conceituais como ferramenta de avaliação da aprendizagem.

O primeiro período letivo correspondeu ao segundo semestre de 2012. Nesta ocasião foi feito o experimento em apenas uma turma da disciplina Planejamento e Análise de Sistemas de Transportes. Nesta turma os métodos de ensino empregados basicamente compreenderam o uso de aulas tradicionais, aprendizagem ativa na forma de metodologia da problematização ou resolução de problemas e outras técnicas para dinamizar as aulas tradicionais ou expositivas.

No segundo período letivo, que compreendeu o segundo semestre de 2013 , houve algumas diferenças em relação ao ano letivo de 2012. Em 2013, o experimento foi aplicado em duas turmas da mesma disciplina do ano anterior. Em uma das turmas (Turma 1), os métodos de ensino estiveram mais alinhados com aulas tradicionais ou expositivas. Na outra turma (Turma 2), além das aulas tradicionais ou expositivas, ocorreu a aplicação de uma atividade no formato de aprendizagem ativa, tal como no ano anterior. 
Os procedimentos conduzidos no segundo semestre de 2013 possibilitaram tecer algumas análises para as duas turmas do mesmo ano letivo e também em relação à turma do ano letivo anterior. Estes procedimentos foram possíveis em função de toda a dinâmica desenvolvida nas diversas etapas. No caso das turmas de 2012 e 2013 foi possível traçar análises em função do perfil de personalidade das turmas, desenvolvimento das atividades e resultados obtidos em termos de avaliação da aprendizagem. Já com relação às turmas do ano letivo de 2013, as análises envolveram as diferentes dinâmicas empregadas em cada turma, tais como: a escolha dos alunos em relação às Turmas 1 ou 2; estilos de aprendizagem e perfis de personalidade; aplicação da metodologia da problematização ou resolução de problemas; resultados relativos à comparação dos mapas conceituais com a média final obtida pelos alunos; etc.

Vale ressaltar que no ano letivo de 2013 os alunos tiveram a oportunidade de decidir em qual turma gostariam de realizar a disciplina. A escolha podia ser pela Turma 1, que não faria a atividade de aprendizagem ativa e teria apenas aulas tradicionais ou expositivas, ou pela Turma 2, que faria a atividade de aprendizagem ativa além das aulas tradicionais ou expositivas. Este processo de escolha da turma, por parte dos alunos, gerou algumas expectativas em relação à pesquisa, tais como: $l$ ) os alunos escolheriam a turma conforme seu perfil de personalidade?; ii) a escolha seria baseada nas preferências de aprendizagem?; ou iii) simplesmente os alunos escolheriam a sua turma com base no processo de ensino-aprendizagem que estavam habituados a frequentar nas demais disciplinas?

A Turma 1, que teria apenas atividades consideradas tradicionais, era composta de 27 alunos, um docente, um monitor e o pesquisador. Este monitor fazia parte do Programa de Aperfeiçoamento de Ensino - PAE, da Universidade de São Paulo. Este programa é direcionado aos alunos de pós-graduação (mestrado e doutorado) e tem como principal objetivo aprimorar a formação do pós-graduando para atividades didáticas de graduação. $O$ programa é composto de duas etapas: Preparação Pedagógica e Estágio Supervisionado em Docência.

A Turma 2, na qual seria desenvolvida a atividade de aprendizagem ativa em conjunto com aulas tradicionais ou expositivas, era composta por 25 alunos, um docente, um monitor (PAE/USP) e o pesquisador. Na Tabela 3.1 estão apresentadas as etapas desenvolvidas para cada uma das turmas no ano de letivo de 2013. Com relação ao ano de letivo de 2012, as etapas de preparação corresponderam aquelas que foram feitas para a Turma 2 do ano letivo de 2013. 
Tabela 3.1 - Etapas desenvolvidas para as turmas de 2012 e 2013

\begin{tabular}{|c|c|c|c|}
\hline Etapas & $\begin{array}{c}\text { Turma } \\
2012 \\
\text { Docente } \\
\text { A }\end{array}$ & $\begin{array}{c}\text { Turma 1 } \\
(2013) \\
\text { Docente } \\
\text { B }\end{array}$ & $\begin{array}{c}\text { Turma } 2 \\
\text { (2013) } \\
\text { Docente } \\
\text { A }\end{array}$ \\
\hline \multicolumn{4}{|c|}{ Planejamento do ensino-aprendizagem } \\
\hline i) Primeira versão dos Mapas Conceituais & $\mathbf{R}$ & $\mathbf{R}$ & $\mathbf{R}$ \\
\hline ii) Inventário do ILS - Index of Learning Styles & $\mathbf{R}$ & $\mathbf{R}$ & $\mathbf{R}$ \\
\hline iii) Classificador de Temperamentos & $\mathbf{R}$ & $\mathbf{R}$ & $\mathbf{R}$ \\
\hline iv) Taxonomia dos objetivos educacionais de Bloom & $\mathbf{R}$ & NR & $\mathbf{R}$ \\
\hline \multicolumn{4}{|c|}{ Ensino-aprendizagem - Avaliação do processo } \\
\hline i) Recursos de ensino-aprendizagem em sala de aula & $\mathbf{R}$ & NR & $\mathbf{R}$ \\
\hline ii) Caracterização dos estilos das aulas & $\mathbf{R}$ & $\mathbf{R}$ & $\mathbf{R}$ \\
\hline iii) Aprendizagem ativa - Metodologia da Problematização & $\mathbf{R}$ & NR & $\mathbf{R}$ \\
\hline $\begin{array}{l}\text { iv) Construção da segunda e terceira versões dos mapas } \\
\text { conceituais }\end{array}$ & $\mathbf{R}$ & $\mathbf{R}$ & $\mathbf{R}$ \\
\hline \multicolumn{4}{|c|}{ Ensino-aprendizagem - Avaliação do Produto } \\
\hline Comparação entre média final e mapas conceituais & $\mathbf{R}$ & $\mathbf{R}$ & $\mathbf{R}$ \\
\hline
\end{tabular}

Legenda: R - Realizado e NR - Não realizado.

Vale ressaltar que a Turma de 2012 e a Turma 2 de 2013 ficaram sob responsabilidade do mesmo docente (Docente A).

A seguir estão descritas cada uma das etapas que foram conduzidas no procedimento experimental deste trabalho. Vale ressaltar que este procedimento foi posto em prática nos anos letivos de 2012 e 2013 e que ocorreram ligeiras diferenças entre os anos letivos.

\subsection{Planejamento do ensino-aprendizagem}

De maneira geral, o objetivo principal desta etapa foi a identificação de: $l$ ) organizadores prévios; ii) preferências de aprendizagem dos participantes da disciplina; iii) perfis de personalidade; e iv) resultados de aprendizagem pretendidos. Do ponto de vista instrumental, envolveria, respectivamente:

i) O Software IHMC - CmapTools, na construção da primeira versão dos Mapas Conceituais, elaborados de acordo com Novak (2003) e conforme a Teoria da Aprendizagem Significativa de Ausubel (1980);

ii) Inventário do ILS - Index of Learning Styles, de Felder e Soloman (2004);

iii) Classificador de Temperamentos, segundo Keirsey e Bates (1984) e Kuri (2004); 
iv) Taxonomia de Bloom (1972).

Cabe mencionar que as atividades envolvidas nesta caracterização são regularmente realizadas na disciplina em questão. Os organizadores prévios e as preferências de aprendizagem servem como referência para a elaboração das aulas expositivas e de outras atividades. Já o conhecimento dos perfis de personalidade serve de base para a formação de equipes de trabalho heterogêneas e não necessariamente constituídas por vínculos pessoais pré-existentes. Os itens $i$ e $i v$, no entanto, devem ser objeto de alguns esclarecimentos adicionais, que constarão da seção de resultados.

\subsection{Ensino-aprendizagem - Avaliação do processo}

O objetivo principal desta etapa foi avaliar os procedimentos adotados ao longo das atividades da disciplina. Os alunos foram conduzidos a adquirir domínio conceitual, estabelecer relações entre conceitos, identificar dados relevantes, fazer juízo de qualidade e tomar decisões. Os três últimos procedimentos configuram o agir ou criar algo sob o ponto de vista da resolução de um problema, sendo o último deles considerado um processo cognitivo de ordem superior. A etapa envolveu as seguintes atividades: I) aplicação de recursos de ensino-aprendizagem em sala de aula (Minute Papers, perguntas em classe e tarefas em duplas, em classe); ii) caracterização dos estilos das aulas; iii) uso de recursos de aprendizagem ativa - metodologia da problematização; e iv) segunda e terceira versões dos mapas conceituais, que foram elaboradas nesta etapa do desenvolvimento do trabalho. Do ponto de vista instrumental, envolveu os itens e procedimentos descritos na sequência (com exceção do item iv, que corresponde ao item $i$ de 3.1 e ao item 3.3).

\subsubsection{Recursos de ensino-aprendizagem em sala de aula}

Compreendeu as aulas expositivas, os Minute Papers, perguntas em classe e tarefas em duplas em classe. O pesquisador acompanhou e descreveu todas as atividades, tarefas e recursos utilizados pelo docente nas aulas. Estas descrições são a base dos resultados que serão apresentados na seção 4.2.1.

\subsubsection{Caracterização dos estilos das aulas}

A finalidade deste procedimento foi obter os estilos das aulas e compará-las com as preferências de aprendizagem dos alunos, de acordo com o item ii da seção 3.1 de 
Planejamento do Ensino-aprendizagem. A finalidade desta comparação era manter alinhadas as aulas expositivas com as preferências de aprendizagem da maioria dos alunos. A caracterização dos estilos das aulas, compreendeu a aplicação do instrumento proposto por Silva Junior e Rodrigues da Silva (2012 e 2013a). Este instrumento foi aplicado pelo menos cinco vezes ao longo do semestre, sempre relacionado a um determinado conjunto de aulas.

\subsubsection{Aprendizagem ativa - Metodologia da problematização}

Foi usada como ferramenta para o aprimoramento de competências e habilidades por meio da resolução de problemas. A metodologia da problematização foi desenvolvida conforme Berbel (1998) e contou com o sistema online Tidia-Ae como plataforma de suporte.

\subsection{Ensino-aprendizagem - Avaliação do Produto}

A meta principal desta etapa foi acompanhar e avaliar a aquisição de competências e habilidades, por parte dos alunos, em relação aos conteúdos relativos à disciplina. Os mapas conceituais construídos nas seções 3.1 e 3.2 foram analisados. Os resultados serviram de base para atestar níveis de domínio conceitual, domínio de relação conceitual e domínio procedimental. Foram estabelecidos os seguintes critérios de análise dos mapas, adaptados de Moreira e Masini (1982), Souza (2004), Cantú (2005), Ruiz-Moreno et al. (2007), Stange Lopes (2007), Tavares e Luna (2007), Corrêa (2009), Souza e Boruchovitch (2010a, b e c):

- Características comuns nas versões dos mapas conceituais - CCM

- Problemas recorrentes - PBR;

- Conceitos introduzidos - COI;

- Importância dos conceitos introduzidos - ICOI;

- Evolução nas três versões dos mapas conceituais - EVMC;

- Dificuldade para a construção dos mapas conceituais - DCMC;

- Conceitos preservados nas três versões dos mapas conceituais - CPMC;

- Relação entre valores atribuídos ao mapa conceitual final e à média final - RMCMF.

Além de acompanhar a evolução conceitual, domínio conceitual e domínio procedimental dos alunos, foi objetivo desta etapa estabelecer uma relação entre a versão final do mapa construído por cada aluno e sua média final na disciplina. Com base nesta comparação foi possível estabelecer uma avaliação do processo de ensino-aprendizagem mais dinâmica e 
fidedigna. Ao comparar o mapa final de cada aluno com sua média global é possível avaliar, de forma mais abrangente, o processo de aquisição de competências e habilidades.

Também foi solicitado que os alunos respondessem nove questões referentes à sua percepção com o uso dos mapas conceituais (ANEXO C - Questões 21 a 29). Estas questões foram aplicadas ao final da disciplina, somente para a Turma 2 de 2013, por meio de um formulário online.

\subsection{Conclusão do Capítulo}

Os procedimentos realizados neste trabalho de pesquisa estão resumidos na Figura 3.1. Sua análise fornece uma dimensão da complexidade envolvida nas diversas atividades realizadas, tanto dentro como fora de sala de aula. As três etapas do método de pesquisa foram planejadas e executadas de acordo com as diretrizes curriculares nacionais para cursos de engenharia, além de estarem alinhadas com as resoluções institucionais que regem os cursos de graduação da universidade onde ocorreram os experimentos. Dentro daquilo que era possível adaptar, modificar ou acrescentar ao plano de ensino da disciplina Planejamento e Análise de Sistemas de Transportes, em termos de ensino-aprendizagem, tudo foi devidamente planejado para gerar um ambiente o mais representativo possível da realidade que os alunos encontrarão no futuro profissional.

Apesar de todo o cuidado e critério em termos de métodos e instrumentos aplicados na pesquisa, ainda assim muitos experimentos não puderam ser conduzidos da forma mais "realista" ou representativa. Desenvolver experimentos de ensino-aprendizagem em cursos de graduação em engenharia no Brasil, que possuem seus currículos considerados tradicionais, pode gerar dificuldades extras e que precisam ser consideradas nas etapas de análises dos resultados e conclusões a respeito da pesquisa. Qualquer ação que não esteja alinhada com a legislação vigente no país e/ou ao regimento interno dos cursos de graduação da universidade pode, por exemplo, ser contestada pelos alunos, pela instituição ou ainda outras entidades. 


\section{Método}

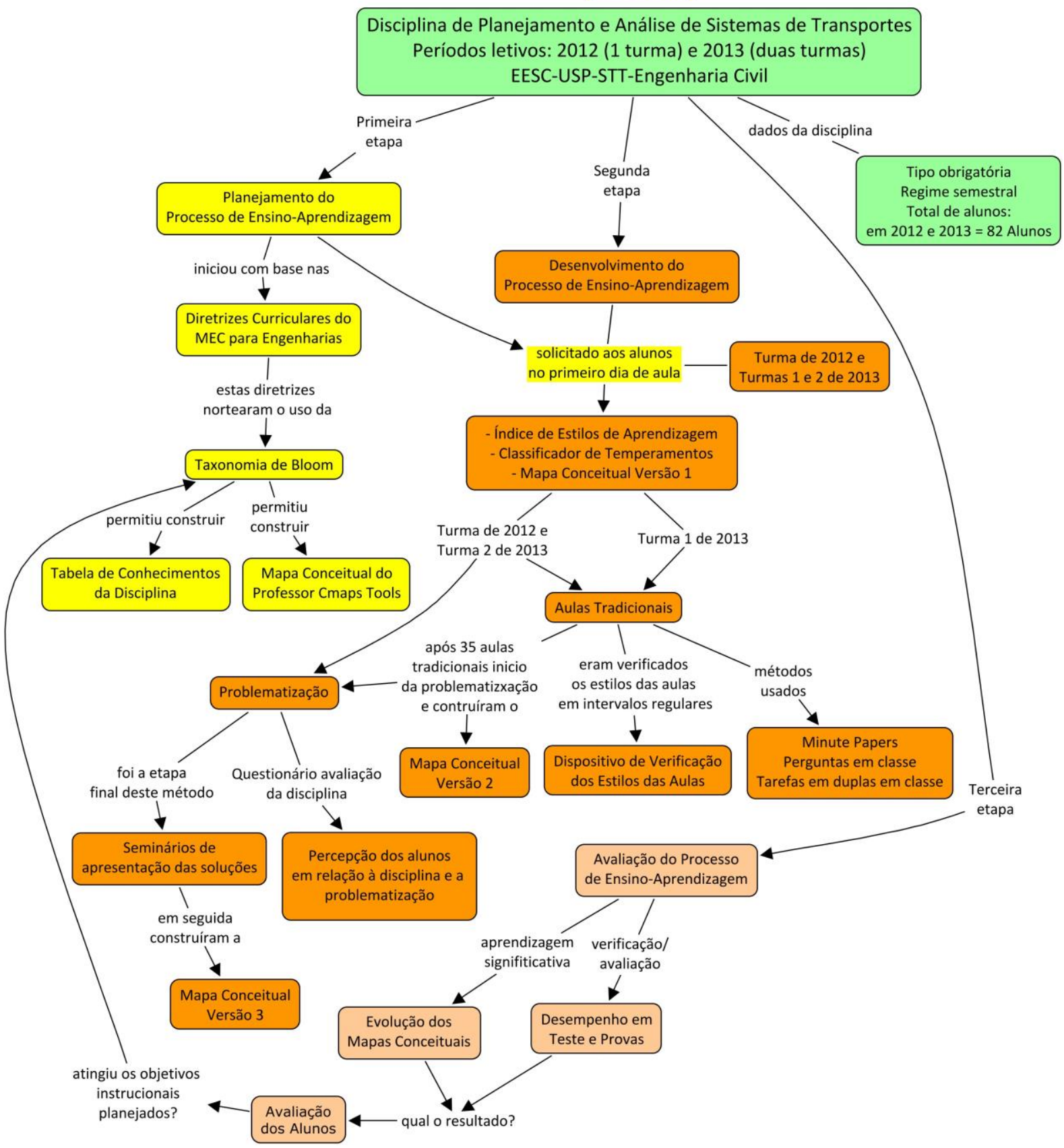

Figura 3.1: Resumo do método aplicado nesta pesquisa. 


\section{RESULTADOS E ANÁLISES}

A seguir são apresentados os resultados do estudo, conforme as etapas previstas no método. Estes resultados estão divididos em três partes: 1) Planejamento de ensinoaprendizagem; ii) Ensino-aprendizagem - Avaliação do processo; e iii) Ensino-aprendizagem - Avaliação do produto: mapas conceituais. Além disso, os resultados estão apresentados conforme os anos letivos de 2012 e 2013, sendo que em 2013 foram analisadas duas turmas (Turma 1 e Turma 2).

\subsection{Planejamento de ensino-aprendizagem}

Esta etapa envolveu quatro itens que foram efetivamente usados no planejamento das atividades desta pesquisa. São aqueles que dizem respeito à identificação de organizadores prévios (primeira versão do mapa conceitual), preferências de aprendizagem, perfis de personalidade dos participantes da disciplina e à construção dos resultados de aprendizagem pretendidos por meio da Taxonomia dos objetivos educacionais de Bloom (itens $i$, ii, iii e iv da seção 3.1, respectivamente). No caso do item $i$, além do que é discutido em 4.1.1, os mapas conceituais que também foram usados na análise da evolução do processo de ensino-aprendizagem, são apresentados na seção 4.3.

\subsubsection{Organizadores prévios}

Estes organizadores foram obtidos a partir da primeira versão dos mapas conceituais construídos pelos alunos. A partir deles foi possível identificar o que os alunos já sabiam, de forma geral, sobre planejamento de transportes. Estes organizadores serviram de base para o planejamento das atividades da disciplina.

$\mathrm{Na}$ Tabela 4.1 são apresentados os organizadores prévios extraídos da primeira versão dos mapas conceituais elaborados pelos alunos. Ficou claro que os alunos possuíam um relativo domínio conceitual sobre o tema sistema de transportes, principalmente sobre questões relacionadas ao meio ambiente; poluição e sustentabilidade. Estes aspectos estão fortemente ligados aos chamados efeitos indesejáveis que são gerados pelos sistemas de transportes. Estes organizadores prévios também foram usados como conceitos-chave juntamente com outros conceitos que foram extraídos do mapa conceitual confeccionado pelo professor da Turma de 2012 e Turma 2 de 2013. 
Tabela 4.1: Organizadores prévios extraídos da primeira versão dos mapas conceituais

\title{
Organizadores Prévios
}

\author{
Análise \\ Demanda \\ Efeitos indesejáveis \\ Meio ambiente \\ Modos de transportes \\ Oferta \\ Planejamento \\ Poluição \\ Projetos \\ Qualidade \\ Sistemas público e privado \\ Sustentabilidade
}

\subsubsection{ILS - Preferências de aprendizagem}

O ILS, inventário desenvolvido por Felder e Soloman (2004), foi utilizado para caracterizar os estilos (ou preferências) de aprendizagem dos alunos. A partir destes resultados foi possível obter uma caracterização geral das turmas, conforme apresentado na Figura 4.1 e 4.2. Neste caso, os valores que constam do centro das matrizes representam as quantidades de alunos que se situam em uma situação específica relativa aos estilos de aprendizagem e aos perfis de personalidade. As quantidades que ficam no centro da escala do índice de estilos de aprendizagem (valores iguais a 1 e 3 ), na horizontal, representam os indivíduos que possuem preferências de aprendizagem equilibradas com relação à dimensão considerada. Conforme o modelo de Felder e Silverman (1988), os alunos que estão nesta faixa do ILS podem se beneficiar de atividades que enfoquem os dois estilos de cada dimensão. Os demais entrevistados encontram-se em uma faixa de escores especificada como de moderado (5 e 7) a forte (9 e 11). Nesta última situação, em particular, os alunos preferem participar de processos que estejam direcionados a um dos extremos de cada dimensão. 


\subsubsection{Perfis de Personalidade}

O classificador de temperamentos de Keirsey e Bates (1984) foi usado para caracterizar o perfil de personalidade dos alunos, base para a montagem das equipes nas atividades relativas à metodologia da problematização. As equipes foram montadas de forma a possuírem a maior variedade possível de perfis de personalidade. Nas Figuras 4.1 e 4.2 aparecem também detalhadas as quantidades de indivíduos de acordo com os perfis de personalidade. Tanto as preferências de aprendizagem quanto os perfis de personalidade dos alunos estão separados de acordo com o ano letivo em que foi realizado o experimento. Com relação ao ano de 2013, os alunos foram divididos em Turma 1 e 2 . Vale ressaltar que a Turma 1 não desenvolveu a atividade de aprendizagem ativa.

Os perfis de personalidade dos alunos são predominantemente Ativo-Extrovertido (Q1 Quadrante 1, Figura 4.1 (a)), Sensorial-Sensorial (Q1 - Quadrante 1, Figura 4.1 (b)), VisualRacional (Q1 - Quadrante 1, Figura 4.2 (c)) e Sequencial/Global-Judicativo (Q1 e Q2 Quadrantes 1 e 2, Figura 4.2 (d)). Na Tabela 4.2 tem-se a distribuição dos perfis de personalidade dos integrantes de cada grupo na metodologia da problematização para a Turma de 2012 e para a Turma 2 de 2013.

No ano letivo de 2013 os alunos tiveram a oportunidade de escolher em qual turma iriam cursar a disciplina de Planejamento e Análise de Sistemas de Transportes. Este processo surgiu levando em conta a hipótese de que a escolha poderia evidenciar ligeiras diferenças, em termos de preferências de aprendizagem e perfis de personalidade, entre as Turmas $1 \mathrm{e}$ 2. Porém, conforme as Figuras 4.1 e 4.2, não há diferenças significativas entre as turmas. Desta forma, o processo de escolha por parte dos alunos foi feito com base em critérios que não levaram em consideração as suas características de perfil de personalidade e nem as preferências de aprendizagem. 


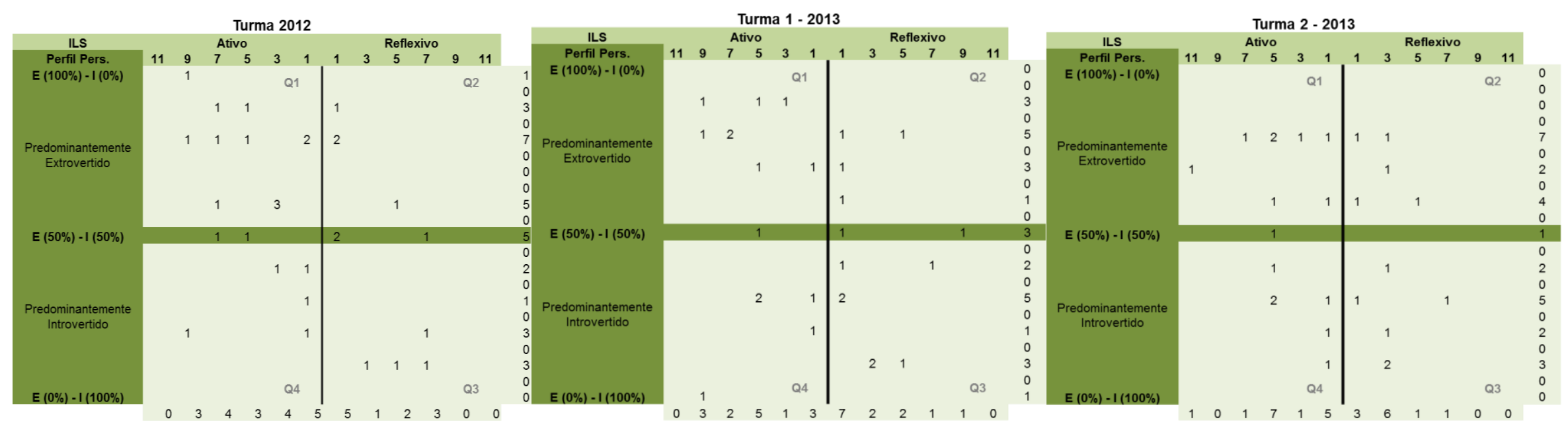

(a)

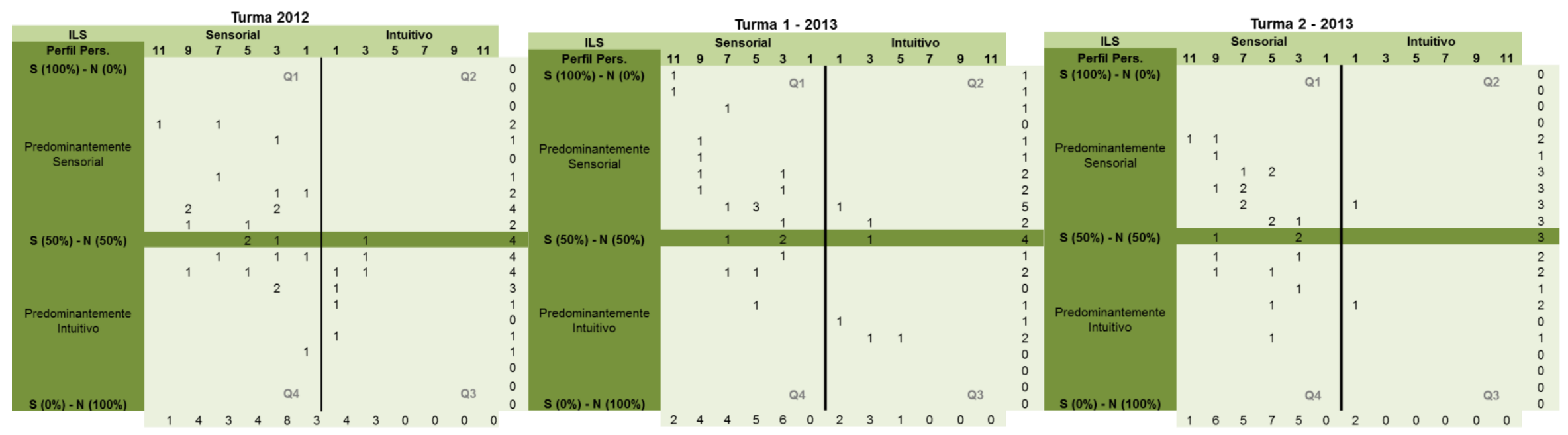

(b)

Figura 4.1: Distribuição geral das turmas em função do ILS - Index of Learning Styles (Dimensões ativo-reflexivo e sensorial-intuitivo) e do Classificador de Temperamentos (Dimensões extrovertido-introvertido e sensorial-intuitivo) 


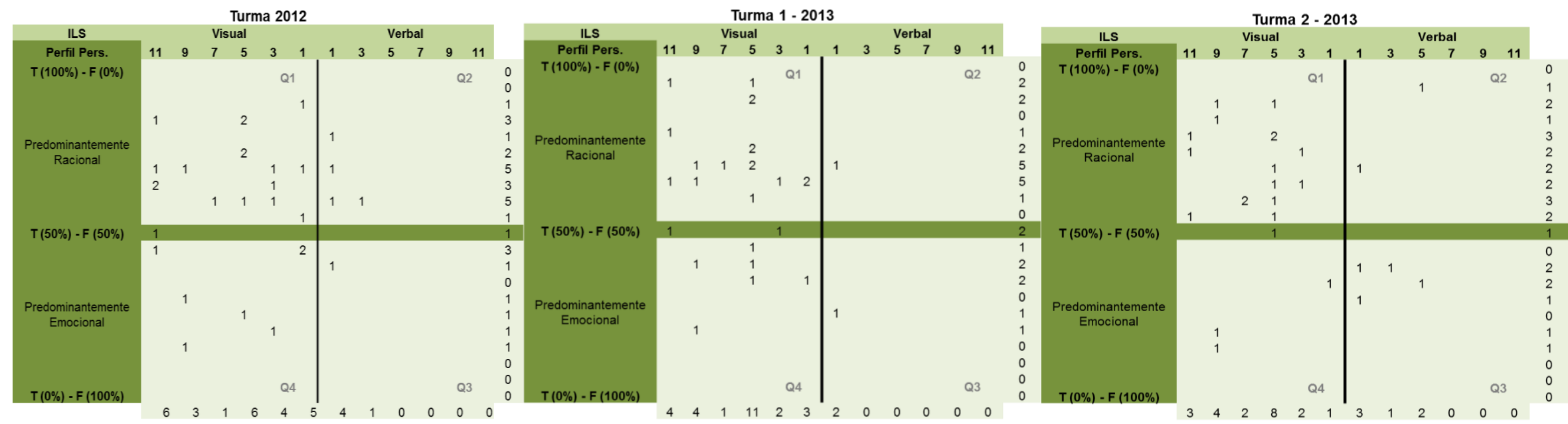

(c)

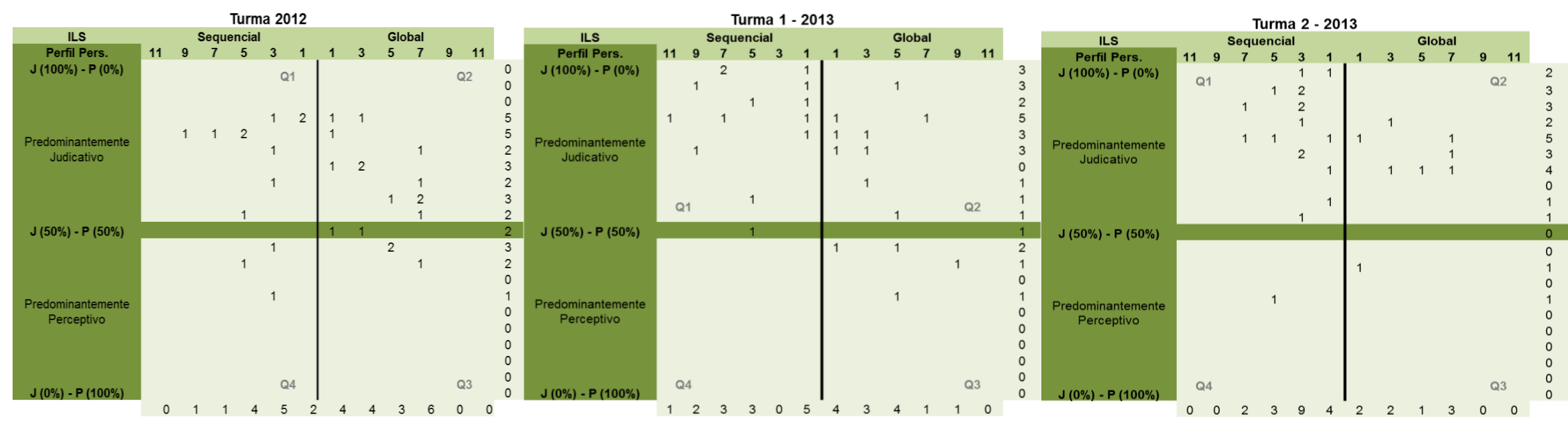

(d)

Figura 4.2: Distribuição geral das turmas em função do ILS - Index of Learning Styles (Dimensões visual-verbal e sequencial-global) e do Classificador de Temperamentos (Dimensões racional-emocional e judicativo-perceptivo) 
Os grupos de trabalho na metodologia da problematização foram organizados de modo a possuírem os mais variados tipos de perfis de personalidade, conforme a Tabela 4.2. Este procedimento tentou reproduzir nesta atividade de ensino-aprendizagem o ambiente de trabalho do meio profissional. Desta forma, os alunos puderam conviver com pessoas que possuíam características de personalidade muito diferentes das suas e, a partir deste convívio, puderam conhecer um pouco mais os outros e a si mesmo.

Tabela 4.2: Tipos básicos de cada grupo - Turmas 2012 e Turma 2 de 2013

\begin{tabular}{|c|c|c|c|c|c|c|c|c|c|c|c|}
\hline \multirow{2}{*}{\multicolumn{2}{|c|}{$\begin{array}{c}\text { Perfis de Personalidade } \\
\text { Quatro tipos básicos de temperamento e os } \\
\text { dezesseis subtipos }\end{array}$}} & \multicolumn{5}{|c|}{ Grupos - 2012} & \multicolumn{5}{|c|}{ Grupos - 2013} \\
\hline & & A & B & C & D & $\mathbf{E}$ & A & B & C & D & $\mathbf{E}$ \\
\hline \multirow{4}{*}{$\begin{array}{l}\text { Realista } \\
\text { Judicativo } \\
\text { (SJ) }\end{array}$} & ESFJ(SJ), extrovertido (E), sensível (F) & - & 1 & - & 1 & - & - & - & - & 1 & 1 \\
\hline & ISFJ(SJ), introvertido (I), sensível (F) & 1 & - & - & - & - & - & 1 & 1 & - & - \\
\hline & ESTJ (SJ), extrovertido (E), racional (T) & 1 & 1 & 1 & 2 & 2 & 2 & - & 1 & 2 & 2 \\
\hline & ISTJ(SJ), introvertido (I), racional (T) & 1 & - & 1 & - & 1 & 2 & 1 & 1 & - & 1 \\
\hline \multirow{4}{*}{$\begin{array}{l}\text { Realista } \\
\text { Perceptivo } \\
\quad \text { (SP) }\end{array}$} & $\operatorname{ESFP}(\mathrm{SP})$, extrovertido(E),sensível (F) & - & 1 & - & - & - & - & 1 & - & - & - \\
\hline & ISFP(SP), introvertido (I), sensível (F) & \multicolumn{5}{|c|}{ Inexistente } & \multicolumn{5}{|c|}{ Inexistente } \\
\hline & ESTP (SP), extrovertido $(E)$, racional $(T)$ & - & - & 1 & - & - & - & 1 & - & - & - \\
\hline & ISTP (SP), introvertido (I), racional (T) & 1 & - & - & - & - & & & ist & & \\
\hline \multirow{4}{*}{$\begin{array}{l}\text { Intuitivo } \\
\text { Racional } \\
\quad \text { (NT) }\end{array}$} & ENTJ (NT), extrovertido (E), judicativo (J) & 1 & 1 & - & - & 1 & 1 & - & 1 & - & - \\
\hline & INTJ (NT), introvertido (I), judicativo (J) & - & 1 & - & 1 & - & - & - & - & 1 & 1 \\
\hline & ENTP (NT), extrovertido (E), perceptivo $(P)$ & - & 1 & 1 & - & - & \multicolumn{5}{|c|}{ Inexistente } \\
\hline & INTP (NT), introvertido (I), perceptivo (P) & - & - & 1 & - & 1 & \multicolumn{5}{|c|}{ Inexistente } \\
\hline \multirow{4}{*}{$\begin{array}{l}\text { Intuitivo } \\
\text { Sensorial } \\
\quad \text { (NF) }\end{array}$} & ENFJ (NF), extrovertido (E), judicativo (J) & 1 & - & - & 2 & 1 & \multicolumn{5}{|c|}{ Inexistente } \\
\hline & INFJ (NF), introvertido (I), judicativo (J) & - & - & 1 & - & - & - & & 1 & 1 & - \\
\hline & ENFP (NF), extrovertido (E), perceptivo (P) & \multicolumn{5}{|c|}{ Inexistente } & \multicolumn{5}{|c|}{ Inexistente } \\
\hline & INFP(NF), introvertido (I), perceptivo (P) & \multicolumn{5}{|c|}{ Inexistente } & \multicolumn{5}{|c|}{ Inexistente } \\
\hline
\end{tabular}

\subsubsection{Resultados de aprendizagem}

A taxonomia dos objetivos educacionais desenvolvida por Bloom et al. (1972), as Diretrizes Curriculares Nacionais dos Cursos de Engenharia e os objetivos programados institucionalmente para a disciplina Planejamento e Análise de Sistemas de Transportes foram os elementos-chave para o desenvolvimento da tabela de conhecimentos geral apresentada na Figura 4.3. A tabela de conhecimentos passou a nortear o processo de ensino-aprendizagem da disciplina e previa tarefas muito além das atividades tradicionais realizadas em sala de aula, ou seja, atividades de aprendizagem ativa na forma de metodologia da problematização. 


\begin{tabular}{|c|c|c|c|c|c|c|c|}
\hline \multicolumn{8}{|c|}{ Disciplina de Planejamento e Análise de Sistemas de Transportes - Graduação em Engenharia Civil } \\
\hline \multirow{3}{*}{ 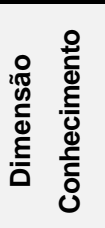 } & \multicolumn{6}{|c|}{ Dimensão Processo Cognitivo } & \multirow{3}{*}{ 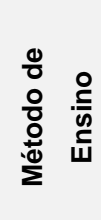 } \\
\hline & \multicolumn{2}{|c|}{ Conhecimento } & \multirow{2}{*}{$\begin{array}{c}\text { Competência } \\
\text { Aplicar... }\end{array}$} & \multicolumn{3}{|c|}{ Habilidade } & \\
\hline & Lembrar... & Entender... & & Analisar... & Avaliar... & Criar... & \\
\hline 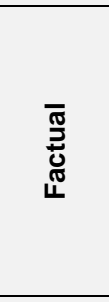 & $\begin{array}{l}\text {... os principais conceitos relacionados } \\
\text { com os aspectos econômicos e sociais } \\
\text { dos sistemas de transporte } \\
\ldots \text { os principais aspectos relacionados } \\
\text { com os impactos ambientais do sistema } \\
\text { de transporte } \\
\ldots \text { os principais conceitos ligados à } \\
\text { tarifação de sistemas de transporte e à } \\
\text { avaliação de projetos de transporte }\end{array}$ & & & & & & 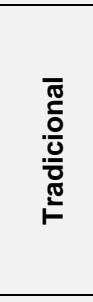 \\
\hline 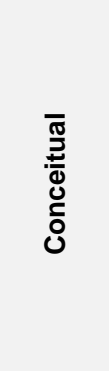 & & $\begin{array}{l}\text {... como os aspectos } \\
\text { econômicos e sociais } \\
\text { influenciam no } \\
\text { planejamento, projeto e } \\
\text { operação de sistemas de } \\
\text { transporte } \\
\ldots \text { como os aspectos } \\
\text { ambientais influenciam na } \\
\text { avaliação, planejamento, } \\
\text { projeto e operação de } \\
\text { sistemas de transporte }\end{array}$ & & & & & 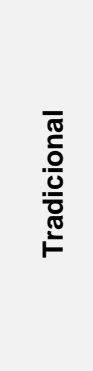 \\
\hline 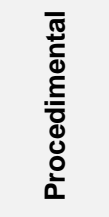 & & & $\begin{array}{l}\text {... modelo sequenciais em } \\
\text { sistemas de transportes } \\
\text {... tarifação no } \\
\text { planejamento, projeto e } \\
\text { operação de sistemas de } \\
\text { transporte }\end{array}$ & $\begin{array}{l}\text {... projetos de } \\
\text { transporte }\end{array}$ & $\begin{array}{l}\ldots \text { projetos de } \\
\text { transporte }\end{array}$ & & 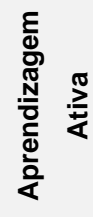 \\
\hline 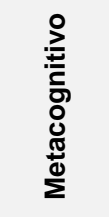 & & & & & & $\begin{array}{l}\text {... solução } \\
\text { para um } \\
\text { problema de } \\
\text { transporte } \\
\text { urbano }\end{array}$ & 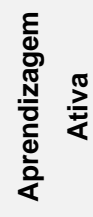 \\
\hline
\end{tabular}

Figura 4.3: Tabela de conhecimentos para a disciplina de Planejamento e Análise de Sistemas de Transportes 
Os objetivos educacionais propostos na tabela de conhecimentos da Figura 4.3 foram construídos de forma a atender às perspectivas profissionais vigentes, tais como: multidisciplinaridade e transdiciplinaridade dos conteúdos envolvidos; trabalho em equipes para alcançar objetivos concretos e aqueles relacionados às competências básicas de um engenheiro civil atuando em temas da engenharia de transportes. Visa, desta forma, oferecer formação sociocultural e tecnológica.

\subsection{Ensino-aprendizagem - Avaliação do processo}

Nesta seção serão apresentados os resultados relativos aos itens: $l$ ) aplicação de recursos de ensino-aprendizagem em sala de aula (Minute Papers, perguntas em classe e tarefas em duplas em classe); ii) caracterização dos estilos das aulas e iii) uso de recursos de aprendizagem ativa - metodologia da problematização. Embora o item iv da seção 3.2 (também citado em 3.3) tenha sido realizado durante as aulas expositivas, vale ressaltar que os resultados relativos à primeira, segunda e à terceira versão dos mapas conceituais serão apresentados na seção 4.3. As médias finais obtidas pelos alunos em provas, testes e demais atividades foram usadas especificamente para fins de comparação com os mapas conceituais na análise que será apresentada na seção 4.3.

\subsubsection{Recursos de ensino-aprendizagem em sala de aula}

Nesta seção serão apresentados os procedimentos usados em sala de aula durante as atividades que faziam parte da disciplina. Na Tabela 4.3 estão os tipos de recursos que os professores usaram com o objetivo de gerar a participação efetiva dos alunos. O docente sempre buscou interação com os alunos, ou seja, os mesmos eram solicitados regularmente durante as aulas a expressar suas percepções, ideias e comentários a respeito dos conteúdos. Isto tornava a aula dinâmica e evitava dispersão.

As aulas expositivas aconteciam em dois dias de cada semana e em cada dia havia 110 minutos de aulas. Nestas aulas eram apresentados os conceitos relativos à disciplina e os procedimentos aplicados estavam alinhados às dimensões do conhecimento (factual e conceitual) e do processo cognitivo (lembrar e entender) da taxonomia dos objetivos educacionais de Bloom. Eram usados recursos tradicionais na lousa, explanações orais pelo docente e recursos audiovisuais informatizados. Além disso, foram aplicadas atividades dirigidas em laboratório de informática. 
Os Minute Papers foram aplicados de forma não regular ao longo dos dois anos letivos. Geralmente eram solicitados aos alunos em semanas anteriores às provas e testes. $\mathrm{O}$ objetivo era identificar quais conteúdos os alunos tinham mais vivos na memória e aqueles que precisariam ser melhor esclarecidos nas aulas futuras.

As perguntas em classe eram parte constante das aulas expositivas ou atividades dirigidas em laboratório de informática, feitas pelo docente sobre os conteúdos da aula em questão ou até mesmo de aulas passadas. Eram perguntas objetivas, que geralmente envolviam respostas literais.

Tabela 4.3: Recursos de ensino-aprendizagem usados em sala de aula

\begin{tabular}{|c|c|c|c|c|}
\hline \multirow{3}{*}{ Recurso } & \multirow{3}{*}{ Descrição } & \multicolumn{3}{|c|}{ Turmas } \\
\hline & & \multirow{2}{*}{2012} & \multicolumn{2}{|c|}{2013} \\
\hline & & & $\begin{array}{c}\text { Turma } \\
1\end{array}$ & $\begin{array}{c}\text { Turma } \\
2\end{array}$ \\
\hline $\begin{array}{l}\text { Aulas } \\
\text { expositivas }\end{array}$ & $\begin{array}{l}\text { Apresentaram os conceitos relativos à disciplina, } \\
\text { através de recursos tradicionais na lousa ou } \\
\text { audiovisuais informatizados, atividades dirigidas em } \\
\text { laboratório de informática e explanações orais pelo } \\
\text { docente. }\end{array}$ & $\mathrm{R}$ & $\mathrm{R}$ & $\mathrm{R}$ \\
\hline $\begin{array}{l}\text { Minute } \\
\text { Papers }\end{array}$ & $\begin{array}{l}\text { Tinham como objetivo identificar quais conteúdos } \\
\text { tratados nas aulas expositivas eram considerados } \\
\text { mais úteis ou importantes e quais ficaram mais } \\
\text { vivos na memória dos alunos. Esta técnica permitia } \\
\text { ao professor tratar de assuntos recorrentes que } \\
\text { eram citados pelos alunos. }\end{array}$ & $\mathrm{R}$ & NR & $\mathrm{R}$ \\
\hline $\begin{array}{l}\text { Perguntas } \\
\text { em classe }\end{array}$ & $\begin{array}{l}\text { Perguntas diretas e breves, feitas pelo docente. As } \\
\text { perguntas eram relativas aos conteúdos da aula em } \\
\text { questão ou de aulas passadas. }\end{array}$ & $\mathrm{R}$ & $\mathrm{R}$ & $\mathrm{R}$ \\
\hline $\begin{array}{l}\text { Tarefas em } \\
\text { duplas em } \\
\text { classe }\end{array}$ & $\begin{array}{l}\text { As tarefas correspondiam à resolução de pequenos } \\
\text { problemas ou questionamentos mais práticos } \\
\text { (construção de gráficos, resoluções de exercícios } \\
\text { matemáticos, construção de modelos matemáticos, } \\
\text { etc.). Os alunos trabalhavam em duplas e com um } \\
\text { tempo estipulado a priori pelo professor, algo em } \\
\text { torno de } 5 \text { a } 10 \text { minutos. Ao final deste tempo, eram } \\
\text { solicitados a apresentarem seus resultados. }\end{array}$ & $\mathrm{R}$ & $\mathrm{R}$ & $\mathrm{R}$ \\
\hline
\end{tabular}

Legenda: R - Realizado e NR - Não realizado.

As tarefas em dupla em classe abordavam partes mais específicas e envolviam soluções mais detalhadas do conteúdo da disciplina. Podia exigir que o aluno recorresse à lousa para apresentar a solução da tarefa, principalmente quando envolvia a realização de cálculos matemáticos ou construção de gráficos. Os alunos não se recusavam a participar e 
consideravam este procedimento como um incentivo ao aprendizado do conteúdo da disciplina.

\subsubsection{Caracterização dos estilos das aulas $x$ preferências de aprendizagem dos alunos}

O estilo das aulas foi avaliado conforme proposto por Silva Junior e Rodrigues da Silva (2012 e 2013a). Este procedimento permitiu comparar se as aulas expositivas atendiam às preferências de aprendizagem dos alunos. Os resultados do estilo de ensino dos professores para a Turma de 2012 e para as Turmas 1 e 2 de 2013 são apresentados nas Figuras 4.4a e 4.4b. A Turma de 2012 e a Turma 2 de 2013 ficaram sob responsabilidade do mesmo professor. Já a Turma 1 de 2013 ficou sob responsabilidade de outro docente. Os resultados estão reunidos da seguinte forma, para fins de comparação: $i$ ) estilos das aulas expositivas por turma (Figura 4.4a) e ii) estilos de aprendizagem por turma (Figura 4.4b).

Nas Figuras 4.4a e 4.4b pode-se observar que o estilo das aulas esteve, na maioria das vezes, alinhado com as preferências de aprendizagem majoritárias das respectivas turmas. Isto pode ter favorecido a participação dos alunos e o bom andamento das atividades. Vale ressaltar que o percentual de alunos que corresponde simultaneamente às dimensões Visual-Verbal, Ativo-Reflexivo, Sensorial-Intuitivo e Sequencial-Global (Figura 4.4b) pode se adaptar de forma satisfatória em atividades que estejam compreendidas nos dois extremos dessas dimensões.

A análise feita na Figura 4.4a serviu para atestar que não houve diferenças significativas entre os estilos das aulas dos docentes que ministraram a disciplinas de Planejamento e Análise de Sistemas de Transportes. Cabe mencionar que a Turma de 2012 e a Turma 2 de 2013 foram conduzidas pelo mesmo docente e a Turma 1 de 2013 foi conduzida por outro docente. O docente que ministrou aulas para a Turma de 2012 e para a Turma 2 de 2013, manteve o estilo das aulas. Talvez tenha havido uma ligeira diferença com relação à dimensão sequencial-global. 

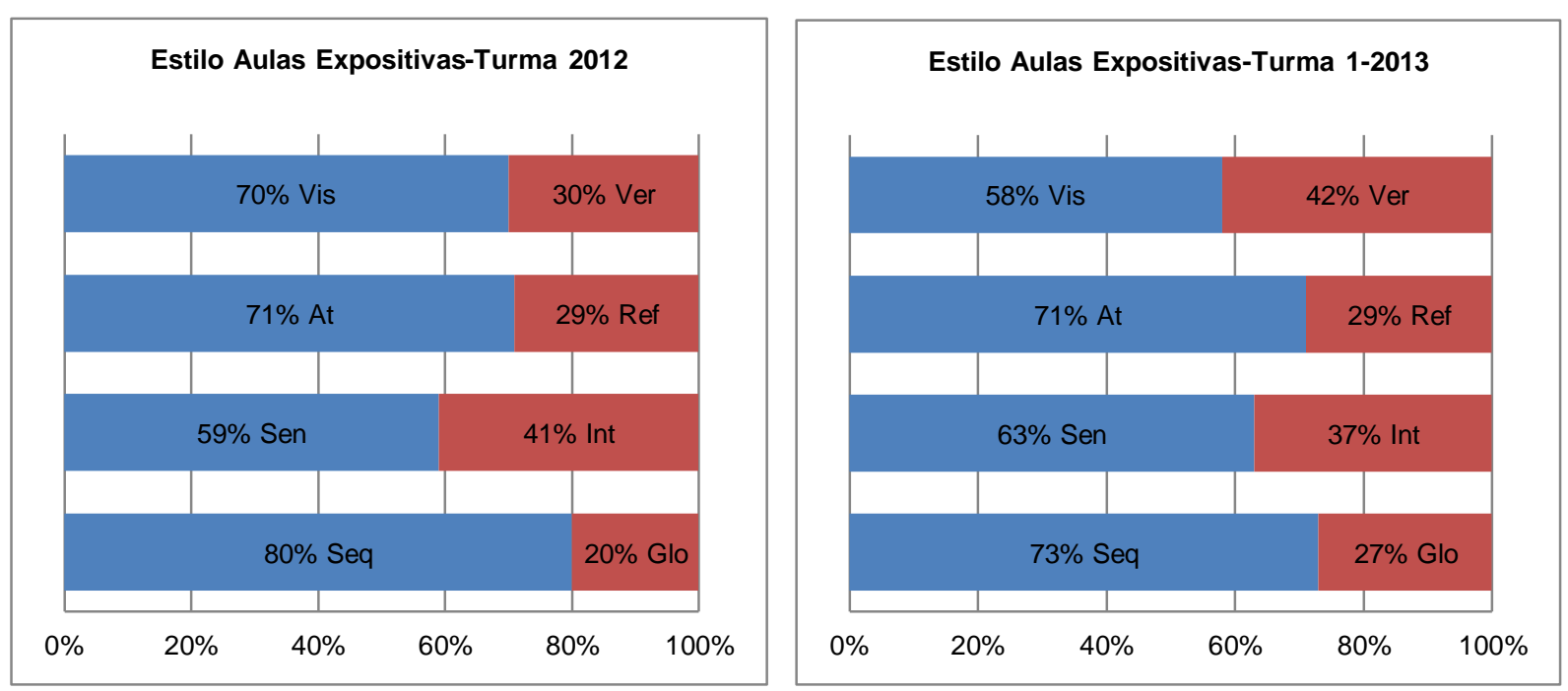

(a)
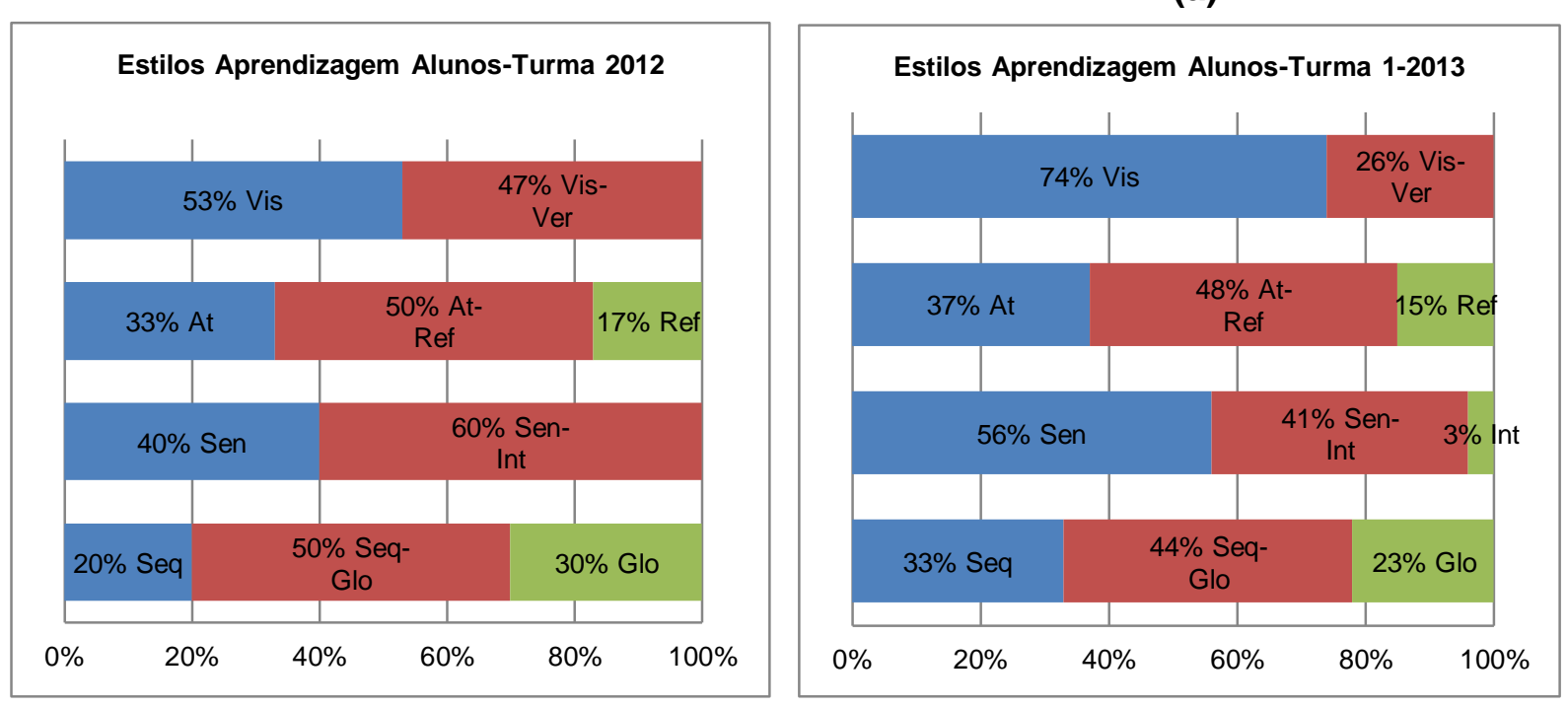

(b)
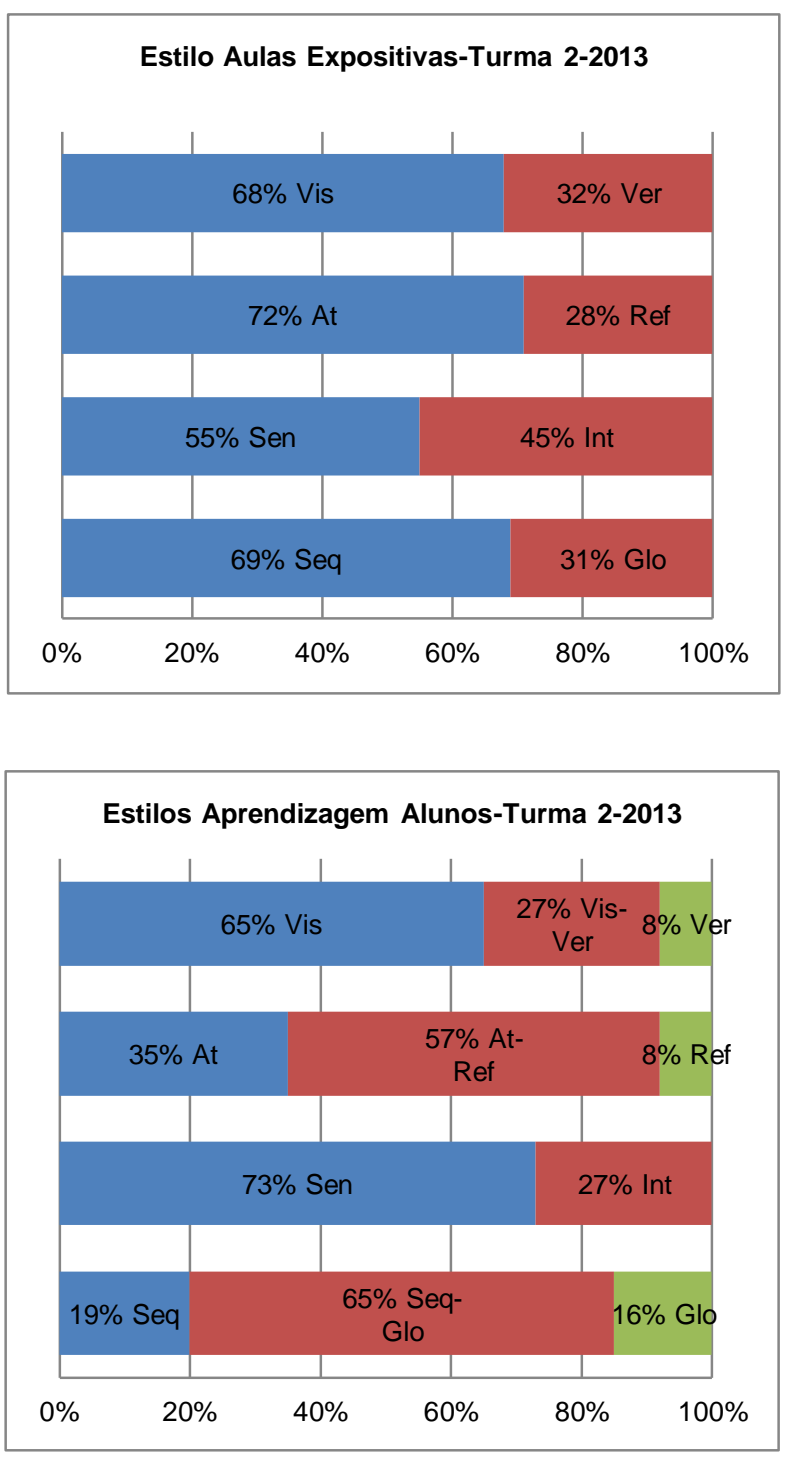

Figura 4.4: Estilo das aulas expositivas x preferências de aprendizagem dos alunos - Turma de 2012 e Turmas 1 e 2 de 2013 
Com relação aos estilos de aprendizagem, conforme a Figura 4.4b, pode-se atestar que de uma forma geral não há diferenças significativas entre os estilos das três turmas. Uma ligeira alteração talvez possa ser indicada na dimensão sequencial-global. Esta alteração parece estar mais inclinada para a situação em que os alunos encontram-se na zona de transição (sequencial-global), os quais não teriam problemas para se integrar de forma satisfatória em atividades que estejam compreendidas nos dois extremos dessas dimensões.

\subsubsection{Metodologia da problematização}

O uso da metodologia da problematização envolveu uma série de tarefas que estavam relacionadas à questão da mobilidade de pedestres e a moderação do tráfego de veículos automotores nas proximidades de um campus universitário. Pesquisas feitas pelos alunos da Turma de 2011 e da Turma 2 de 2013 da mesma disciplina serviram como referência inicial. Os procedimentos adotados nesta etapa da pesquisa envolveram basicamente 0 trabalho em equipe e o uso do ambiente colaborativo Tidia-Ae, que foi usado para dar suporte à metodologia da problematização. Este ambiente online gerencia cursos, atividades de ensino-aprendizado e possui ferramentas para auxiliar alunos, professores e tutores. $O$ Tidia-Ae também foi usado, nesta pesquisa, para a realização de testes, disponibilização de material didático e de bases de dados, compartilhamento de documentos, fórum de discussão, upload de relatórios e envio de mensagens.

No Tidia-Ae, para o caso específico desta pesquisa, foram conduzidos dois fóruns online com os alunos (Turma 2012 e Turma 2 - 2013). O Fórum 1 foi dividido em duas partes: i) a primeira parte correspondeu à etapa de formulação do problema que seria resolvido por meio de trabalho em equipe; e ii) na segunda parte foi feita a escolha da abordagem com maior viabilidade de desenvolvimento. Após estas duas etapas do Fórum 1, iniciaram-se as atividades de resolução de problema, de acordo com o que foi decidido na etapa de formulação do problema. O Fórum 2 compreendeu uma etapa de análise e avaliação dos dados obtidos para a resolução do problema formulado. Com base em dados coletados em 2011 e 2013, os alunos avaliaram qual a melhor forma de conduzir os trabalhos.

A seguir são apresentados os resultados relativos às respostas obtidas por meio de um questionário (ANEXO C - Questões 1 a 20) aplicado aos alunos que cursaram a disciplina de Planejamento e Análise de Sistemas de Transportes na Turma de 2012 e na Turma 2 de 2013. Este questionário teve como objetivo captar a percepção dos alunos em relação às atividades da metodologia da problematização. Os dados relativos à pesquisa que trata este 
trabalho foram obtidos especificamente nos anos de 2012 e 2013 (apenas Turma 2). Porém, serão também apresentados dados relacionados ao mesmo questionário aplicado entre os anos de 2006 a 2011. A finalidade de agrupar estes dados é para fins de registro e comparação.

Os questionários apresentados aos alunos ao longo dos anos de 2006 a 2013 são similares para fins de comparação, apesar de algumas modificações a partir de 2013, tais como: preenchimento em uma plataforma online; possibilidade de inserir comentários e a inclusão de nove questões relativas ao uso dos mapas conceituais. No anexo C (Questões 1 a 20) tem-se o questionário usado. Os resultados do questionário estão divididos em quatro temas, para fins de apresentação e análise: 1 ) percepção geral dos alunos em relação à disciplina (Figuras 4.5 a 4.8); ii) percepção dos alunos em relação ao formato da disciplina (Figuras 4.9 a 4.12); iii) opinião dos alunos em relação ao ambiente online Tidia-Ae (Figuras 4.13 a 4.16); e iv) avaliação dos alunos em relação a atividade de aprendizagem ativa na forma de metodologia da problematização (Figuras 4.17 a 4.20).

Com relação à percepção geral da disciplina por parte dos alunos, pode-se observar na Figura 4.5 que a grande maioria dos alunos considerou o conteúdo tratado na disciplina como interessante e útil. Os anos de 2007 e 2013 tiveram os maiores percentuais de alunos que consideraram a disciplina interessante e útil ao longo da série de resultados analisada.

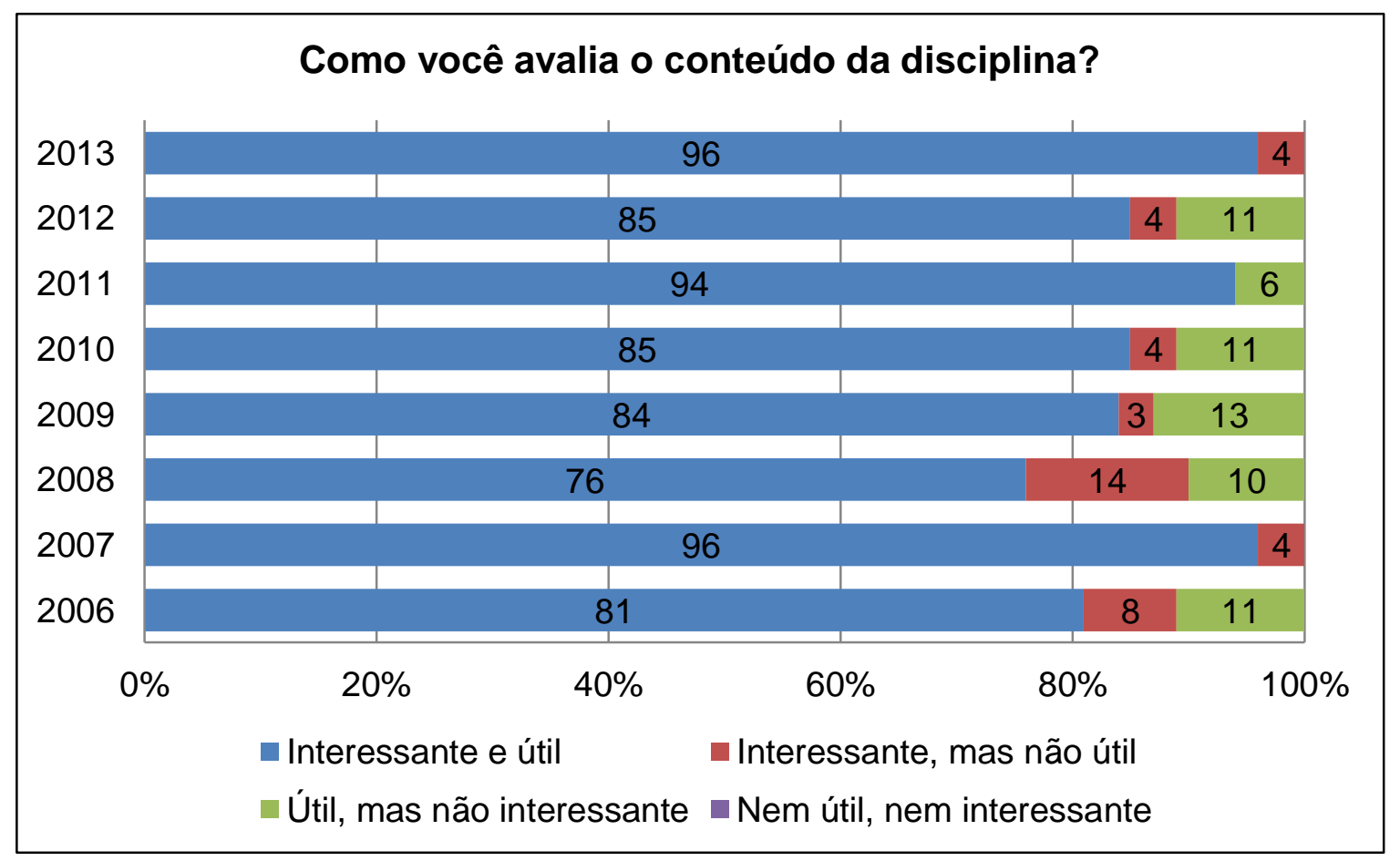

Figura 4.5: Avaliação do conteúdo disciplina 
A disciplina de Planejamento e Análise de Sistemas de Transportes possui conteúdos fortemente relacionados à análise de sistemas, estudos econômico-financeiros e avaliação ambiental. Desta forma, pode-se avaliar que estes temas sejam considerados interessantes e úteis no contexto atual, principalmente nas áreas urbanas. Além disso, os conteúdos da disciplina foram aplicados em vários procedimentos conduzidos na atividade de projeto ou metodologia da problematização.

Os processos de ensino-aprendizagem podem envolver uma série de técnicas e ferramentas que possuem várias finalidades, como, por exemplo, contribuição efetiva ao aprendizado de um conteúdo. Na disciplina considerada nesta pesquisa foram adotados vários procedimentos que tiveram como objetivo contribuir para o aprendizado dos temas abordados, tais como: exercícios em sala de aula; fórum por meio de uma plataforma online; atividades em grupo para resolução de problema; provas e testes. Desta forma, na Figura 4.6 observa-se que a realização de exercício em aula, atividades em grupo e provas foram consideradas as atividades que mais contribuíram para gerar aprendizagem dos conteúdos da disciplina, segundo a percepção dos alunos. Por outro lado, o fórum tem se mostrado a atividade menos receptiva pelos alunos. Esta menor receptividade também pode ser evidenciada pelas conversas com os alunos, principalmente nos anos de 2011 a 2013. A principal justificativa apresentada pelos alunos a esta menor receptividade foi a preferência deles em tratar as discussões ou explanações de forma presencial e oral, além da dificuldade de expressar-se literalmente na forma escrita o que gostariam de apresentar durante as discussões do fórum.

Outra questão perguntada aos alunos foi com relação ao aprendizado, tendo como referência as demais disciplinas do semestre. A finalidade foi saber como eles avaliavam seu aprendizado em relação às demais disciplinas do semestre. Neste caso ficou claro que a grande maioria considerou ter um aprendizado melhor ou semelhante ao de qualquer outra disciplina presencial do curso naquele semestre, conforme a Figura 4.7. Também se observa que, ao longo dos anos, o percentual que avaliou o aprendizado como melhor do que o esperado aumentou progressivamente. No ano de 2013 apresentou o maior valor, igual ao percentual daqueles que consideraram semelhante ao esperado para outras disciplinas (Figura 4.7). 


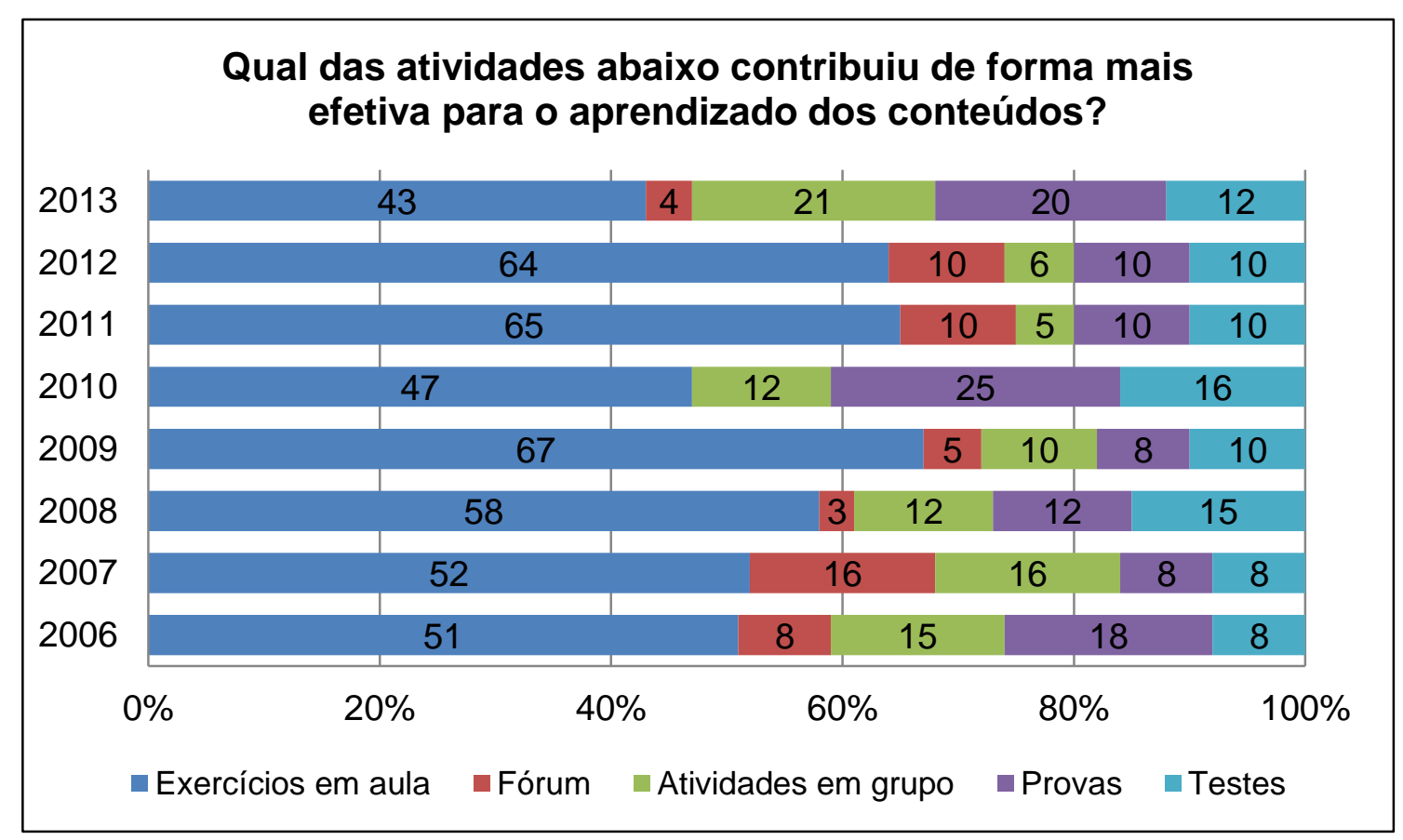

Figura 4.6: Atividades que mais contribuíram para o aprendizado

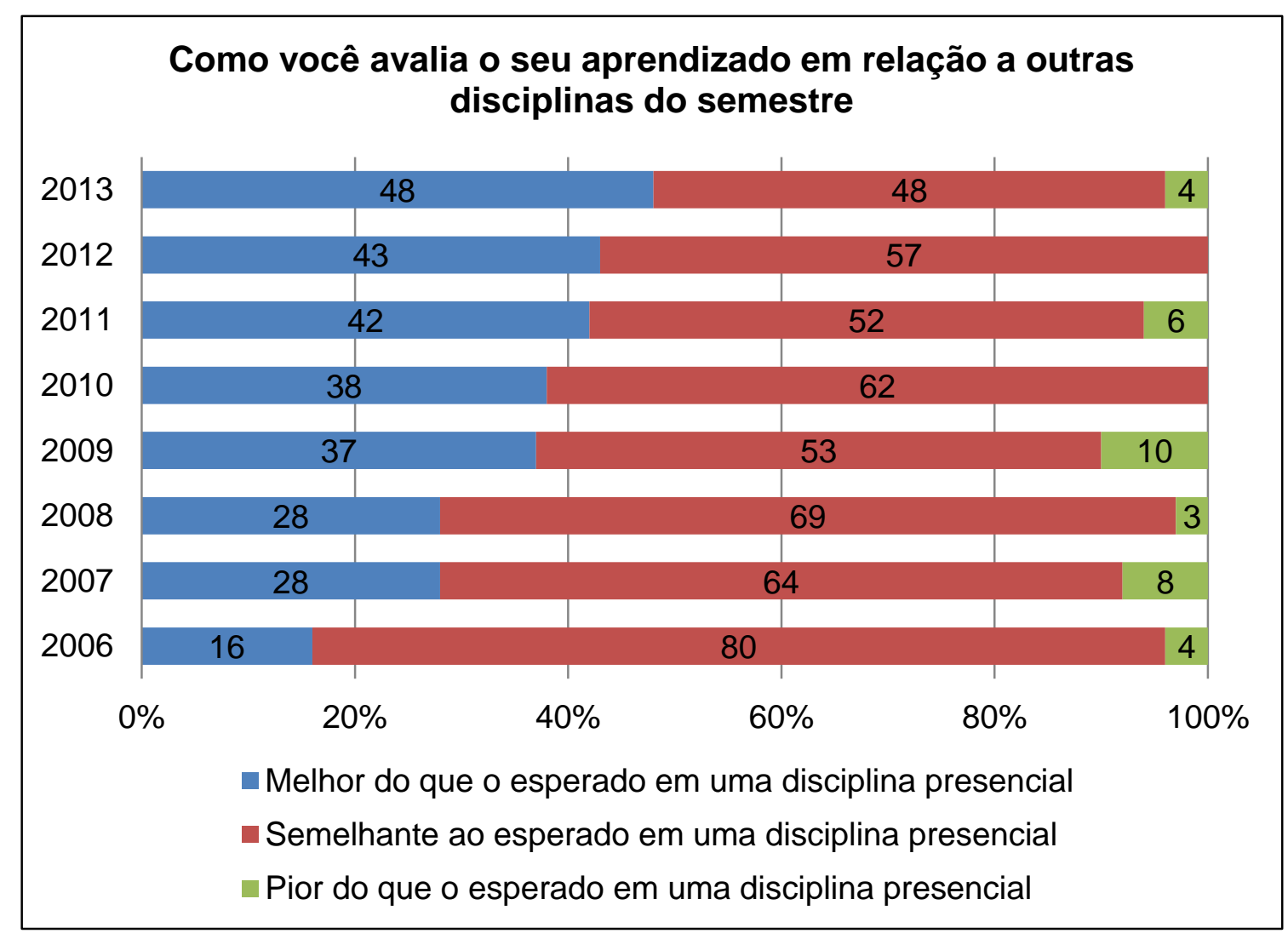

Figura 4.7: Avaliação do aprendizado em relação à outras disciplinas do curso

A avaliação global foi positiva e refletiu bem o emprego dos procedimentos adotados na disciplina ao longo dos anos de 2006 a 2013. Na Figura 4.8, tem-se que a grande maioria dos alunos considerou a disciplina como muito boa a boa ao longo desses anos. Destaca-se 
que no ano de 2013 nenhum aluno considerou a disciplina "abaixo" de bom. Desta forma, estes valores percentuais podem dar indicativo da aceitação, por parte dos alunos, da forma geral como a disciplina foi conduzida nestes anos letivos. Destaca-se também que a dedicação do docente e dos monitores do programa PAE nestes anos também deve ser considerada para a boa aceitação da disciplina.

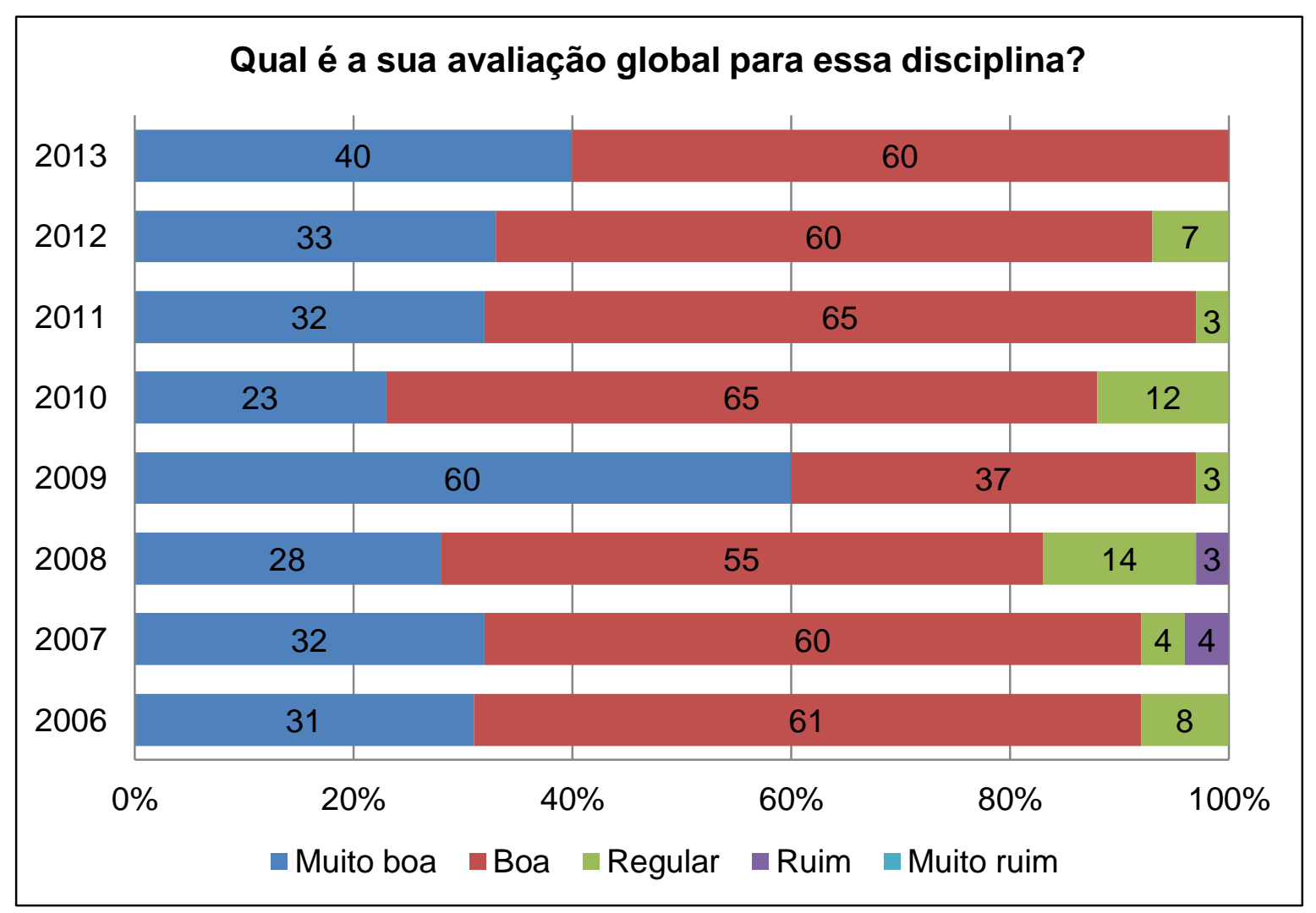

Figura 4.8: Avaliação global dos alunos em relação à disciplina

O formato definido para a disciplina considerada nesta pesquisa basicamente envolveu: aulas expositivas; uma atividade de aprendizagem na forma de resolução de problema e o uso de uma plataforma online para auxiliar todas as atividades de ensino-aprendizagem.

Após a experiência de cursar a disciplina, era preciso saber se os alunos fariam outra disciplina que tivesse este mesmo arranjo de ensino-aprendizagem. Desta forma, na Figura 4.9 observa-se que a grande maioria dos alunos voltaria a cursar uma disciplina neste formato. Pode-se destacar, no ano de 2013, o maior percentual de alunos que voltariam a cursar outra disciplina similar àquela desenvolvida naquele ano. 
Ainda considerando o ano de 2013, destacam-se comentários feitos pelos alunos que podem indicar que o formato da disciplina foi considerado adequado. Na Tabela 4.4 são apresentados alguns comentários que podem corroborar os dados da Figura 4.9.

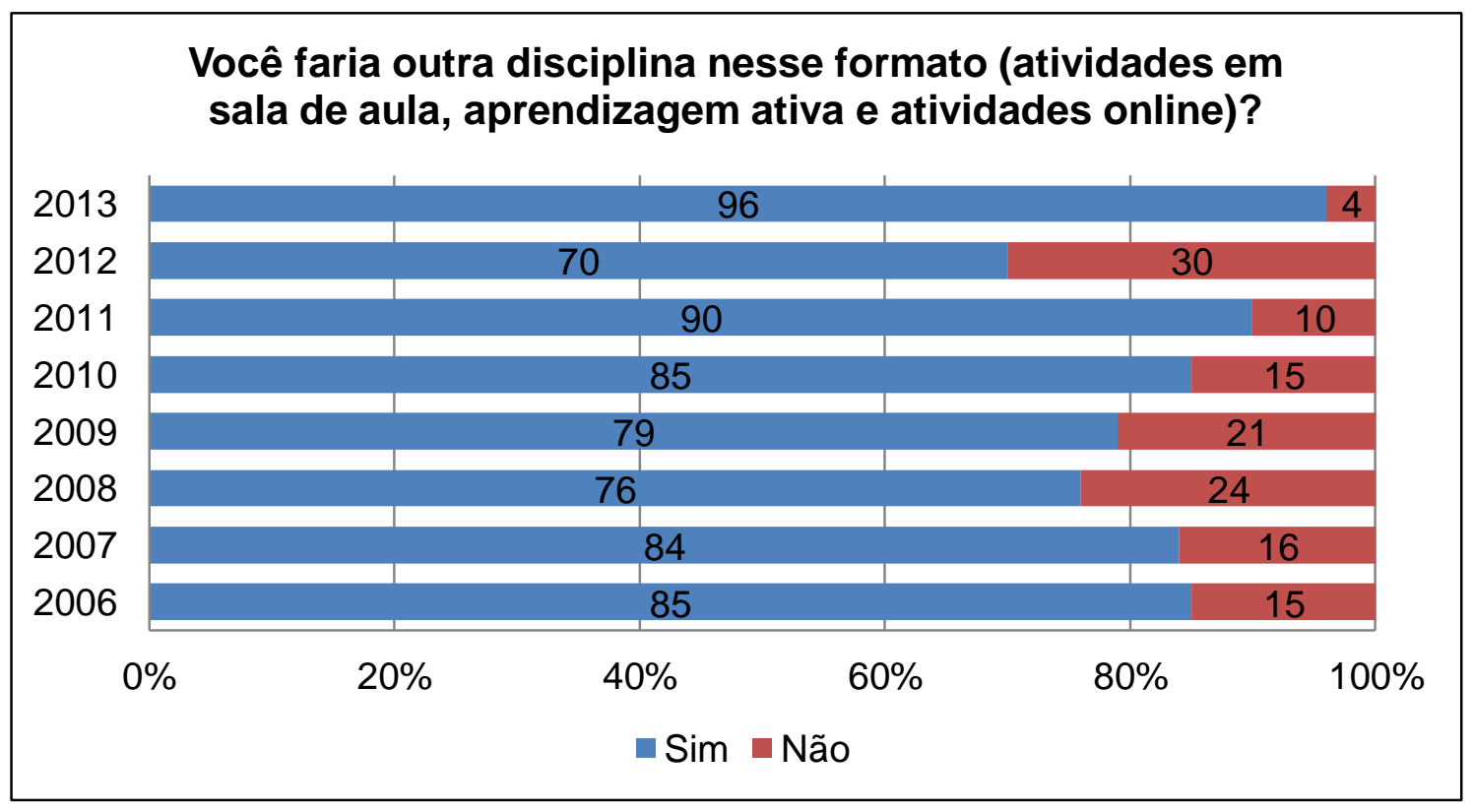

Figura 4.9: Opinião dos alunos sobre a possibilidade de fazer outra disciplina neste formato

Tabela 4.4: Comentários de alunos da Turma 2 - 2013 sobre o formato da disciplina.

\footnotetext{
Aluno Comentário da questão: "você faria outra disciplina nesse formato (atividades em sala de aula, aprendizagem ativa e atividades online)?".

MYM

"Sim, desde que o docente fosse dedicado e soubesse expor de modo adequado suas atividades, assim como ocorreu nessa disciplina."

AF "Sim, as atividades extraclasses são fundamentais para aliar a teoria à prática."

DS "Sim, justamente por fornecer bastante material e bastante exemplos para o futuro."

A proposta básica da disciplina foi mesclar aulas expositivas e uma atividade de projeto na forma de resolução de problemas. Além disso, havia uma plataforma online que foi usada para suporte e gerenciamento de diversos procedimentos. A finalidade de fazer esta combinação foi dar aos alunos autonomia para atingir os objetivos educacionais projetados pela taxonomia dos objetivos educacionais usada nesta pesquisa.
} 
Desta forma, com base nos resultados apresentados na Figura 4.10, observa-se que a maioria dos alunos, em todos os anos analisados, considerou a proposta da disciplina entre adequada e muito boa. Ainda que existissem percentuais de alunos que consideraram a proposta regular a ruim, pode-se concluir, com base nas respostas obtidas, que a combinação de aulas expositivas e aprendizagem ativa é viável e representa uma alternativa que pode ser desenvolvida em cursos regulares de engenharia.

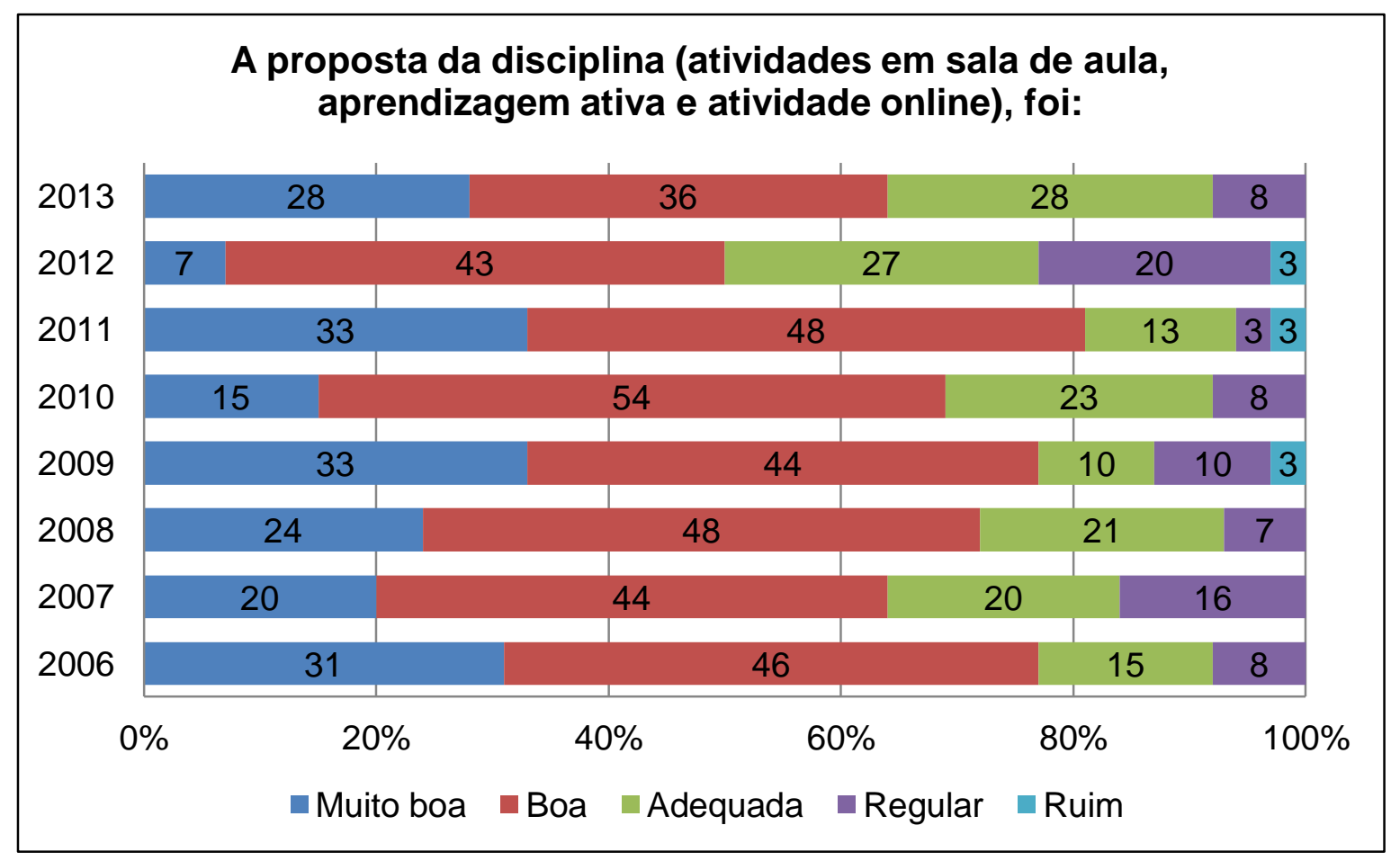

Figura 4.10: Avaliação dos alunos em relação à proposta da disciplina

A questão da medida do aproveitamento de alunos em disciplinas pode gerar uma série de debates e considerações sobre a melhor maneira de conduzir este processo. A maneira adotada neste trabalho para obter esta informação foi por meio da própria percepção dos alunos em relação aos seus aproveitamentos. Desta forma, os alunos foram perguntados como eles classificariam seu aproveitamento na disciplina. Conforme a Figura 4.11, a grande maioria dos alunos considerou seu aproveitamento entre bom e excelente. Isso pode ser um indicativo de que a maioria sentiu-se a vontade em relação às atividades desenvolvidas. Pode indicar, ainda com segurança, sua percepção sobre uma questão controversa, que é o aproveitamento em atividades de ensino-aprendizagem. Vale ressaltar que o aproveitamento aqui considerado refere-se aos valores de notas obtidos em provas, testes e desenvolvimento do projeto na forma de resolução de problemas. 


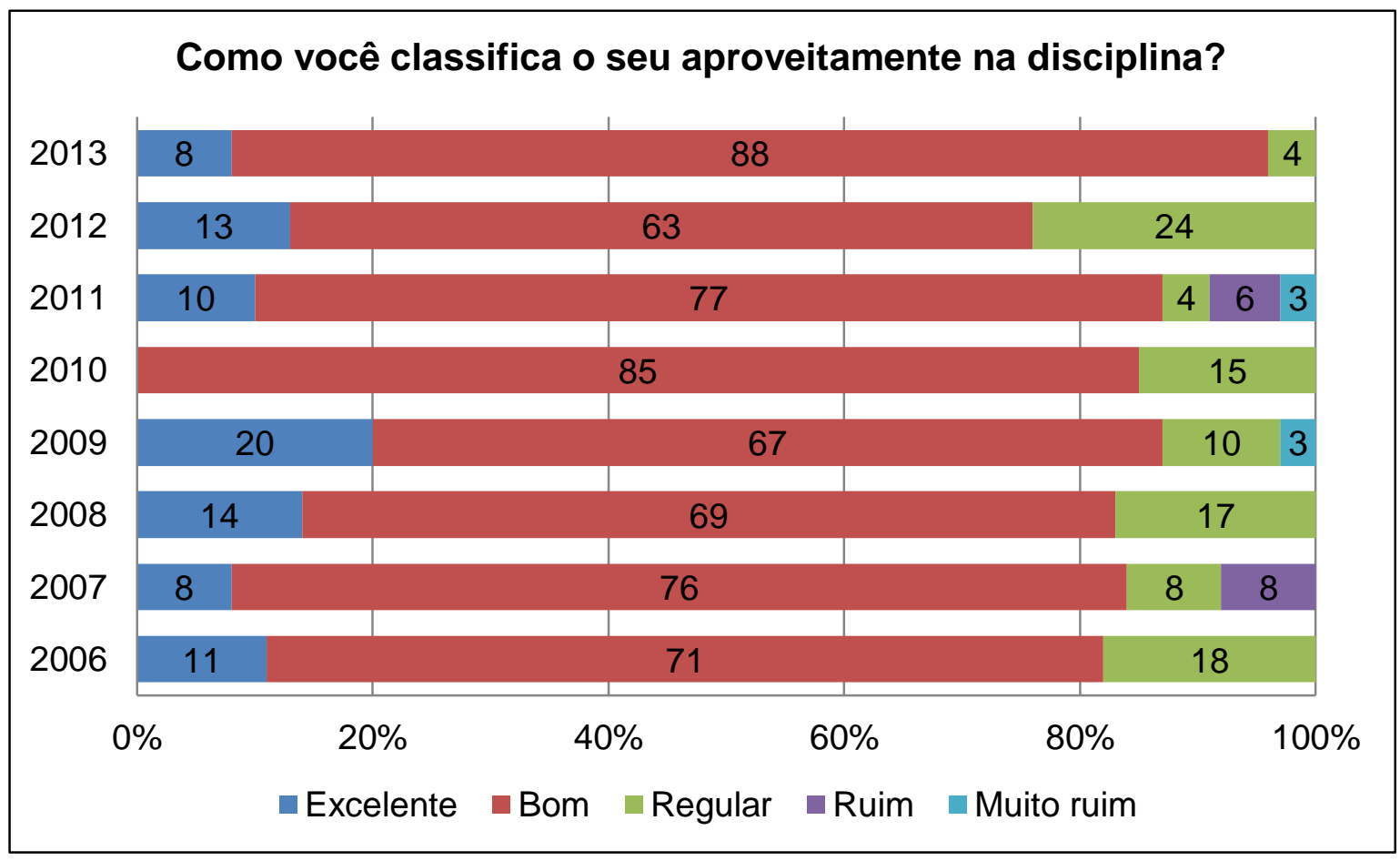

Figura 4.11: Percepção dos alunos a respeito dos seus próprios desempenhos na disciplina

No Brasil, atualmente, a maior parte dos projetos pedagógicos de cursos de engenharia pode ser classificado como tradicional. Estes cursos possuem uma matriz curricular com disciplinas distribuídas semestralmente e/ou anualmente e que na maioria das vezes não possuem integração de conteúdos. Desta forma, adotar métodos ou formatos diferenciados pode causar protestos de todos os atores envolvidos no processo de ensino-aprendizagem. Sendo assim, foi solicitada a percepção dos alunos sobre o tempo dedicado às atividades da disciplina de Planejamento e Análise de Sistemas de Transportes.

$\mathrm{Na}$ Figura 4.12 observa-se um relativo equilíbrio entre as respostas daqueles que concordam e daqueles que discordam que as tarefas da disciplina tomaram mais tempo do que as tarefas de outras disciplinas. $O$ fato de uma disciplina em um formato diferenciado ser desenvolvida em conjunto com outras disciplinas tradicionais pode gerar, em alunos e professores, a expectativa de que as disciplinas que usam a abordagem diferenciada necessitem maior tempo para o desenvolvimento de suas atividades de ensinoaprendizagem.

Em função das dificuldades apresentadas percebe-se que muitos alunos possuem dificuldades em administrar o tempo para desenvolver as diversas atividades de um curso de engenharia. Esta dificuldade é muitas vezes utilizada como argumento para demover 
professores a não utilizarem métodos de aprendizagem ativa em conjunto com aulas tradicionais.

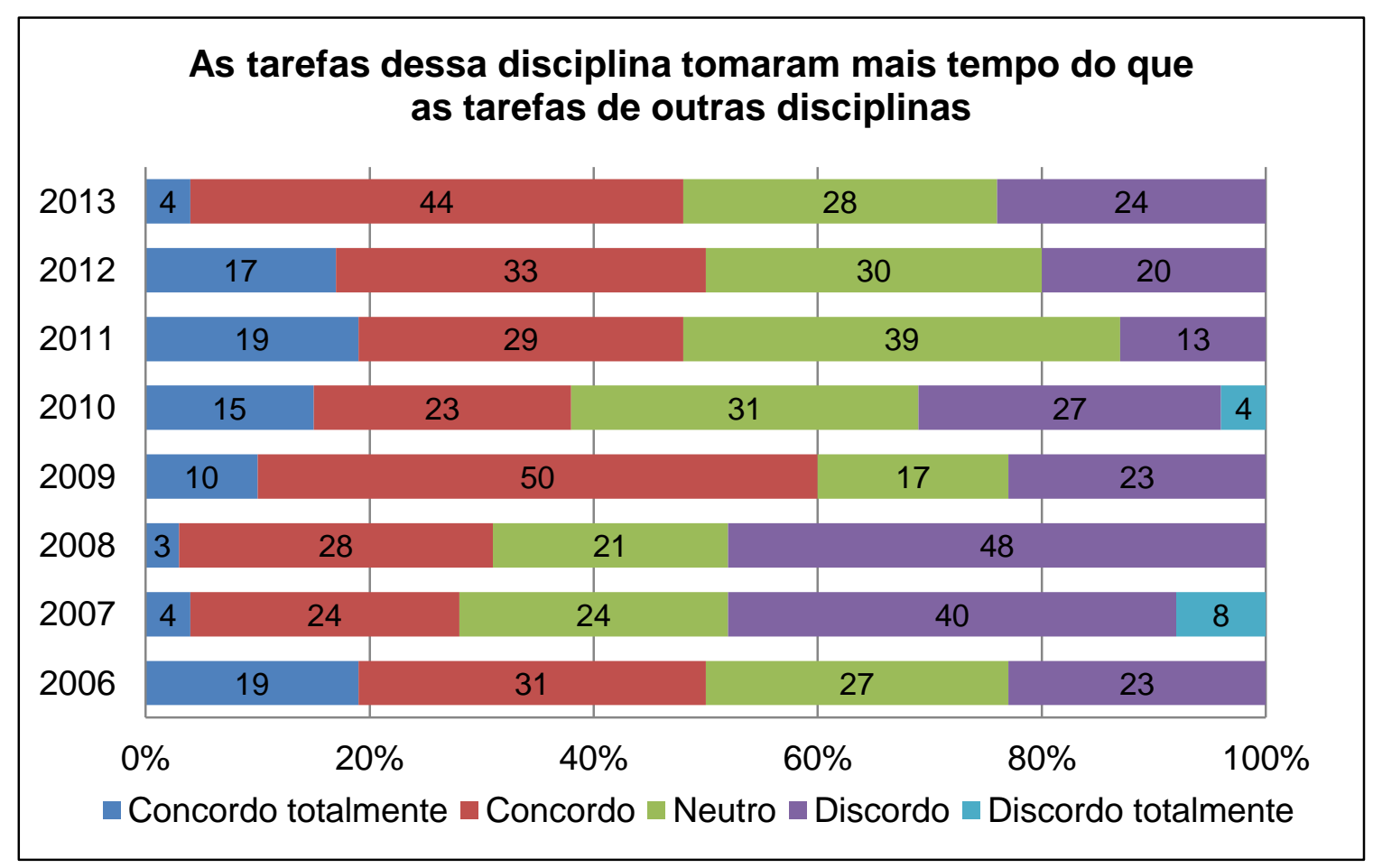

Figura 4.12: Percepção dos alunos em relação ao tempo dedicado à disciplina

Para corroborar os percentuais apresentados na Figura 4.12, na Tabela 4.5 são apresentados comentários feitos por dois alunos e que se referem ao tempo dedicado as tarefas da disciplina de Planejamento e Análise de Sistemas de Transportes. Segundo os alunos, a disciplina teve um nível de exigência "maior que as de uma disciplina convencional”. Este nível de exigência traduziu-se principalmente em questões de tempo.

Tabela 4.5: Comentários de alunos da Turma 2 - 2013 sobre o tempo dedicado às tarefas da disciplina de Planejamento e Análise de Sistemas de Transportes.

Aluno

Comentário

TB "Diria que solicitou mais encontros e maior discussão"

IZ

"Maior que a maioria das disciplinas convencionais, mas semelhante a outras disciplinas ofertadas pelo departamento de transportes"

As plataformas online Col e TIDIA-Ae foram usadas como ferramenta de suporte em diversas etapas da disciplina e desta pesquisa. A partir do ano de 2012 o sistema Col foi 
substituído pelo TIDIA-Ae no gerenciamento das atividades. Desta forma, era preciso saber qual a percepção dos alunos em relação a este tipo de plataforma de suporte online.

$\mathrm{Na}$ Figura 4.13 tem-se a quantidade de vezes que os alunos acessaram os sistemas Col ou TIDIA-Ae antes de cursarem a disciplina de Planejamento e Análise de Sistemas de Transportes. Os resultados indicam que a grande maioria dos alunos não tinha tido contato regular com estas plataformas online. Ressalta-se que no ano de 2011 todos os alunos indicaram que nunca tinham usado nenhuma das plataformas antes.

Porém, mesmo com o pouco contato dos alunos, conforme os valores percentuais apresentados na Figura 4.13, pode-se dizer que não houve dificuldades em relação ao uso das plataformas Col ou TIDIA-Ae usadas nesta pesquisa. Isto também pode ser corroborado pelos resultados apresentados na Figura 4.14, onde se observa que a maioria dos alunos considerou o uso dos sistemas online como regular a muito bom.

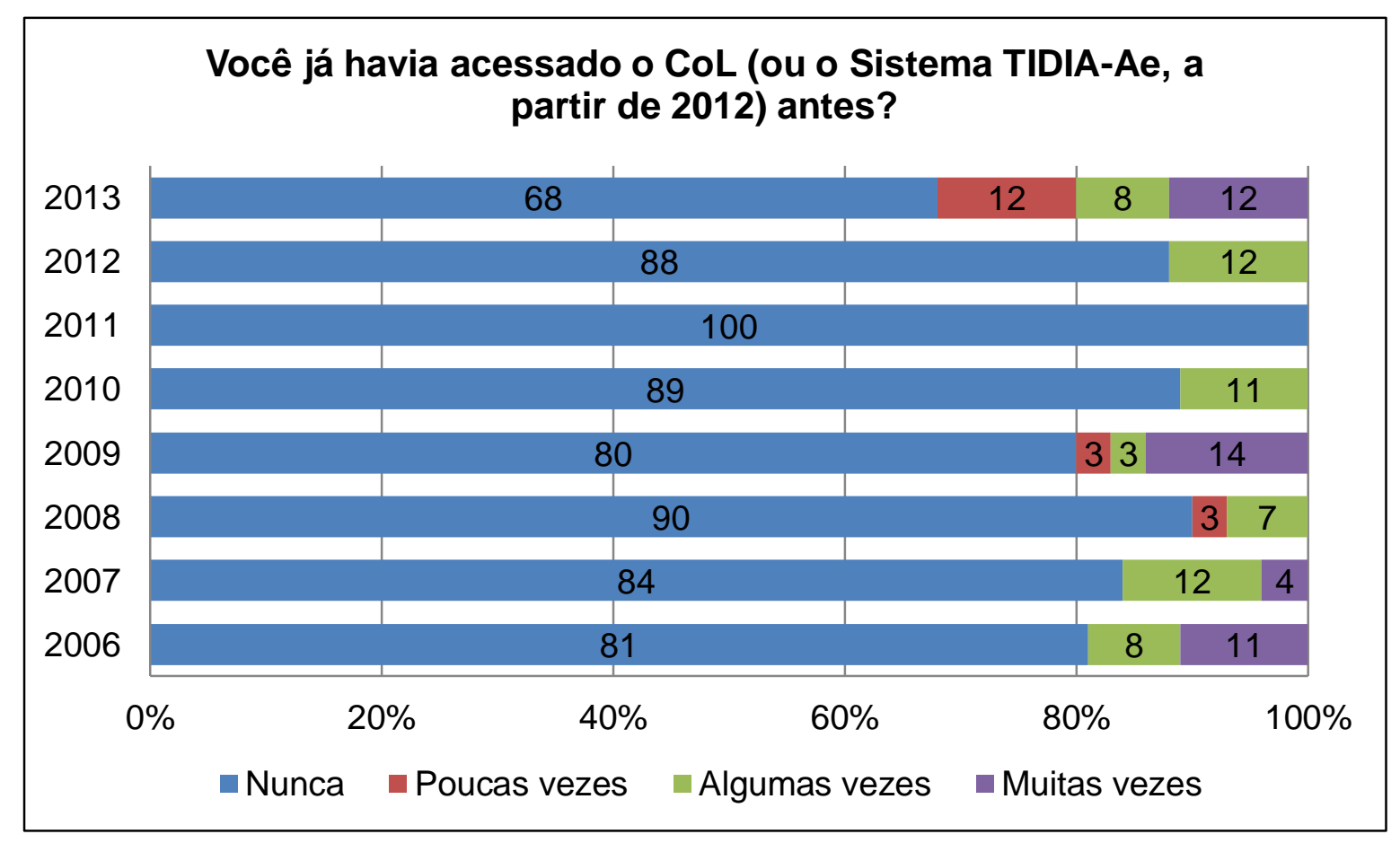

Figura 4.13: Contato dos alunos com sistema Col ou TIDIA-Ae

Ainda com relação aos ambientes de suporte online, na Tabela 4.6 são apresentados comentários feitos por dois alunos no questionário online. Estes comentários ajudam a entender melhor os resultados apresentados na Figura 4.13 e 4.14. Além disso, reforçam a necessidade de aproveitar as ferramentas disponíveis para melhorar o processo de ensinoaprendizagem. A principal questão apontada pelos alunos é que essas plataformas estão 
subutilizadas e, caso passassem a ser utilizadas de forma mais regular, poderiam contribuir para aperfeiçoar as diversas atividades desenvolvidas nas disciplinas em geral.

Tabela 4.6: Comentários de alunos da Turma 2 - 2013 sobre o TIDIA-Ae

\begin{tabular}{cl}
\hline Aluno & Comentário \\
\hline JB & $\begin{array}{l}\text { "Único problema é que é utilizada por poucos professores. Seria muito melhor se todas as } \\
\text { disciplinas estivessem concentradas no Tidia-Ae." }\end{array}$ \\
& "Vendo como atualmente os professores da USP ensinam em sala de aula e fornecem os \\
DS $\quad \begin{array}{l}\text { seus materiais, o Tidia-Ae é excelente, simplesmente por disponibilizar tais materiais, que } \\
\text { a maioria tem dificuldades para fornecer, e também pela possibilidade que o TIDIA tem de } \\
\text { gerar discussão em um fórum." }\end{array}$
\end{tabular}

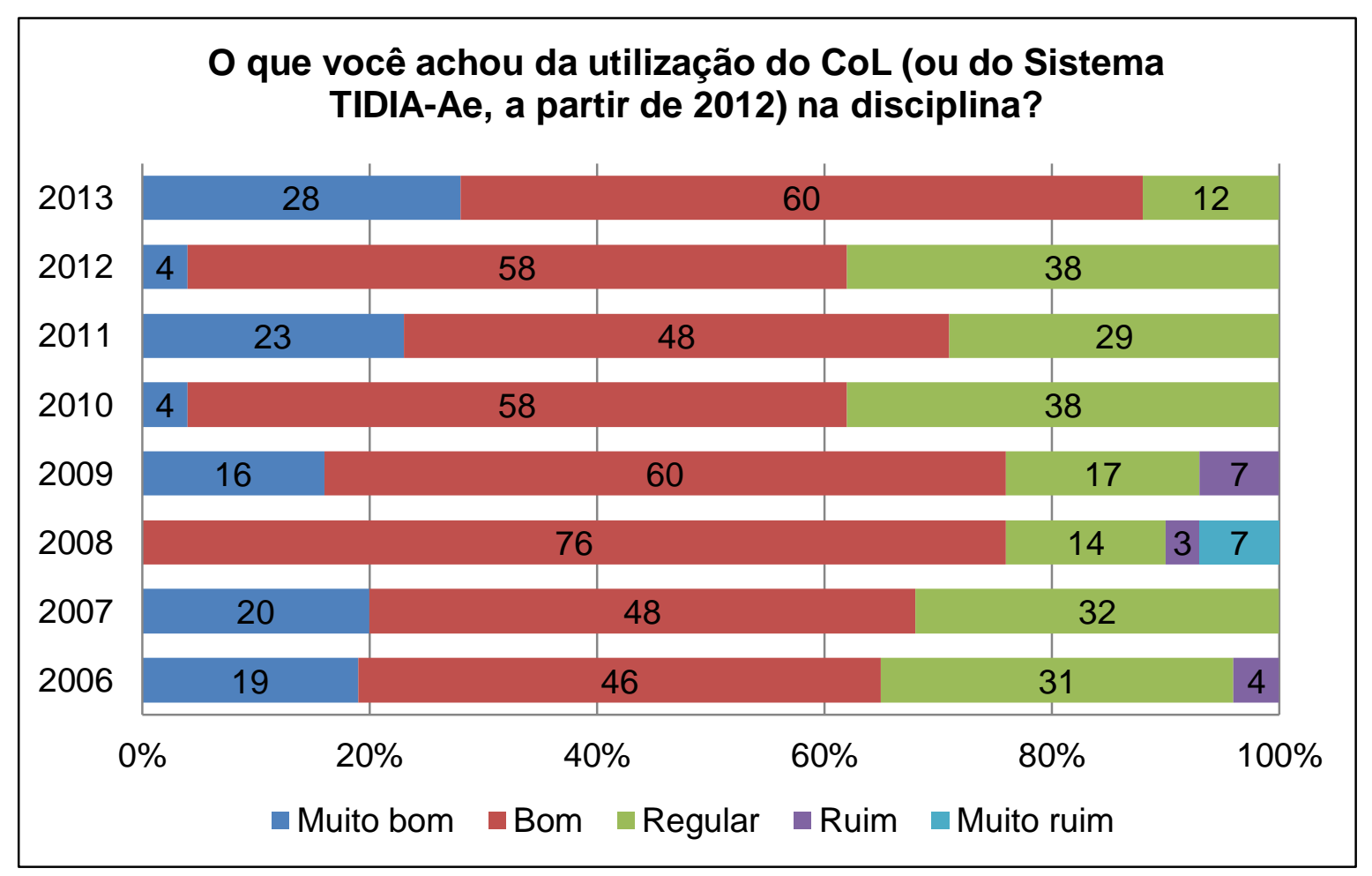

Figura 4.14: Percepção dos alunos em relação as plataformas online

Com relação ao nível de exigência das atividades online da disciplina de Planejamento e Análise de Sistemas de Transportes em relação às atividades de outras disciplinas, na Figura 4.15 observa-se que a grande maioria achou maior ou igual ao nível de exigência de outras disciplinas. A quantidade de alunos que achou menor foi relativamente baixa, com exceção para o ano de 2008. O fato de uma boa parcela dos alunos ter considerado o nível de exigência das atividades relativamente maior do que em uma disciplina convencional 
pode ser um indicativo da falta de contato com as plataformas online. Além disso, é preciso considerar que é necessário se habituar a manusear a plataforma e gerenciar seus recursos e este aspecto pode gerar a percepção de maior nível de exigência.

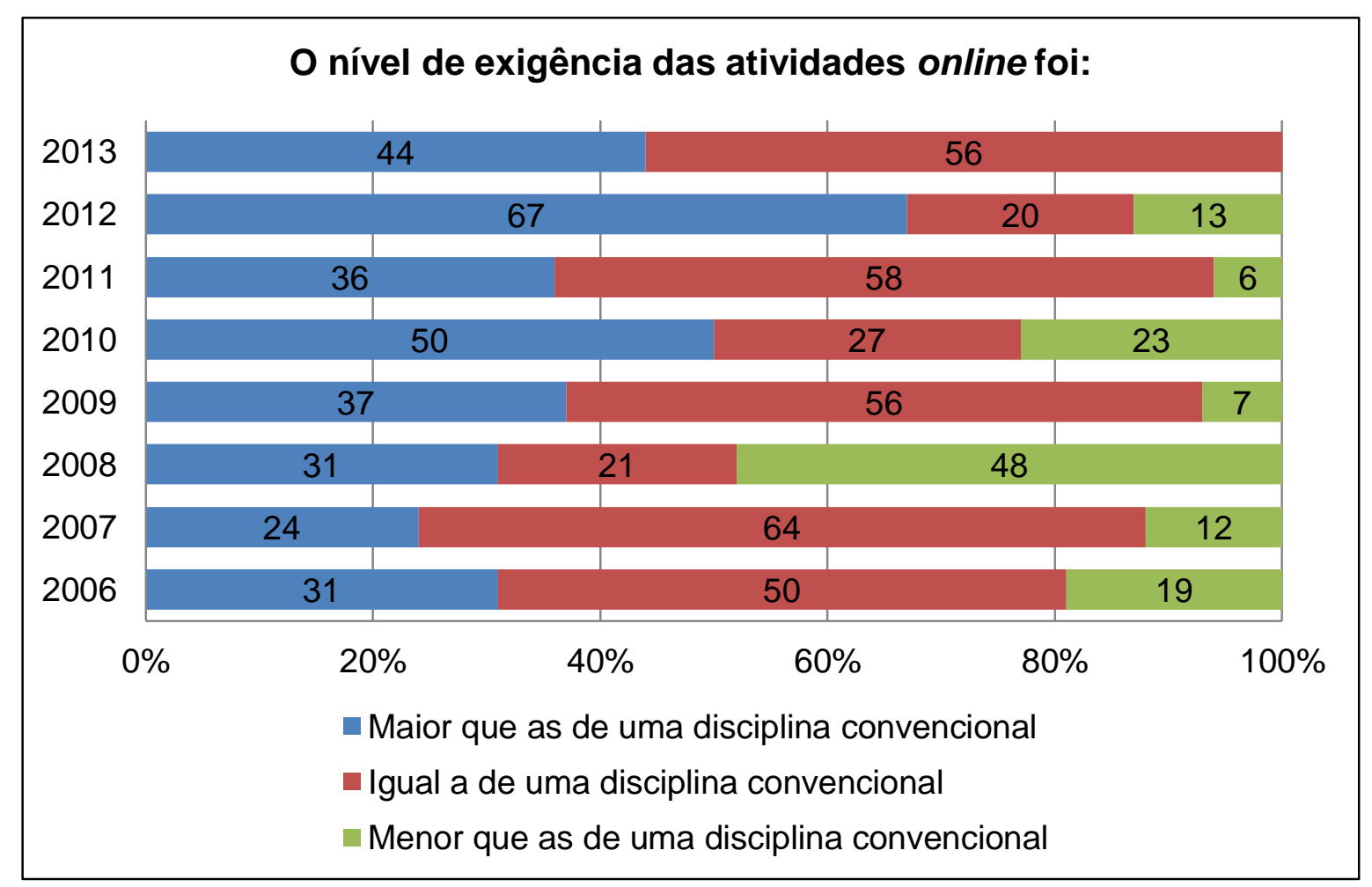

Figura 4.15: Percepção dos alunos em relação ao nível de exigência das atividades online

Ainda com relação aos sistemas Col e TIDIA-Ae, tem-se na Figura 4.16 a preferência dos alunos em relação ao meio de interação para desenvolver as atividades da disciplina. Observa-se que a atividade em grupo consolidou-se como o meio preferido pelos alunos. Destaca-se que no ano de 2013 , tem-se o maior percentual de preferência para a atividade em grupo. Isto reforça que o formato da disciplina tem conseguido atender às preferências de aprendizagem dos alunos ao usar atividades de aprendizagem ativa.

Na Tabela 4.7 são apresentados alguns comentários relativos ao meio de interação favorito dos alunos. Os comentários referem-se a pergunta: Qual dos meios de interação providos foi o seu favorito? A resposta destes três alunos para esta pergunta foi: Atividade em grupo. 


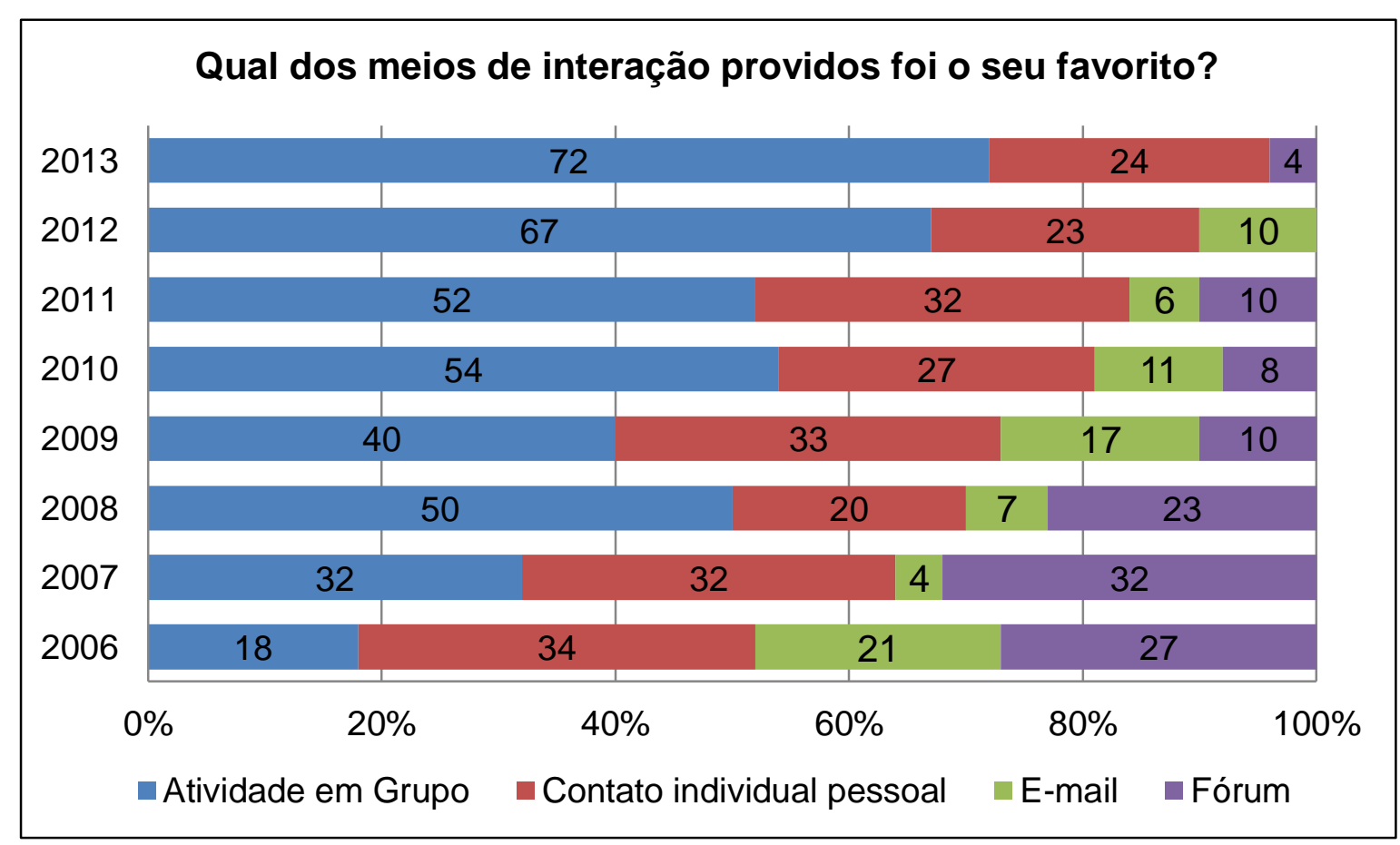

Figura 4.16: Meios de interação favoritos disponibilizado na disciplina

Tabela 4.7: Comentários de alunos da Turma 2 - 2013 sobre o meio de interação favorito nas atividades da disciplina.

\begin{tabular}{|c|c|}
\hline Aluno & Comentário \\
\hline $\mathrm{JB}$ & $\begin{array}{l}\text { "Acho que para algumas discussões reuniões presenciais rendem mais que fóruns ou } \\
\text { conversar online (e-mail, facebook)." }\end{array}$ \\
\hline DS & $\begin{array}{l}\text { "Material fornecido pelo TIDIA-Ae, além do modo como foi feita as aulas com bastante } \\
\text { interação com turma." }\end{array}$ \\
\hline IZ & $\begin{array}{l}\text { "Apesar de ter sido difícil, num primeiro instante, ter uma interação entre todos os } \\
\text { integrantes, achei muito interessante ter pessoas com perfis diferentes para quebrar as } \\
\text { "panelinhas" e desenvolver a habilidade de lidar com pessoas diferentes de nós (situação } \\
\text { que encontraremos no ambiente de trabalho)." }\end{array}$ \\
\hline
\end{tabular}

Nas Figuras 4.17 a 4.20 têm-se os resultados relativos à atividade de aprendizagem ativa que foi usada em conjunto com as aulas expositivas na disciplina de Planejamento e Análise de Sistemas de Transportes. Esta atividade foi aplicada conforme a metodologia da problematização ou resolução de problemas, definida por Berbel (1998).

Com relação ao desempenho na atividade de aprendizagem ativa, observa-se na Figura 4.17 que em praticamente todos os anos letivos os alunos indicaram que tiveram 
desempenho bom a excelente. A única exceção seria para o ano de 2009, onde houve um ligeiro equilíbrio nas respostas. Também no ano de 2010 houve um pequeno percentual de alunos que indicou que seus desempenhos foram muito ruins. De um modo geral, os resultados evidenciam que o nível de participação dos alunos na atividade de aprendizagem ativa gerou bons aproveitamentos. Isto se refletiu em um bom desempenho nas atividades e soluções apresentadas pelos grupos.

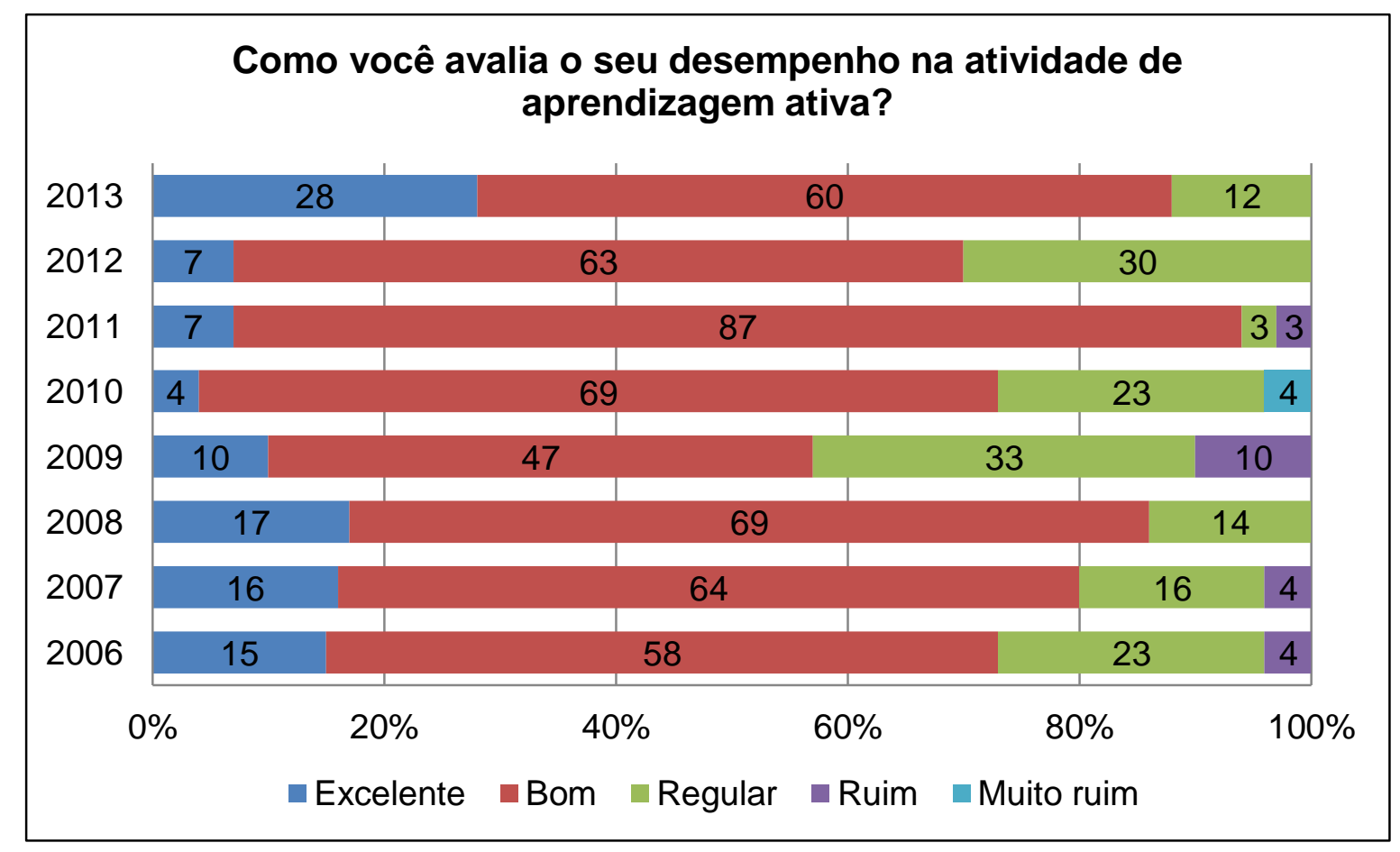

Figura 4.17: Percepção dos alunos a respeito dos seus desempenhos na atividade de aprendizagem ativa

Uma das preocupações em relação às atividades realizadas em grupo é o nível de interação entre seus membros. Desta forma, os alunos foram perguntados como se sentiam nas tarefas realizadas em equipe. Alguns alunos muitas vezes sentem dificuldades para interagir em grupo. Uma pequena parcela quase nunca se sentiu a vontade nas atividades de grupo, conforme a Figura 4.18. Também se pode observar que houve uma parcela razoável que às vezes se sentiu à vontade.

As atividades que geram formas de interação entre os alunos durante um curso de graduação em engenharia podem ser benéficas e motivadoras. Além disso, podem auxiliálos a vencer barreiras ou receios em relação ao ambiente profissional no atual contexto da engenharia. Diversos estudos demonstram que a engenharia basicamente é desenvolvida por equipes de trabalho. Saber conviver com essas situações pode ser, portanto, promissor na carreira de um engenheiro. 
Uma das preocupações desta pesquisa foi reproduzir, no trabalho de equipe, o ambiente profissional da engenharia, em que pessoas de diferentes estilos de aprendizagem e perfis de personalidade atuam na resolução de um problema. Desta forma, os alunos teriam a oportunidade de conviver com experiências concretas e que podem acontecer no futuro profissional.

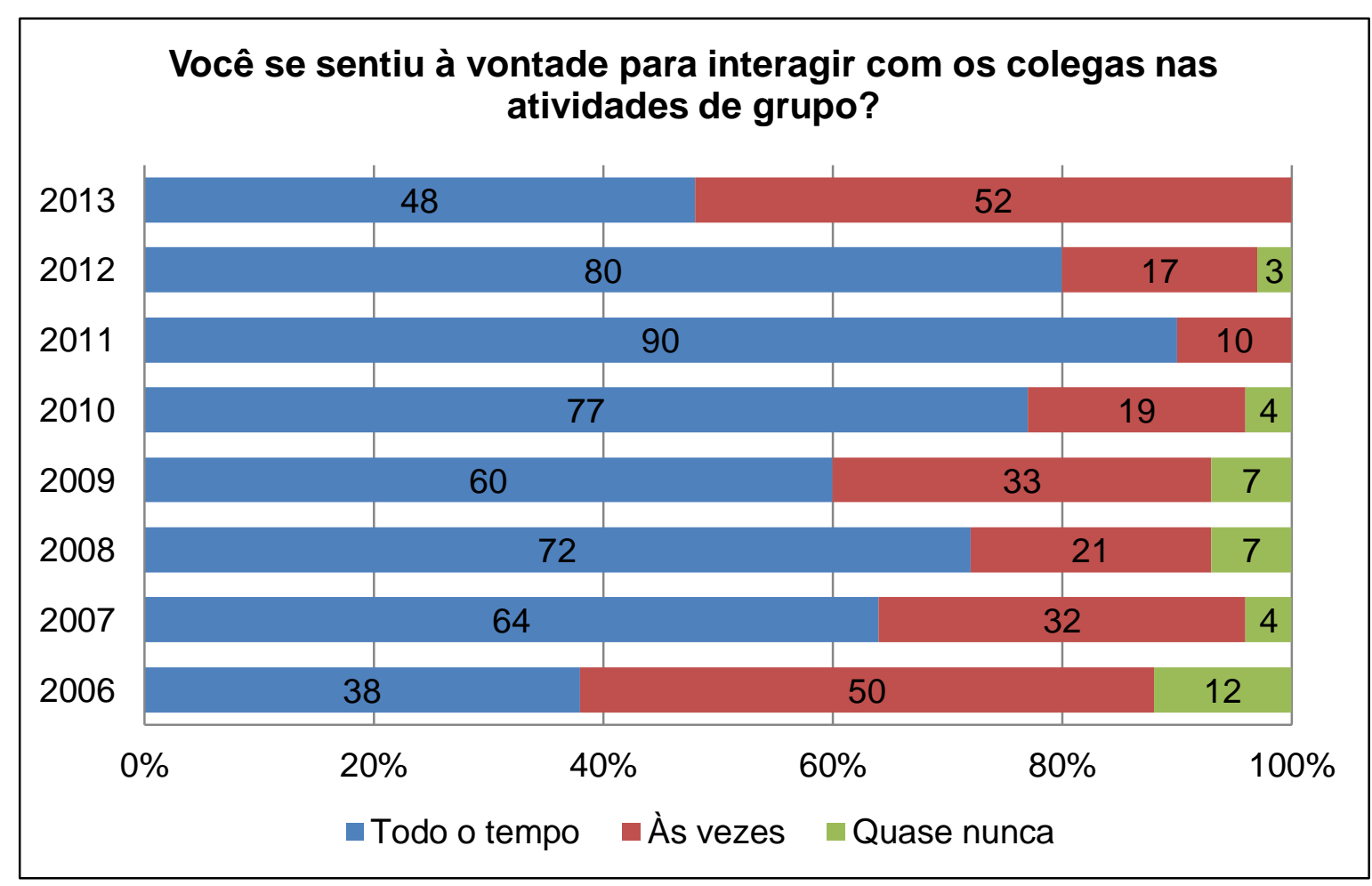

Figura 4.18: Percepção dos alunos sobre o nível de interação nas atividades em grupo

Com relação à atividade de aprendizagem ativa, a maioria dos alunos considerou a atividade boa a excelente, conforme a Figura 4.19. Isto pode ser uma evidência da aceitação e adequação deste tipo de método de ensino-aprendizagem em disciplinas de cursos de engenharia.

$\mathrm{Na}$ Tabela 4.8 são apresentados comentários dos alunos sobre a atividade de aprendizagem ativa. Observa-se que a principal preocupação dos alunos é com relação ao tempo necessário ou disponível para a execução das atividades. Por outro lado eles também perceberam que a atividade foi importante por ter uma abordagem relativamente diferente da convencional. 


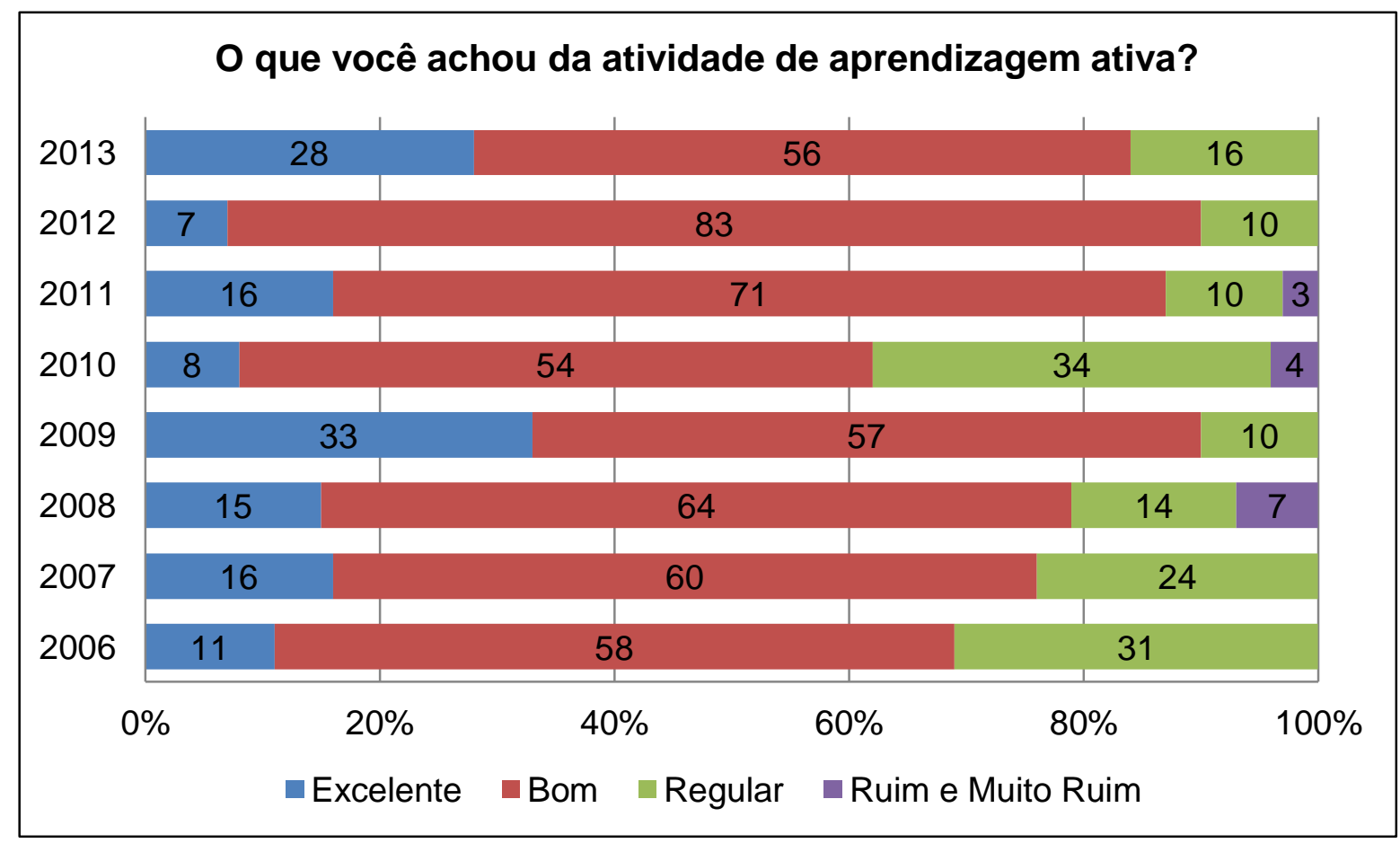

Figura 4.19: Percepção dos alunos em relação às atividades de aprendizagem ativa

Tabela 4.8: Comentários de alunos da Turma 2 - 2013 sobre a atividade de aprendizagem ativa.

Aluno Comentário

SN "Excelente, pois foi realizado através de uma abordagem diferente da convencional."

TL "Ficou muito corrido realizar o projeto."

TB

"Disciplinas com projetos sempre ocupam mais tempo, mas vale pela "chance" a mais de melhorar a nota."

"Tinha receio de o trabalho em grupo tomar muito tempo, mas como era possível fazer

IZ reuniões apenas para discutir os assuntos e depois dividir as tarefas, deu para administrar bem o tempo livre."

Uma questão que pode motivar os alunos a trabalharem ou desenvolverem atividades em uma disciplina que aplica conceitos de aprendizagem ativa é a possibilidade de autonomia e desenvolvimento do senso crítico. Ao tentar fazer com que os alunos atingissem níveis elevados de cognição, conforme os objetivos educacionais planejados inicialmente, o professor espera estimular a capacidade de tomada de decisão e a formação do espírito crítico. Na Figura 4.20, pode-se observar que a maioria dos alunos concordou que 0 
professor, ao formatar as atividades da disciplina, conforme elas foram desenvolvidas, estimulou a formação do espírito crítico. Este quesito pode corroborar a eficácia da aplicação de métodos ativos de ensino-aprendizagem em conjunto com procedimentos de aulas expositivas tradicionais.

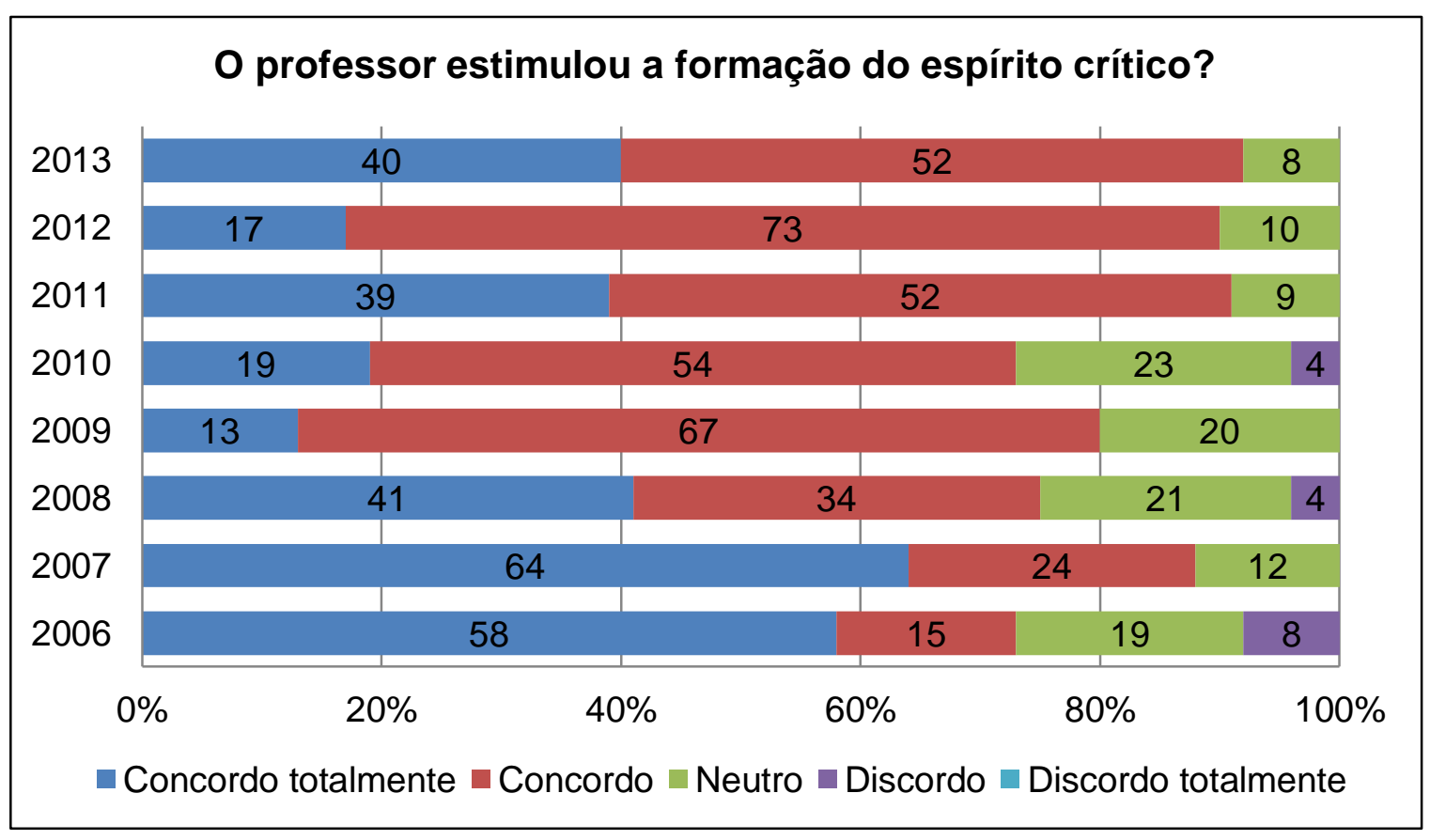

Figura 4.20: Percepção dos alunos sobre a formação do espírito crítico nas atividades desenvolvidas

De um modo geral os dados apresentados nas Figuras 4.5 a 4.20 corroboram a aceitação, por parte dos alunos, da forma geral como a disciplina foi conduzida entre os anos letivos de 2006 a 2013. Com base nos dados apresentados podem ser feitas as seguintes afirmações:

- A disciplina de Planejamento e Análise de Sistemas de Transportes apresentou uma boa avaliação global;

- A proposta da disciplina que combinou aulas expositivas, aprendizagem ativa e atividades online foi bem aceita pela maioria dos alunos;

- Os sistemas online de aprendizagem (Col e TIDIA-Ae) foram bem avaliados pelos alunos, mas poderiam ser mais usados pelos docentes da instituição, no caso específico desta pesquisa;

- A atividade de aprendizagem ativa foi bem aceita pelos alunos e considerada adequada para ser usada em conjunto com aulas expositivas. 


\subsubsection{Análise da percepção da Turma de 2012 e Turma 2 de 2013 em relação a disciplina e suas abordagens}

Esta abordagem será feita principalmente em relação àqueles itens em que houve diferenças na percepção das duas turmas avaliadas especificamente neste estudo, ou seja, a Turma de 2012 e a Turma 2 de 2013. Neste caso, ao se referir a Turma 2 de 2013 nas análises deste item será feita menção apenas a Turma de 2013. O objetivo desta análise é apresentar itens sobre a percepção dos estudantes que possam ser melhor explicados e que sirvam de base para aperfeiçoamentos futuros dos procedimentos adotados em disciplinas que procurem mesclar aulas expositivas tradicionais, aprendizagem ativa e ambiente colaborativo online. A comparação dos resultados seguirá os seguintes temas: i) avaliação geral da disciplina pelos alunos; ii) percepção dos alunos em relação ao formato da disciplina; e iii) opinião dos alunos em relação ao ambiente online Tidia-Ae.

Houve uma ligeira diferença na avaliação geral da disciplina por parte das duas turmas que foram consideradas nesta análise. Conforme a Figura 4.21, a Turma de 2013 foi muito mais receptiva ao conteúdo da disciplina do que a Turma de 2012. A receptividade desta turma pode estar relacionada à familiaridade com o tema da disciplina, pois alguns alunos revelaram já ter cursado disciplinas optativas relacionadas à área de engenharia de transportes.

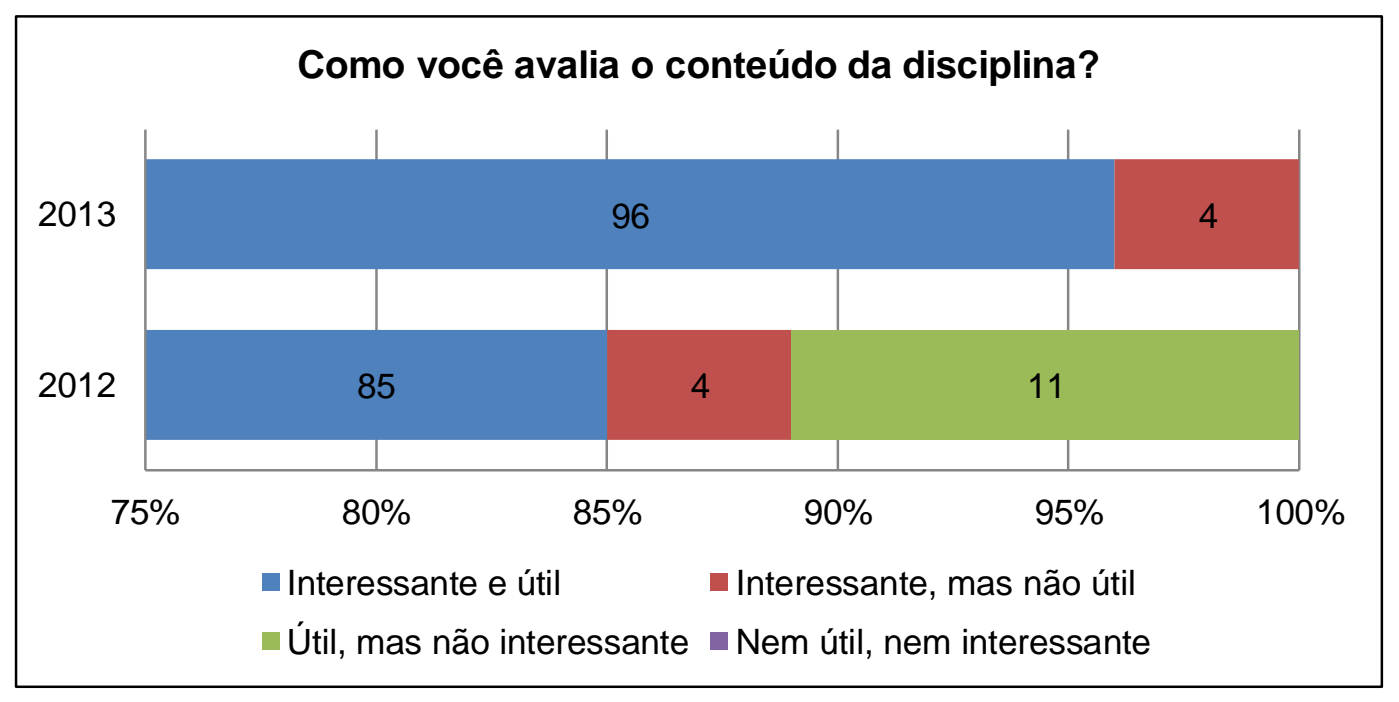

Figura 4.21: Diferenças na avaliação do conteúdo

Já com relação aos procedimentos conduzidos durante a disciplina, na Figura 4.22, tem-se as seguintes questões: $l$ ) exercícios em aula, na percepção dos alunos da Turma de 2013, não contribuíram tanto para o aprendizado dos conteúdos quanto consideraram os alunos 
da Turma de 2012; ii) segundo a percepção dos alunos das duas turmas, o fórum continua sendo a atividade que menos contribui para o aprendizado dos conteúdos da disciplina, apesar de que na Turma 2013 o percentual caiu pela metade em relação a Turma de 2012; ii) as Atividades em Grupo, passaram a ser mais consideradas pelos alunos nas suas opiniões na Turma de 2013 em relação a Turma de 2012. Isto pode sugerir que a atividade de aprendizagem ativa (metodologia da problematização) teve uma melhor aceitação por parte dos alunos da Turma de 2013 como ferramenta ou método de ensino-aprendizagem; e iv) as demais atividades, provas e testes, mantiveram seus valores percentuais alinhados nas duas turmas.

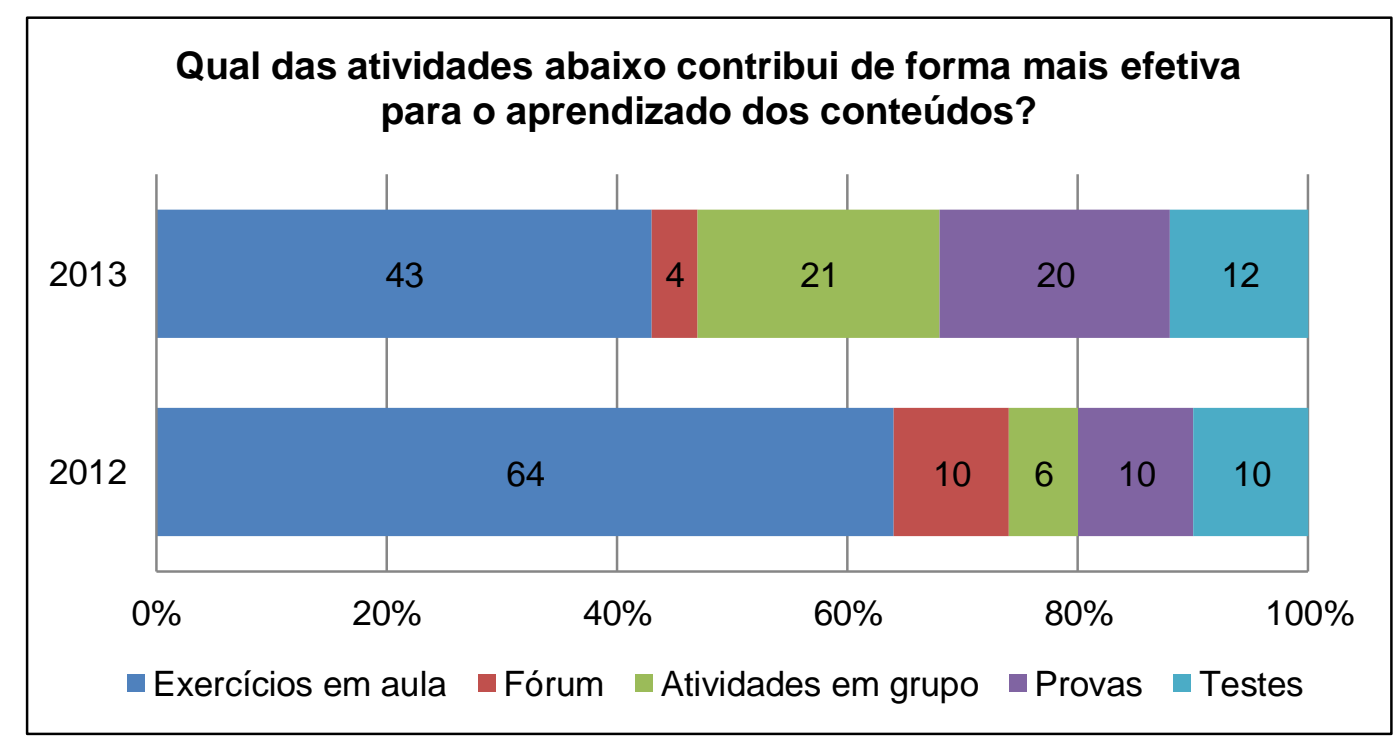

Figura 4.22: Diferenças relativas a atividade que mais contribuiu para o aprendizado dos conteúdos da disciplina

Com relação aos procedimentos conduzidos na disciplina, conforme a Figura 4.23, pode-se perceber que existe uma maior possibilidade dos alunos da Turma de 2013 cursarem outras disciplinas com a mesma abordagem da disciplina que mesclou atividades em sala de aula, aprendizagem ativa e atividades online.

Na questão relativa à facilidade de aprender o conteúdo da disciplina pelo modo tradicional, de acordo com a Figura 4.24, o percentual de alunos da Turma 2013 que discordaram desta afirmação foi relativamente maior que o percentual apresentado pela Turma de 2012. Estes resultados estão alinhados com os resultados relativos aos da Figura 4.23. Os alunos da Turma de 2013 são mais receptivos à abordagem da disciplina de Planejamento e Análise de Sistemas de Transportes do que de disciplinas em formato tradicional. 


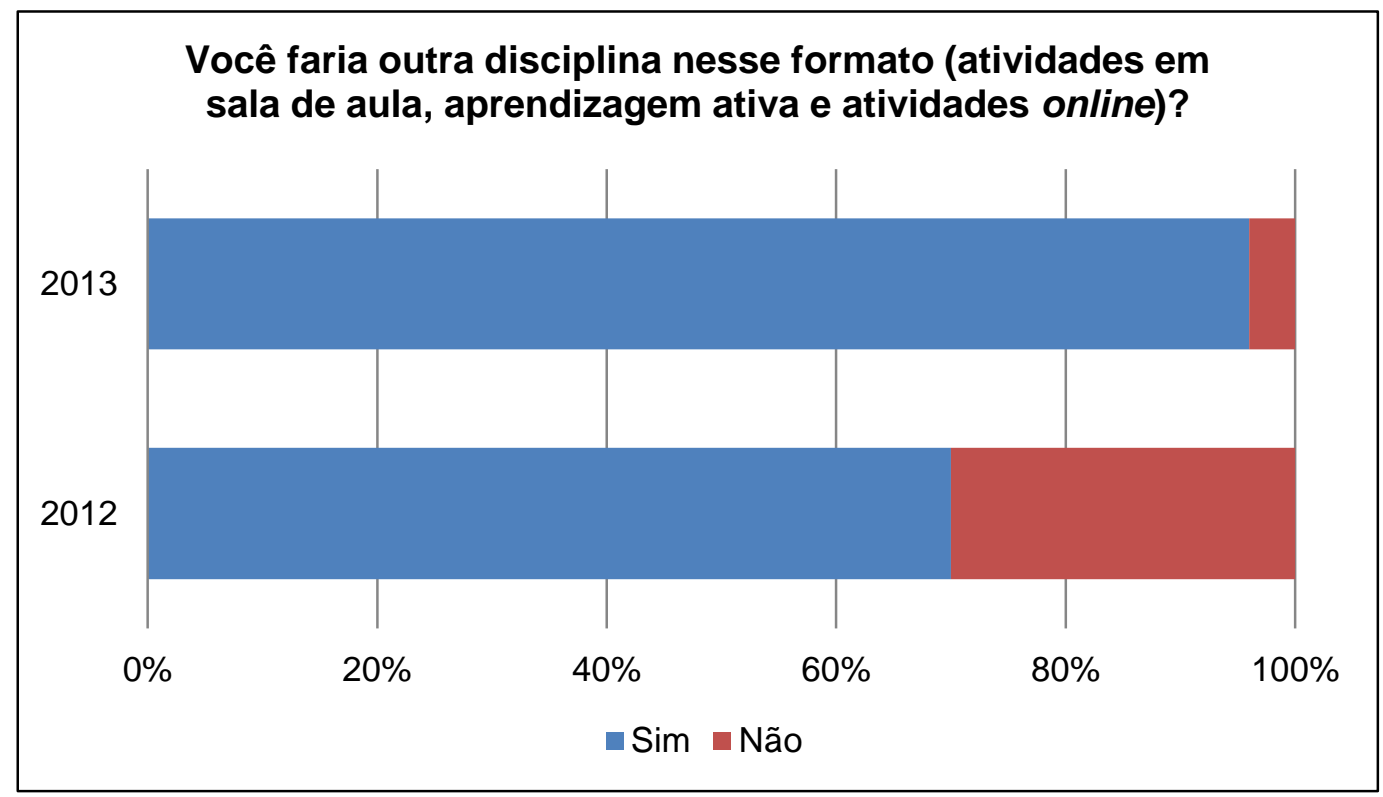

Figura 4.23: Diferenças relativas a atividade que mais contribuiu para o aprendizado dos conteúdos da disciplina

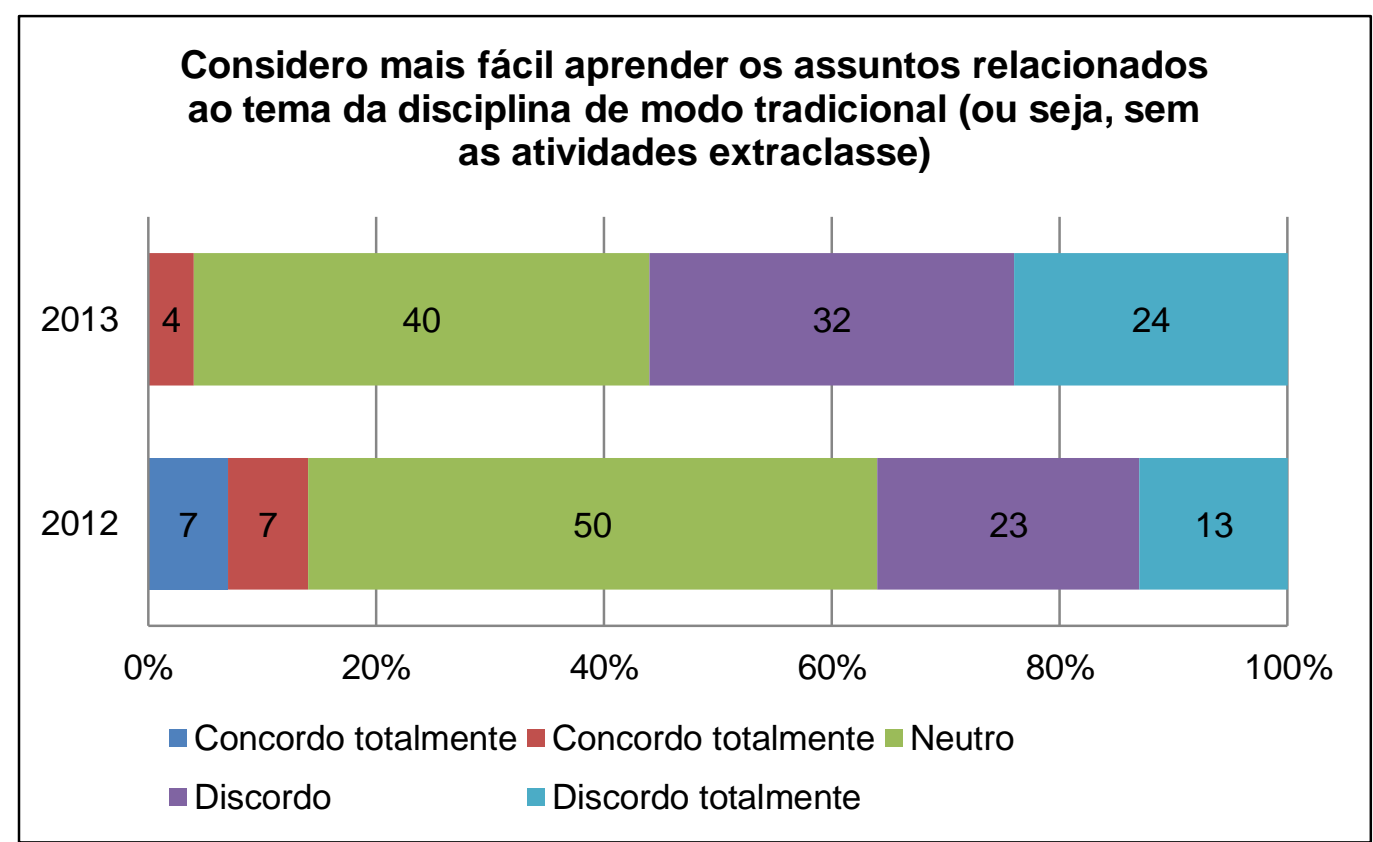

Figura 4.24: Diferenças sobre a receptividade a disciplinas que mesclam aulas tradicionais e aprendizagem ativa em relação a disciplinas que são puramente tradicionais

A utilização do ambiente colaborativo TIDIA-Ae apresentou os maiores percentuais de diferenças entre as turmas de 2012 e de 2013. De acordo com os gráficos das Figuras 4.25 a 4.28, pode-se tecer as seguintes análises: i) a quantidade de alunos que já havia acessado o Tidia-Ae antes das atividades conduzidas na disciplina de Planejamento $e$ Análise de Sistemas de Transportes foi muito maior na Turma 2013 do que na Turma de 2012 (Figura 4.25) o que pode ter favorecido muito as atividades neste ambiente 
colaborativo; ii) também os alunos da Turma de 2013 acharam a utilização do Tidia-Ae muito melhor, conforme a Figura 4.26; iii) da mesma forma a Turma de 2013 considerou mais simples e adequada a navegação pelo ambiente online (Figura 4.27); e iv) numa avaliação geral, a Turma de 2013, avaliou melhor o sistema Tidia-Ae (Figura 4.28).

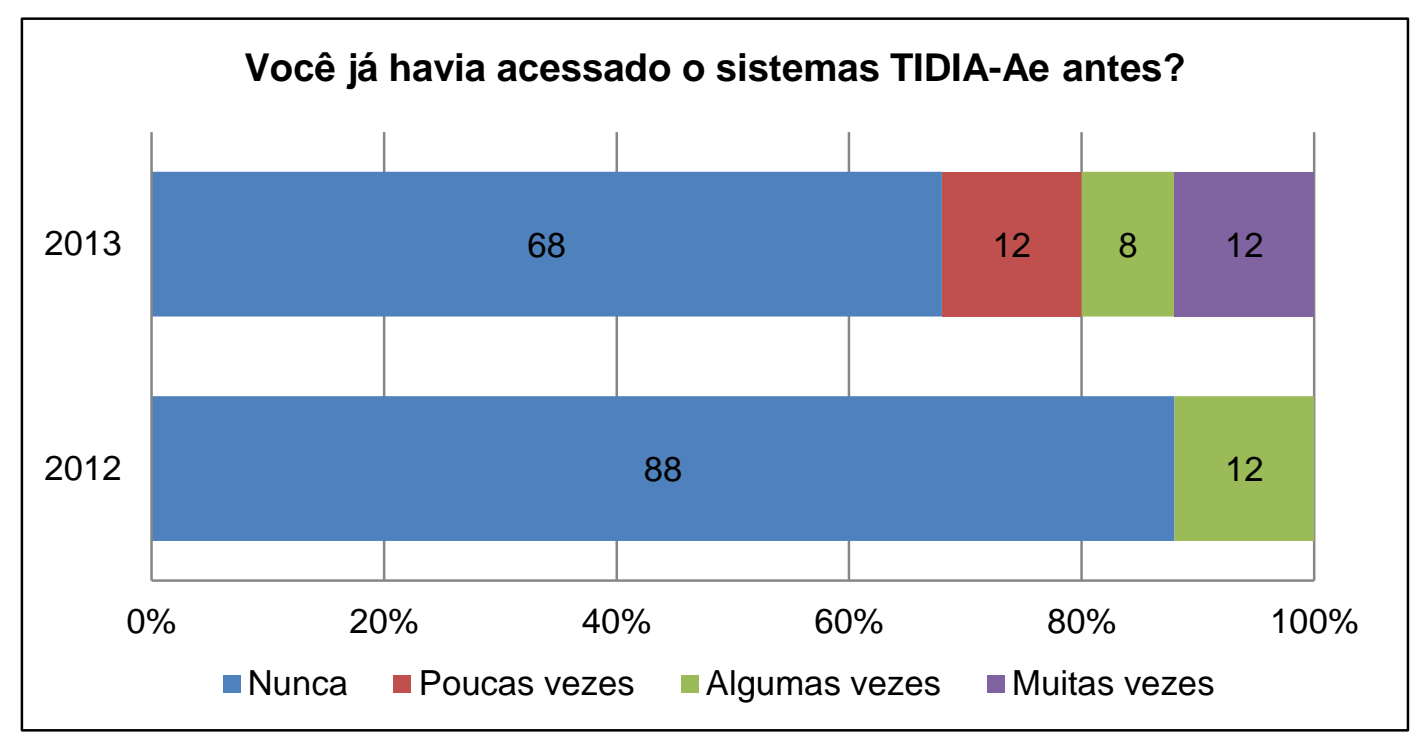

Figura 4.25: Diferenças entre os percentuais de alunos que já havia acessado o sistema TIDIA-Ae

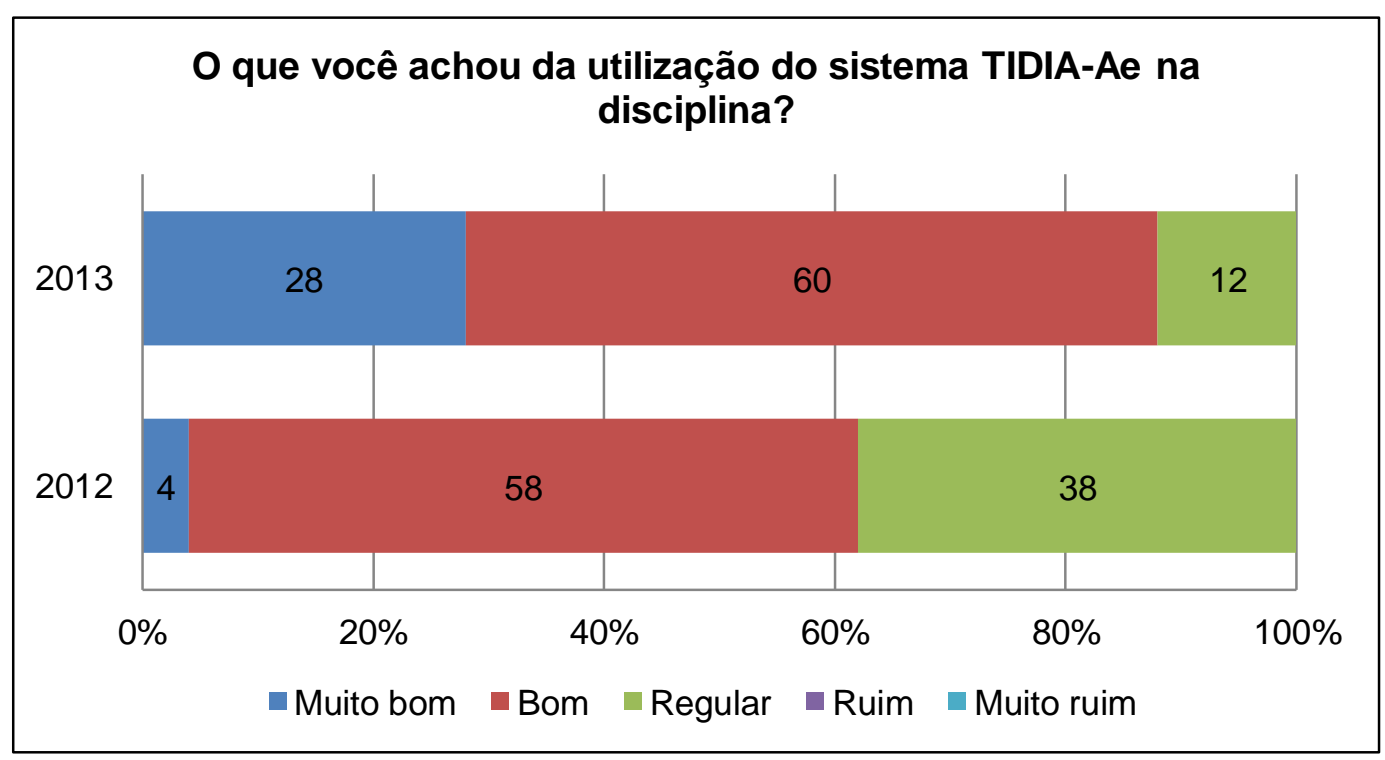

Figura 4.26: Diferenças entre os percentuais de alunos na utilização do sistema TIDIA-Ae 


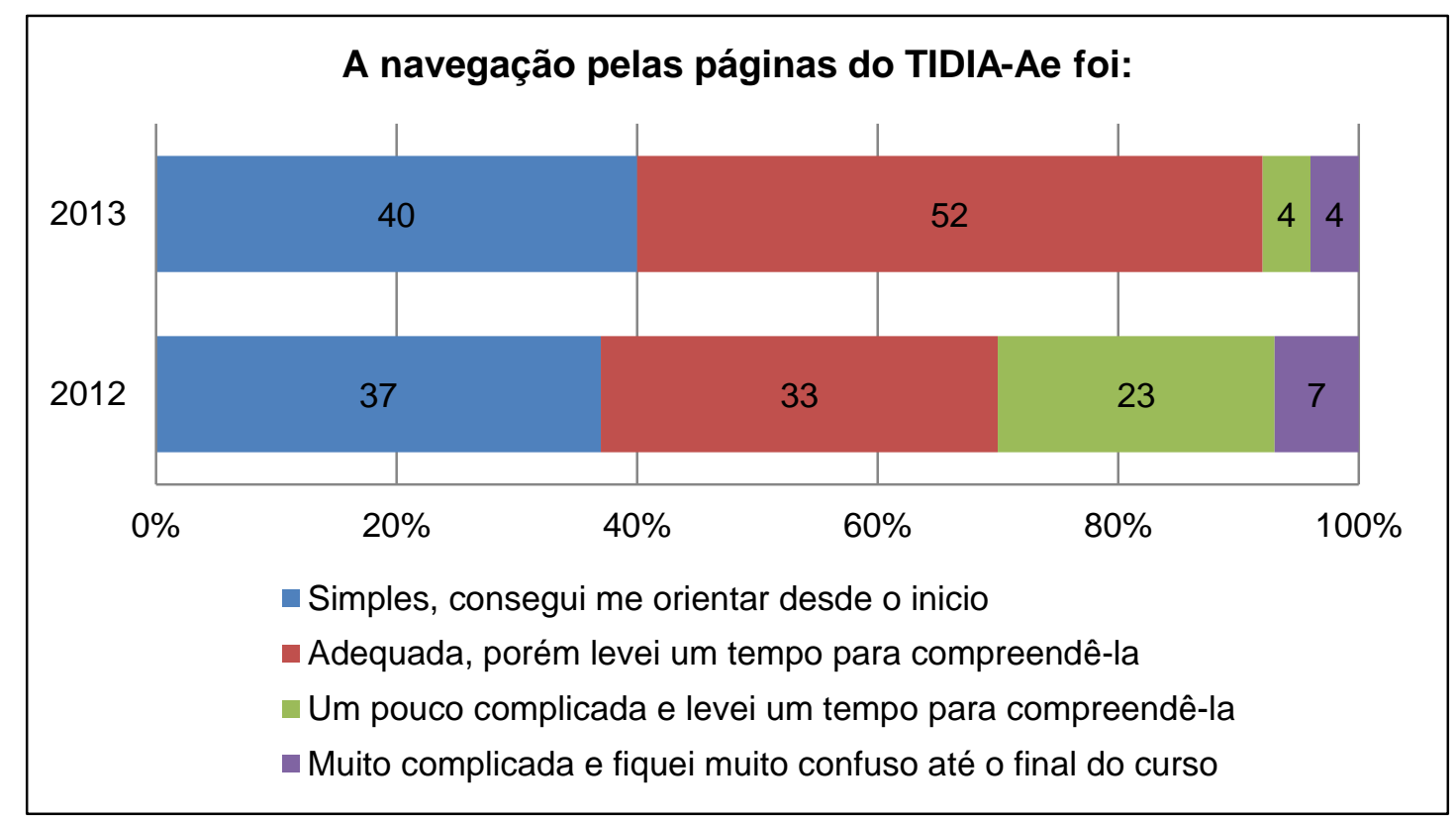

Figura 4.27: Diferenças entre os percentuais de alunos sobre a navegação nas páginas do sistema TIDIA-Ae

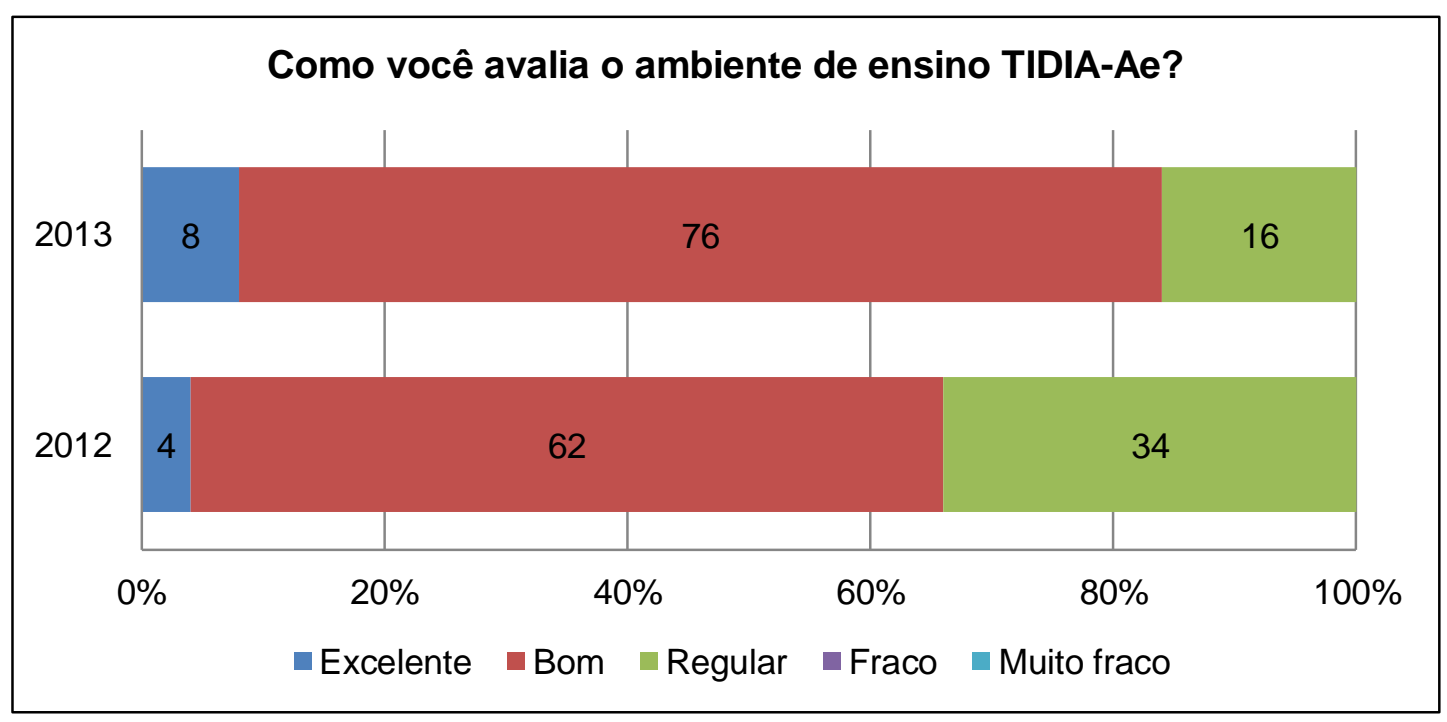

Figura 4.28: Diferenças entre os percentuais de alunos sobre a avaliação do TIDIA-Ae

De um modo geral, a utilização do ambiente colaborativo Tidia-Ae foi muito favorecida pelo fato dos alunos da Turma de 2013 terem tido contato prévio com esta ferramenta. Isto ajuda a vencer certos receios e pré-conceitos em relação a este tipo de ferramenta educacional. $O$ fato da Turma de 2013 ter avaliado a utilização do Tidia-Ae entre bom a excelente, com percentual de $84 \%$, conforme a Figura 4.28, pode ser considerada uma evolução benéfica, para o caso específico deste estudo, em termos de utilização de ambientes colaborativos online. Isto também pode indicar que outros docentes da instituição estejam utilizando regularmente esta ferramenta. 


\subsection{Ensino-aprendizagem - Avaliação do produto: mapas conceituais}

Os mapas conceituais foram utilizados neste estudo para atestar evidências de aprendizagem significativa e como forma de aperfeiçoar a avaliação do processo de ensinoaprendizagem. Os alunos construíram três versões de mapas sobre o tema geral da disciplina nos anos de 2012 e 2013. Foi solicitada ainda a construção de outros mapas, sobre temas diversos, com a finalidade de familiarizar os alunos com o uso do software CmapTools e o próprio processo de construção de mapas. A primeira versão do mapa foi construída na aula inicial da disciplina. O objetivo principal foi descobrir o que os alunos já sabiam sobre Planejamento e Análise de Sistemas de Transportes. A segunda versão foi construída antes do início da atividade da metodologia da problematização (para a Turma de 2012 e para a Turma 2 de 2013). Foi planejada para se ter uma ideia da evolução dos alunos em relação ao domínio dos conceitos e de suas inter-relações até aquele momento. A terceira e última versão foi feita ao final da disciplina. Os mapas conceituais foram analisados conforme os aspectos já mencionados na seção 3.3 da metodologia.

\subsubsection{Avaliação geral dos mapas conceituais}

Os mapas conceituais apresentaram indicativos de Aprendizagem Significativa e evidências de que podem auxiliar e aperfeiçoar o processo de avaliação da aprendizagem. Tornaram a avaliação mais abrangente e fidedigna em relação à evolução cognitiva, domínio conceitual e domínio de relação conceitual para o caso específico deste estudo. Vale ressaltar que mesmo sendo um procedimento de análise qualitativo, a avaliação dos mapas foi feita com base em critérios claros e previamente definidos (conforme seção 3.3). Estes critérios foram estabelecidos e usados para evitar análises tendenciosas e marcadas por um conjunto muito grande e diversificado de elementos de avaliação.

As análises dos mapas conceituais, em um primeiro momento, foram feitas para cada turma e serão apresentadas na seguinte ordem: Turma de 2012; Turma 1 de 2013 e Turma 2 de 2013. Em um segundo momento serão realizadas análises comparativas em função dos critérios adotados para análise dos mapas. Estas análises têm como objetivo apontar diferenças no processo de construção dos mapas conceituais. Estas diferenças construtivas dos mapas referem-se principalmente à comparação dos resultados do ano letivo de 2012 para os de 2013. 


\subsubsection{Avaliação dos mapas conceituais - Turma de 2012}

$\mathrm{Na}$ Figura 4.29 tem-se um resumo geral da avaliação das três versões dos mapas conceituais construídos pelos alunos da Turma de 2012. Com relação aos critérios Conceitos Introduzidos - COI e Importância dos Conceitos Introduzidos - ICOI pode-se concluir que os alunos introduziram poucos conceitos e isto pode ter resultado do fato de que a lista de sugestões de conceitos era relativamente extensa, com 30 sugestões. Em relação ao critério Evolução nas três Versões dos Mapas Conceitais - EVMC pode-se avaliar que $88 \%$ dos alunos obtiveram evolução em seus mapas, mas pode-se fazer a seguinte distinção: i) 50\% tiveram uma forte evolução; ii) 31\% apresentaram evolução moderada; e iii) $8 \%$ apresentaram fraca evolução. Do percentual de alunos que obteve evolução moderada, $15 \%$ construíram bons mapas desde a primeira versão e esta avaliação permaneceu nos demais mapas (estes dados não podem ser identificados na Figura 4.29). O mesmo aconteceu com os alunos que tiveram fraca evolução, pois todos também construíram bons mapas desde o início. Isto pode estar relacionado ao fato de que estes alunos já tinham cursado algumas disciplinas optativas antes da disciplina obrigatória de planejamento e análise de sistemas de transportes.

No que diz respeito ao critério Relação entre valores atribuídos ao Mapa Conceitual final e à Média Final - RMCMF, podem ser feitas as seguintes considerações: $46 \%$ dos alunos apresentaram forte relação entre a avaliação quantitativa atribuída aos mapas e suas médias finais. Em $12 \%$ dos casos a relação foi moderada e em $4 \%$ dos casos foi fraca. Dos $46 \%$ e $12 \%$ dos alunos que tiveram forte a moderada relação entre a avaliação quantitativa dos mapas e a média final, foi constatado ainda que: $31 \%$ obtiveram média final ruim, mas construíram bons mapas, 4\% tiveram média final boa e construíram mapas pobres e $8 \%$ tiveram média final ruim e construíram mapas pobres (isto não está visível na Figura 4.29). Isto parece indicar que o uso de mais de um instrumento de avaliação pode auxiliar o professor a tomar decisões mais precisas sobre a avaliação da aprendizagem dos alunos. 


\section{Aspectos Positivos}

Características comuns nas versões do mapa - CCM

Problemas recorrentes - PBR

Evolução dos mapas nas três versões - EVMC

Dificuldade para a construção dos mapas - DCMC

Conceitos preservados nas três versões - CPMC

Relação direta entre o mapa e a média final - RMCMF
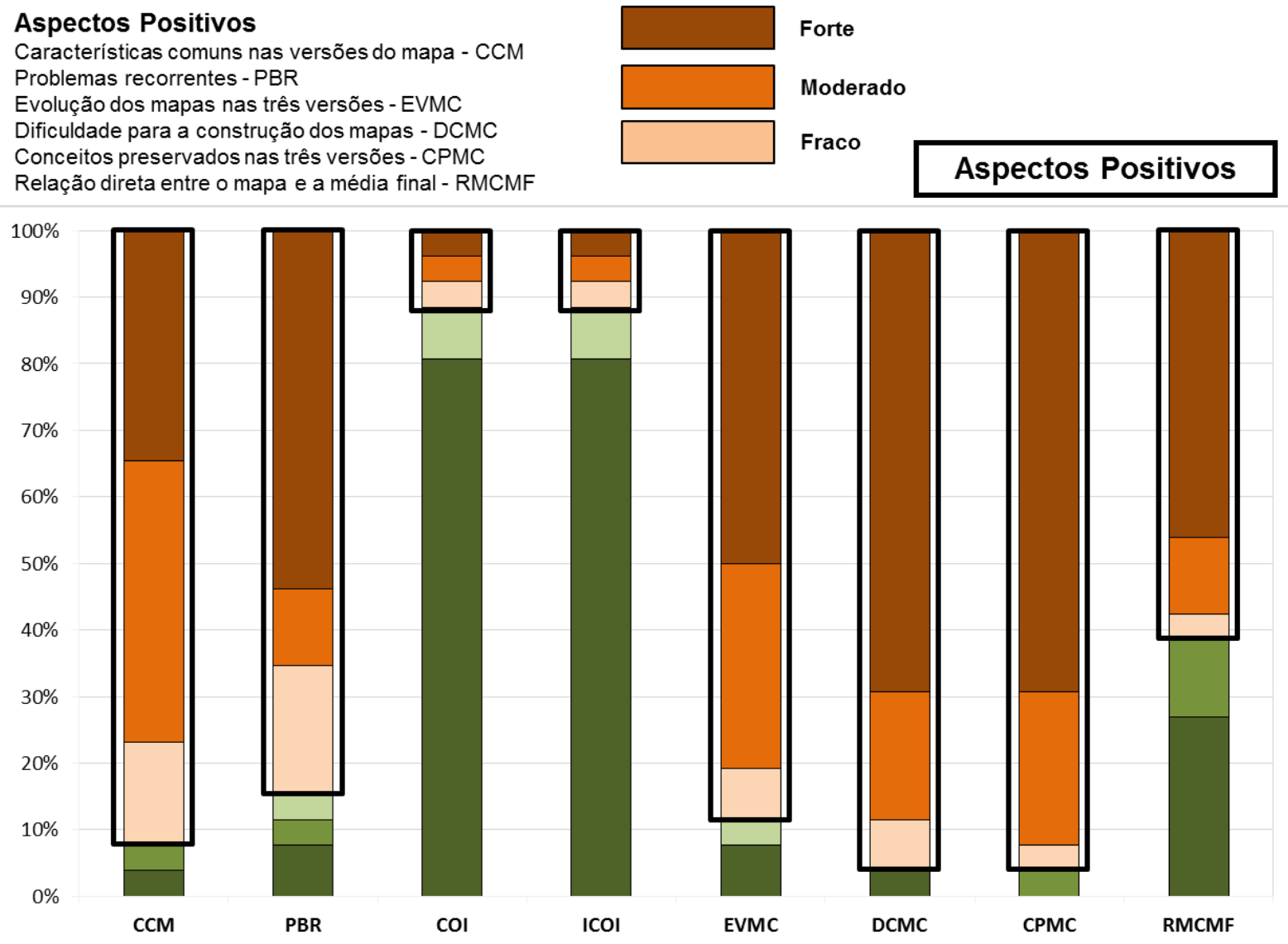

\section{Aspectos Negativos}

Conceitos introduzidos - $\mathrm{CO}$

Importância dos conceitos Introduzidos - ICOI

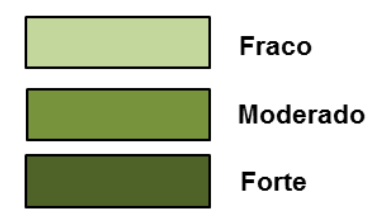

Aspectos Negativos

Figura 4.29: Avaliação geral dos mapas conceituais - Turma 2012

\subsubsection{Avaliação dos mapas conceituais - Turma 1 de 2013}

A análise dos mapas da Turma 1 de 2013 indicou os seguintes aspectos, conforme a Figura 4.30. A maioria dos alunos, $83 \%$, construiu mapas que tinham Características Comuns nas versões, de forma moderada a forte. Isso significa que os mesmos construíram uma estrutura básica inicial e a partir desta estrutura passaram a inserir novos conceitos, ajustar as relações entre os conceitos e/ou criar relações na forma de reconciliação integrativa. Por outro lado, $17 \%$ dos alunos mudaram de forma fraca a moderada as características de seus mapas ao longo da construção das três versões. Isso pode evidenciar que esses alunos ainda não tinham conseguido visualizar a estrutura básica do tema dos mapas nas primeiras versões ou que eles ainda não estavam seguros quanto às relações conceituais que poderiam fazer. 


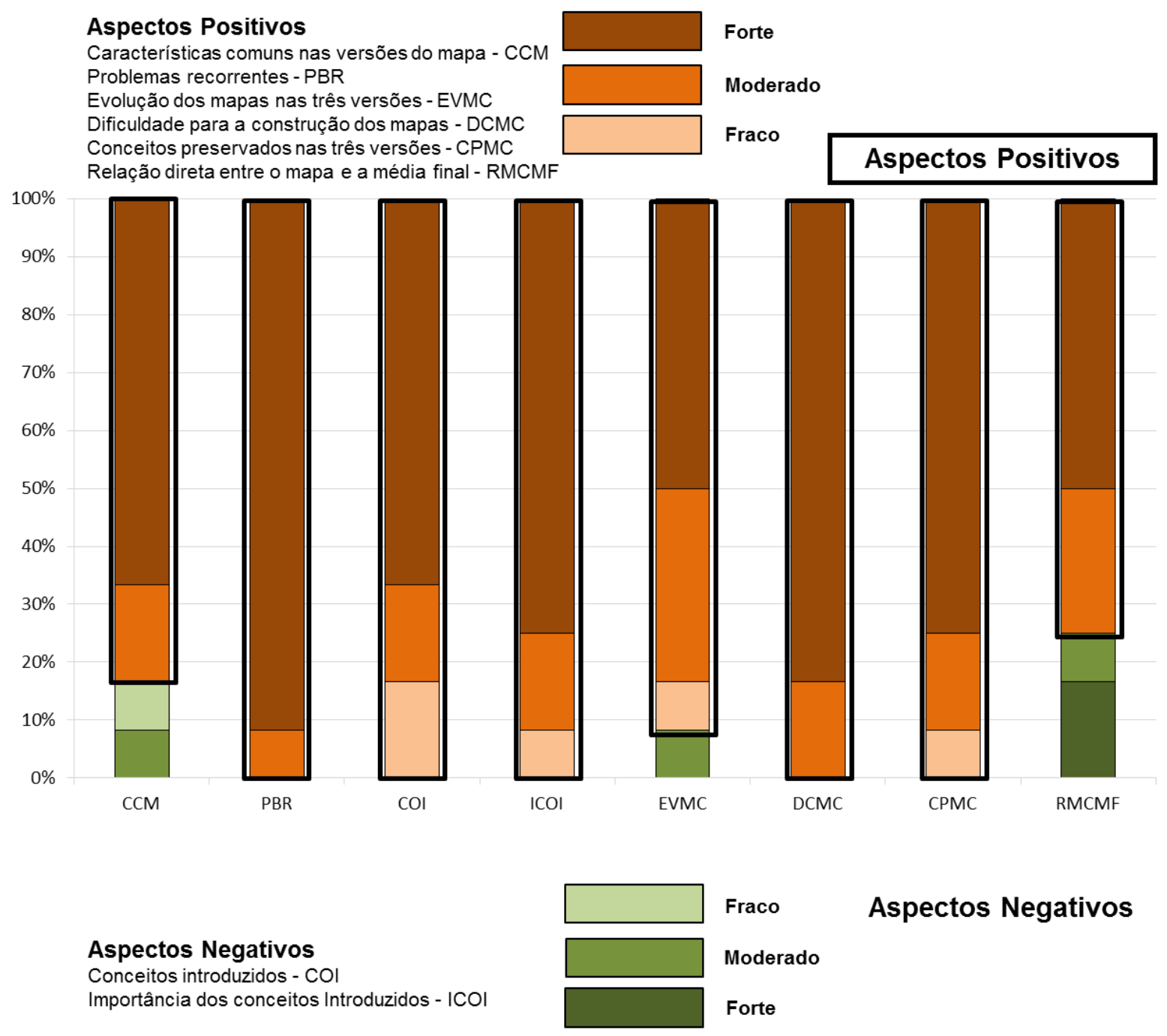

Figura 4.30: Avaliação geral dos mapas conceituais - Turma 1 - 2013

Outro aspecto que ficou muito nítido para a Turma 1 de 2013, conforme a Figura 4.30, foi com relação a Problemas Recorrentes. Observa-se que 100\% dos mapas construídos não apresentavam Problemas Recorrentes. Isto possibilita afirmar que os mapas não possuíam equívocos conceituais ou de relações conceituais.

Com relação aos itens Conceitos Introduzidos e Importância dos Conceitos Introduzidos, pode-se afirmar, de acordo com a Figura 4.30, que 100\% dos alunos introduziram conceitos e estes eram importantes. Estes conceitos introduzidos tornavam possível a leitura dos mapas, pois permitiam o estabelecimento de relações conceituais sobre o tema. No caso dos Conceitos introduzidos tem-se que $17 \%$ dos alunos fizeram isso de forma fraca, ou seja, não mais do que 10 conceitos. Os demais alunos, isto é, 17\% e 66\%, introduziram conceitos de forma moderada ou forte, respectivamente. No caso da Importância dos Conceitos Introduzidos pode-se fazer a seguinte divisão: fraca (8\%); moderada (17\%) e forte $(75 \%)$. 
A Evolução nas três Versões dos Mapas Conceituais pode refletir o nível de aprendizagem significativa dos alunos. Esta aprendizagem pode ser interpretada como a facilidade para conduzir as diferenciações progressivas e principalmente para realizar as reconciliações integrativas. Conforme a Figura 4.30, 92\% dos mapas construídos apresentaram evolução, sendo $8 \%$ fraca, $34 \%$ moderada e $50 \%$ forte. Os demais mapas, ou seja, $8 \%$ não tiveram evolução e isso ocorreu de forma moderada.

Nenhum aluno, conforme a análise da Figura 4.30, apresentou Dificuldade para a Construção dos Mapas Conceituais. Isso permite supor que eles entenderam as questões relativas à diferenciação progressiva, emprego das frases ou palavras de ligação, o uso do software CmapTools e a finalidade dos mapas neste experimento. No caso dos Conceitos Preservados nas três versões dos Mapas Conceituais, tem-se que, em 100\% dos casos, foram mantidos os conceitos sugeridos para a construção dos mapas e aqueles que foram introduzidos posteriormente pelos próprios alunos.

A Relação entre valores atribuídos ao Mapa Conceitual final e à Média Final, conforme a Figura 4.30 , ocorreu com $75 \%$ dos alunos. Neste caso, $25 \%$ de forma moderada e $50 \%$ forte. Sendo assim, tem-se que houve uma relação direta, ou seja, a média final estava muito próxima da nota atribuída ao mapa. Porém, em $25 \%$ dos casos houve discordância entre a média dos alunos e o mapa. Nesta situação tem-se que: a relação foi inversa, pois houve casos em que a média final foi menor que a nota atribuída ao mapa, ou a média final foi maior do que anota atribuída ao mapa.

\subsubsection{Avaliação dos mapas conceituais - Turma 2 de 2013}

A análise dos mapas da Turma 2 de 2013 indicou os seguintes aspectos, conforme a Figura 4.31. Todos os alunos, $100 \%$, construíram mapas que tinham Características Comuns nas versões dos mapas conceituais, de forma moderada a forte. Isso significa que os mesmos construíram uma estrutura básica inicial e a partir desta estrutura passaram a inserir novos conceitos, ajustar as relações entre os conceitos e/ou criar relações na forma de reconciliação integrativa. Outro aspecto que ficou nítido para a Turma 2 de 2013, conforme a Figura 4.31, foi com relação a Problemas recorrentes. Observa-se que $70 \%$ dos mapas construídos não apresentavam Problemas recorrentes (moderada a forte). Porém, em 30\% dos mapas foram encontrados problemas (fraco a moderado), tais como: dificuldades para encontrar frases de ligação coerentes entre os conceitos; ausência do conceito-chave planejamento e não entendimento da diferenciação progressiva. Vale ressaltar que estes 
problemas ocorreram principalmente nas versões 1 e 2 dos mapas e que a maioria foi resolvido até a construção da versão final.

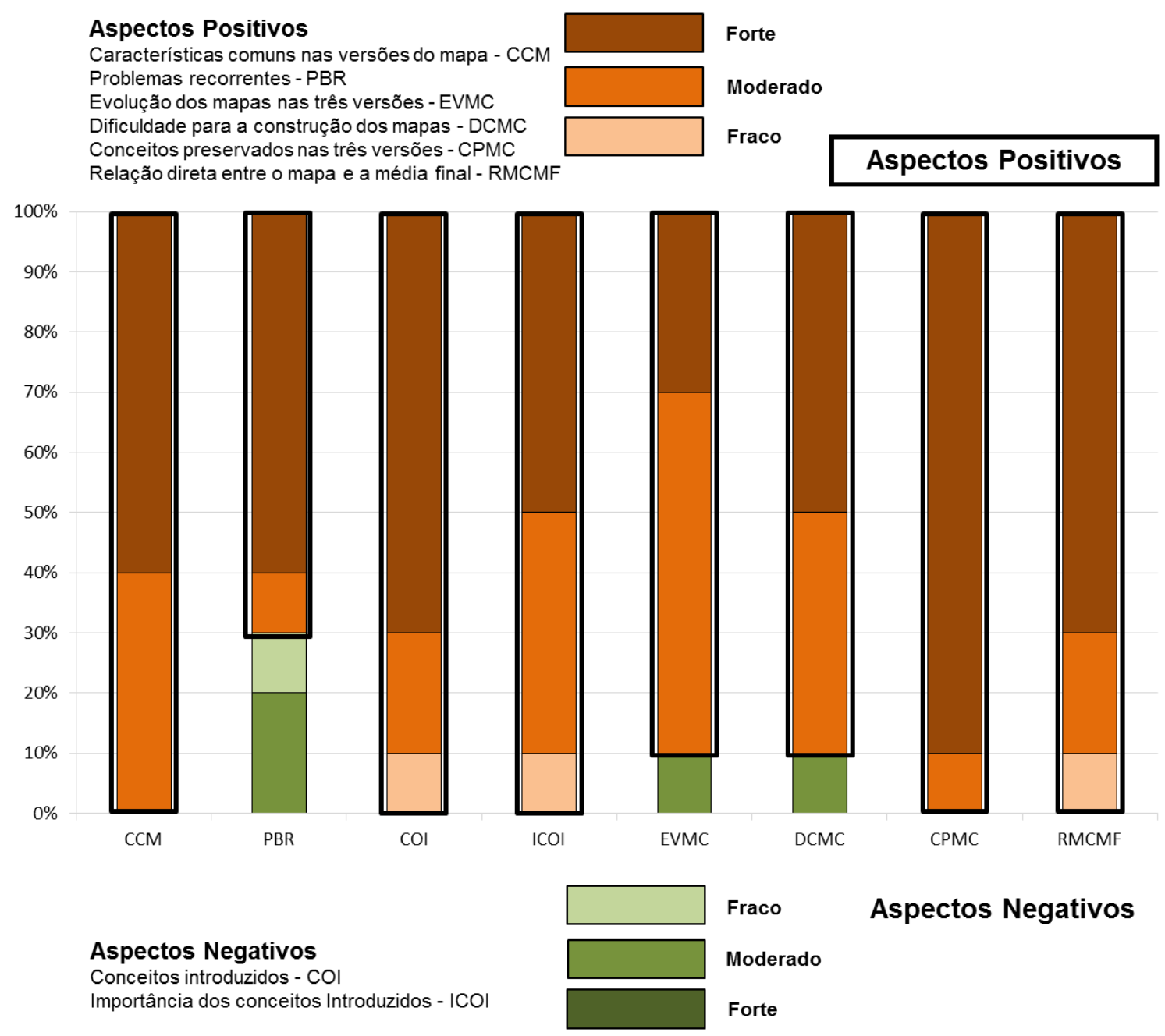

Figura 4.31: Avaliação geral dos mapas conceituais - Turma 2 - 2013

Com relação aos itens Conceitos Introduzidos e Importância dos Conceitos Introduzidos, pode-se afirmar, de acordo com a Figura 4.31, que 100\% dos alunos introduziram conceitos e estes eram relevantes para o mapa. Estes conceitos introduzidos tornavam possível a leitura dos mapas, pois geravam a possibilidade de realizar as relações conceituais sobre 0 tema. No caso dos Conceitos Introduzidos tem-se que $10 \%$ dos alunos fizeram isso de forma fraca, ou seja, não mais do que 10 conceitos. Os demais alunos, isto é, $20 \%$ e $70 \%$, apresentaram conceitos de forma moderada ou forte, respectivamente. No caso da Importância dos Conceitos Introduzidos pode-se fazer a seguinte divisão: fraca (10\%); moderada ( $40 \%)$ e forte $(50 \%)$. 
A Evolução nas três Versões dos Mapas Conceituais pode refletir o nível de aprendizagem significativa dos alunos. Esta aprendizagem pode ser interpretada como a facilidade para conduzir as diferenciações progressivas e principalmente para realizar as reconciliações integrativas. Conforme a Figura 4.31, 90\% dos mapas construídos apresentaram evolução, sendo $60 \%$ moderada e $30 \%$ forte. Os demais mapas, ou seja, $10 \%$, não tiveram evolução e isso ocorreu de forma moderada.

Conforme a análise da Figura 4.31, 10\% dos alunos apresentaram Dificuldade para a Construção dos Mapas Conceituais. Neste caso a dificuldade foi moderada. Isso pode estar relacionado à questão dos Problemas Recorrentes, conforme apresentado anteriormente. No caso dos Conceitos Preservados nas três versões dos Mapas Conceituais, tem-se que $100 \%$ mantiveram os conceitos sugeridos para a construção dos mapas e aqueles que foram introduzidos posteriormente pelos próprios alunos.

A Relação entre valores atribuídos ao Mapa Conceitual final e à Média Final, conforme a Figura 4.31 , ocorreu em $100 \%$ dos casos. Sendo assim, tem-se que houve uma relação direta, ou seja, a média final estava muito próxima da nota atribuída ao mapa.

\subsubsection{Percepção dos alunos da Turma 2 de 2013 sobre os mapas conceituais}

Nesta seção são apresentados os resultados relativos a um questionário fornecido aos alunos da Turma 2 de 2013. O objetivo foi captar as impressões sobre o uso dos Mapas Conceituais e do software CmapTools na disciplina de Planejamento e Análise de Sistemas de Transportes. Este questionário era composto de nove perguntas diretas (ANEXO C perguntas 21 a 29), com a possibilidade de comentários. A forma de preenchimento do questionário foi por meio de uma plataforma online. As respostas às perguntas do questionário foram divididas em quatro temas: i) confecção dos mapas conceituais; ii) dificuldades para a construção dos mapas conceituais; iii) mapas conceituais como ferramenta de avaliação; e iv) percepção geral. Com relação à confecção dos mapas conceituais, conforme as Figuras 4.32 e 4.33, observa-se que tanto o tempo disponibilizado quanto a quantidade de conceitos sugeridos foram considerados suficientes para a construção das três versões dos mapas $(54 \%$ e $50 \%$ de respostas afirmativas, respectivamente). Ainda assim, a quantidade de alunos que disse ter dificuldades para a confecção dos seus mapas é considerável em comparação com a quantidade daqueles que não tiveram dificuldades, conforme a Figura 4.34. 


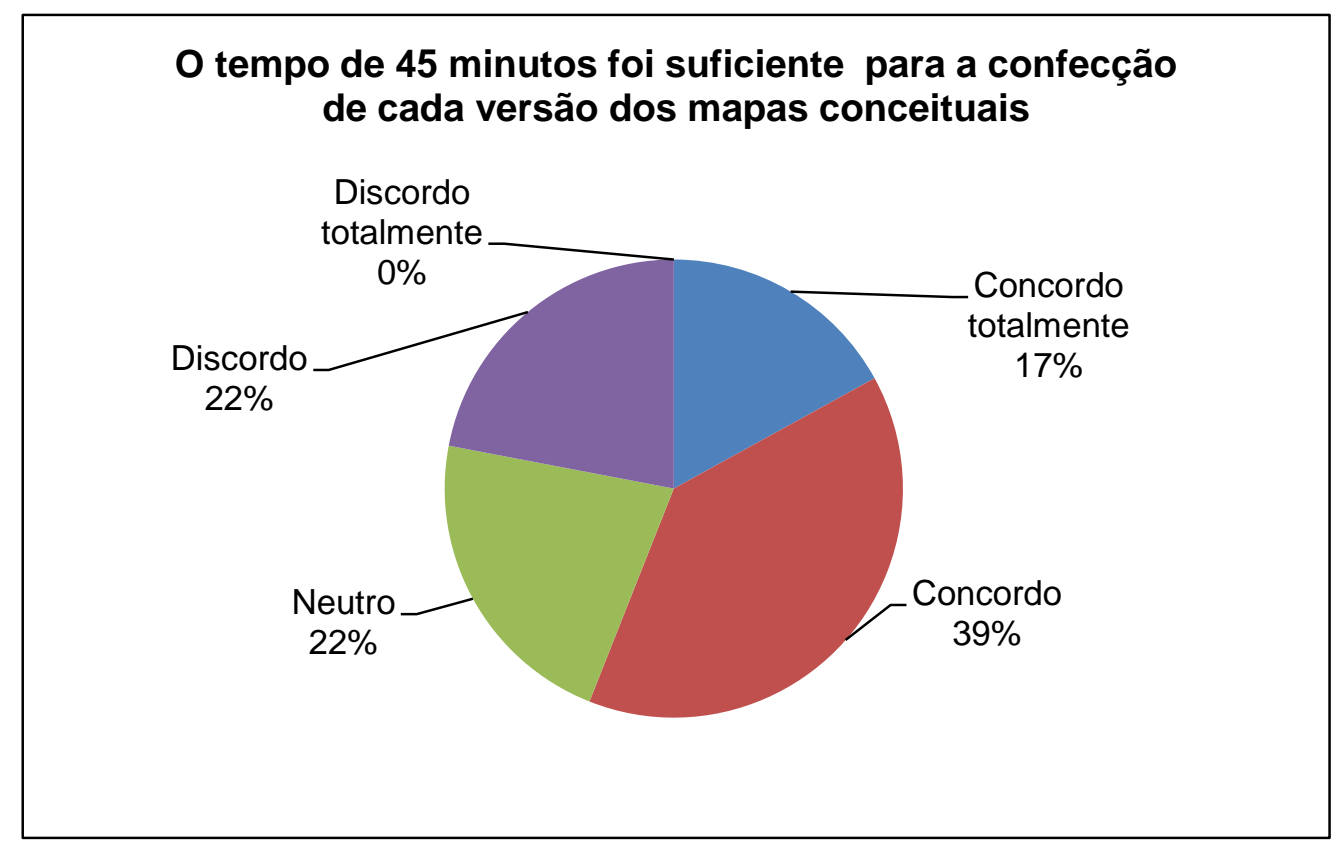

Figura 4.32: Percepção dos alunos em relação ao tempo disponível para a confecção dos mapas conceituais - Turma 2 de 2013

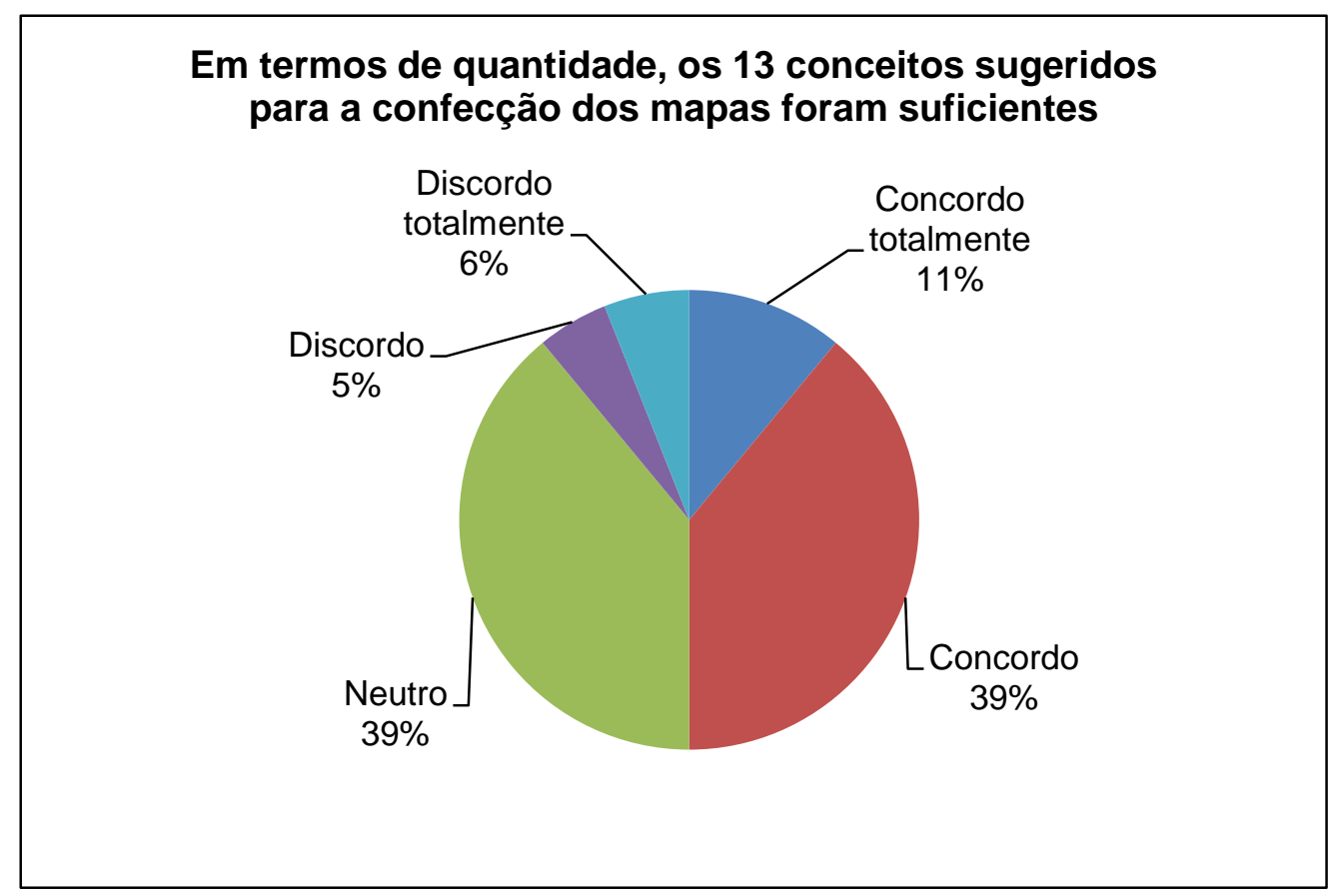

Figura 4.33: Percepção dos alunos em relação a quantidade de conceitos sugeridos para a confecção dos mapas conceituais - Turma 2 de 2013 


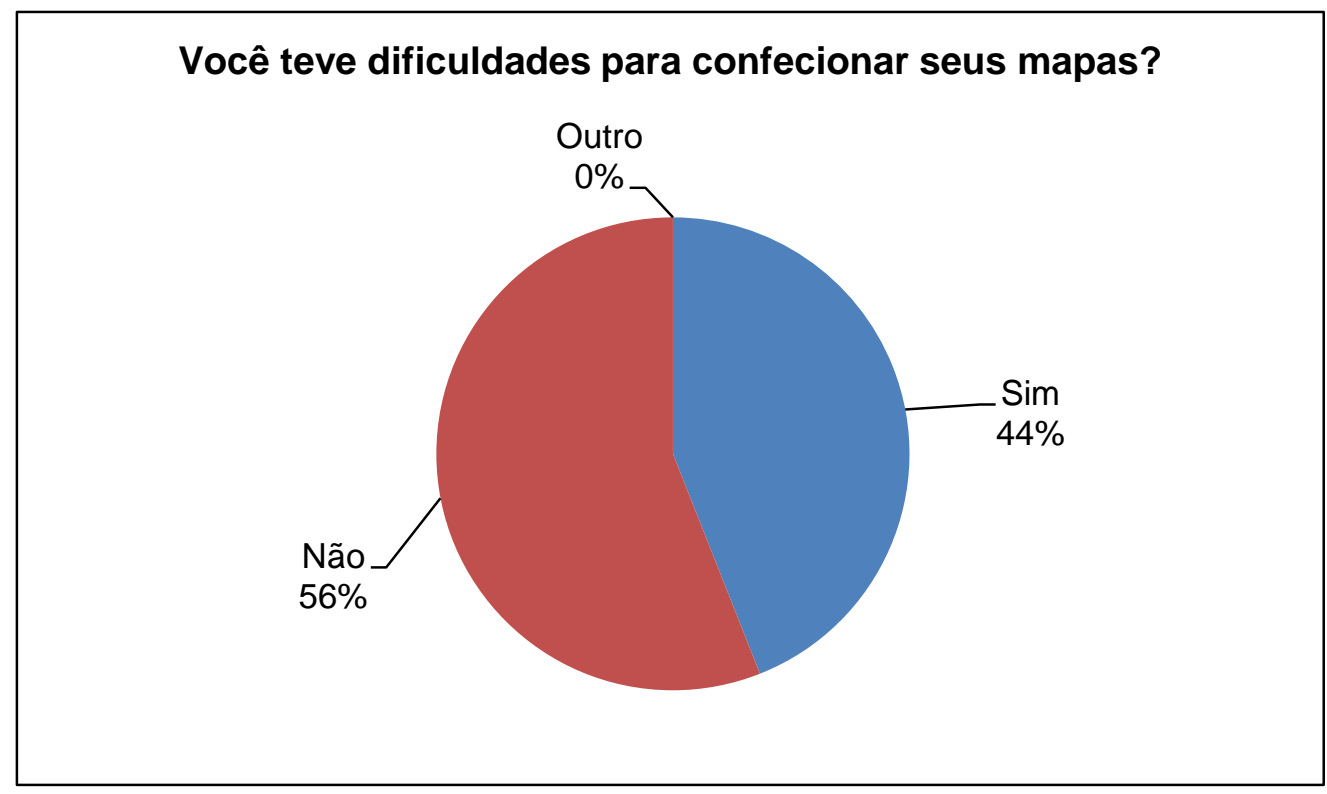

Figura 4.34: Percepção dos alunos em relação as dificuldades para confeccionar os mapas conceituais - Turmas 2 de 2013

Na Tabela 4.9 são apresentados os comentários de dois alunos a respeito da confecção dos mapas. São comentários com pontos de vista diferentes, mas que podem evidenciar que o tempo de contato com o instrumento mapa conceitual e a ferramenta para confecção dos mapas (CmapTools) são importantes para que o aluno possa se adaptar a este método de ensino-aprendizagem e avaliação.

Tabela 4.9: Comentários de alunos da Turma 2 - 2013 sobre a dificuldade para confecção de mapas conceituais.

Aluno Comentário

"Sigo uma linha de raciocínio muito contínua, e achei muito difícil expressar isso através

TB do mapa (ele parece exigir conexões de palavras e divisões de ideias que eu não costumo fazer, então não consegui fazer um mapa que me agradasse)."

"Por ter faltado em algumas aulas, fiz apenas um mapa conceitual. Porém, já tinha

FM trabalhado bastante com essa técnica no ensino médio, portanto não tive dificuldades na confecção."

Desta forma, observa-se na Figura 4.35 que apenas $17 \%$ dos alunos assinalaram que não tiveram nenhuma dificuldade para construir seus mapas. Os demais alunos indicaram suas principais dificuldades. Vale ressaltar que $6 \%$ dos alunos indicaram a opção "outra", mas 
não descreveram quais seriam essas outras dificuldades (embora houvesse um campo para este fim, se eles desejassem fazê-lo), conforme a Figura 4.35.

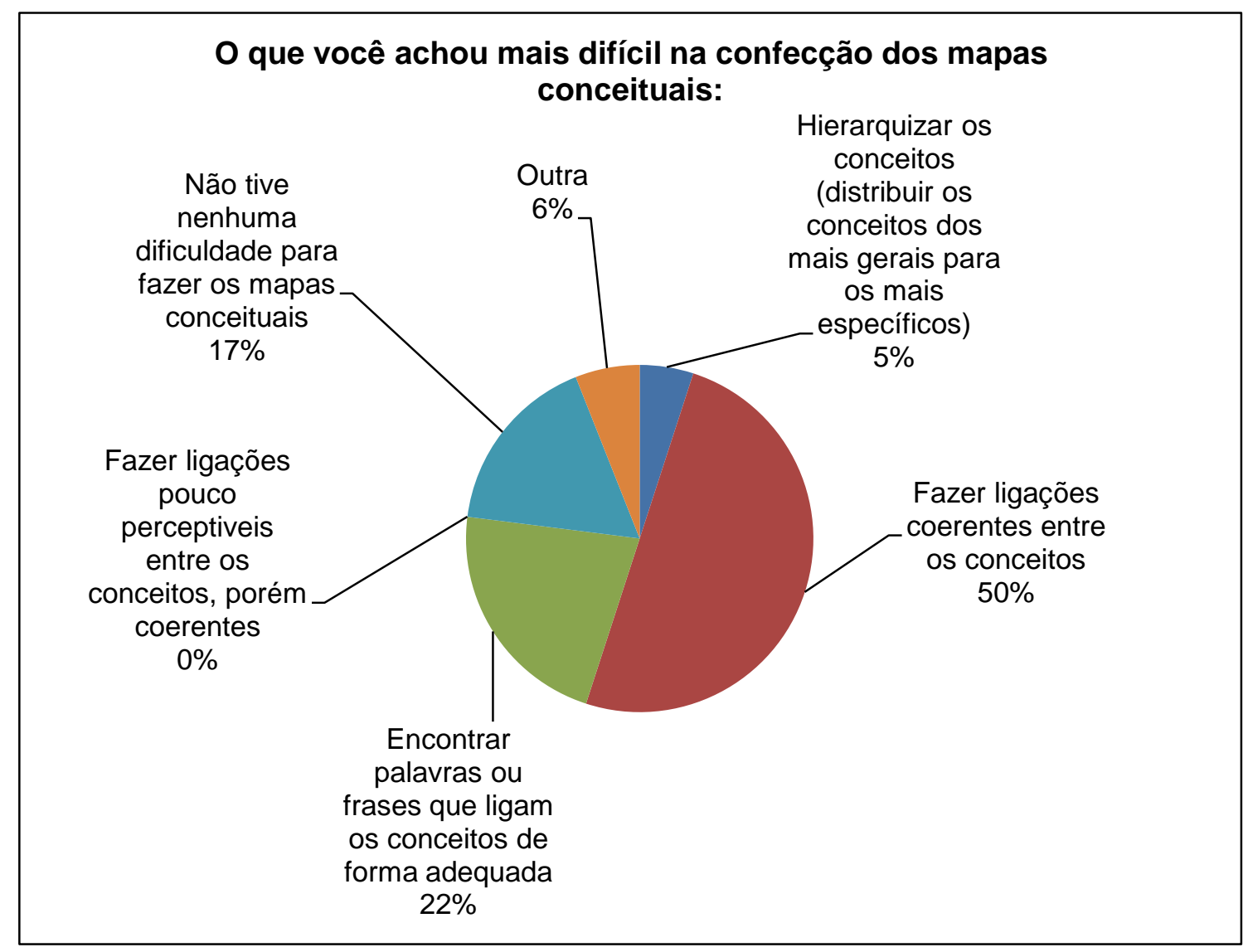

Figura 4.35: Percepção das dificuldades para a confecção dos mapas conceituais -

Turma 2 de 2013

Sobre a questão da dificuldade para construção dos mapas e o que pode ter sido mais difícil, na Tabela 4.10 são apresentados comentários de dois alunos. Observa-se que os comentários corroboram os resultados do gráfico da Figura 4.35, isto é, fazer ligações coerentes entre conceitos é relativamente mais difícil no processo de confecção de mapas conceituais.

O uso dos mapas conceituais como ferramenta de avaliação é uma preocupação tanto para professores quanto para alunos. Os alunos foram solicitados a expressarem suas opiniões a respeito da utilização dos mapas como ferramenta de avaliação do processo de ensino aprendizagem. Conforme a Figura 4.36, observa-se que a maioria dos alunos não faria uma disciplina que tivesse como único meio de avaliação a confecção de mapas conceituais. 
Tabela 4.10: Comentários de alunos da Turma 2 - 2013 sobre a maior dificuldade para confecção de mapas conceituais.

Aluno Comentário

BF "Todos os conceitos precisam está interligados de alguma forma."

TB

"Minha maior dificuldade foi "ramificar" os conceitos, para que a árvore não ficasse com apenas uma linha (literalmente) de raciocínio (com um conceito logo embaixo do outro)."

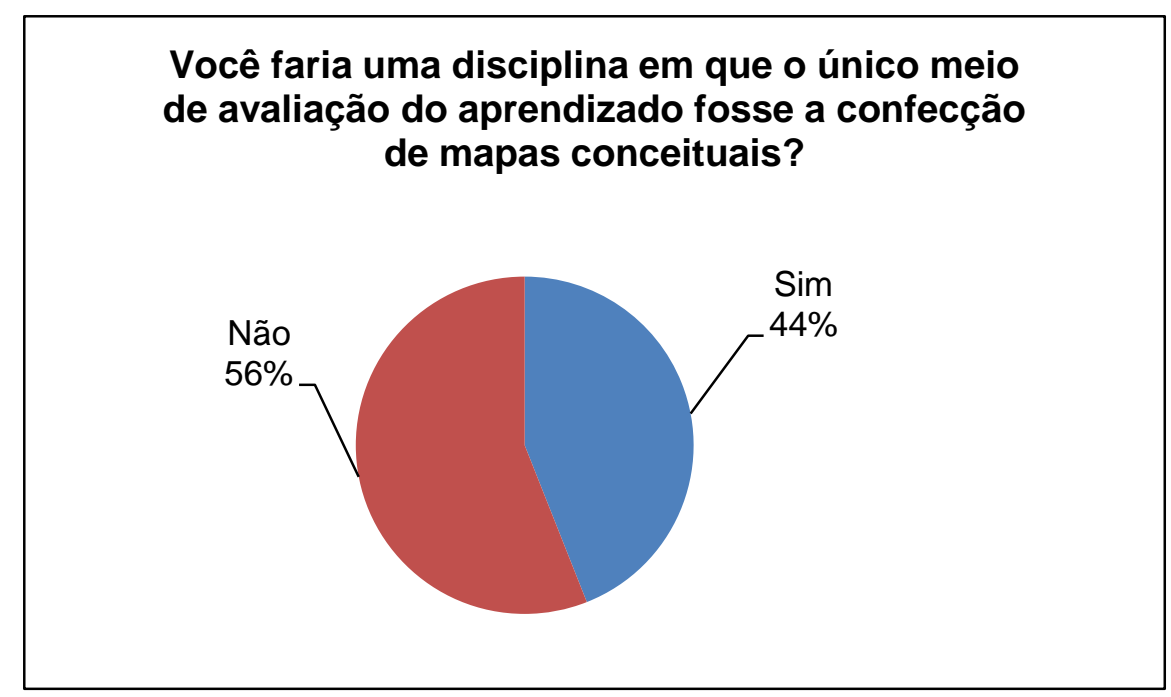

Figura 4.36: Percepção sobre o uso dos mapas conceituais como ferramenta da avaliação da aprendizagem - Turma 2 de 2013

A questão da avaliação da aprendizagem sempre despertou nos alunos, em geral, uma preocupação muito grande. Na Tabela 4.11 tem-se o comentário de dois alunos sobre o uso dos mapas conceituais como instrumento de avaliação do processo de ensinoaprendizagem. A pergunta do questionário que gerou estes comentários é a mesma que consta da Figura 4.36. O aluno JB respondeu "não" e o aluno DS respondeu "sim". Observase que existe uma preocupação dos alunos com relação ao uso dos mapas conceituais como ferramenta de avaliação em disciplinas do curso de Engenharia Civil. Porém, os comentários refletem o nível de amadurecimento destes alunos sobre a possibilidade do mapa ser usado como ferramenta de ensino-aprendizagem e avaliação de forma eficaz.

Desta forma, percebe-se certa maturidade e entendimento dos processos que podem estar envolvidos nesta questão da avaliação do aprendizado, principalmente em cursos de engenharia, que possuam relativa aplicação de procedimentos matemáticos e tecnológicos. Ficou claro, para o caso específico desta pesquisa, que quaisquer mudanças no processo 
de verificação ou avaliação precisam ser bem explicadas e processadas progressivamente. Alterações imediatas podem causar desconforto, descontentamento e até mesmo desaprovação em função das peculiaridades dos cursos de engenharia.

Tabela 4.11: Comentários de alunos da Turma 2 - 2013 sobre uso dos mapas conceituais como ferramenta de avaliação.

\begin{tabular}{cl}
\hline Aluno & $\begin{array}{l}\text { Comentário da questão: Você faria uma disciplina em que o único meio de avaliação do } \\
\text { aprendizado fosse a confecção de mapas conceituais? }\end{array}$ \\
\hline JB $\quad \begin{array}{l}\text { Não, trabalhos em campo e projetos são de extrema importância para um curso de } \\
\text { engenharia, em minha opinião. Penso que além de saber conceitos temos que saber } \\
\text { aplicá-los." }\end{array}$ \\
"SS $\quad \begin{array}{l}\text { gim, depende muito de como seria feito essa disciplina, pois teria que ser algo mais } \\
\end{array}$
\end{tabular}

Além disso, quando perguntados se a versão final do mapa conceitual poderia representar a média final obtida na disciplina, percebeu-se mais uma vez receio dos alunos sobre a questão da avaliação do processo de ensino-aprendizagem, conforme a Figura 4.37. Apesar de $45 \%$ dos alunos indicarem que achavam que a versão dos seus mapas poderiam representar suas médias finais na disciplina, 44\% e 11\%, respectivamente indicaram, as opções "não" e "outro".

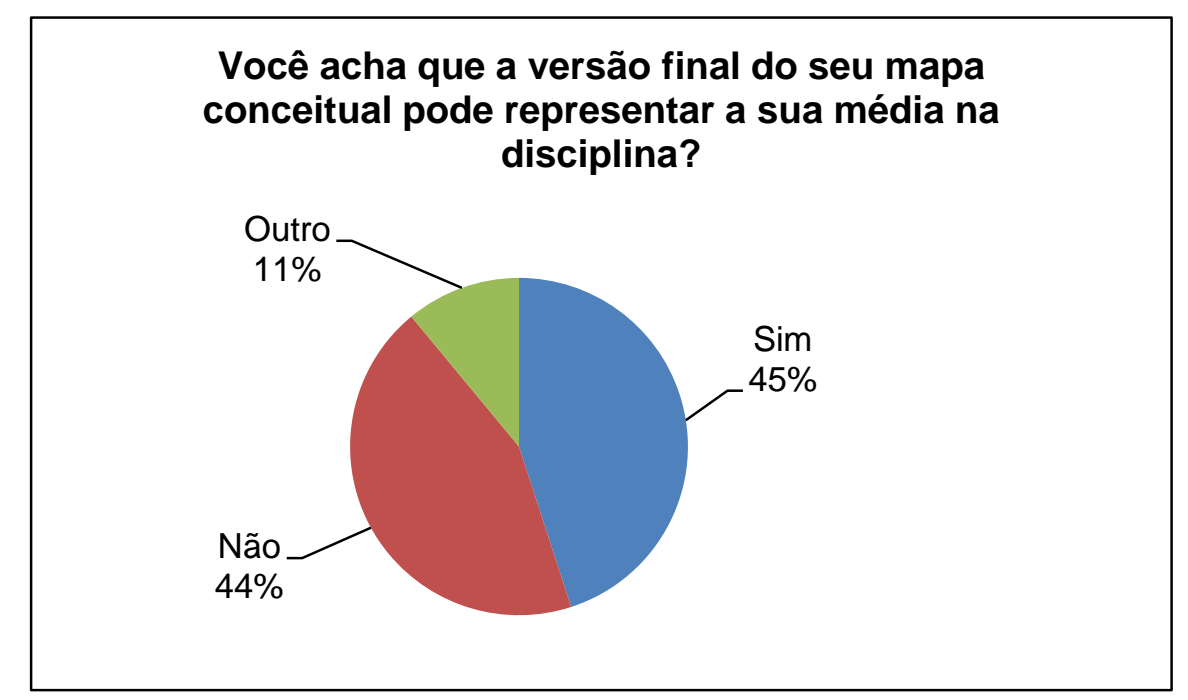

Figura 4.37: Percepção sobre a versão final do mapa conceitual ser representativa da média final na disciplina - Turma 2 de 2013 
Ao analisar as respostas ao questionário para a pergunta da questão que está na Figura 4.37, observa-se a preocupação dos alunos com os critérios de avaliação dos mapas e também com a representação quantitativa das médias tradicionais no processo de ensinoaprendizagem. Nos comentários apresentados na Tabela 4.12, o aluno CN respondeu "outro" e o aluno VB respondeu "sim".

Tabela 4.12: Comentários de alunos da Turma 2 - 2013 sobre uso dos mapas conceituais como representação da média final na disciplina

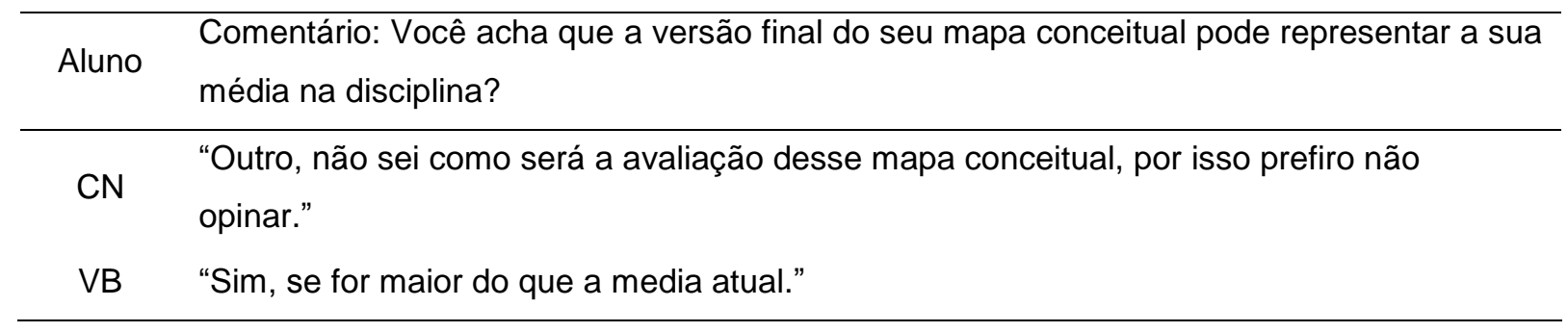

Com relação à percepção geral sobre o uso dos mapas conceituais e do software CmapTools, tem-se as seguintes análises: I) a maioria dos alunos, 61\%, não encontrou outros usos para o software CmapTools (Figura 4.38); ii) a maior parte dos alunos, 72\% considerou os mapas conceituais interessantes e úteis (Figura 4.39); e iii) conforme a Figura $4.40,67 \%$ dos alunos usariam os mapas conceituais nas demais atividades do curso de Engenharia Civil. Neste caso foram citados como exemplo: fazer resumos das aulas diárias; sumarizar textos extensos; estudar assuntos teóricos e sem cálculos matemáticos; estudar para provas e testes, conforme a Tabela 4.13. Com base nos comentários da Tabela 4.13 ficou evidente que parte dos alunos percebeu a aplicação dos mapas conceituais como ferramenta de ensino-aprendizagem e não apenas como ferramenta de avaliação.

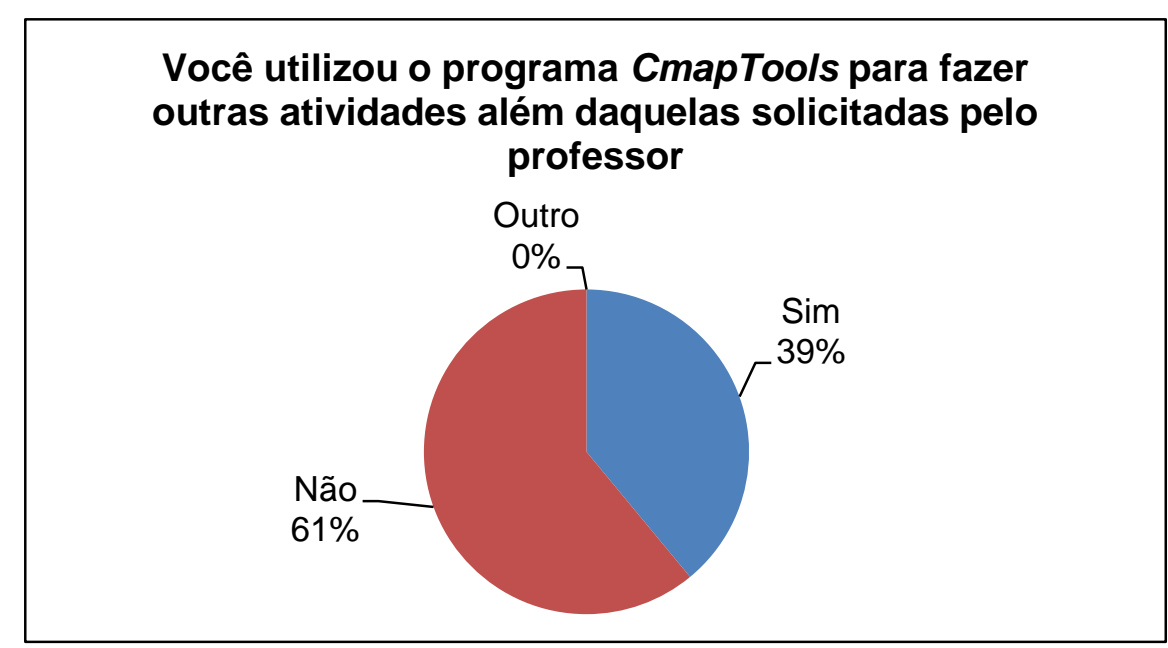

Figura 4.38: Percepção sobre o uso do CmapTools em outras atividades - Turma 2 de 2013 


\section{De uma forma geral, qual sua opinião sobre os Mapas \\ Conceituais?}

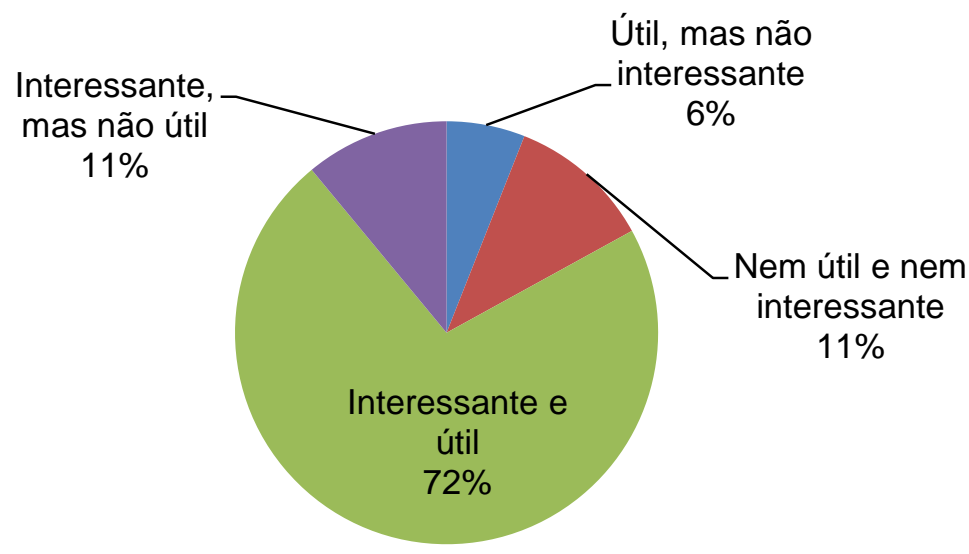

Figura 4.39: Opinião geral sobre os mapas conceituais - Turma 2 de 2013

\section{Você faria outros usos para o recurso "Mapa Conceitual" durante o cuso de Engenharia Civil?}

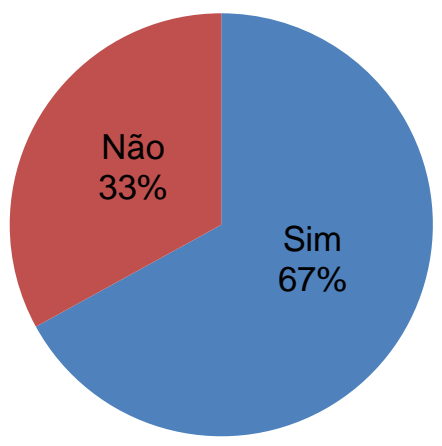

Figura 4.40: Opinião geral sobre os mapas conceituais - Turma 2 de 2013

Tabela 4.13: Comentários de alunos da Turma 2 - 2013 sobre outros usos dos mapas conceituais nas atividades do curso de Engenharia Civil.

Aluno Comentário

"Acredito que seja uma ótima maneira de estudar pra quem não consegue memorizar

TB conceitos a partir de textos compridos (longos). Pode ser utilizado em qualquer matéria mais teórica, sem muitos cálculos (exemplo: materiais de construção)."

"Fazer resumos do conhecimento adquirido em sala de aula, de modo que se possa organizar e hierarquizar os conceitos, e relacioná-los entre si." 
Desta forma, há indícios de que os mapas conceituais foram bem aceitos pela maioria dos alunos. Porém, algumas observações feitas pelos alunos em conversas de sala de aula e outros ambientes onde foram realizados os experimentos podem ser resumidos a seguir:

- Havia uma grande preocupação com relação aos critérios de avaliação dos mapas e as notas que seriam atribuídas aos mesmos (ainda que não tenha sido revelado que seriam atribuídas "notas" aos mapas);

- Alguns alunos demonstravam impaciência ou descaso durante a confecção dos mapas. Isto ficou mais evidente depois que foi revelado que os mapas não iriam compor a média final, para o caso da Turma de 2012. Para o caso das Turmas de 2013 foi acordado que poderia haver um bônus para aqueles que construíssem as três versões dos seus mapas. Sendo assim, percebeu-se mais dedicação e cuidados na confecção dos mapas. No caso das Turmas de 2013, muitas vezes os alunos solicitavam tempo extra, além dos 45 minutos previamente estipulados, para a confecção dos mapas;

- Uma boa parcela dos alunos demonstrou bastante interesse pelos mapas conceituais. Inclusive utilizaram o mapa como ferramenta de ensino-aprendizagem ou de apoio computacional para confeccionar diagramas, esquemas técnicos e árvores hierárquicas, conforme apresentado na Tabela 4.13.

- Dos 25 alunos que responderam às perguntas relativas ao uso dos mapas conceituais como ferramenta de ensino-aprendizagem e avaliação, 36\% fizeram comentários relativos à pesquisa feita por meio de questionário online. $\mathrm{Na}$ Tabela 4.14 é apresentada a quantidade de contribuições feitas por cada aluno.

Tabela 4.14: Número de comentários apresentados por aluno.

\begin{tabular}{cc}
\hline Aluno & Número de Comentários \\
\hline BF & 1 \\
CN & 1 \\
DS & 1 \\
FM & 1 \\
JB & 2 \\
TB & 4 \\
MYM & 1 \\
SN & 1 \\
VB & 1 \\
\hline
\end{tabular}




\subsubsection{Abordagem geral sobre os mapas conceituais}

De uma forma geral, a análise sobre o uso dos mapas conceituais como ferramenta de avaliação pode ser resumida da seguinte forma:

i. Os mapas permitiram observar a evolução do domínio conceitual e do domínio de relação conceitual dos alunos;

ii. É preciso gerar nos alunos algum tipo de estímulo para que eles realmente dediquem algum tempo para a confecção dos seus mapas;

iii. Foi possível estabelecer uma avaliação ampla e fidedigna entre as médias finais dos alunos na disciplina e uma avaliação quantitativa atribuída aos mapas. Esta avaliação foi feita com base nos critérios apresentados no item 3.3;

iv. Algumas mudanças nos critérios de confecção permitiram aprimorar o processo de construção dos mapas. Ao invés de sugerir 30 conceitos-chave, como feito para a Turma de 2012, no ano de 2013 foram sugeridos apenas 13 conceitos. Esta ação possibilitou aos alunos acrescentar outros conceitos. Os 13 conceitos sugeridos foram retirados do mapa conceitual construído pelo professor e também dos organizadores prévios obtidos pela confecção do primeiro mapa conceitual dos alunos. Desta forma, a construção dos mapas seria mais eficaz e poderia resultar em mais casos de aprendizagem significativa;

v. Uma parcela significativa dos alunos no ano de 2013 dedicou mais de 45 minutos para a confecção dos seus mapas. Além disso, alguns desses alunos preferiram confeccionar seus mapas fora do horário de aula, mas sob a supervisão de um monitor ou do pesquisador;

vi. Outra mudança em termos de construção dos mapas no ano de 2013, em relação ao ano de 2012, foi a confecção e entrega da última versão do mapa. No ano de 2012 todas as três versões dos mapas conceituais foram confeccionadas em horário de aula ou fora do horário de aula, mas sob a supervisão do pesquisador ou monitor do programa PAE (no laboratório informatizado). No ano de 2013, a última versão foi feita após o término das aulas e deveria ser entregue por e-mail. Houve um número menor de alunos que entregaram a última versão no ano de 2013. Porém, aqueles alunos que entregaram seus mapas até o fechamento deste trabalho pareciam estar realmente comprometidos com o seu processo de ensino-aprendizagem e avaliação. Alguns inclusive solicitaram feedback em relação à qualidade e coerência dos mapas. 


\subsection{Proposta de Regime Integrado de Estudos Especiais em Engenharia de Transportes}

A abordagem de ensino-aprendizagem introduzida, monitorada e avaliada neste estudo permitiu ampliar competências e habilidades de alunos de graduação na área de Engenharia de Transportes. Desta forma, com base nos resultados obtidos, a pouca carga horária disponível para a formação de engenheiros de transportes nos cursos de Engenharia Civil (conforme Silva Junior e Rodrigues da Silva, 2011) e estudos recentes sobre a importância dos sistemas de transportes na atualidade, a seguir é apresentada uma proposta de Regime Integrado de Estudos Especiais em Engenharia de Transportes. Por questões de formalização da proposta foram criados temas, áreas e disciplinas integradas. A finalidade desta divisão foi sistematizar a apresentação deste regime de estudos especiais.

A ideia básica de um regime de estudos especiais é que o aluno possa cursar disciplinas específicas de uma área de conhecimento da Engenharia Civil: Geotecnia; Transportes; Estruturas etc. Este regime pode ser implantado em cursos de graduação e deve ser composto por um determinado número de disciplinas relativas à área de conhecimento. $O$ aluno, ao cumprir um determinado número mínimo de créditos em disciplinas deste regime, terá direito a receber um certificado, emitido pela instituição, atestando que cursou, obteve aprovação e que, portanto, faz jus à certificação naquela área de conhecimento.

Para construir esta proposta foram combinadas as áreas de Bill et al. (2011), diversas áreas citadas em pesquisas em geral e a Tabela das Áreas de Conhecimento da CAPES. Na Tabela 4.15 são apresentadas as diversas áreas que foram usadas para gerar esta proposta de regime de estudos especiais. Em seguida as áreas propostas em cada coluna da Tabela 4.15 foram reorganizadas em temas comuns, novas áreas específicas e disciplinas integradas, conforme a Figura 4.41. Vale ressaltar que nesta figura ainda poderiam ser estabelecidas outras relações entre temas e áreas diversas e entre disciplinas integradas e áreas diversas.

A maior preocupação na proposição das áreas e das disciplinas foi com relação ao nível de integração entre as disciplinas. Não basta apenas elencar um determinado número de disciplinas e ofertá-las aos alunos. Deve existir integração entre os temas abordados e estes devem ser estudados de modo que os conhecimentos anteriores possam ser utilizados e reorganizados a cada nova disciplina cursada pelos alunos. 
Tabela 4.15: Áreas de conhecimento relativas à Engenharia de Transportes, conforme a revisão da literatura

\begin{tabular}{lll}
\hline \multicolumn{1}{c}{ Áreas de Bill et al. (1) } & Pesquisas em Geral (2) & $\begin{array}{l}\text { Tabela das Áreas de Conhecimento } \\
\text { da CAPES (3) }\end{array}$ \\
\hline - Operações de tráfego & - Acessibilidade & - Planejamento de transportes \\
- Planejamento de transportes & - Aspectos ambientais & - Planejamento e organização do \\
- Projeto geométrico & - Aspectos sociais & sistema de transporte \\
- Financiamento do transporte & - Aspectos políticos & - Economia dos transportes \\
- Economia do transporte & - Infraestrutura urbana & - Veículos e equipamentos de \\
- Segurança no trânsito & - Modos não-motorizados & controle \\
- Transporte público urbano e & - Planejamento integrado & - Vias de transporte \\
não-motorizados & - Tráfego e circulação & - Veículos de transportes \\
& urbana & - Estação de transporte \\
& - Sistemas de transporte & - Equipamentos auxiliares e \\
& urbano & controles \\
& & - Operações de transportes \\
& & - Engenharia de tráfego \\
& & - Capacidade de vias de transporte \\
& & Operação de sistemas de \\
& transporte \\
\hline
\end{tabular}

Os temas desta proposta envolvem uma série de conhecimentos relativos à Engenharia de Transportes. Estes temas são os elementos que norteiam a construção das áreas de conhecimento e também o planejamento das disciplinas integradas. As disciplinas integradas propostas possuem uma abordagem de ensino-aprendizagem que mescla aulas expositivas com aprendizagem ativa. Neste caso, a modalidade de aprendizagem ativa sugerida é a metodologia da problematização ou resolução de problemas. Desta forma, em cada disciplina os alunos podem desenvolver, por meio da metodologia da problematização, competências e habilidades para a resolução de problemas específicos de cada área proposta. Ao mesmo tempo, podem também habituar-se aos procedimentos de trabalho em equipe e às formas de avaliação da aprendizagem que dão suporte a este tipo de abordagem de ensino-aprendizagem.

Sugere-se que, ao final do regime integrado de estudos especiais, os alunos desenvolvam, conforme a metodologia da problematização, a resolução de um problema relacionado à Engenharia de Transportes. Este problema deve ser extraído de um contexto e deve, conforme a metodologia da problematização, envolver os temas e conhecimentos das disciplinas do regime de estudos especiais. A apresentação da resolução do problema pode ser no formato de um projeto de Engenharia de Transportes. 


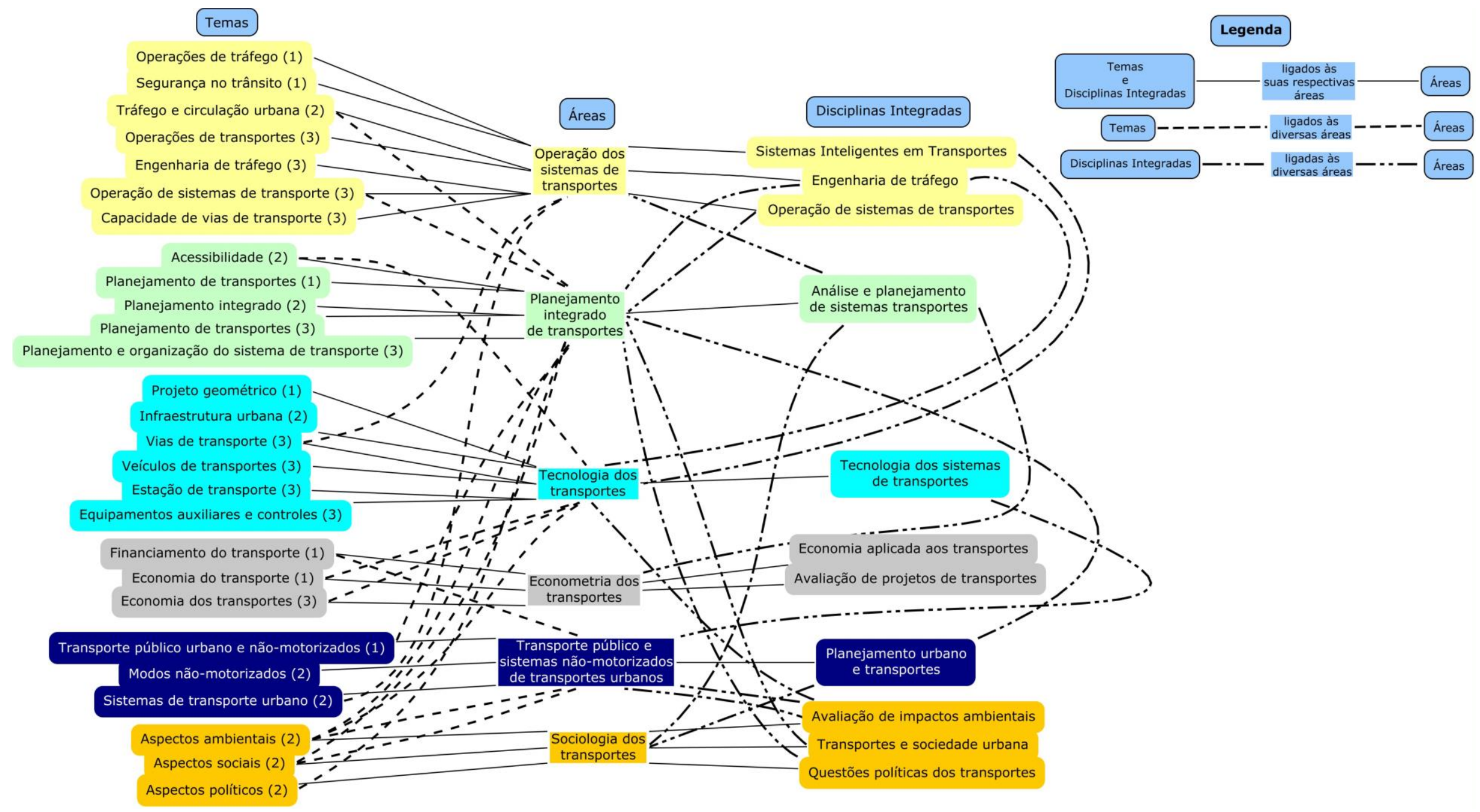

Figura 4.41: Proposta de Áreas de conhecimento e disciplinas para comporem um Regime de Estudos Especiais em Engenharia de Transportes, bem como suas relações e interrelações 
Em um estudo que abrangeu 88 alunos egressos de um curso de graduação com currículo integrado, Costa (2012) apresenta alguns pontos positivos:

- A proposta do currículo integrado visa o desenvolvimento de habilidades e competências;

- Uso de diversas técnicas e estratégias para desenvolver tarefas, tais como: operações mentais; síntese de estudos; debates; discussões em grupo; aulas práticas voltadas a um contexto real da sociedade; estudo integrado de disciplinas do básico e do profissional;

- Atividades em grupos pequenos (15 alunos), médios (30 alunos) e grandes (60 alunos);

- Estímulo a expressar conhecimentos prévios;

- Estímulo à participação em atividades de ensino, pesquisa e extensão;

- Percepção, por parte dos alunos, de que a aprendizagem ocorre de forma significativa e baseada no uso de metodologias ativas de ensino-aprendizagem;

- Organização das disciplinas de forma articulada e abrangendo diferentes áreas de conhecimento.

$\mathrm{Na}$ Figura 4.42 é apresentada, na forma de mapa conceitual, uma representação das relações que podem ser feitas com a proposta de regime de estudos especiais sugerida neste trabalho. 


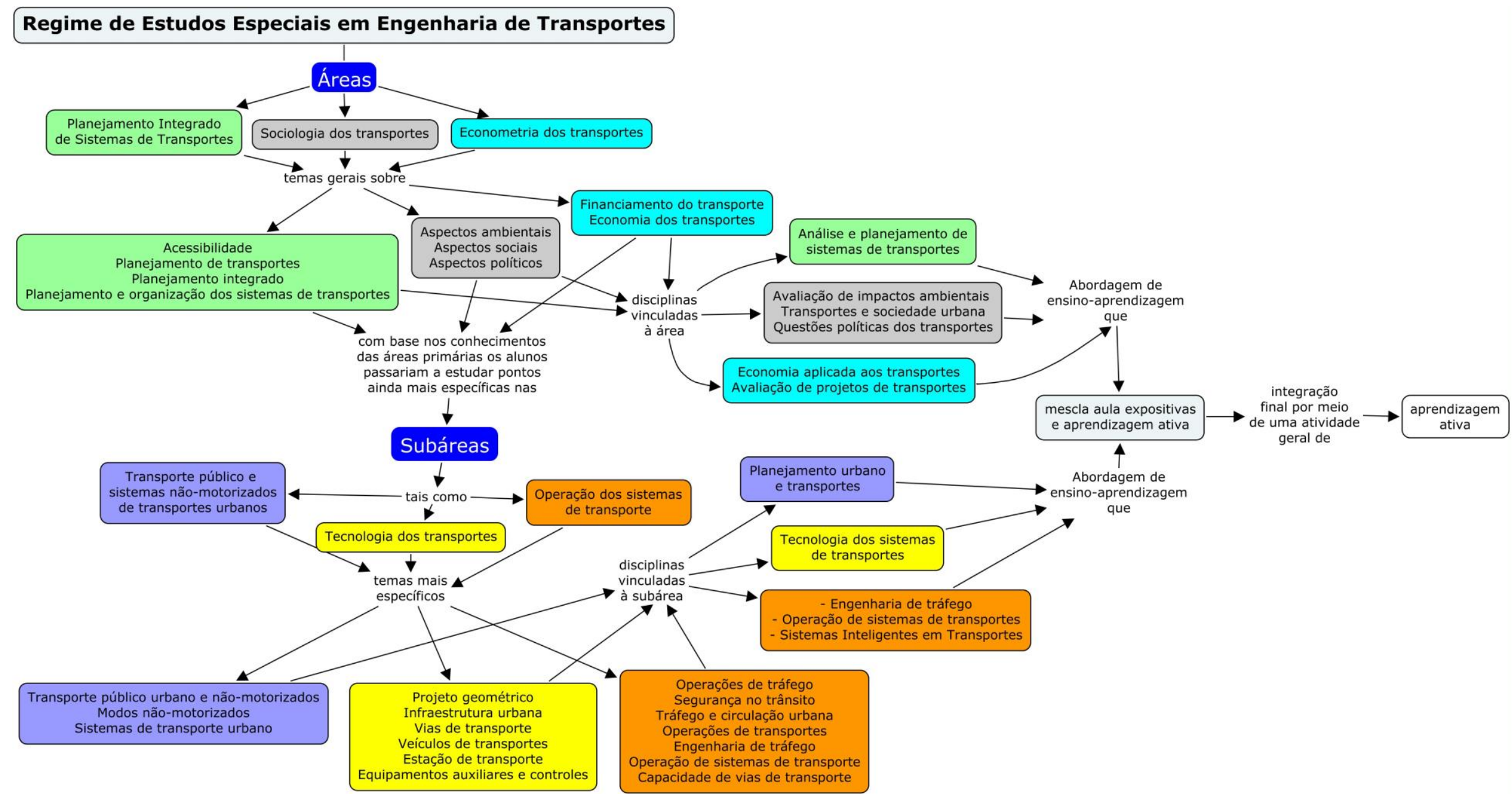

Figura 4.42: Mapa conceitual representativo do Regime de Estudos Especiais em Engenharia de Transportes 
Além dos pontos positivos apresentados anteriormente, Costa (2012) também relacionou algumas questões que precisavam ser aprimoradas, tais como:

- Melhorar a distribuição/organização das cargas horárias dos módulos ao longo das séries do curso. Desta forma, a carga horária teria melhor distribuição ao longo de todas as séries para evitar sobrecargas nos $3^{\circ}$ e $4^{\circ}$ anos do curso;

- Abordar alguns temas e conteúdos do ciclo básico de forma mais aprofundada em função da relevância para os demais conteúdos;

- Evitar troca de docentes no decorrer dos módulos ou semestres;

- Aprimorar a forma de realização das avaliações integradas para vencer as dificuldades inerentes a esta processo.

Como sugestões baseadas na percepção dos egressos, Costa (2012) destacou os seguintes itens: aumentar a carga horária de atividades práticas e manter aulas expositivas para conteúdos mais complexos.

Outra preocupação é com relação aos métodos de ensino-aprendizagem que poderão ser adotados. Deve ser dada atenção à elaboração de projetos ou atividade na forma de resolução de problema. Estes métodos devem abordar as áreas de conhecimento em questão, bem como os temas relativos às disciplinas.

Uma atividade integradora poderia ser conduzida ao final do regime na forma de uma disciplina. Teria uma abordagem bem similar àquela requerida no ambiente profissional, ou seja, a confecção e apresentação das soluções propostas pelo acadêmico deveriam estar pautadas no aspecto do ambiente de trabalho atual.

Apesar das mudanças e desafios que se apresentam na atualidade em diversos ramos da sociedade, a estrutura curricular dos cursos de engenharia no Brasil não tem acompanhado estes modificações sociais, segundo Brito (2011). O autor discute os pontos fracos dos currículos considerados tradicionais em engenharia e apresenta como alternativa um modelo de currículo integrado. O modelo proposto leva em consideração necessidades do mercado de trabalho, perfil, habilidades e competências que um profissional deveria ter para atuar em diversas áreas da engenharia. Além disso, são apresentados métodos de ensinoaprendizagem considerados mais apropriados para a engenharia.

A aplicação da abordagem testada nesta pesquisa para uma abordagem mais abrangente, tal como um regime de estudos especiais ou até mesmo um curso de graduação em engenharia implicará em resultados que podem impactar o desempenho de alunos e 
também o processo de formação. As primeiras questões que podem ser levantadas são aquelas relativas às dificuldades e barreiras apresentadas por Bonwell e Eison (1991) e discutidas no item 2.2.2 da revisão da literatura.

Sob um ponto de vista mais específico do processo de ensino-aprendizagem e do contexto educacional brasileiro podem ser também apontados os seguintes impactos:

- A legislação ou resoluções vigentes a nível nacional e das instituições de ensino que ainda são muito influenciadas pela "força" da educação tradicional;

- A dificuldade de realizar planejamento do processo de ensino-aprendizagem e avaliação de forma integrada, agora sob o ponto de vista do corpo docente (uma vez que a maioria dos professores ainda está sob a ação da "força" da educação tradicional);

- Incremento do tempo necessário para todo o processo de planejamento e operação da abordagem em um contexto mais abrangente, como por exemplo: curso de graduação em Engenharia de Transportes;

- Quantidade de alunos por turma ou relação professor-aluno em um curso de graduação;

- Perfil do aluno e seus interesses de formação.

Porém, as barreiras impostas pela "força" da educação tradicional devem ser superadas por meio de planejamento e atitude inovadora de alunos, docentes e administradores escolares. As mudanças sociais, políticas e ambientais requerem engenheiros cada vez mais preparados para resolver problemas e criar soluções de forma integrada. 


\section{CONCLUSÕES}

Este trabalho teve como objetivo introduzir, monitorar e avaliar alterações em uma abordagem pedagógica que mescla aulas expositivas e aprendizagem ativa. Tal estratégia foi concebida com o propósito de ampliar competências e habilidades, visando aprimorar a formação de alunos de graduação para a área de Engenharia de Transportes. Tanto a viabilidade como a pertinência das estratégias propostas foi avaliada, neste estudo, para o caso de uma disciplina que trata de Planejamento e Análise de Sistemas de Transportes. A seguir são apresentadas algumas considerações a respeito dos resultados obtidos na investigação, que envolveu questões relativas ao planejamento, avaliação do processo e avaliação do produto das ações de ensino-aprendizagem.

No tocante à proposta apresentada, os instrumentos de planejamento do processo de ensino-aprendizagem explorados na disciplina estudada mostraram-se promissores para a operacionalização das aulas expositivas e da atividade da metodologia da problematização. Isto pode ser evidenciado pelo bom andamento das atividades em sala de aula, dos trabalhos desenvolvidos em equipes, e pela avaliação da disciplina realizada pelos alunos. Os instrumentos não se limitaram, no entanto, ao inventário de estilos de aprendizagem e ao classificador de temperamentos mencionados na seção 3.1. Também tiveram importante papel: o emprego da tabela de conhecimentos da taxonomia dos objetivos educacionais (também mencionada na seção 3.1); os Minute Papers e a participação ativa dos alunos em tarefas de sala de aula (mencionados na seção 3.2).

De acordo com as observações feitas em sala de aula, a combinação dos estilos de aprendizagem, perfis de personalidade e taxonomia dos objetivos educacionais permitiu ao professor da disciplina traçar uma série de procedimentos que tornaram as aulas mais dinâmicas e orientadas às preferências dos alunos. Estes procedimentos (conforme a seção 3.2.1) eram aplicados durante a aula e permitiam a participação dos alunos conforme suas preferências de aprendizagem. Ao mesmo tempo, atendiam aos objetivos educacionais previstos pelo professor para cada tópico da disciplina Planejamento e Análise de Sistemas de Transportes.

Desta forma, a combinação de estratégias de planejamento que levem em consideração as expectativas dos alunos, bem como os objetivos educacionais previstos no projeto curricular do curso, pode ser importante para tornar o processo de ensino-aprendizagem mais dinâmico e voltado para o enfrentamento dos problemas atuais em engenharia. 
O uso da metodologia da problematização, juntamente com aulas expositivas tradicionais, pode ser considerado apropriado para tratar de questões relativas ao domínio de relação conceitual e procedimentos cognitivos relacionais, conforme apresentados na Taxonomia de Bloom. A etapa de avaliação, que corresponde à confecção de mapas conceituais, a realização de provas/testes e a atividade de aprendizagem ativa (na forma de resolução de problemas), foi caracterizada como válida, especificamente para esta pesquisa. $O$ uso do ambiente de aprendizagem TIDIA-Ae como ferramenta de suporte às atividades de resolução de problemas mostrou-se promissor, de acordo com as respostas dos alunos ao questionário de avaliação geral da disciplina.

Ainda com relação ao uso do ambiente de aprendizagem TIDIA-Ae, observa-se que a maioria dos alunos teve pouco contato com este ambiente online. Este aspecto pode ser apontado como motivo para uma pequena parcela de rejeição ao emprego do TIDIA-Ae como ferramenta de suporte ao ensino-aprendizagem. Além disso, pode-se evidenciar que este pouco contato por parte dos alunos é reflexo da subutilização do sistema TIDIA-Ae, fato que pode ser plenamente resolvido a partir do momento que houver maior divulgação e consequente inserção do sistema online na proposta curricular dos cursos de graduação da instituição.

Com relação ao emprego da aprendizagem ativa observou-se, com base na revisão da literatura, que a metodologia da problematização é algumas vezes confundida com a aprendizagem baseada em problemas (ou PBL, da sigla em inglês). O conhecimento desta diferença conceitual e prática possibilitou um melhor entendimento dos processos da metodologia da problematização, bem como o emprego mais eficaz dos mapas conceituais como ferramenta de avaliação em conjunto com provas e testes tradicionais.

Sobre o uso da aprendizagem ativa no ensino de Engenharia de Transportes e com base no estudo que foi desenvolvido, pode-se afirmar que a melhor opção atualmente em termos de método de ensino-aprendizagem é a metodologia da problematização. Isto porque esta metodologia pode se adaptar melhor as condições de projeto de curso, infraestrutura, perfil docente e discente vigente na maioria das escolas de engenharia no Brasil. Desta forma, o uso desta metodologia poderia ser uma alternativa viável e até mesmo um processo de transição, tanto para as instituições quanto para os demais envolvidos quando se trata de aprendizagem ativa. 
Observou-se também que o processo de aprendizagem ativa, na forma de metodologia da problematização, que foi devidamente planejado conforme a taxonomia dos objetivos educacionais de Bloom, atendeu aos objetivos educacionais previstos pelo professor, ou seja, trabalhar a dimensão dos processos cognitivos, mais especificamente as habilidades de analisar, avaliar e criar.

A conclusão principal deste estudo é, no entanto, que os mapas conceituais mostraram-se viáveis e úteis para a avaliação da aprendizagem dos alunos. Isso pode ser comprovado pela análise conduzida em relação às três versões dos mapas construídos. Foi possível observar quais tipos de domínios os alunos puderam obter e principalmente comparar as versões dos mapas e ter uma noção da evolução ao longo da disciplina. Outra questão muito importante é com relação à comparação da avaliação quantitativa dos mapas com a média final. Os resultados encontrados apontam evidências de que os mapas conceituais podem servir como outro instrumento ou parâmetro para uma avaliação mais precisa e coerente com os resultados de aprendizagem pretendidos.

Com relação à percepção dos alunos da turma de 2013 em relação ao uso dos mapas, pode-se concluir também que a maioria dos alunos considerou o uso dos mapas útil e interessante. Além disso, uma parcela significativa indicou ter usado os mapas em outras atividades e disciplinas do curso. Isto pode ser uma forte evidência de que os mapas conceituais são ferramentas que possuem potencial de uso como método de ensino e de avaliação da aprendizagem.

Outra questão que ficou evidente tanto na pesquisa sobre a percepção dos mapas quanto em comentários feitos pelos alunos, em sala de aula, era a preocupação sobre a utilização dos mapas como ferramenta de avaliação. Percebe-se que uma parcela significativa dos alunos ainda prefere avaliações em um formato mais tradicional e não se sente a vontade sob a possibilidade de que podem estar sendo avaliados por uma ferramenta que não está formalizada institucionalmente ou que pode ser algo relativamente inovador.

Uma questão também muito importante e que vale ressaltar foi o processo de análise e avaliação dos mapas. As turmas que participaram dos experimentos nos anos de 2012, 2013-1 e 2013-2, possuíam respectivamente, 30, 27 e 25 alunos. Nestas turmas, cada aluno confeccionou três versões de mapas conceituais que totalizaram, respectivamente, 90, 81 e 75 mapas. Estes mapas precisaram ser interpretados, analisados e posteriormente avaliados para fins de apresentação de resultados. Este processo geral de análise e revisão era feito de forma manual pelo professor e pelo pesquisador. Além disso, era necessário 
conversar pessoalmente com cada estudante para que ele/ela explicasse as ligações feitas entre os conceitos apresentados nos mapas. Isto demandava um tempo relativamente grande, apesar de ter sido feito com base em critérios específicos. Talvez esta seja a principal dificuldade apontada para o uso dos mapas conceituais como ferramenta de ensino-aprendizagem e avaliação do processo.

Em contrapartida, o programa computacional CmapTools possui uma ferramenta de análise automatizada que compara mapas conceituais entre si, porém esta ferramenta não estava adequada aos critérios de análise e avaliação que foram estipulados para esta pesquisa. Para adequar este processo automatizado seria preciso programar novas rotinas no código fonte do CmapTools. Por ser um software livre, isto é possível, mas não pôde ser feito durante as atividades desenvolvidas nesta pesquisa.

De um modo geral, o uso dos mapas conceituais como instrumento de avaliação do processo de ensino-aprendizagem não exclui o uso de ferramentas tradicionais de avaliação. Pelo contrário, conforme os resultados obtidos para a abordagem testada neste estudo, combinar provas e mapas conceituais como meios de avaliação pode tornar o processo mais abrangente e efetivo.

A proposta de Regime Integrado de Estudos Especiais em Engenharia de Transportes apresentada neste trabalho pode ser uma alternativa de curto e médio prazo para a formação de engenheiros de transportes. Ainda que seja apenas uma proposta, pode ser devidamente desenvolvida usando os mesmos critérios aqui apresentados. Também pode ser adaptada para uma situação específica de formação, bem como para outras áreas da engenharia. Porém, deve ser ressaltado que o mais importante nesta questão da proposta aqui apresentada é a integração entre as disciplinas que irão compor o Regime de Estudos Especiais.

Outra questão, com base nos resultados obtidos nesta pesquisa, é que este regime integrado poderá trazer melhores resultados, caso seja implementado de forma a combinar métodos de ensino tradicionais e métodos de aprendizagem ativa. Por fim, considerando os aspectos acima discutidos, caberia ainda realizar uma abordagem experimental que permitisse atestar níveis de Aprendizagem Significativa, com base em um conjunto de disciplinas de um currículo mínimo integrado. 


\section{SUGESTÕES PARA TRABALHOS FUTUROS}

Em função dos resultados evidenciados e principalmente aqueles que não puderam ser alcançados devido às limitações impostas por questões curriculares, a seguir são apresentadas algumas sugestões de pesquisa:

- Estudar o uso dos mapas conceituais como ferramenta formal de ensinoaprendizagem e avaliação em uma disciplina ou conjunto de disciplinas integradas, pois assim poder-se-ia ter uma noção mais realista do comportamento dos alunos frente a esta ferramenta;

- Aperfeiçoar os procedimentos de análise e avaliação de mapas conceituais;

- Desenvolver pacotes de rotinas de programação no código fonte do CmapTools de acordo com os critérios de análise e avaliação adotados para uma dada situação de pesquisa;

- Elaborar um experimento para estudar um Regime Integrado de Estudos Especiais em Engenharia de Transportes, de forma a empregar os procedimentos de planejamento, os métodos e técnicas de ensino-aprendizagem e os formatos de avaliação usados neste estudo;

- Utilizar técnicas de apoio à decisão que considerem a percepção dos intervenientes (alunos, professores, sociedade civil organizada, administradores escolares, etc.) para a tomada de decisão sobre avaliação da aprendizagem, conforme pesquisa já em andamento de Silva Junior e Rodrigues da Silva (2013b);

- Desenvolver estudos sobre a percepção de professores de engenharia em relação a métodos de ensino-aprendizagem;

- Desenvolver pesquisas que possam estimular as agências de fomento governamentais a investirem, por meio de chamadas públicas, em ações que favoreçam estudos e aplicações de métodos considerados inovadores ou a combinação desses métodos com aqueles considerados tradicionais. 


\section{REFERÊNCIAS BIBLIOGRÁFICAS}

ABET - Accreditation Board for Engineering and Technology (2012) Criteria for Accrediting Engineering Programs: Effective for Reviews during the 2013-2014 Accreditation Cycle. http://www.abet.org/uploadedFiles/Accreditation/Accreditation_Step_by_Step/Accreditation_ Documents/Current/2013_-_2014/eac-criteria-2013-2014.pdf. Acessadoem 04/2014.

Alvarstein, V e L. K. Johannsen (2001) Problem-based Learning Approach in Teaching Lower Level Logistics and Transportation. International Journal of Physical Distribution \& Logistic Management. v. 31, n. 7/8, p. 557-573.

Anastasiou, L. G. C (1998) Metodologia do Ensino Superior: da Prática Docente a uma Possível Teoria Pedagógica. IBPEX Editora, Curitiba.

Antunes, F. H. C. (2011) Aprendizagem Significativa no Ensino de Conceitos em Aulas de Educação Física Escolar. Tese de Doutorado. Universidade de São Paulo. São Paulo.

ASCE - American Society of Civil Engineers (2008) Civil Engineering Body of Knowledge for the 21st Century: Preparing the Civil Engineer for the Future. $2^{\text {nd }}$ Edition. American Society of Civil Engineers. Virginia, USA.

Auler, D. e W. A. Bazzo (2001) Reflexões para a Implementação do Movimento CTS no Contexto Educacional Brasileiro. Ciência \& Educação. v. 7, n.1, p.1-13.

Auler, D. (2009) O Movimento CTS: Origem, Desdobramentos e Desafios no Contexto Brasileiro. Encontro Nacional de Pesquisa em Educação em Ciências. Florianópolis.

Ausubel, D. P.; J. D. Novak; e H. Hanesian (1980) Psicologia Educacional. Editora Interamericana, Rio de Janeiro.

Bazzo, W. A. (1998) Ciência, Tecnologia e Sociedade: e o Contexto da Educação Tecnológica. EDUFSC, Florianópolis.

Berbel, N. A. N (1998) A Problematização e a Aprendizagem Baseada em Problemas: Diferentes Termos ou Diferentes Caminhos? Interface - Comunicação, Saúde, Educação. v. 2, n. 2, p. 139-154.

Bergamo, M (2010) O Uso de Metodologias Diferenciadas em Sala de Aula: Uma Experiência no Ensino Superior. Revista Interdisciplinar Eletrônica das Faculdades Unidas do Vale do Araguaia. v. 2, n. 4. Artigo acessado em 04/2013. Disponível em: http://revista.univar.edu.br/read.php?doc=downloads/metodologiasdiferenciadas.pdf.

Bill, A.; S. Beyerlein; K. Heaslip; D. S. Hurwitz.; K. L. S. Bernhardt; M. Kyte e R. K. Young (2011) Development of Knowledge Tables and Learning Outcomes for the Introductory Course in Transportation Engineering. Proceedings of the $90^{\text {th }}$ Annual Meeting of the Transportation Research Board, Washington, D.C., EUA.

Bloom, B. S.; M. D. Engelhert; E. J. Furst; W. H. Hill e D. R. Krathwohl (1972) Taxonomia de Objetivos Educacionais: Domínio Cognitivo. Globo, Porto Alegre.

Bonwell, C. e J. A. Eison (1991). Active Learning: Creating Excitement in the Classroom. ASHE-Association for the Study of Higher Education e ERICC learinghouse on Higher Education, Washington, D.C. USA.

Bound, D. J. e G. Feletti (1997) The Challenge of Problem-Based Learning. Kogan-Page, London.

Brito, W. A. (2011) Proposta de Construção de um Currículo Integrado de Engenharia. XXXIX Congresso Brasileiro de Educação em Engenharia, COBENGE, Blumenau - SC. 
Cantú, E (2005) Elementos para o Fortalecimento da Mediação Docente na Educação Tecnológica: Aplicação no Ensino-Aprendizagem de Redes de Computadores. Tese de Doutorado. Universidade Federal de Santa Catarina.

Cardoso, I. M. e R. da Silva Lima (2011). Métodos Ativos de Aprendizagem: O Uso do Aprendizado Baseado em Problemas no Ensino de Logística e Transportes. Transportes. v. 20, n. 3, p. 79-88. DOI:10.4237/transportes.v20i3.561.

Colenci-Trevelin, A. T.; A. Colenci Junior; E. Rovai e H. G Peterossi. (2008) A Relação Professor Aluno Estudada sob a Ótica dos Estilos de Aprendizagem: Uma Análise da Faculdade de Tecnologia de Taquaritinga - Fatec. Reverte. v. 6, n.6, p. 189-200.

Corrêa, R. R (2009) Avaliação Formativa: O Mapa Conceitual na Autorregulação da Aprendizagem. Dissertação de Mestrado - Universidade Estadual de Londrina.

Costa, T. V. (2012) Atuação Profissional de Enfermeiros Egressos do Currículo Integrado de uma Universidade Pública do Norte do Paraná. Dissertação de Mestrado. Universidade Estadual de Londrina.

Cury, H. N. (2000) Estilos de Aprendizagem de Alunos de Engenharia. XXVIII Congresso Brasileiro de Ensino de Engenharia, COBENGE, Ouro Preto - MG. (CD-ROM). Ouro Preto.

Darmofal, D. L., D. H. Soderholm, e D. R. Brodeur (2002) Using Concept Mapsand Concept Questions to Enhance Conceptual Understanding.Proceedings of $32^{\text {th }}$ ASEE/IEEE Frontiers en Education Conference, Boston, USA.

Escrivão Filho, E. e L. R. Camargo Ribeiro (2009) Aprendendo com PBL AprendizagemBaseada em Problemas: Relato de uma experiência em cursos de engenharia da EESC-USP. Minerva: Pesquisa e Tecnologia. v. 6, no 1, pp 23-30.

Felder, R. M. e L. K. Silverman (1988) Learning and Teaching Styles in Engineering Education. Engineering Education. v. 78, n. 7, pp. 674-681.

Felder, R. M. e B. A. Soloman (2004) Index of Learning Styles (ILS). Disponível em: www2.ncsu.edu/unity/lockers/users/f/felder/public/ILSpage.html. Acessado em abril de 2012.

Felder, R. M. e J. Spurlin (2005) Applications, Reliability and Validity of the Index of Learning Styles. International Journal of Engineering Education. v. 21, n. 1, p. 103-112.

Ferreira, A.; G. Marsden e M. Te Brömmelstroet (2013) What Curriculum for Mobility and Transport Studies? A Critical Exploration. Transport Reviews: A Transnational Transdisciplinary Journal, v. 33, n. 5, p. 501-525, DOI: 10.1080/01441647. 2013. 827266

Ferraz, A. P. C. M. e R. V. Belhot (2010) Taxonomia de Bloom: Revisão Teórica e Apresentação das Adequações do Instrumento para Definição de Objetivos Instrucionais. Revista Gestão e Produção. v. 17, n. 2, pp. 421-431.

Fini, E. H., e M. Mellat-Parast (2012) Using Project-Based Learning (PBL) to Improve Student Learning in Transportation Engineering. The Annual Meeting of the Transportation Research Board, Washington, D.C., USA.

Francis, R., e S. J. Shannon(2013) Engaging with Blended Learning to Improve Students' Learning Outcomes. European Journal of Engineering Education. v. 38, n. 4, p.359-369. DOI: 10.1080/03043797.2013.766679

Guedes, M. G; J. M. Lourenço; A. I. Filipe; L. Almeida e M. A. Moreira (2007) Bolonha: Ensino e Aprendizagem por Projecto. Centro Atlântico, Lisboa, Portugal.

Harper, B.; C. Ceccon; M. Darcy de Oliveira; R. Darcia de Oliveira (1987) Cuidado Escola! Desigualdade Domesticação e Algumas Saídas. Editora Brasiliense, 24를 Ed. São Paulo.

Hoic-Bozic, N., V. Mornar, e I. Boticki (2009) A Blended Learning Approach to Course Design and Implementation. IEEE-Transactions on Education. v. 52, n. 1, p. 19-30. 
Keirsey, D. e M. Bates (1984) Please Understand Me : Character \& Temperament Types. Prometheus Nemesis Book Company, Del Mar, CA, U.S.A.

Khisty C. J e B. K. Lall (2003) Transportation Engineering - An Introduction. $3^{\mathrm{a}}$ ed. Prentice Hall, Upper Saddle River, New Jersey, USA.

Kolb, D. A. (1984) Experimental Learning: Experience as a Source of Learning and Development . Prentice-Hall. New Jersey.

Krasilchik, M. (2008) Docência no Ensino Superior: Tensões e Mudanças. Cadernos de Pedagogia Universitária, n. 4. Universidade de São Paulo, Pró-Reitoria de Graduação, Faculdade de Educação.

Krummenauer, W. L. (2012) Mapas Conceituais como Instrumentos de Avaliação em uma Disciplina de Física no curso de Engenharia de Produção. Revista Espaço Acadêmico. v. 11, n. 131, p. 138-144.

Kuri, N. P. (2004) Tipos de Personalidade e Estilos de Aprendizagem: Proposições para o Ensino de Engenharia. Tese de Doutorado. UFSCAR - Universidade Federal de São Carlos. São Carlos.

Kyte, M, M. Dixon, A. Abdel-Rahim e S. Brown (2010) A Process for Improving the Design of transportation Curriculum Materials with Examples. Proceedings of the $89^{\text {th }}$ Annual Meeting of the Transportation Research Board (CD-ROM).

Lambros, A (2004) Problem Based Learning in Middle and High School Classrooms: A Teacher's Guide to Implementation. Corwin Press. SAGE Publications Company - USA.

Leite, L. e A. Afonso (2001) Aprendizagem Baseada na Resolução de Problemas: Características, Organização e Supervisão. Boletín das Ciencias. v. 48, p. 253-260.

Leite, L. e E. Esteves (2006) Trabalho em Grupo e Aprendizagem Baseada na Resolução de Problemas: Um Estudo com Futuros Professores de Física e Química. In Actas do Congresso PBL 2006. (CD-Rom). Lima (Peru): Universidade Pontifícia Católica del Peru.

Libâneo, J. C. (2009) Conteúdos, Formação de Competências Cognitivas e Ensino com Pesquisa: Unindo Ensino e Modos de Investigação. Cadernos de Pedagogia Universitária, n. 11. Universidade de São Paulo, Pró-Reitoria de Graduação, Faculdade de Educação.

Lopes, A. O. (1991) Aula Expositiva: Superando o Tradicional. In: VEIGA, Ilma P. A (org.). Técnicas de Ensino: Por que não? Editora Papirus, São Paulo.

Loureiro, I. M. G (2008) A Aprendizagem Baseada na Resolução de Problemas e a Formulação de Questões a partir de Contextos Problemáticos: Um estudo com Professores e Alunos de Física e Química. Dissertação de Mestrado, Universidade do Minho, Instituto de Educação e Psicologia.

Luckesi, C. C (2011) Avaliação da Aprendizagem Escolar: Estudos e Proposições. 22ª ed. Cortez Editora, São Paulo.

Machado, D. I. e R. Nardi (2008) O Emprego de Mapas Conceituais na Produção de Sistemas Hipermídia Educativos. $2^{\circ}$ Encontro Nacional de Aprendizagem Significativa. Canela: Rio Grande do Sul, v.1, p. 242-251.

Mager, R. F. Writing Learning Objectives: Beginning with the End in Mind. (1984) Disponivel em: http://www.oucom.ohiou.edu/fd/writingobjectives.pdf. Acesso em 06 de julho de 2011.

Matveev, A. V. e R. G. Milter (2010) An Implementation of Active Learning: Assessing the Effectiveness of the Team Infomercial Assignment. Innovations in Education and Teaching International. v. 47, n. 2, p. 201-213.

MEC-MINISTÉRIO DA EDUCAÇÃO - BRASIL (2002) Diretrizes Curriculares Nacionais para os Cursos de Graduação em Engenharia - Resolução CNE/CES 11/2002. Ministério da Educação - Conselho Nacional de Educação, Brasília, DF. 
Mendonça, C. A. S. e J. S. B.Carvalho. (2007) Introdução de Mapas Conceituais como Ferramenta para Auxiliar o Aprendizado em Botânica. Indivisa, Boletín de Estudios e Investigación, v. 1, p. 349-359.

Mioduser, D. e N. Betzer. (2007) The Contribution of Project-based-learning to HighAchievers' Acquisition of Technological Knowledge and Skills. International Journal of Technology and Design Education. v. 18, n. 1, p. 59-77. DOI 10.1007/s10798-006-9010-4.

Minner, D. D., A. J. Levy, e J. Century (2010) Inquiry-Based Science Instruction - What Is It and Does It Matter? Results from a Research Synthesis Years 1984 to 2002. Journal of Research in Science Teaching. v. 47, n. 4, p. 474-496.

Moreira, M. A. e E. F. S. Masini (1982) Aprendizagem Significativa: A Teoria de David Ausubel. Editora Moraes, São Paulo.

Novak, J. D (2003) The Theory Underlying Concept Maps and How to Construct them. IHMC - Institute for Human and Machine Cognition. University of West Florida, USA. Disponível em http://cmap.coginst.uwf.edu (acesso em abril de 2013).

Palmero, M. L. R (2004) La Teoría del Aprendizaje Significativo, in A. J. Cañas, J. D. Novak and F. G. García (eds), Concept Maps: Theory, Methodology, Technology - Proceedings of the First International Conference on Concept Mapping, v. 1, p. 535-544.

Pelizzari, A; M. L. Kriegl; M. P. Baron; N. T. L. Finck e S. I. Dorocinski (2002) Teoria da Aprendizagem Significativa segundo Ausubel. Revista PEC. v.2, n.1, p.37-42.

Pereira, M. A. (2005) Ensino-aprendizagem em um Contexto Dinâmico: O Caso de Planejamento de Transportes. Tese (Doutorado). Escola de Engenharia de São Carlos-USP. São Carlos.

Piemolini-Barreto, L. T. e I. G. Sandri (2011) Análise do Perfil de Aprendizagem dos Alunos de Engenharia de Alimentos da Universidade de Caxias do Sul. XXXIX Congresso Brasileiro de Educação em Engenharia, COBENGE, Blumenau - SC.

Quinn, K. A. e L. D. Albano (2008) Problem-Based Learning in Structural Engineering Education. Journal of Professional Issues in Engineering Education and Practice. v. 134, n. 4, p. 329-334.

Rodrigues da Silva, A. N. e N. P. Kuri (2011) PBL and B-Learning in Transportation Education. Proceedings of the $90^{\text {th }}$ Annual Meeting of the Transportation Research Board. Washington, D.C., EUA.

Rodrigues da Silva, A. N (2010) A Problem-Project-Practice Based Learning Approach for Transportation Planning Education. Proceedings of the PBL 2010 International Conference Problem-Based Learning and Active Learning Methodologies, São Paulo - SP (em CDROM). São Paulo: University of São Paulo/Pan-American Network of Problem-Based Learning.

Ruiz-Moreno, L; C. Songsono; S. Batista e N. Batista (2007) Mapa Conceitual: Ensaiando Critérios de Análise. Ciência e Educação. v. 13, n. 3, p. 453-463.

Seno, W. P. e R. V. Belhot (2008) Preparando a Transformação Docente: Declaração e Classificação de Objetivos Instrucionais e sua Importância para Avaliação do Aprendizado. Revista de Ensino de Engenharia. v. 27, n. 2, p. 14-22.

Serpa de Oliveira, C. A.; F. C. de Sá Barreto e R. C. Frota Bezerra (2001) Parecer $N^{\circ}$ CNE/CES 1362/2001: Diretrizes Curriculares Nacionais dos Cursos de Engenharia. CONSELHO NACIONAL DE EDUCAÇÃO - MINISTÉRIO DA EDUCAÇÃO. Diário Oficial da União. Brasília/DF.

Soares, M. A.; A. M. P. de Araujo e E. A. Leal (2012) Evidências Empíricas da Aplicação do Método Problem-Based Learning ( $P B L)$ na Disciplina de Contabilidade Intermediária do 
Curso de Ciências Contábeis. In: Camila Lima Coimbra. (Org.). Didática Para o Ensino nas Áreas de Administração e Ciências Contábeis. São Paulo: Atlas, p. 74-92.

Silva, D. M. e J. D. Oliveira Neto (2010) O Impacto dos Estilos de Aprendizagem no Ensino de Contabilidade. Contabilidade Vista \& Revista. v. 21, n. 4, p. 123-156.

Silva, V. C. (2012) Atividade de Aprendizagem em um Curso de Engenharia Elétrica: Um Estudo Baseado na Teoria da Atividade. Tese de Doutorado. Universidade Federal de Minas Gerais. Belo Horizonte.

Silva Júnior, C. A. P. e A. N. Rodrigues da Silva (2011a) Problem/Project/Practice Based Learning and Transportation Engineering Degrees. Proceedings of the International Symposium on Project Approaches in Engineering Education, Lisboa (em CD-ROM). Guimarães: Research Centre in Education (CiEd) University of Minho. v. 1. p. 237-244.

Silva Junior, C. A. P. e A. N. Rodrigues da Silva (2011b) Graduação em Engenharia de Transportes: Objetivos Instrucionais e Diretrizes Curriculares Oficiais. Anais do XXV Congresso de Pesquisa e Ensino em Transportes, ANPET, Belo Horizonte, v.1. p. 539-549.

Silva Junior, C. A. P.; H. B. Fontenele e A. N. Rodrigues da Silva (2012) Estilos de Ensino x Estilos de Aprendizagem no Processo de Ensino-Aprendizagem - Uma Aplicação em Transportes. Anais do XXVI Congresso de Pesquisa e Ensino em Transportes, ANPET, Joinville, v. 1. p. 1828-1839.

Silva Junior, C. A. P.; H. B. Fontenele e A. N. Rodrigues da Silva (2013a) Estilos de Ensino Versus Estilos de Aprendizagem no Processo de Ensino Aprendizagem: Uma Aplicação em Transportes. Transportes. v. 21, n. 2, p. 30-37.DOI: 10.4237/transportes.v21i2.686.

Silva Junior, C. A. P.; A. N. Rodrigues da Silva (2013b) Developing Learning Assessment Strategies with a MCDA-C (Multicriteria Decision Analysis - Constructivist) Approach. In: Proceedings of the Fifth International Symposium on Project Approaches in Engineering Education, Eindhoven. (em CD-ROM). Guimarães: University of Minho Guimarães. v. 1. p. ID33.1-ID33.8.

Silvestre, V; A. Schunemann; A. Ordoñez; e J. C. VAZ (2010) PBL e Agenda 21 - Problemas Socioambientais na Graduação de Gestão de Políticas Públicas para Sustentabilidade. Proceedings of the PBL 2010 International Conference - Problem-Based Learning and Active Learning Methodologies, São Paulo - SP (em CD-ROM). São Paulo: University of São Paulo/Pan-American Network of Problem-Based Learning.

Souza, N. A (2004) Avaliação da Aprendizagem e Atuação Docente. Estudos em Avaliação Educacional. n. 29, p. 149-168.

Souza, N. A. e E. Boruchovitch (2010a) Mapas Conceituais e Avaliação Formativa: Tecendo Aproximações. Educação e Pesquisa. São Paulo, v. 36, n. 3, p. 795-810.

Souza, N. A. e E. Boruchovitch (2010b) Mapas Conceituais: Estratégia de Ensino/Aprendizagem e Ferramenta Avaliativa. Educação em Revista. Belo Horizonte, v. 26, n. 3, p. 195-218.

Souza, N. A. e E. Boruchovitch (2010c) Mapa Conceitual: Seu Potencial como Instrumento Avaliativo. Pro-Posições. Campinas, v. 21, n. 3,p. 173-192.

Stange Lopes, B. J (2007) O Mapa Conceitual como Ferramenta Avaliativa. Dissertação de Mestrado - Universidade Estadual de Londrina, 2007.

Struchiner, M; A. R. Vieira e R. M. V. Ricciardi (1999) Análise do Conhecimento e das Concepções sobre Saúde Oral de Aluno de Odontologia: Avaliação por meio de Mapas Conceituais. Cadernos de Saúde Pública. v. 15, n.2, p. 55-68.

Tavares, R. e G. Luna (2007) Mapas Conceituais: Uma Ferramenta Pedagógica na Consecução do Currículo. Principia: n. 15, p. 110-116. 
Toigo, A. M.; M. A. Moreira e S. S. Cabral da Costa (2011) Mapas Conceptuales como Estrategia Potencialmente Facilitadora de la Conceptualización y del Aprendizaje Significativo em Biomecánica. Aprendizagem Significativa em Revistal Meaningfull Learning Review. v. 1, n. 2, p. 76-115.

Tonini, A. M. e D. P. Pinto (2008) A Flexibilização Curricular e a Engenharia. Anais da I Semana Nacional de Educação Profissional e Tecnológica, SENEPT, Belo Horizonte, MG. Disponível em: http://www.senept.cefetmg.br/site/Anaisllsenept/terca_terca2.html. Acessado em 30 de junho de 2011.

J Wua, Y. C.; C. C; J Lub; T. C. Lirnc e C. H; Yuana (2013) An overview of university level sustainable transportation curricula in North America and Europe. Transportation Research Part D: Transport and Environment. v. 26, p. 27-31. DOI: 10.1016/j.trd.2013.10.006.

Zhou, C.; A. Kolmos e J. D. Nielsen (2012) A Problem and Project-Based Learning (PBL) Approach to Motivate Group Creativity in Engineering Education. International Journal of Engineering Education. v. 28, n. 1, p. 3-16. 


\section{ANEXO A. INVENTÁRIO DOS ESTILOS DE APRENDIZAGEM}

\section{ÍNDICE DE ESTILOS DE APRENDIZAGEM}

(INDEX OF LEARNING STYLES - ILS)

por

\section{Richard Felder e Barbara A. Soloman}

traduzido para o português por Marcius F. Giorgetti e Nídia Pavan Kuri

Instruções: Responda a cada questão, assinalando apenas uma alternativa (a ou b). Se as duas alternativas se aplicam a você, escolha aquela que é mais frequente.

\section{Eu compreendo melhor alguma coisa depois de}
(a) experimentar
(b) refletir sobre ela

\section{Eu me considero}

(a) realista

(b) inovador(a)

3. Quando penso sobre o que fiz ontem, é mais provável que aflorem
(a) figuras
(b) palavras

\section{Eu tendo a}

(a) compreender os detalhes de um assunto, mas a estrutura geral pode ficar imprecisa

(b) compreender a estrutura geral de um assunto, mas os detalhes podem ficar imprecisos

\section{Quando estou aprendendo algum assunto novo, me ajuda}
(a) falar sobre ele
(b) refletir sobre ele

6. Se eu fosse um(a) professor(a), eu preferiria ensinar uma disciplina
(a) que trate com fatos e situações reais
(b) que trate com ideias e teorias

\section{Eu prefiro obter novas informações através de}
(a) figuras, diagramas, gráficos ou mapas
(b) instruções escritas ou informações verbais 


\section{Quando eu compreendo}

(a) todas as partes, consigo entender o todo

(b) o todo, consigo ver como as partes se encaixam

9. Em um grupo de estudo, trabalhando um material difícil, eu provavelmente

(a) tomo a iniciativa e contribuo com ideias

(b) assumo uma posição discreta e escuto

10. Acho mais fácil

(a) aprender fatos

(b) aprender conceitos

11. Em um livro com uma porção de figuras e desenhos, eu provavelmente

(a) observo as figuras e desenhos cuidadosamente

(b) atento para o texto escrito

12. Quando resolvo problemas de matemática, eu

(a) usualmente trabalho de maneira a resolver uma etapa de cada vez

(b) frequentemente antevejo as soluções, mas tenho que me esforçar muito para conceber as etapas para chegar a elas

13. Nas disciplinas que cursei eu

(a) em geral fiz amizade com muitos dos colegas

(b) raramente fiz amizade com muitos dos colegas

14. Em literatura de não ficção, eu prefiro

(a) algo que me ensine fatos novos ou me indique como fazer alguma coisa

(b) algo que me apresente novas ideias para pensar

\section{Eu gosto de professores}

(a) que colocam uma porção de diagramas no quadro

(b) que gastam bastante tempo explicando

16. Quando estou analisando uma estória ou novela eu

(a) penso nos incidentes e tento colocá-los junto para identificar os temas

(b) tenho consciência dos temas quando termino a leitura e então tenho que voltar atrás para encontrar os incidentes que os confirmem 
17. Quando inicio a resolução de um problema para casa, normalmente eu

(a) começo a trabalhar imediatamente na solução

(b) primeiro tento compreender completamente o problema

18. Prefiro a ideia do

(a) certo

(b) teórico

19. Relembro melhor

(a) o que vejo

(b) o que ouço

20. É mais importante para mim que o professor

(a) apresente a matéria em etapas sequenciais claras

(b) apresente um quadro geral e relacione a matéria com outros assuntos

21. Eu prefiro estudar

(a) em grupo

(b) sozinho(a)

22. Eu costumo ser considerado(a)

(a) cuidadoso(a) $\mathrm{cm}$ os detalhes do meu trabalho

(b) criativo(a) na maneira de realizar meu trabalho

23. Quando busco uma orientação para chegar a um lugar desconhecido, eu prefiro

(a) um mapa

(b) instruções por escrito

24. Eu aprendo

(a) num ritmo bastante regular. Se estudar pesado, eu "chego lá"

(b) em saltos. Fico totalmente confuso(a) por algum tempo, e então, repentinamente eutenho um "estalo"

25. Eu prefiro primeiro

(a) experimentar as coisas

(b) pensar sobre como é que eu vou fazer

26. Quando estou lendo como lazer, eu prefiro escritores que

(a) explicitem claramente o que querem dizer

(b) dizem as coisas de maneira criativa, interessante 
27. Quando vejo um diagrama ou esquema em uma aula, relembro mais facilmente

(a) a figura

(b) o que o professor disse a respeito dela

28. Quando considero um conjunto de informações, provavelmente eu

(a) presto mais atenção nos detalhes e não percebo o quadro geral

(b) procuro compreender o quadro geral antes de atentar para os detalhes

29. Relembro mais facilmente

(a) algo que fiz

(b) algo sobre o que pensei bastante

30. Quando tenho uma tarefa para executar, eu prefiro

(a) dominar uma maneira para execução da tarefa

(b) encontrar novas maneiras para execução da tarefa

31. Quando alguém está me mostrando dados, eu prefiro

(a) diagramas ou gráficos

(b) texto sumarizando os resultados

32. Quando escrevo um texto, eu prefiro trabalhar (pensar a respeito ou escrever)

(a) a parte inicial do texto e avançar ordenadamente

(b) diferentes partes do texto e ordená-las depois

33. Quando tenho que trabalhar em um projeto em grupo, eu prefiro que se faça primeiro

(a) um debate (brainstorming) em grupo, onde todos contribuem com ideias

(b) um brainstorming individual, seguido de reunião do grupo para comparar as ideias

34. Considero um elogio chamar alguém de

(a) sensível

(b) imaginativo

35. Das pessoas que conheço em uma festa, provavelmente eu me recordo melhor

(a) de suas aparências

(b) do que elas disseram sobre si mesmas

36. Quando estou aprendendo um assunto novo, eu prefiro

(a) concentrar-me no assunto, aprendendo o máximo possível

(b) tentar estabelecer conexões entre o assunto e outros com ele relacionados 
37. Mais provavelmente sou considerado(a)
(a) expansivo(a)
(b) reservado(a)

38. Prefiro disciplinas que enfatizam

(a) material concreto (fatos, dados)

(b) material abstrato (conceitos, teorias)

39. Para entretenimento, eu prefiro

(a) assistir televisão

(b) ler um livro

40. Alguns professores iniciam suas preleções com um resumo do que irão cobrir. Tais resumos são
(a) de alguma utilidade para mim
(b) muito úteis para mim

41. A ideia de fazer o trabalho de casa em grupo, com a mesma nota para todos do grupo,
(a) agrada-me
(b) não me agrada

\section{Quando estou fazendo cálculos longos}

(a) tendo a repetir todos os passos e conferir meu trabalho cuidadosamente

(b) acho cansativo conferir meu trabalho e tenho que me esforçar para fazê-lo

43. Tendo a descrever os lugares onde estive

(a) com facilidade e com bom detalhamento

(b) com dificuldade e sem detalhamento

44. Quando estou resolvendo problemas em grupo, mais provavelmente eu

(a) penso nas etapas do processo de solução

(b) penso nas possíveis consequências, ou sobre as aplicações da solução para uma ampla faixa de áreas 


\section{ANEXO B. INVENTÁRIO CLASSIFICADOR DE TEMPERAMENTOS}

\section{CLASSIFICADOR DE TEMPERAMENTOS DE KEIRSEY (KEIRSEY TEMPERAMENT SORTER) \\ por \\ David Keirsey}

Traduzido e adaptado por Nídia Pavan Kuri e Marcius F. Giorgetti. Versão atualizada em 11/11/97.

Copyrighted (C) 1997 David Keirsey

Instruções: Responda a cada questão, assinalando uma das alternativas (a ou b). Preencha depois o quadro de respostas anexo.

\section{Numa festa você}

(a) interage com muitos, incluindo estranhos

(b) interage com poucos, seus conhecidos

\section{Você se considera mais}
(a) realista do que especulativo
(b) especulativo do que realista

3. É muito pior
(a) ter a "cabeça nas nuvens", ser sonhador
(b) ser escravo da rotina

\section{Você é mais impressionado(a) por}
(a) princípios
(b) emoções

5. Você é mais atraído(a) pelo
(a) convincente
(b) comovente

\section{Você prefere trabalhar}
(a) com prazos de entrega
(b) sem amarrações

\section{Você tende a escolher}

(a) cuidadosamente

(b) impulsivamente

8. Nas festas você geralmente

(a) permanece até tarde, com energia crescente

(b) retira-se mais cedo, com energia decrescente

9. Você se sente mais atraído(a) por
(a) pessoas sensatas
(b) pessoas criativas

10. Você se interessa mais pelo
(a) real
(b) possível

11. Ao julgar os outros, você se inclina mais para
(a) as leis do que para as circunstâncias
(b) as circunstâncias do que para as leis

12. Ao tratar com outras pessoas, você tende a ser mais

(a) objetivo(a) 
(b) pessoal

13. Você é mais

(a) pontual

(b) descompromissado(a)

14. Incomoda-Ihe mais ter as coisas

(a) inacabadas

(b) concluídas

15. No seu grupo social você em geral

(a) está a par do que acontece comos outros

(b) está por fora das novidades

16. Ao realizar as tarefas de rotina, você prefere fazê-las

(a) da maneira usual
(b) da sua própria maneira

\section{Os escritores deveriam}

(a) dizer as coisas com clareza

(b) expressar as idéias com o uso de analogias

18. Você é mais atraído(a)

(a) pela consistência das ideias

(b) pelas relações humanas harmoniosas

19. Você se sente mais confortável fazendo julgamentos baseados
(a) na lógica
(b) em valores pessoais

20. Você prefere as coisas
(a) negociadas e decididas
(b) não negociadas e indefinidas

\section{Você se definiria como mais}

(a) sério(a) e firme

(b) condescendente

\section{Ao telefonar você}

(a) está seguro(a) de que dirá tudo oque precisa

(b) ensaia de antemão o que irá dizer

\section{Os fatos}

(a) "falam por si mesmos"

(b) ilustram princípios

24. Os visionários $\mathrm{o}(\mathrm{a})$
(a) aborrecem
(b) fascinam

25. Você é mais frequentemente uma pessoa
(a) calculista
(b) acolhedora

26. É pior ser
(a) injusto(a)
(b) impiedoso(a)

27. Usualmente, deve-se permitir que as coisas aconteçam
(a) por seleção e escolha cuidadosa
(b) fortuitamente e ao acaso

28. Você se sente melhor
(a) depois de ter comprado, adquirido
(b) tendo a opção de comprar

29. Na companhia de outras pessoas, você
(a) inicia a conversação
(b) espera ser abordado(a)

30. O senso comum é
(a) raramente questionável
(b) frequentemente questionável 
31. Com frequência, as crianças

(a) não se fazem úteis o suficiente

(b) não exercitam suficientemente a imaginação

32. Ao tomar decisões, você se sente mais confortável seguindo
(a) as normas
(b) a intuição

\section{Você se considera mais}
(a) firme do que gentil
(b) gentil do que firme

\section{Você considera mais admirável a} habilidade
(a) para se organizar e ser metódico(a)
(b) para se adaptar e ser maleável

\section{Você valoriza mais o}

(a) fechado, definido

(b) aberto, com opções

\section{Uma interação nova e pouco rotineira} com outras pessoas
(a) o(a) estimula e revigora
(b) consome suas reservas de energia

37. Você é mais frequentemente,
(a) uma pessoa do tipo prático
(b) uma pessoa do tipo fantasioso

38. Você tem uma maior propensão a ver

(a) como as outras pessoas são úteis

(b) como os outros veem

\section{9. É mais satisfatório}

(a) discutir um assunto a fundo

(b) chegar a um acordo sobre um assunto
40. O que mais comanda você é
(a) a sua cabeça
(b) o seu coração

41. Você se sente mais à vontade comum trabalho
(a) que siga um acordo pré-estabelecido
(b) que se desenvolva sem um plano estabelecido

\section{Você tende a buscar}
(a) o sistemático
(b) o imprevisto

\section{Você prefere}

(a) muitos amigos com contatos superficiais

(b) poucos amigos com contatos intensos

\section{Você se deixa guiar mais pelos}
(a) fatos
(b) princípios

45. Você se interessa mais por
(a) produção e distribuição
(b) projeto e pesquisa
46. É mais elogioso ser considerado(a)
(a) uma pessoa muito lógica
(b) uma pessoa muito sentimental

47. Você se autovaloriza mais por ser
(a) decidido(a), firme
(b) dedicado(a), devotado(a)

48. Com mais frequência, você prefere

(a) uma afirmação final e inalterável

(b) uma afirmação preliminar e provisória 
49. Você se sente mais confortável

(a) depois de tomar uma decisão

(b) antes de tomar uma decisão

50. Com ou para pessoas que não conhece você

(a) conversa longamente e com facilidade

(b) tem pouco a dizer

51. Você confia mais em

(a) sua experiência

(b) sua intuição

52. Você se considera

(a) mais prático(a) do que criativo(a)

(b) mais criativo(a) do que prático(a)

53. Você aprecia mais em outra pessoa

(a) a clareza do raciocínio

(b) a força dos sentimentos

54. Você está mais inclinado(a) a ser

(a) justo(a), imparcial

(b) compreensivo(a)

55. Na maioria das vezes, é preferível

(a) ter certeza de que esteja tudo acertado

(b) deixar que as coisas simplesmente aconteçam

56. Nos relacionamentos, a maior parte das coisas deveria ser
(a) renegociáveis
(b) casuais e circunstanciais

\section{Quando o telefone toca você}

(a) se apressa para atender primeiro

(b) espera que alguém atenda
58. Você aprecia mais em si mesmo(a)
(a) o forte senso de realidade
(b) a imaginação viva

59. Você se sente mais atraído(a)
(a) pelos fundamentos
(b) pelas implicações

60. Parece-Ihe pior ser muito
(a) apaixonado(a), veemente
(b) objetivo(a)

61. Você se vê, basicamente, como
(a) cabeça-dura
(b) coração-mole

62. Atrai-Ihe mais uma situação
(a) estruturada e programada
(b) não estruturada e imprevista

63. Você se considera uma pessoa mais
(a) rotineira do que original
(b) original do que rotineira

64. Você tende a ser uma pessoa
(a) de fácil aproximação
(b) algo reservada

65. Você prefere textos
(a) mais literais
(b) mais figurativos e simbólicos

66. É mais difícil para você
(a) identificar-se com os outros
(b) utilizar-se dos outros

67. Você prefere possuir
(a) a clareza da razão
(b) a força da compaixão 
68. É maior defeito

(a) não saber discernir

(b) ser crítico

69. Você prefere os acontecimentos

(a) planejados
(b) imprevistos

70. Você se considera uma pessoa mais

(a) ponderada e cuidadosa do que espontânea

(b) espontânea do que cuidadosa e ponderada 


\section{ANEXO C. QUESTIONÁRIO ONLINE PARA OBTER A PERCEPÇÃO DOS ALUNOS EM RELAÇÃO À DISCIPLINA}

1. Você se sentiu à vontade em interagir com os colegas para o desenvolvimento das atividades extraclasse (inclusive online)?
(a) Todo o tempo
(b) Às vezes
(c) Quase nunca

2. Considero mais fácil aprender os assuntos relacionados ao tema da disciplina de modo tradicional (ou seja, sem as atividades extraclasses).
(a) Concordo totalmente
(b) Concordo
(c) Neutro
(d) Discordo
(e) Discordo totalmente

3. Você já havia acessado o Tidia-Ae antes?
(a) Poucas vezes
(b) Algumas vezes
(c) Muitas vezes
(d) Nunca

4. Como você avalia o ambiente de ensino Tidia-Ae?
(a) Excelente
(b) Bom
(c) Regular
(d) Fraco
(e) Muito fraco

5. Como você avalia o seu aprendizado?
(a) Melhor do que o esperado em uma disciplina presencial
(b) Semelhante ao esperado em uma disciplina presencial
(c) Pior do que o esperado em uma disciplina presencial

6. O nível de exigência das atividades extraclasse foi:
(a) Maior que as de uma disciplina convencional
(b) Igual ao das de uma disciplina convencional
(c) Menor do que as de uma disciplina convencional 
7. Você faria outra disciplina nesse formato, ou seja, com uma combinação de atividades em sala de aula e atividades extraclasse, se a USP oferecesse?
(a) $\operatorname{Sim}$
(b) Não

8. Como você avalia o seu desempenho no projeto?
(a) Excelente
(b) Bom
(c) Regular
(d) Fraco
(e) Muito fraco

9. Qual dos meios de interação providos foi o seu favorito?
(a) Fórum
(b) Contato pessoal individual
(c) Atividade em grupo
(d) E-mail
(e) Outro (especifique)

10. 0 que você achou da atividade de projeto?
(a) Excelente
(b) Bom
(c) Regular
(d) Ruim
(e) Muito ruim

11. Como você avalia o conteúdo da disciplina?
(a) Útil, mas não interessante
(b) Nem Interessante e nem útil
(c) Interessante e útil
(d) Interessante, mas não útil

12. Qual é a sua avaliação global para essa disciplina?
(a) Muito boa
(b) Boa
(c) Regular
(d) Fraca
(e) Muito fraca 
13. Como você classifica seu aproveitamento na disciplina?
(a) Excelente
(b) Bom
(c) Regular
(d) Fraco
(e) Muito fraco

14. Qual (ou quais) das atividades abaixo contribuiu de forma mais efetiva para o aprendizado dos conteúdos?
(a) Exercícios em aula
(b) Fórum
(c) Atividades em grupo
(d) Provas
(e) Testes
(f) Outro (especifique)

15. As tarefas dessa disciplina tomaram mais tempo do que as tarefas de outras disciplinas.
(a) Concordo totalmente
(b) Concordo
(c) Neutro
(d) Discordo
(e) Discordo totalmente

16. O que você achou da utilização do Tidia-Ae na disciplina?
(a) Muito bom
(b) Bom
(c) Regular
(d) Ruim
(e) Muito ruim

17. Houve coerência entre o conteúdo ministrado e o exigido nas atividades realizadas extraclasses.
(a) Concordo totalmente
(b) Concordo
(c) Neutro
(d) Discordo
(e) Discordo totalmente

18. A proposta da disciplina, com atividades em sala de aula e atividades extraclasse (inclusive on-line), foi: 

(a) Muito boa
(b) Boa
(c) Adequada
(d) Regular
(e) Ruim

19. O professor estimulou a formação do espírito crítico.
(a) Concordo totalmente
(b) Concordo
(c) Neutro
(d) Discordo
(e) Discordo totalmente

20. A navegação pelas páginas do Tidia-Ae foi:
(a) Simples, consegui me orientar bem desde o início
(b) Adequada, porém levei um tempo para compreendê-la
(c) Um pouco complicada e levei um bom tempo para compreendê-la
(d) Muito complicada e fiquei muito confuso até o final do curso

21. Você teve dificuldades para confeccionar seus Mapas Conceituais?
(a) $\operatorname{Sim}$
(b) Não
(c) Outro

22. Em termos de quantidade, os 13 conceitos sugeridos foram suficientes.
(a) Concordo totalmente
(b) Concordo
(c) Neutro
(d) Discordo
(e) Discordo totalmente

23. Você utilizou o programa CmapTools para fazer outras atividades além daquelas solicitadas pelo docente?
(a) $\operatorname{Sim}$
(b) Não
(c) Outro

24. De uma forma geral, qual sua opinião sobre os Mapas Conceituais?
(a) Útil, mas não interessante
(b) Nem Interessante e nem útil 

(c) Interessante e útil
(d) Interessante, mas não útil

25. Você faria uma disciplina em que o único meio de avaliação do aprendizado fosse a confecção de Mapas Conceituais?
(a) $\operatorname{Sim}$
(b) Não

26. O tempo de 45 minutos foi suficiente para a confecção de cada versão dos Mapas Conceituais.
(a) Concordo totalmente
(b) Concordo
(c) Neutro
(d) Discordo
(e) Discordo totalmente

27. Você acha que a versão final do seu Mapa Conceitual pode representar a sua média na disciplina?
(a) $\operatorname{Sim}$
(b) Não
(c) Outro

28. O que você achou mais difícil na confecção dos Mapas Conceituais:
(a) Hierarquizar os conceitos (distribuir os conceitos dos mais gerais para os mais específicos)
(b) Fazer ligações coerentes entre os conceitos
(c) Encontrar palavras ou frases que ligam os conceitos de forma adequada
(d) Fazer ligações pouco perceptíveis entre os conceitos, porém coerentes
(e) Não tive nenhuma dificuldade para fazer os Mapas Conceituais
(f) Outra

29. Você faria outros usos para o recurso "Mapa Conceitual" durante o curso de Engenharia Civil?
(a) $\operatorname{Sim}$
(b) Não
(c) Se sim, cite pelo menos um exemplo de emprego 


\section{ANEXO D. INSTRUMENTO PARA OBTER O ESTILO DAS AULAS}
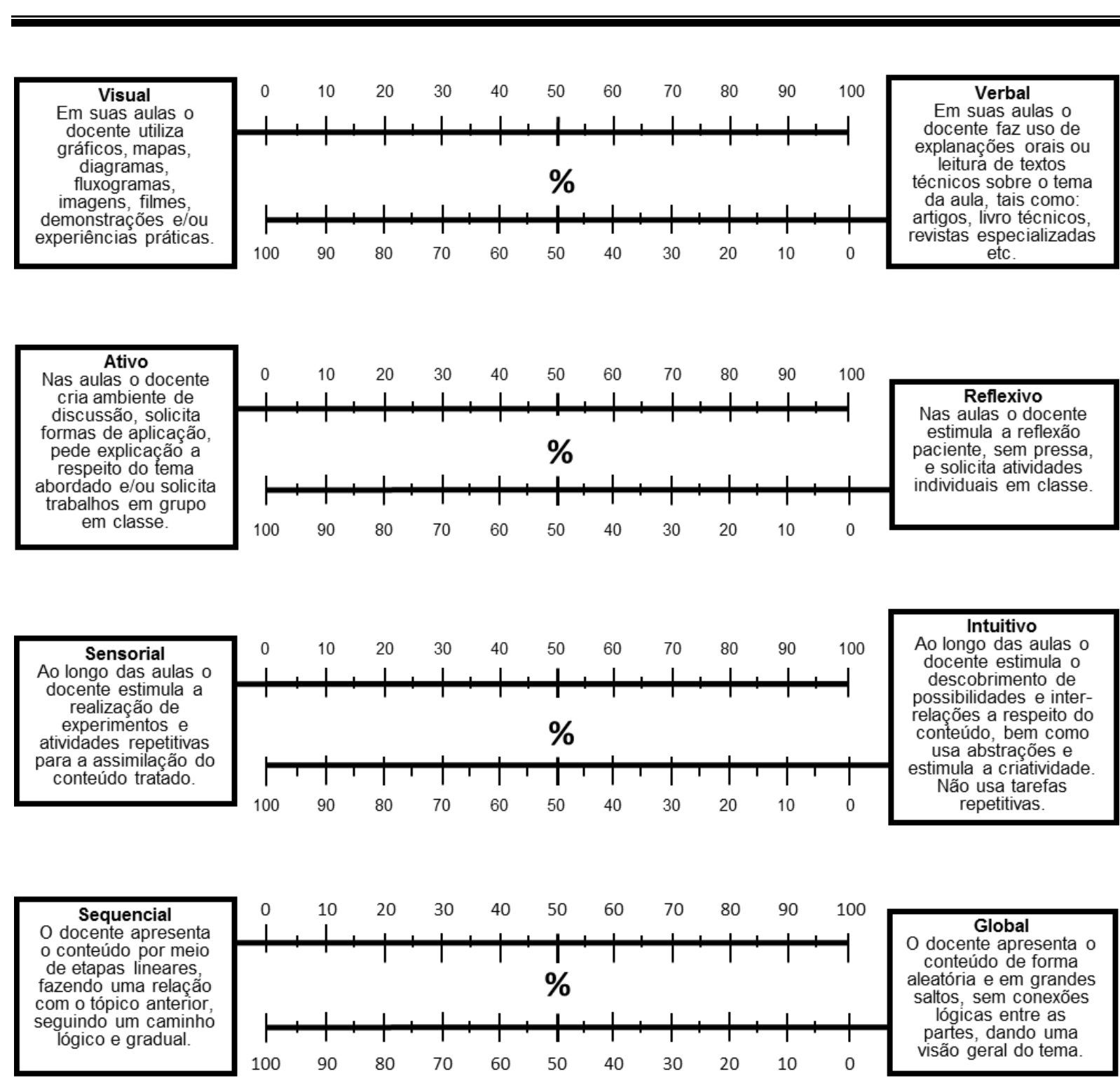
Global
docente apresenta conteúdo de forma aleatória e em grandes saltos, sem conexões lógicas entre as partes, dando uma visão geral do tema

Fonte: Silva Junior, C. A. P.; H. B. Fontenele; e A. N. Rodrigues da Silva (2013) Estilos de Ensino vs. Estilos de Aprendizagem no Processo de Ensino-aprendizagem: Uma Aplicação em Transportes. Transportes (Rio de Janeiro), v. 21, p. 30-37. 


\section{ANEXO E. TURMAS QUE PARTICIPARAM DOS EXPERIMENTOS}

\begin{tabular}{|c|c|c|c|c|c|}
\hline \multicolumn{2}{|c|}{$\begin{array}{c}\text { Alunos - Turma de } 2012 \\
\text { Docente A }\end{array}$} & \multicolumn{2}{|c|}{$\begin{array}{c}\text { Alunos - Turma } 1 \text { de } 2013 \\
\text { Docente B }\end{array}$} & \multicolumn{2}{|c|}{$\begin{array}{c}\text { Alunos - Turma } 2 \text { de } 2013 \\
\text { Docente A }\end{array}$} \\
\hline Sexo & $\begin{array}{c}\text { Sigla dos Nomes dos } \\
\text { Alunos }\end{array}$ & Sexo & $\begin{array}{c}\text { Sigla dos Nomes dos } \\
\text { Alunos }\end{array}$ & Sexo & $\begin{array}{c}\text { Sigla dos Nomes dos } \\
\text { Alunos }\end{array}$ \\
\hline $\mathrm{M}$ & $A G$ & $\mathrm{M}$ & AM & $\mathrm{F}$ & $\mathrm{AF}$ \\
\hline M & AW & $\mathrm{F}$ & $\mathrm{BR}$ & M & $A C$ \\
\hline $\mathrm{M}$ & $\mathrm{AH}$ & M & DA & $\mathrm{F}$ & $\mathrm{BF}$ \\
\hline M & BS & M & DT & $\mathrm{F}$ & $\mathrm{CB}$ \\
\hline $\mathrm{M}$ & $\mathrm{CP}$ & $\mathrm{F}$ & FS & $\mathrm{F}$ & $\mathrm{CN}$ \\
\hline $\mathrm{F}$ & DCS & M & FB & $\mathrm{F}$ & $\mathrm{CR}$ \\
\hline M & $\mathrm{DC}$ & $\mathrm{F}$ & GMM & M & DS \\
\hline M & FC & M & GR & M & EM \\
\hline $\mathrm{F}$ & FA & $\mathrm{F}$ & IS & M & $\mathrm{EF}$ \\
\hline $\mathrm{F}$ & FMT & $\mathrm{F}$ & JBA & M & FM \\
\hline M & FT & M & $\mathrm{JL}$ & $\mathrm{F}$ & IZ \\
\hline M & GPM & $\mathrm{F}$ & $\mathrm{JM}$ & M & $J P$ \\
\hline $\mathrm{F}$ & JA & M & KC & $\mathrm{F}$ & $\mathrm{JB}$ \\
\hline M & $\mathrm{JH}$ & $\mathrm{F}$ & $\mathbf{L R}^{\star}$ & M & LM \\
\hline $\mathrm{F}$ & JF & M & $\mathrm{LH}^{*}$ & M & LMP \\
\hline $\mathrm{M}$ & $\mathrm{JC}$ & $M$ & MC & $M$ & LS \\
\hline $\mathrm{F}$ & LC & $M$ & MM & $\mathrm{F}$ & MYM \\
\hline $\mathrm{F}$ & $\mathrm{LR}^{\star}$ & $M$ & $\mathrm{MZ}$ & $\mathrm{F}$ & MT \\
\hline M & LG & M & MJ & M & $\mathrm{RL}$ \\
\hline M & $\mathrm{LH}^{*}$ & M & MR & $\mathrm{F}$ & SN \\
\hline $\mathrm{M}$ & MO & $M$ & $\mathrm{ML}$ & $\mathrm{F}$ & $\mathrm{TL}$ \\
\hline $\mathrm{M}$ & MAM & $\mathrm{F}$ & $\mathrm{PL}$ & $\mathrm{F}$ & TB \\
\hline$M$ & $\mathrm{MB}$ & $M$ & RA & $M$ & TR \\
\hline $\mathrm{F}$ & ME & $F$ & RM & $M$ & VB \\
\hline$M$ & RJ & $F$ & $\mathrm{RC}$ & M & VS \\
\hline$M$ & $\mathrm{RP}$ & $M$ & $R G$ & & \\
\hline$M$ & RK & $M$ & RT & & \\
\hline$M$ & VR & & & & \\
\hline$M$ & WS & & & & \\
\hline$F$ & $\mathrm{YH}$ & & & & \\
\hline
\end{tabular}

\section{Legenda}

\section{${ }^{*}$ Alunos repetentes}

\begin{tabular}{|l|}
\hline F - Feminino \\
\hline M - Masculino \\
\hline Mapas no Anexo F - Turma 2012 \\
\hline Mapas no Anexo F - Turma 1 de 2013 \\
\hline Mapas no Anexo F - Turma 2 de 2013 \\
\hline
\end{tabular}




\section{ANEXO F. MAPAS CONCEITUAIS}

\begin{tabular}{|c|c|c|}
\hline Alunos - Turma 2012 & Média Final Disciplina & Média Mapa Conceitual \\
\hline FT & 9,8 & 9,5 \\
\hline RP & 4,6 & 7,5 \\
\hline VR & 6,4 & 6,0 \\
\hline WS & 7,6 & 7,5 \\
\hline
\end{tabular}

\begin{tabular}{|c|c|c|}
\hline Alunos - Turma 1 de 2013 & Média Final Disciplina & Média Mapa Conceitual \\
\hline GMM & 8,6 & 8,5 \\
\hline PL & 5,4 & 9,0 \\
\hline $\mathrm{LH}^{*}$ & 6,2 & 6,5 \\
$\mathrm{MC}$ & 9,0 & 6,0 \\
\hline
\end{tabular}

\begin{tabular}{|c|c|c|}
\hline Alunos - Turma 2 de 2013 & Média Final Disciplina & Média Mapa Conceitual \\
\hline CR & 9,5 & 9,5 \\
\hline MYM & 7,3 & 8,5 \\
\hline VB & 6,6 & 6,0 \\
\hline TL & 9,2 & 7,0 \\
\hline
\end{tabular}

\section{*Aluno repetente}




\section{Mapas - Turma de 2012}

\section{FT - Versões 1, 2 e 3}

Versão 1

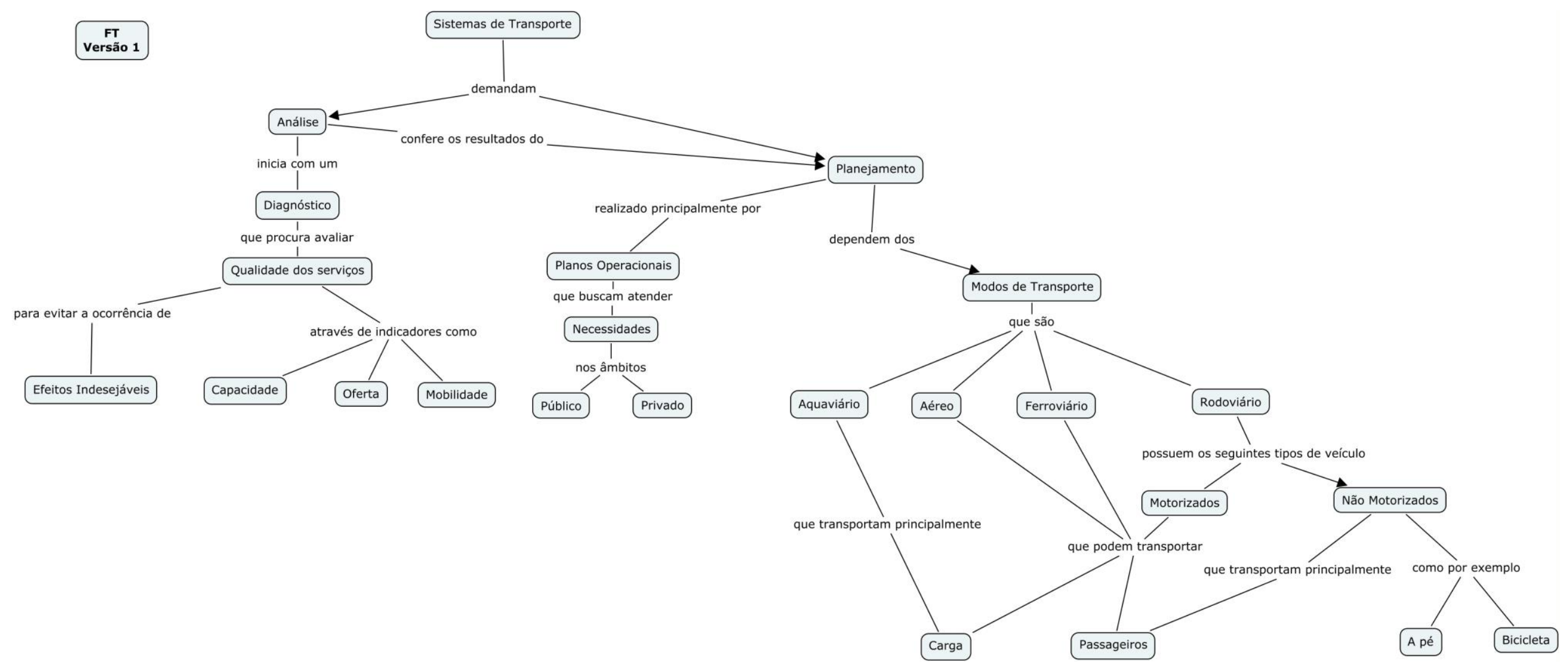


Versão 2

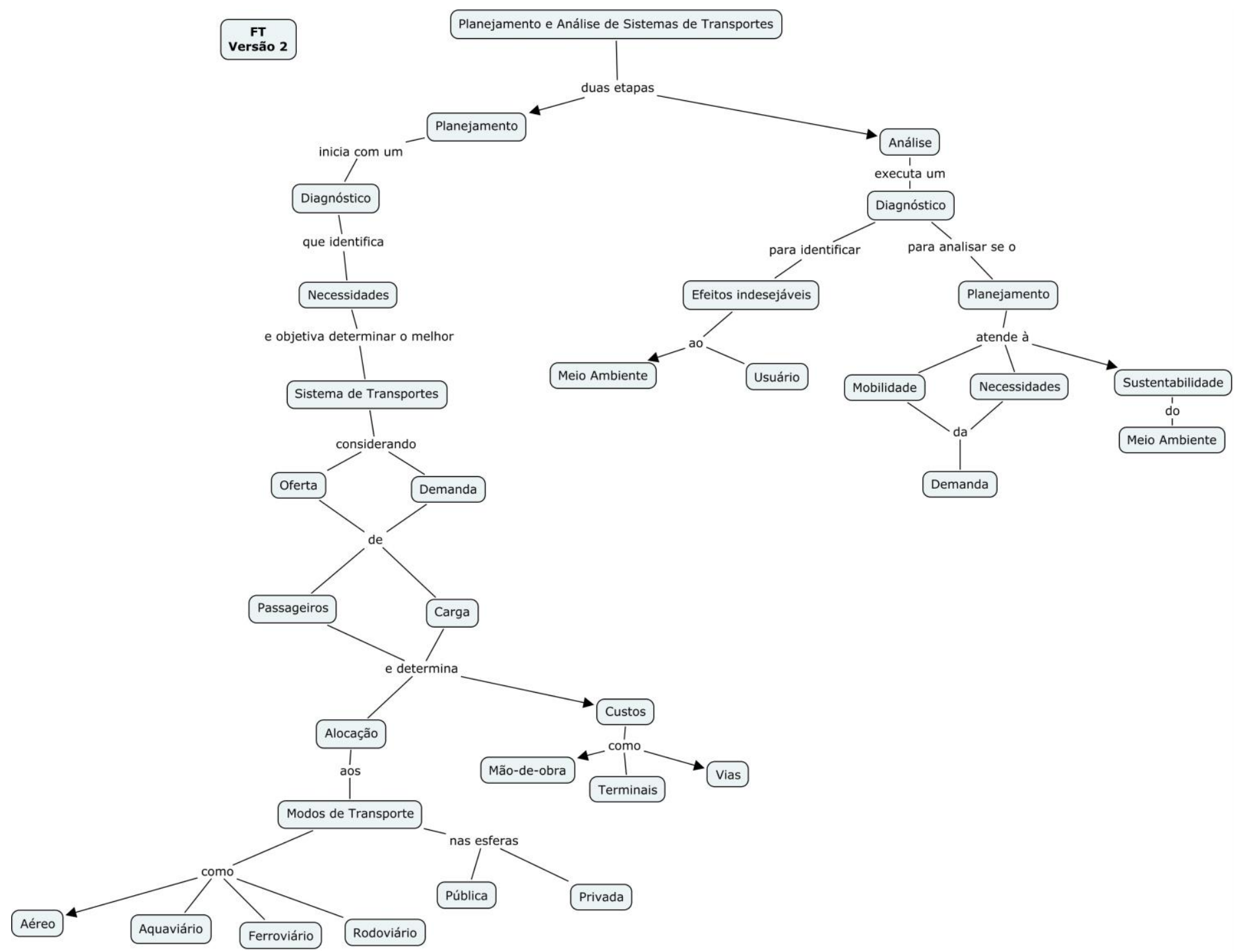




\section{Versão 3}

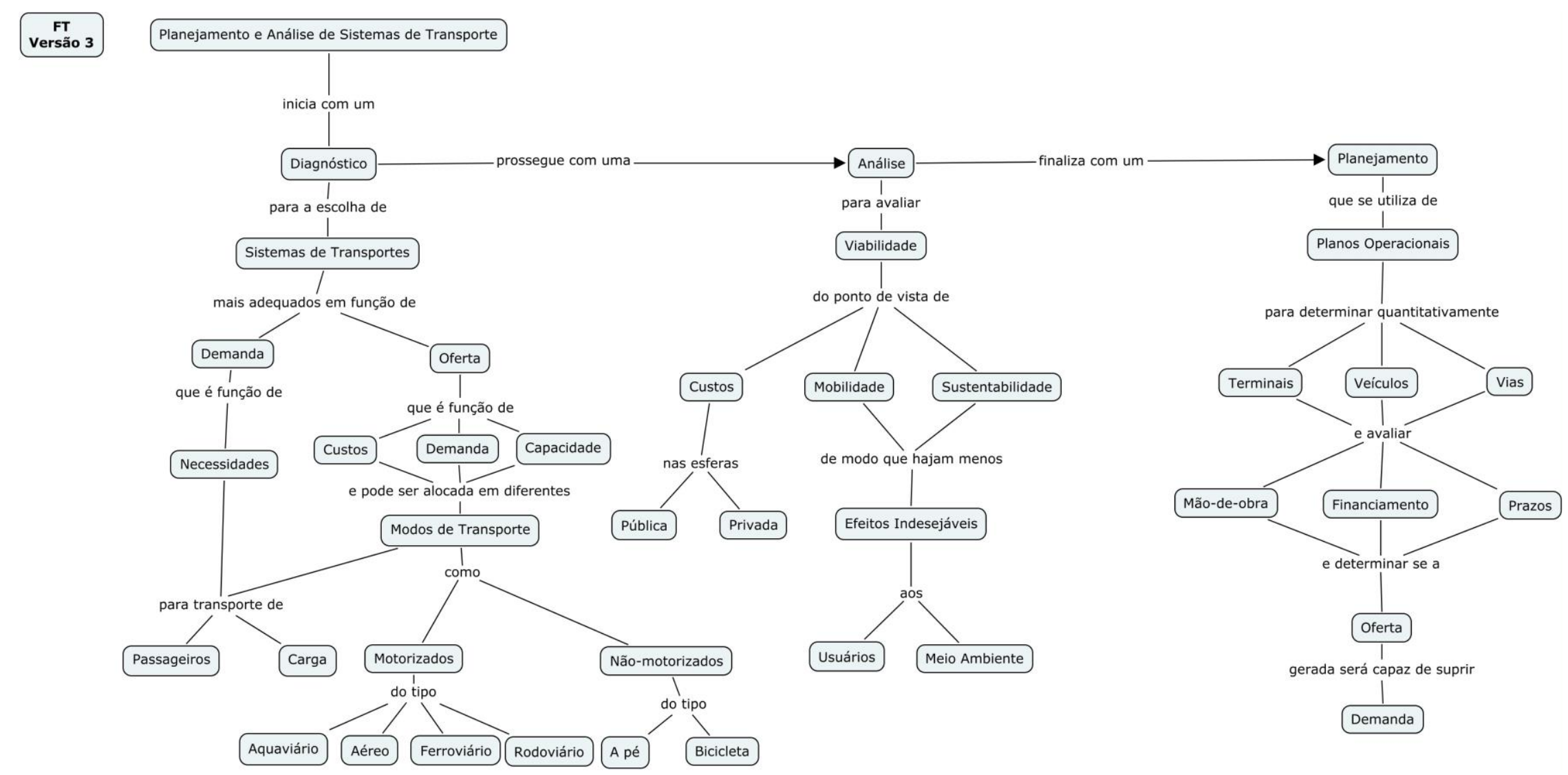




\section{RP - Versões 1, 2 e 3}

\section{Versão 1}

RP

Versão 1
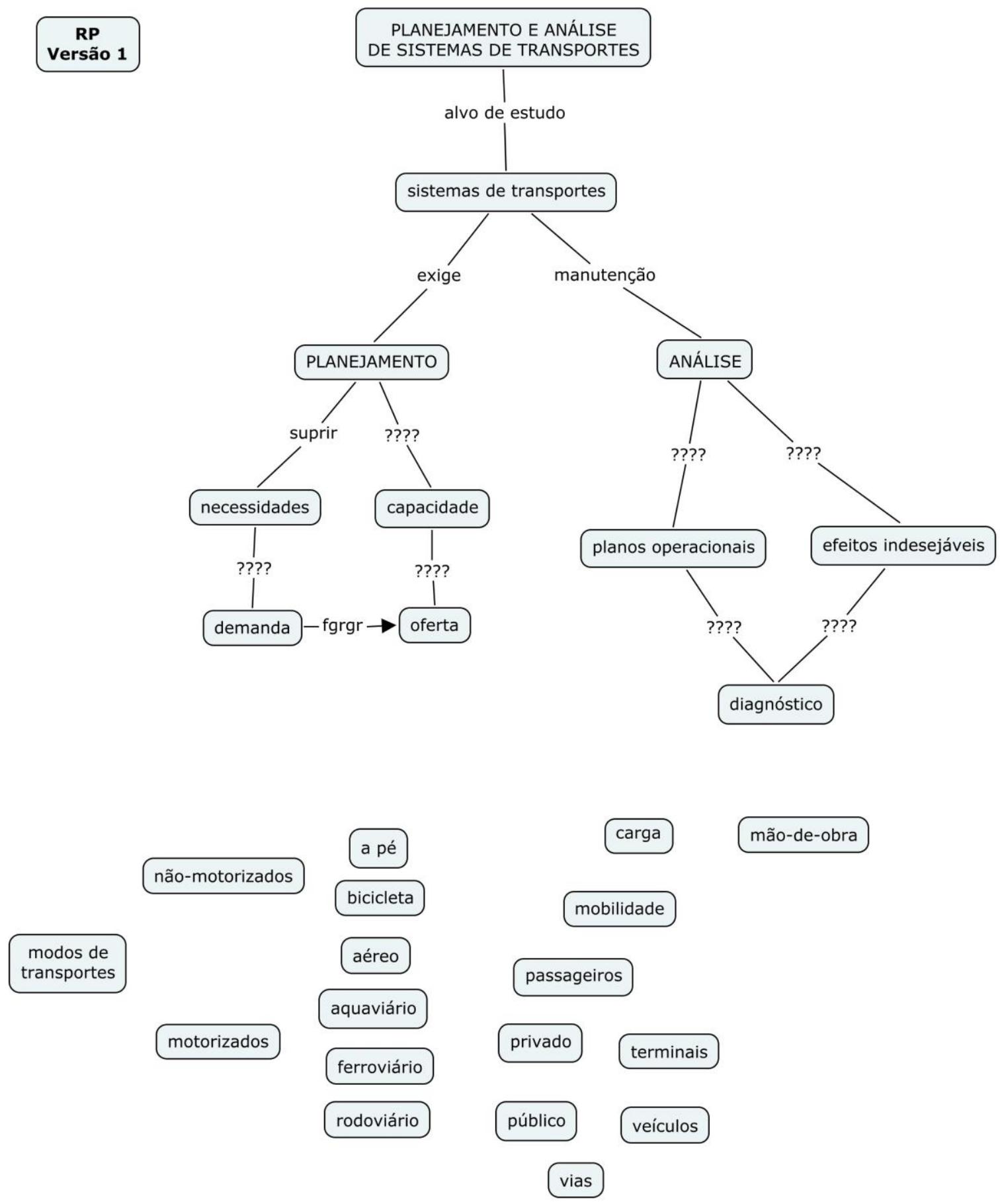


\section{Versão 2}

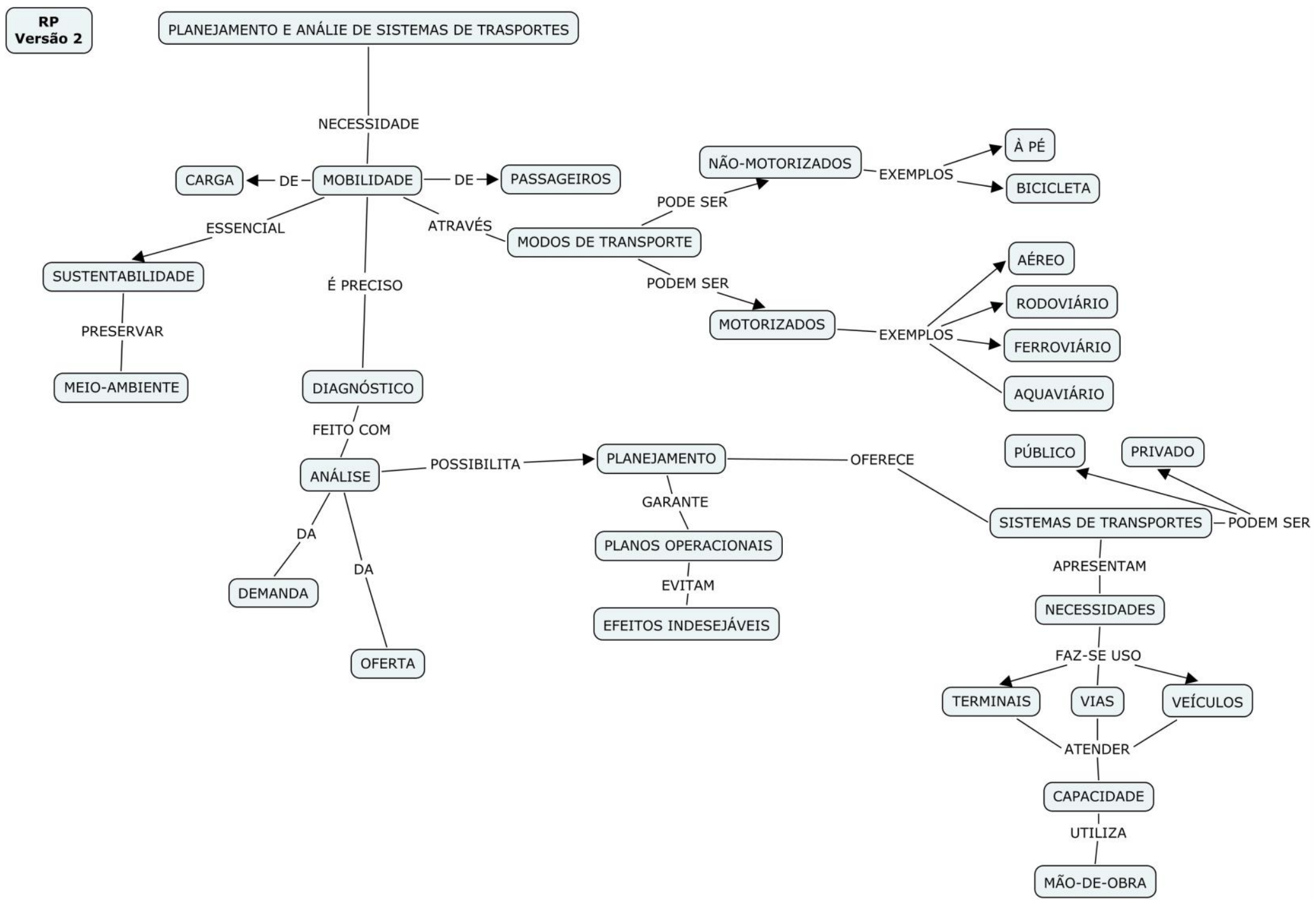




\section{Versão 3}

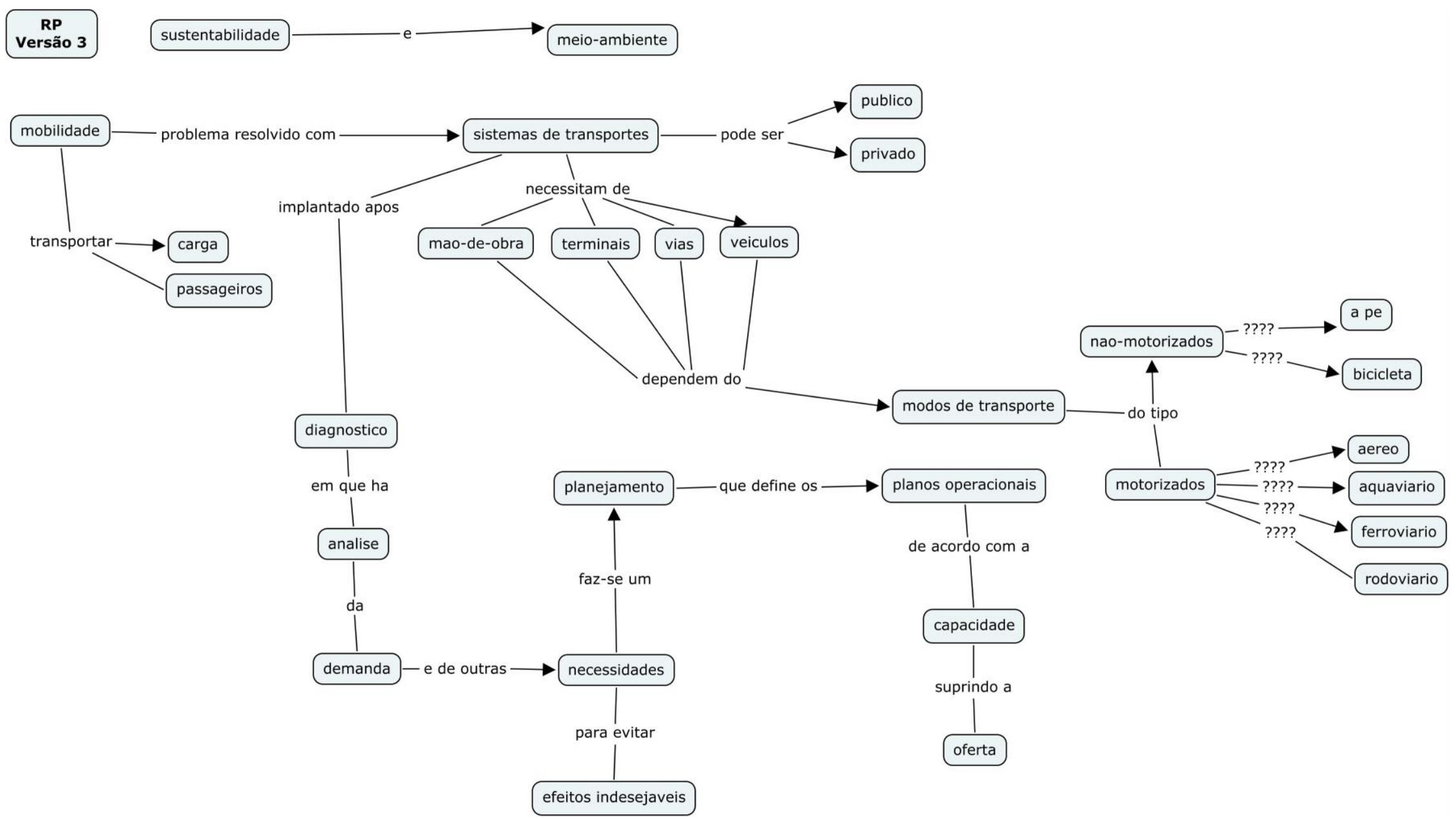




\section{VR - Versões 1, 2 e 3}

\section{Versão 1}

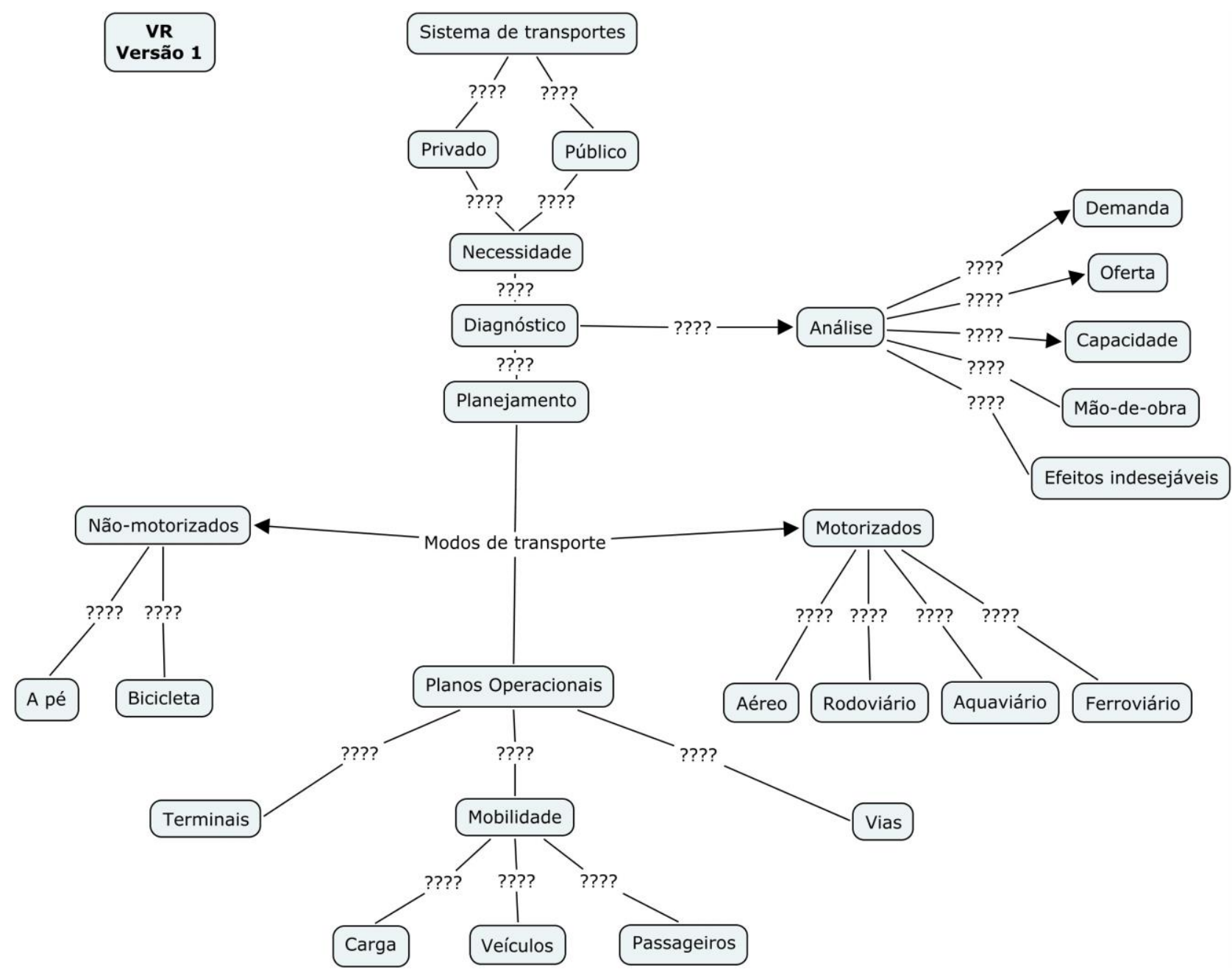


Versão 2

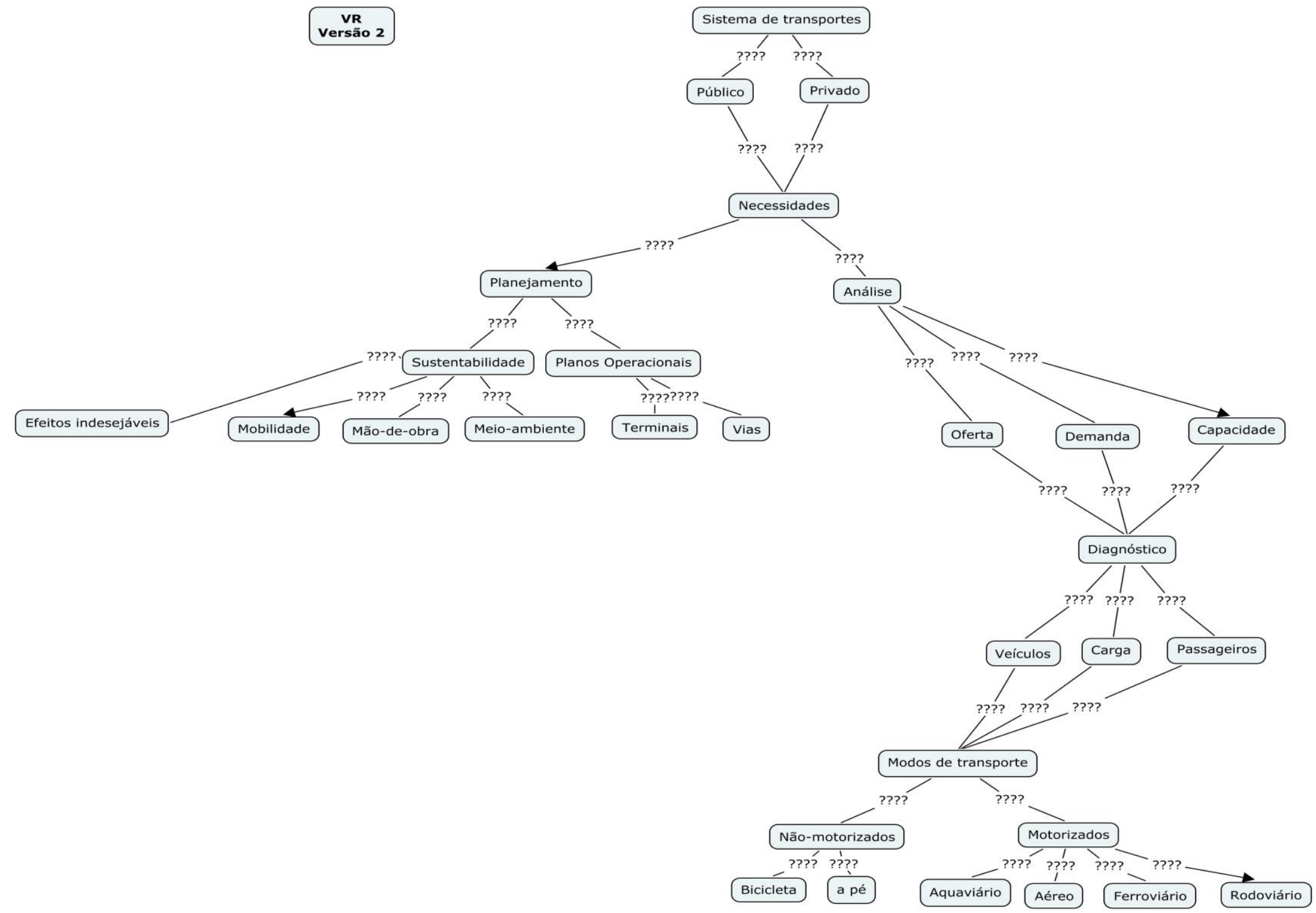




\section{Versão 3}

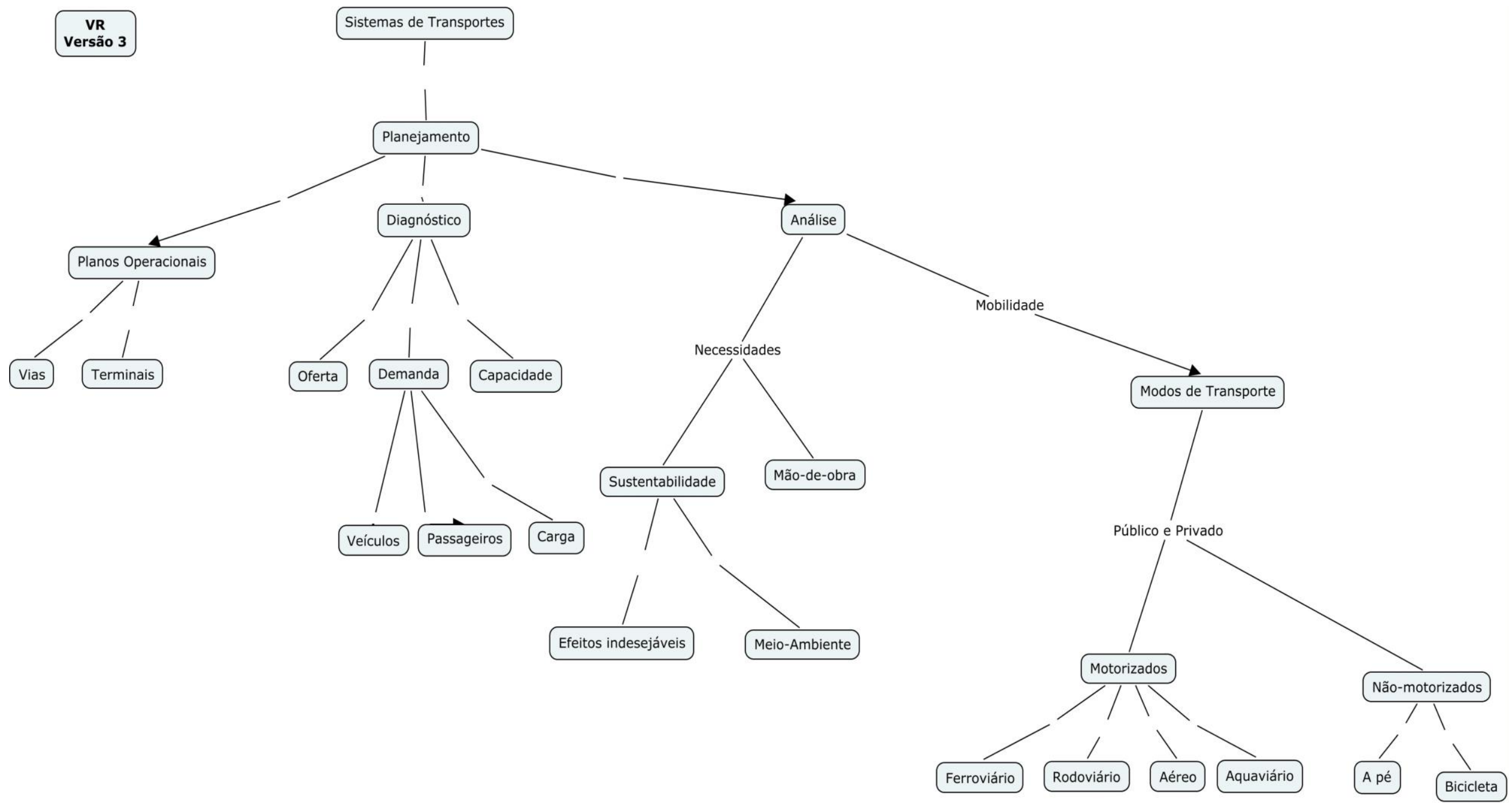




\section{WS - Versões 1, 2 e 3}

\section{Versão 1}

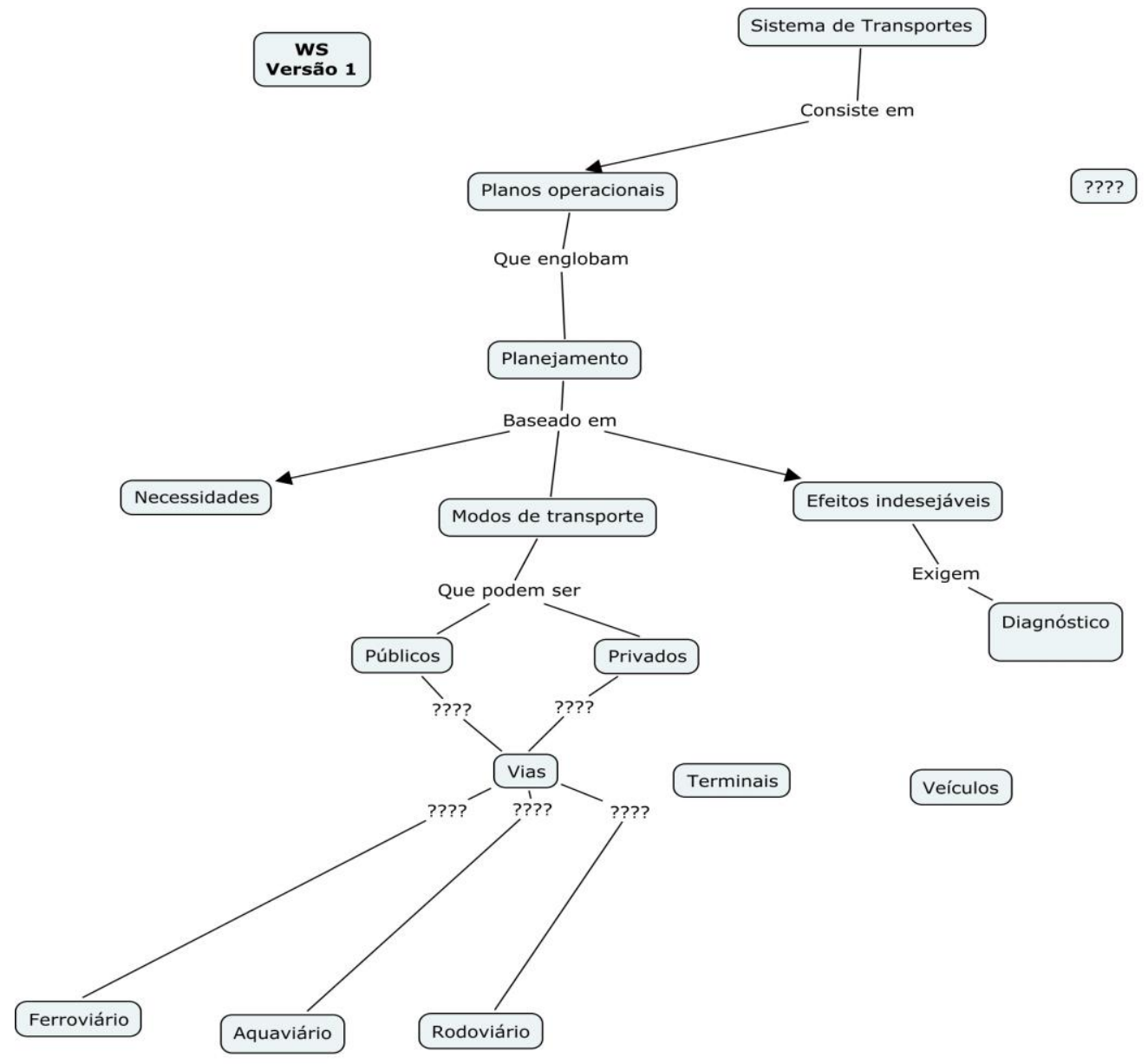


Versão 2

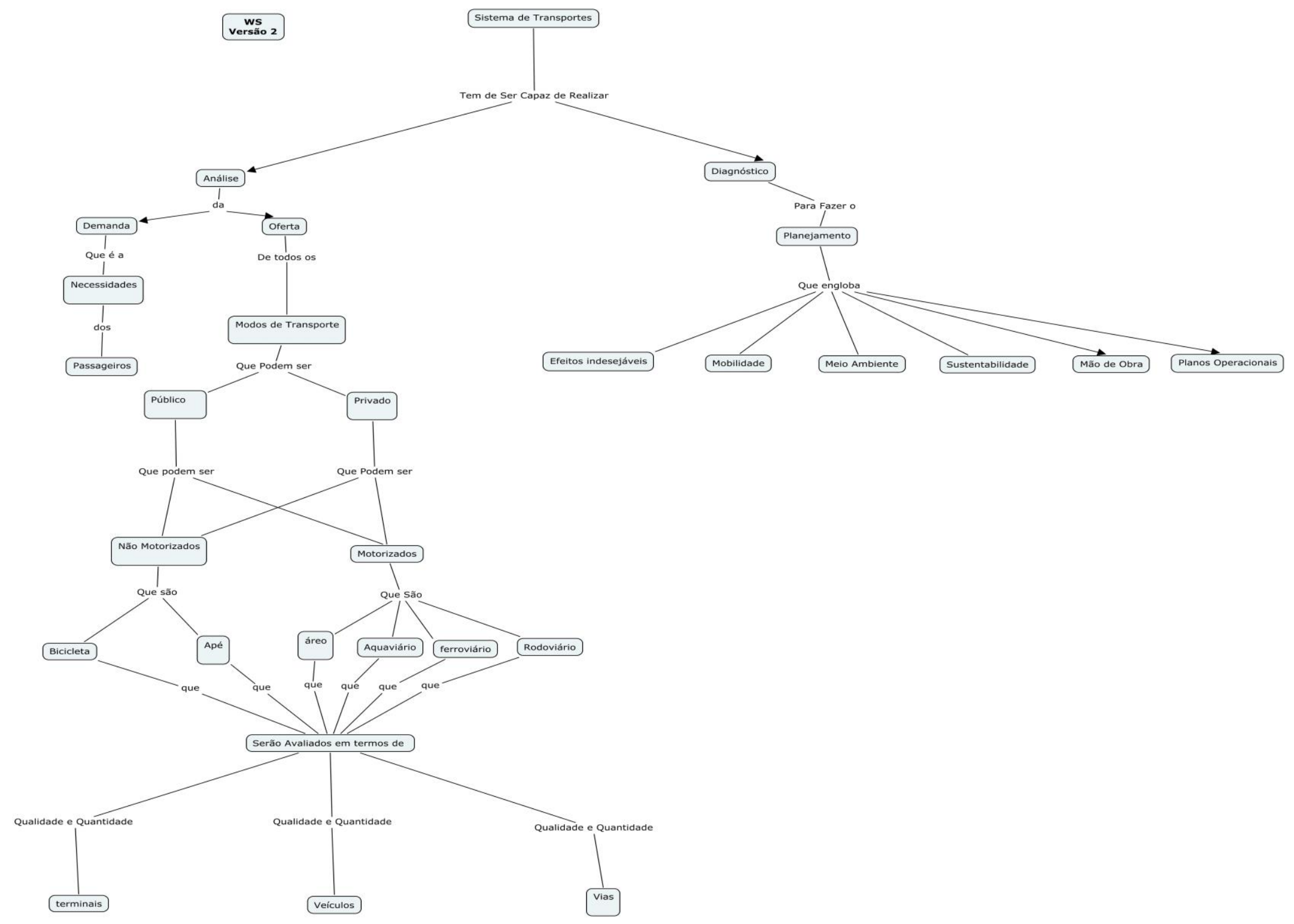




\section{Versão 3}

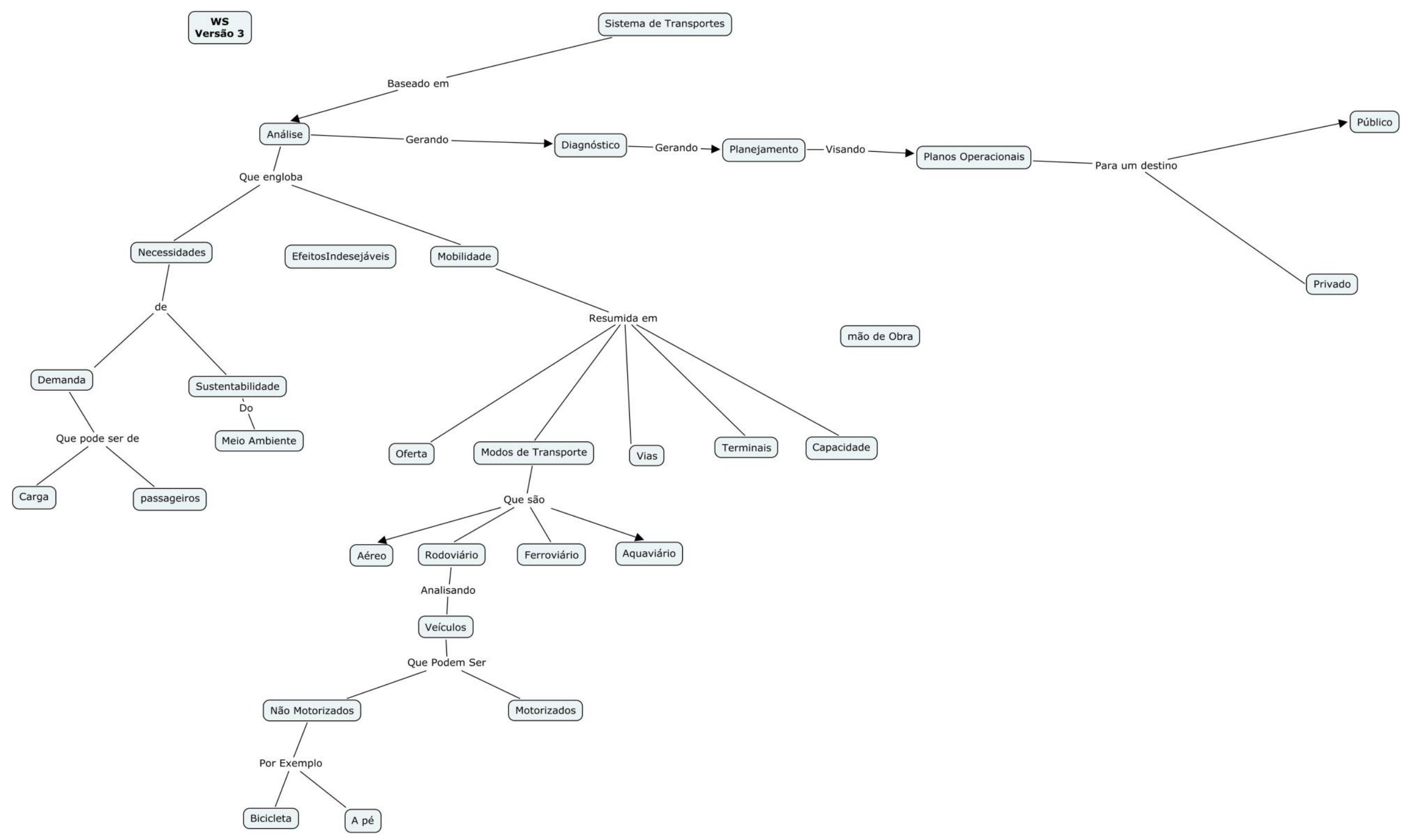




\section{Mapas - Turma 1 de 2013}

GMM - Versões 1, 2 e 3

Versão 1

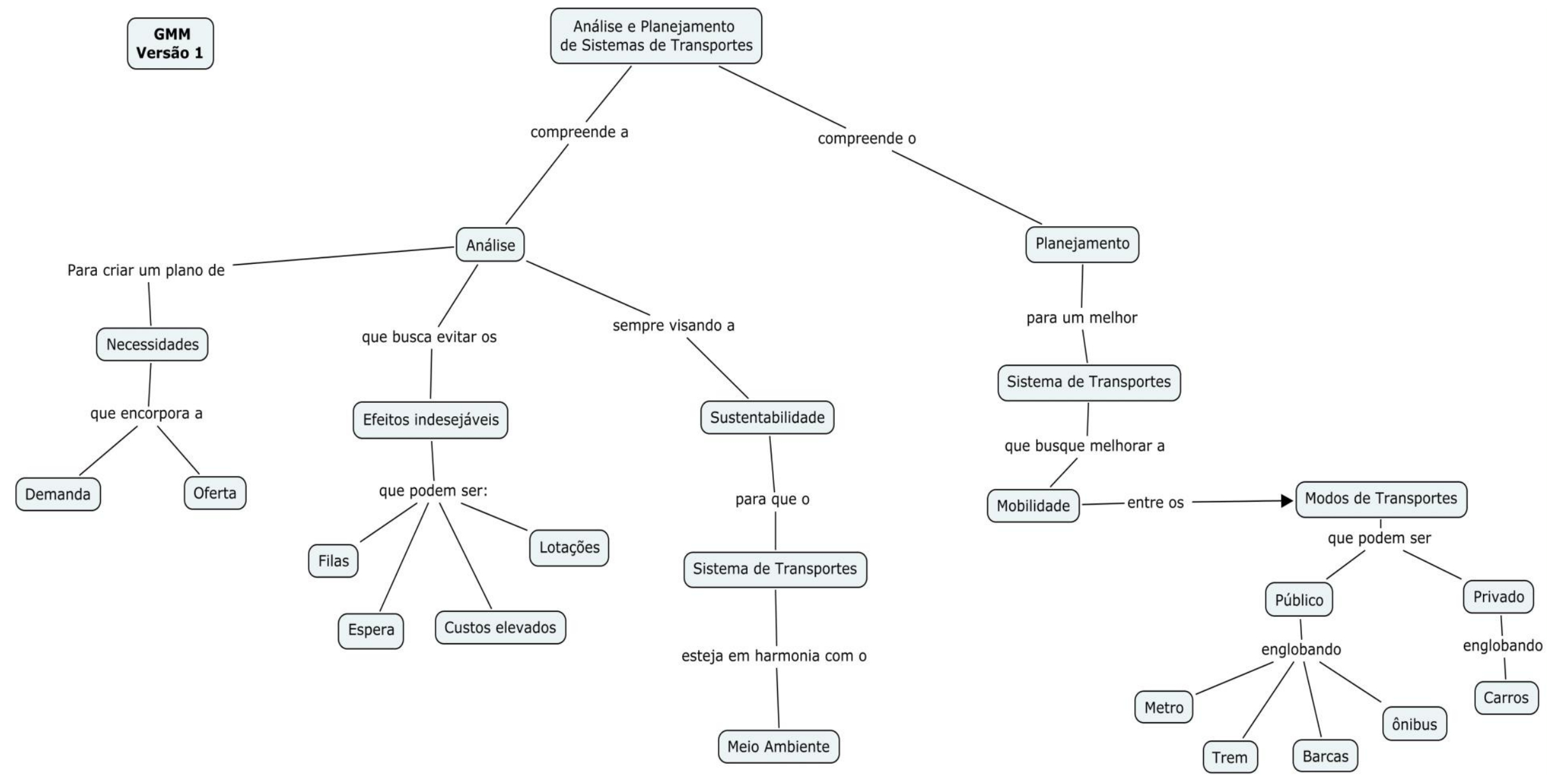




\section{Versão 2}

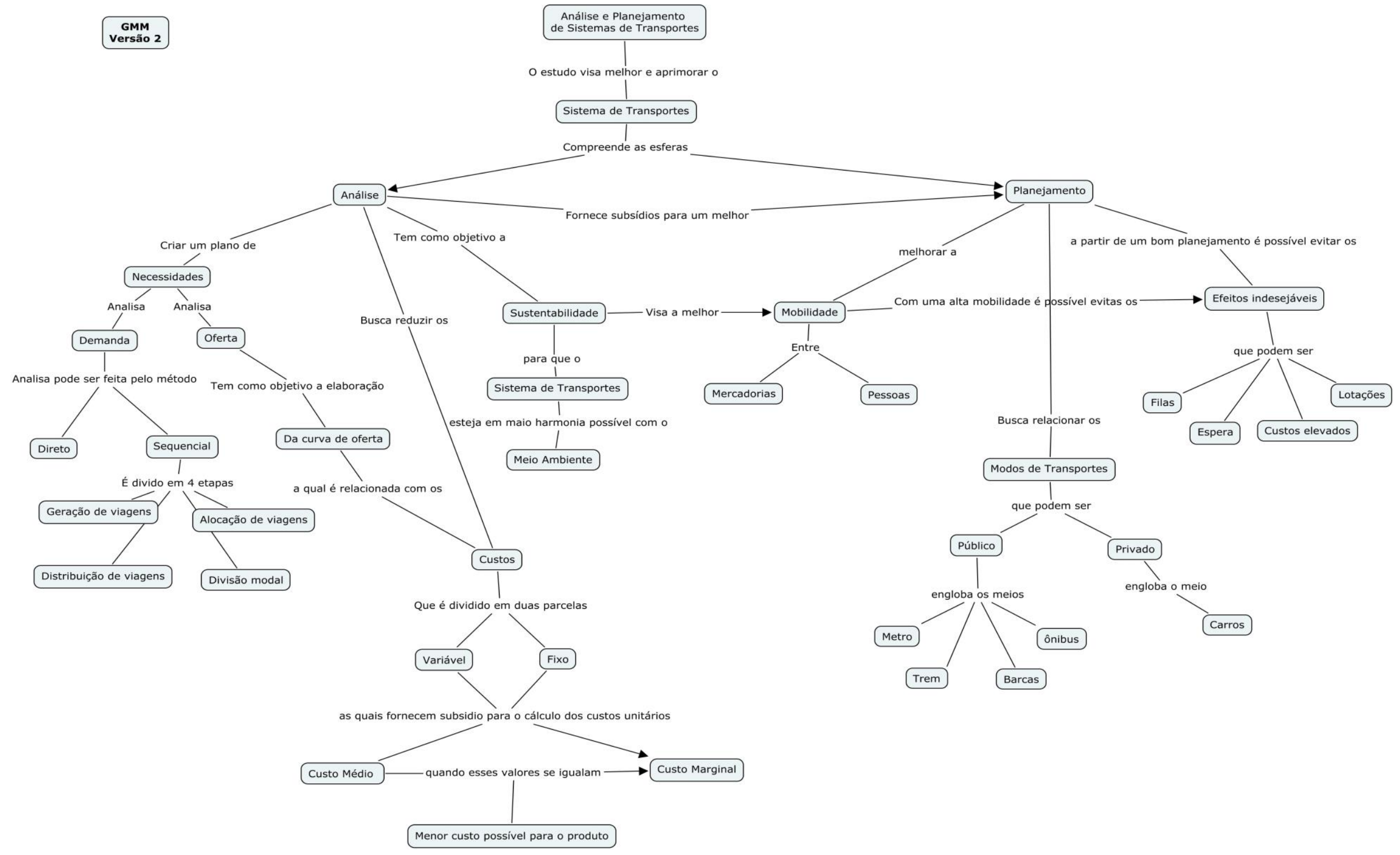




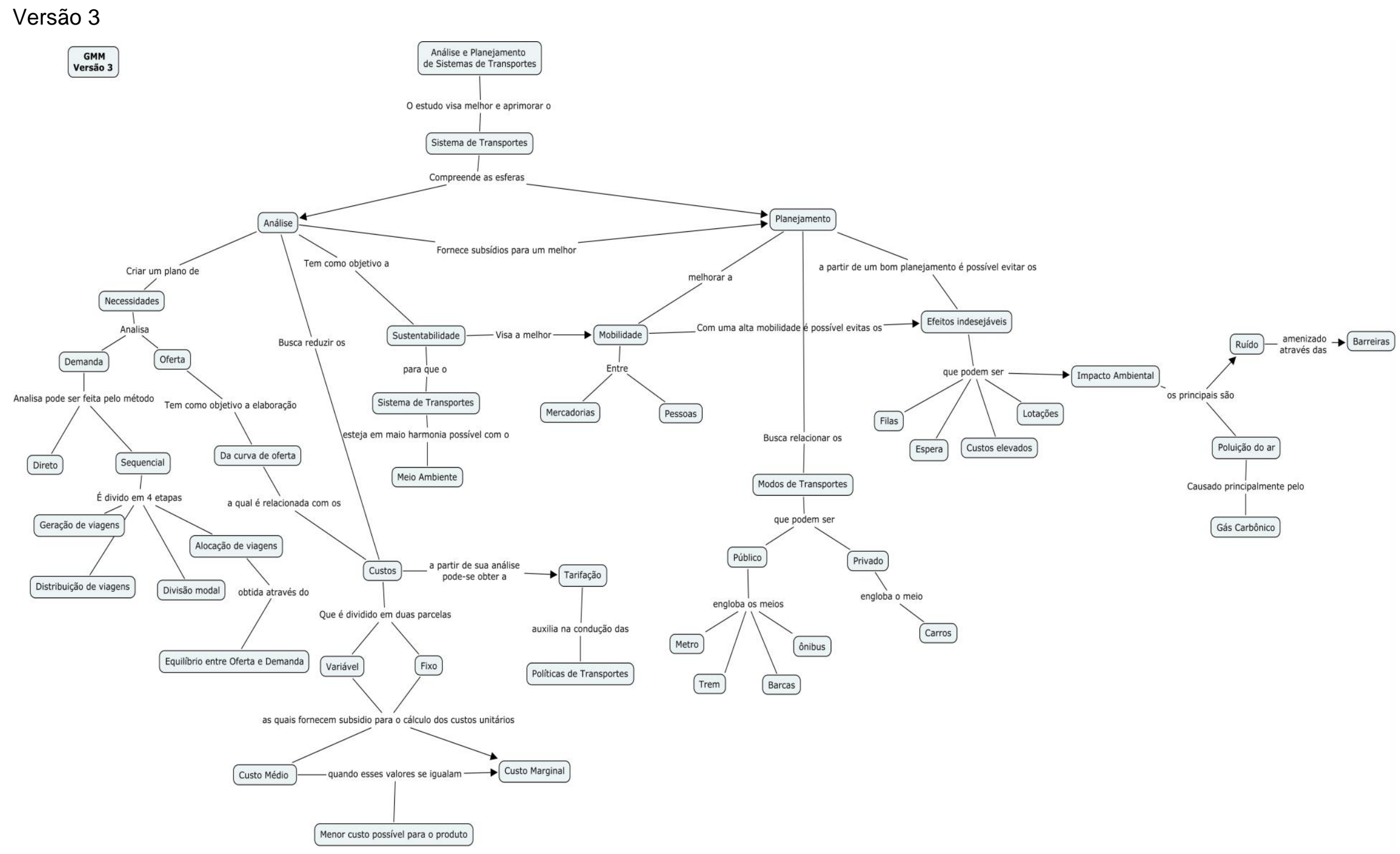




\section{PL - Versões 1, 2 e 3}

\section{Versão 1}

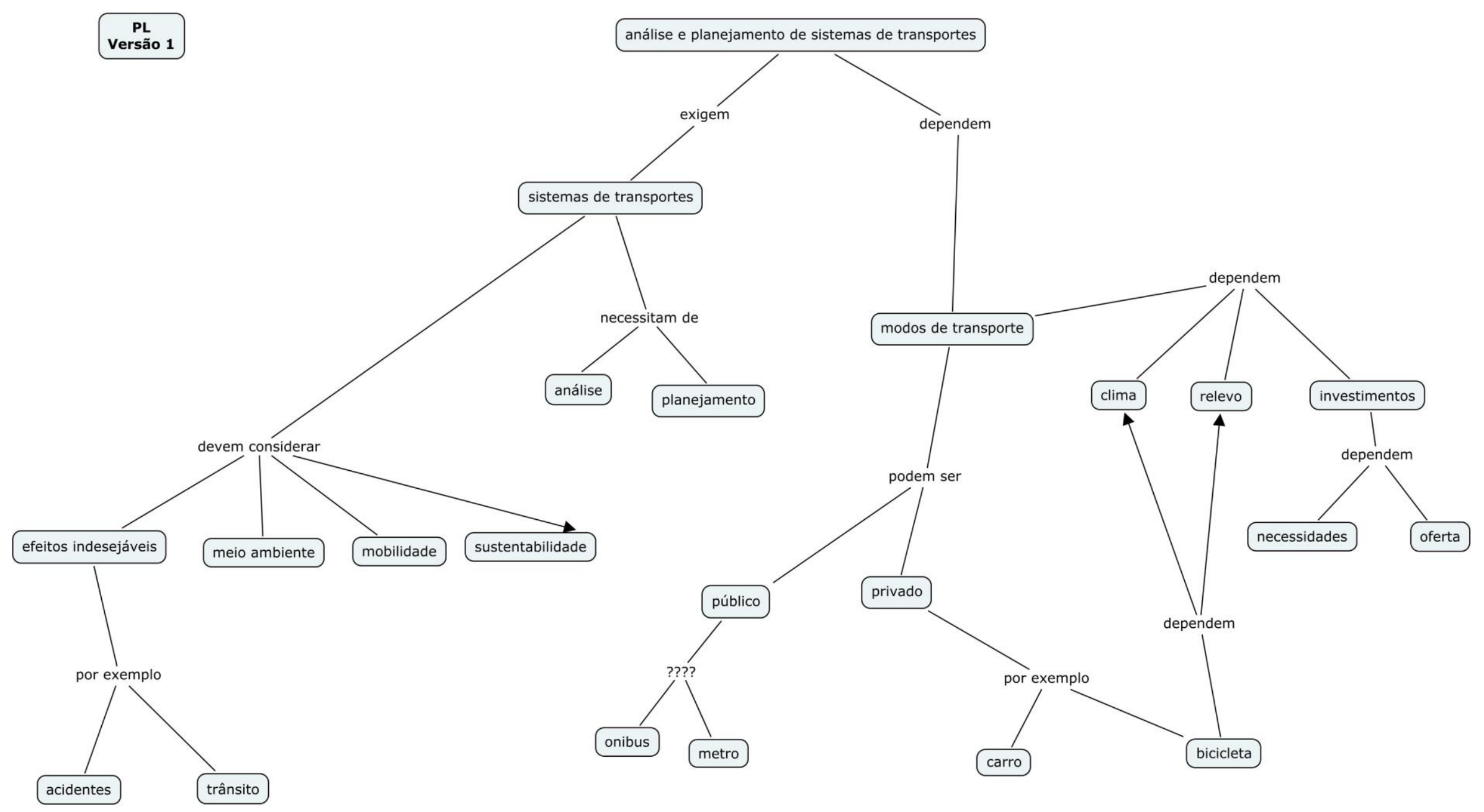




\section{Versão 2}

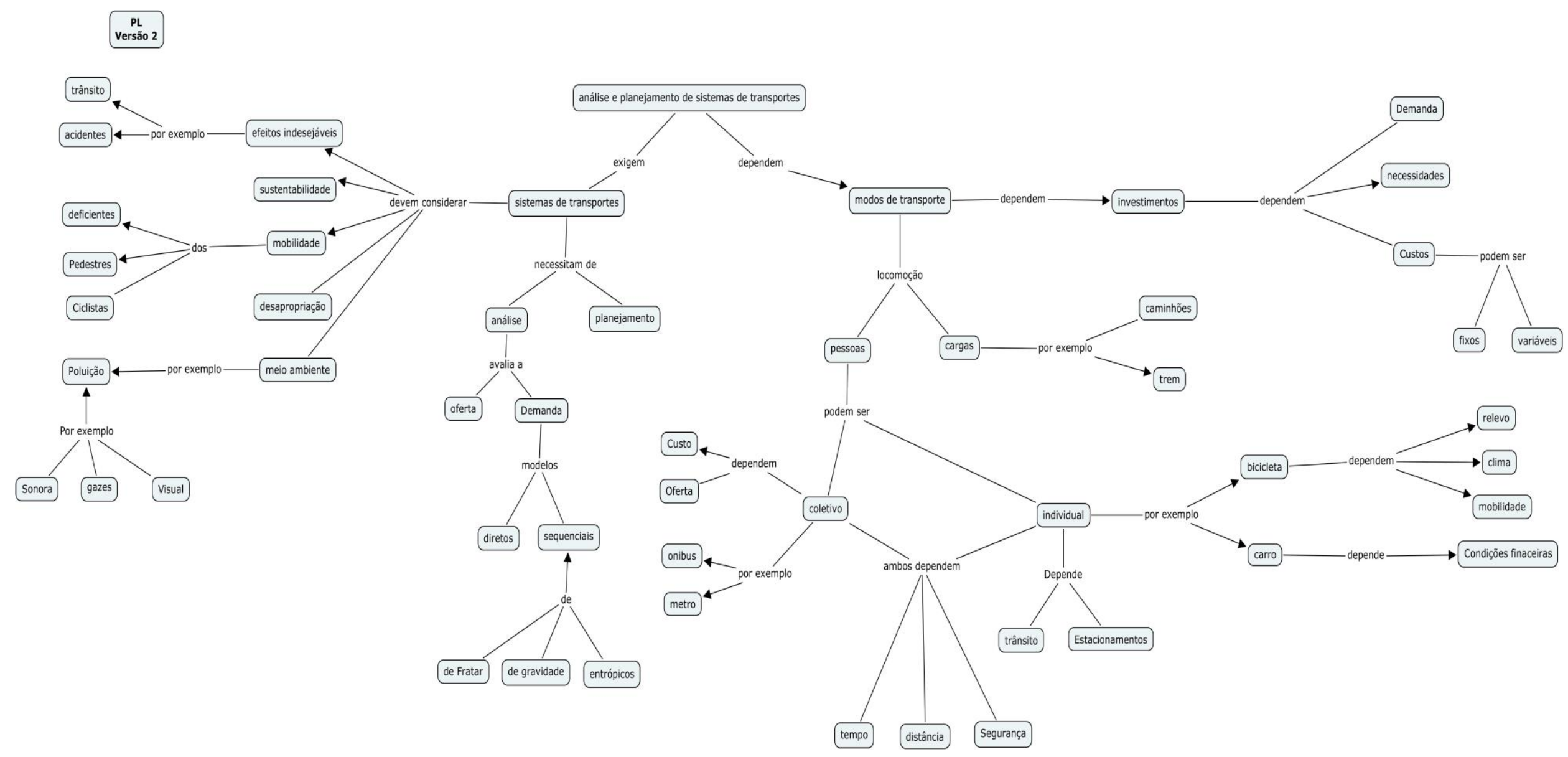




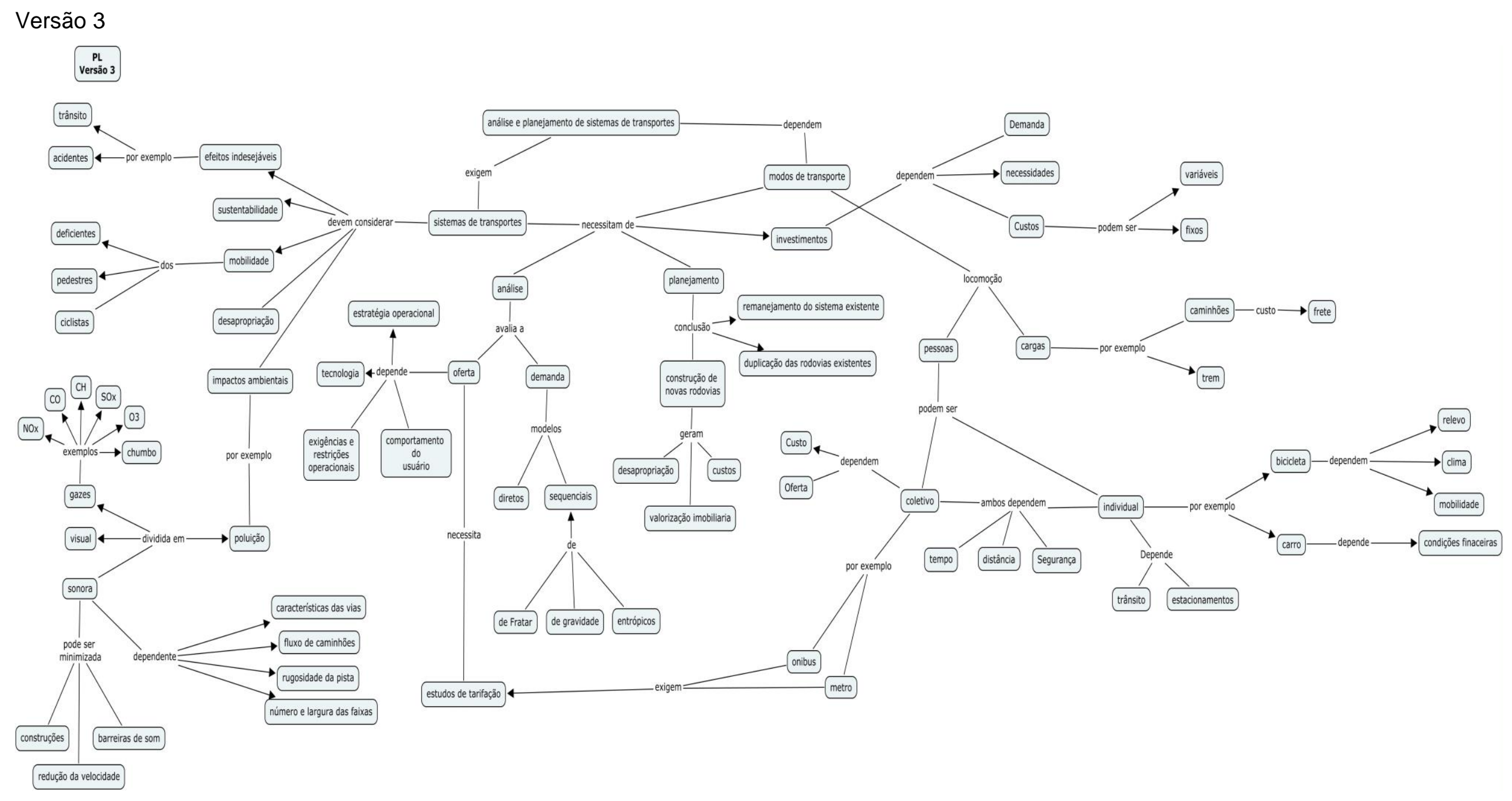




\section{LH - Versões 1, 2 e 3}

\section{Versão 1}

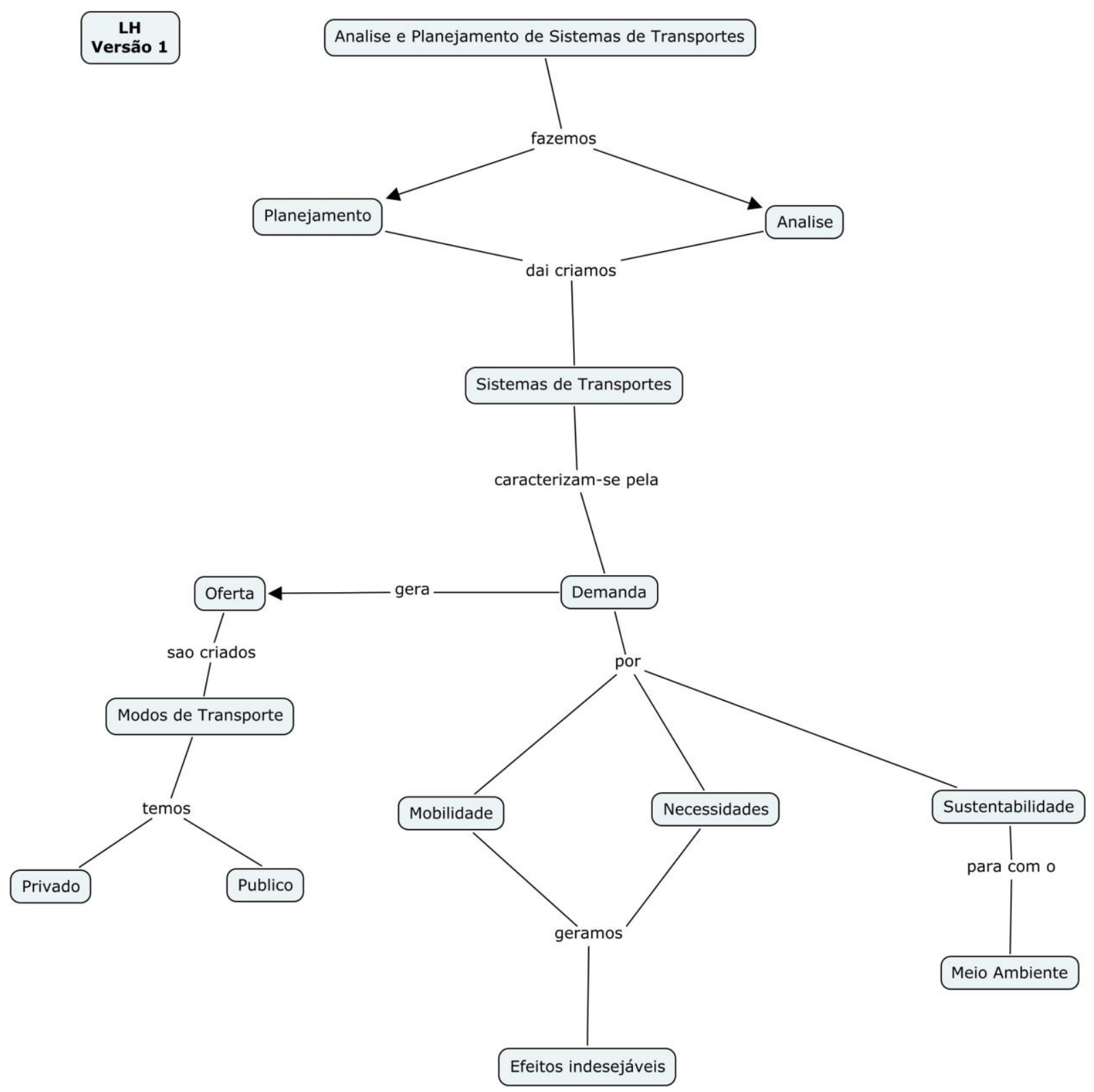




\section{Versão 2}

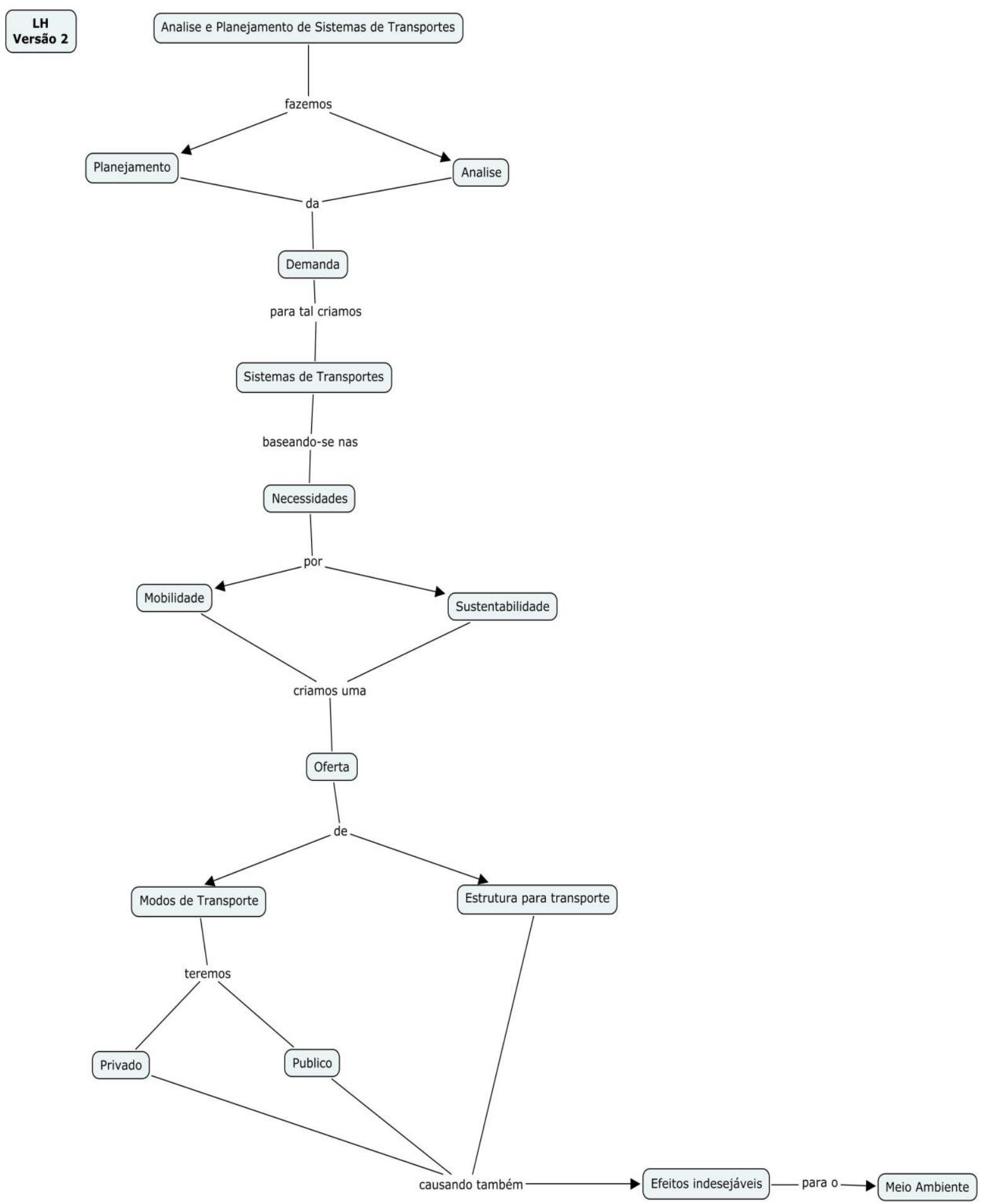




\section{Versão 3}

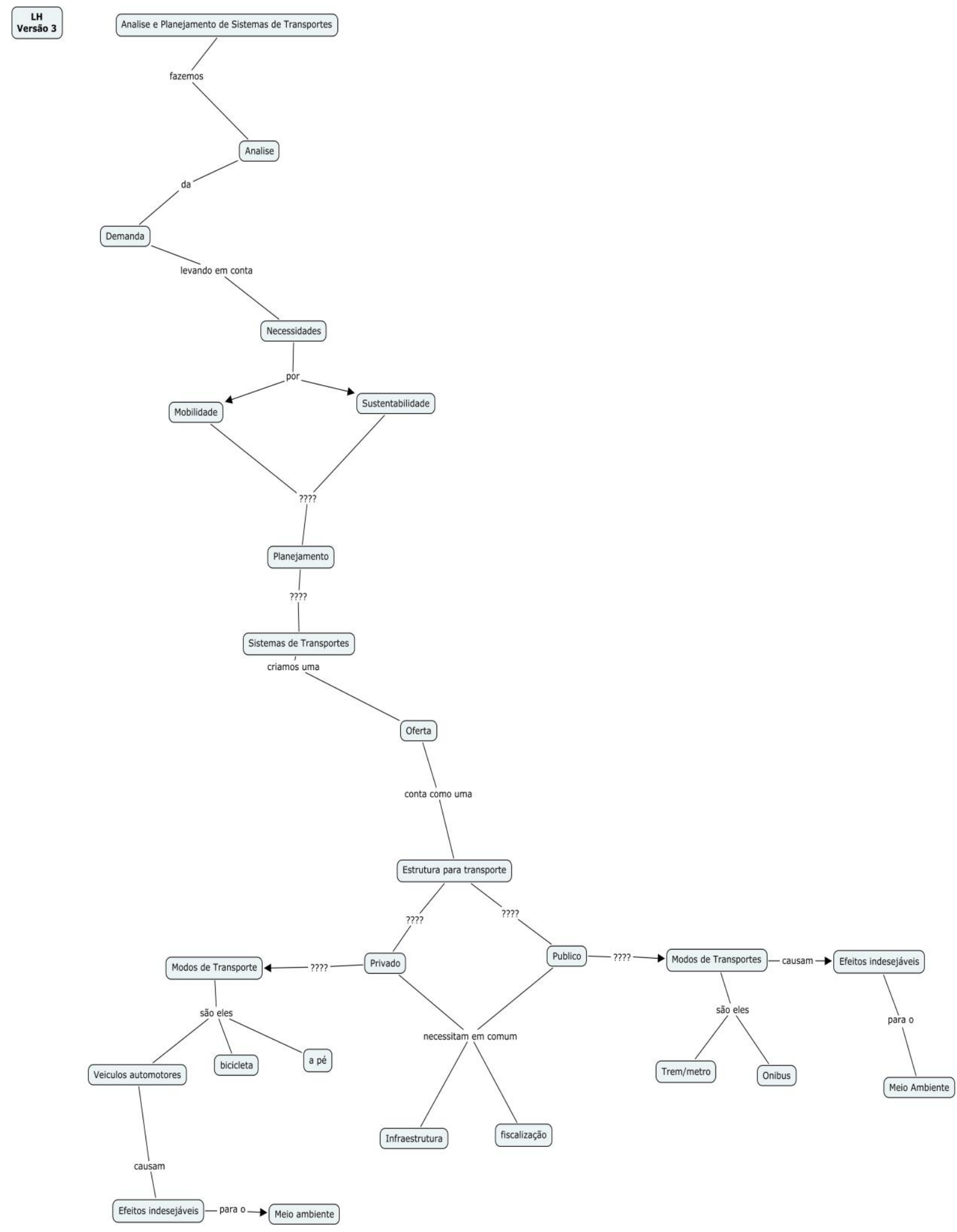




\section{MC - Versões 1, 2 e 3}

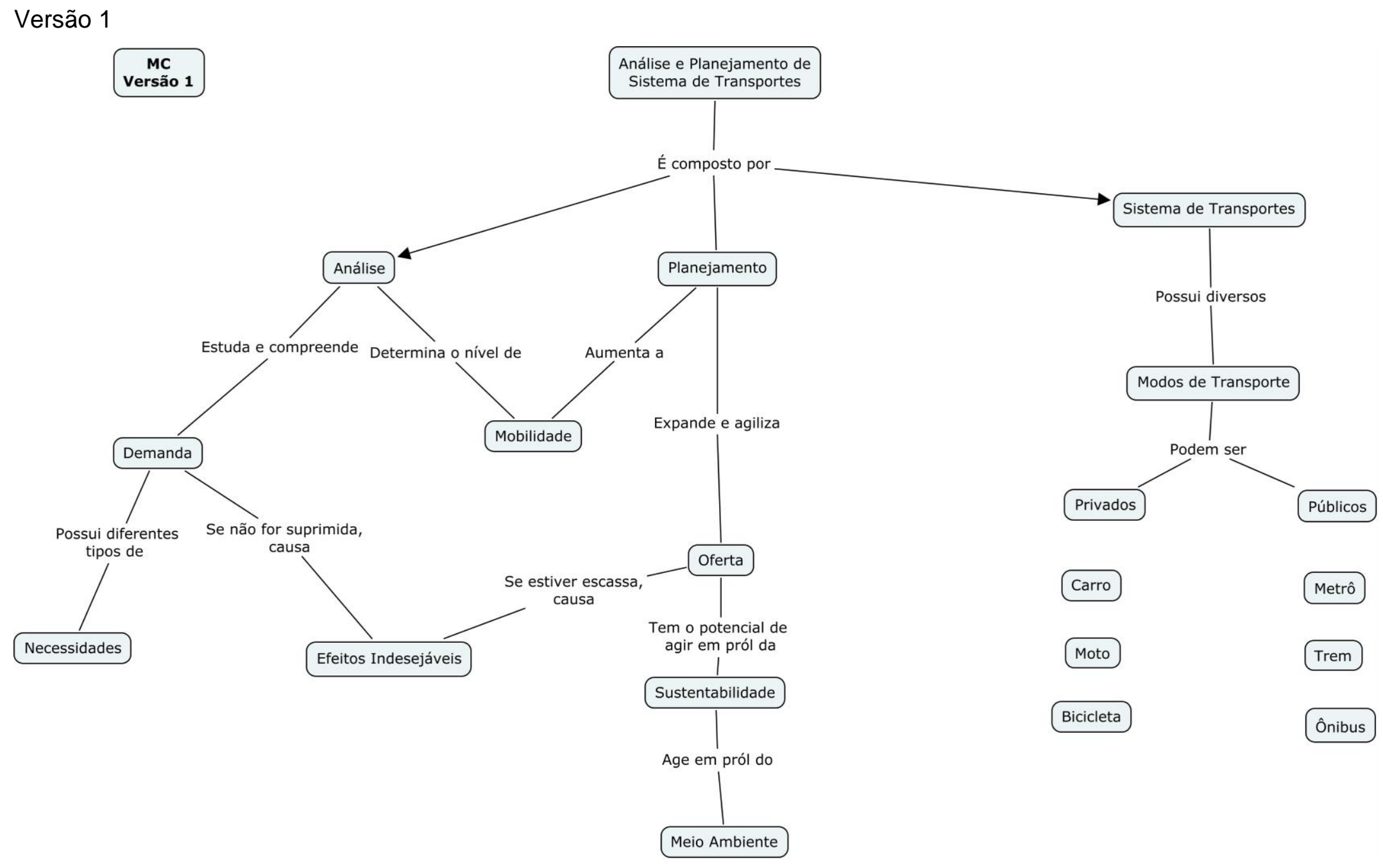




\section{Versão 2}

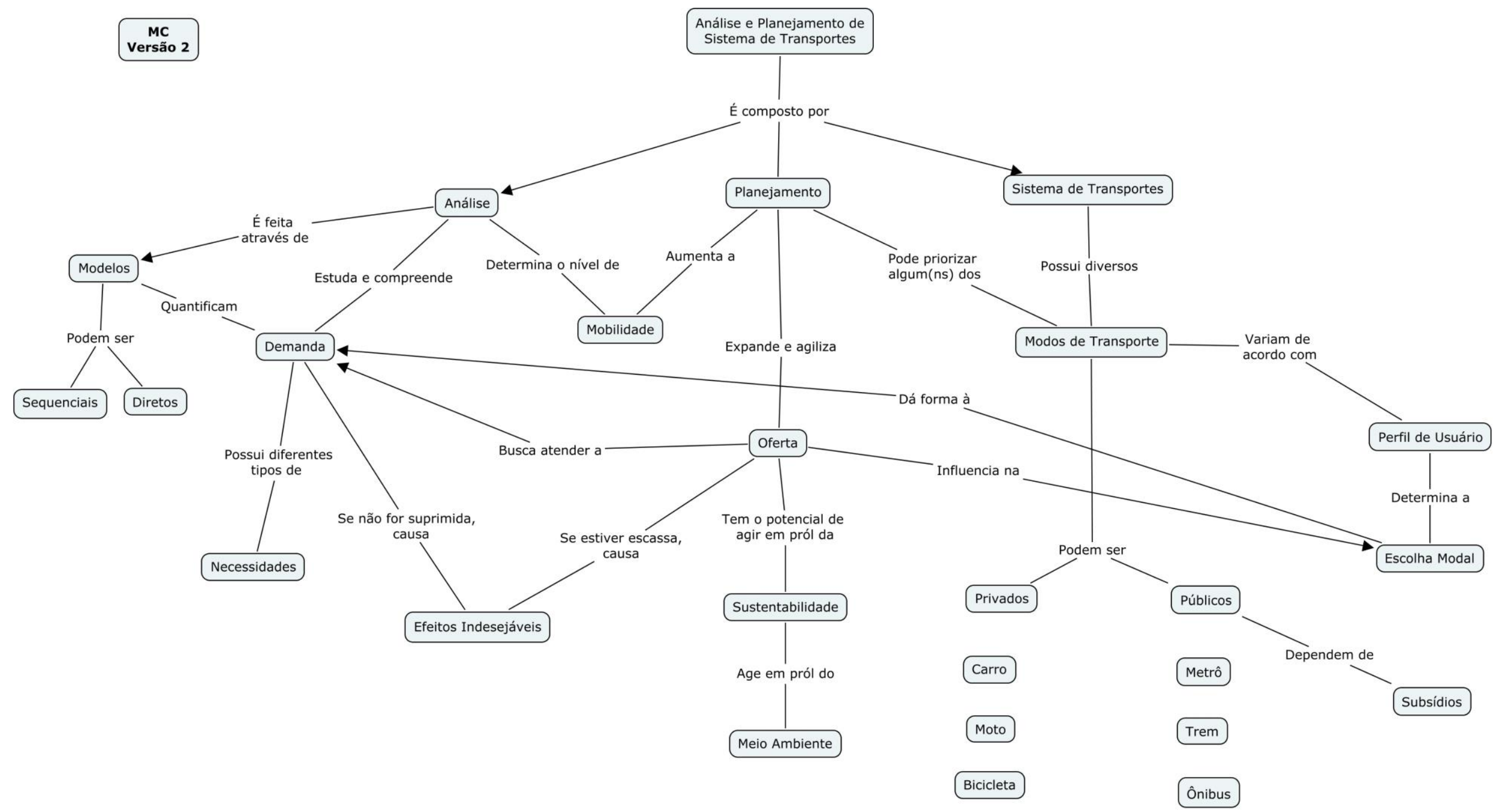




\section{Versão 3}

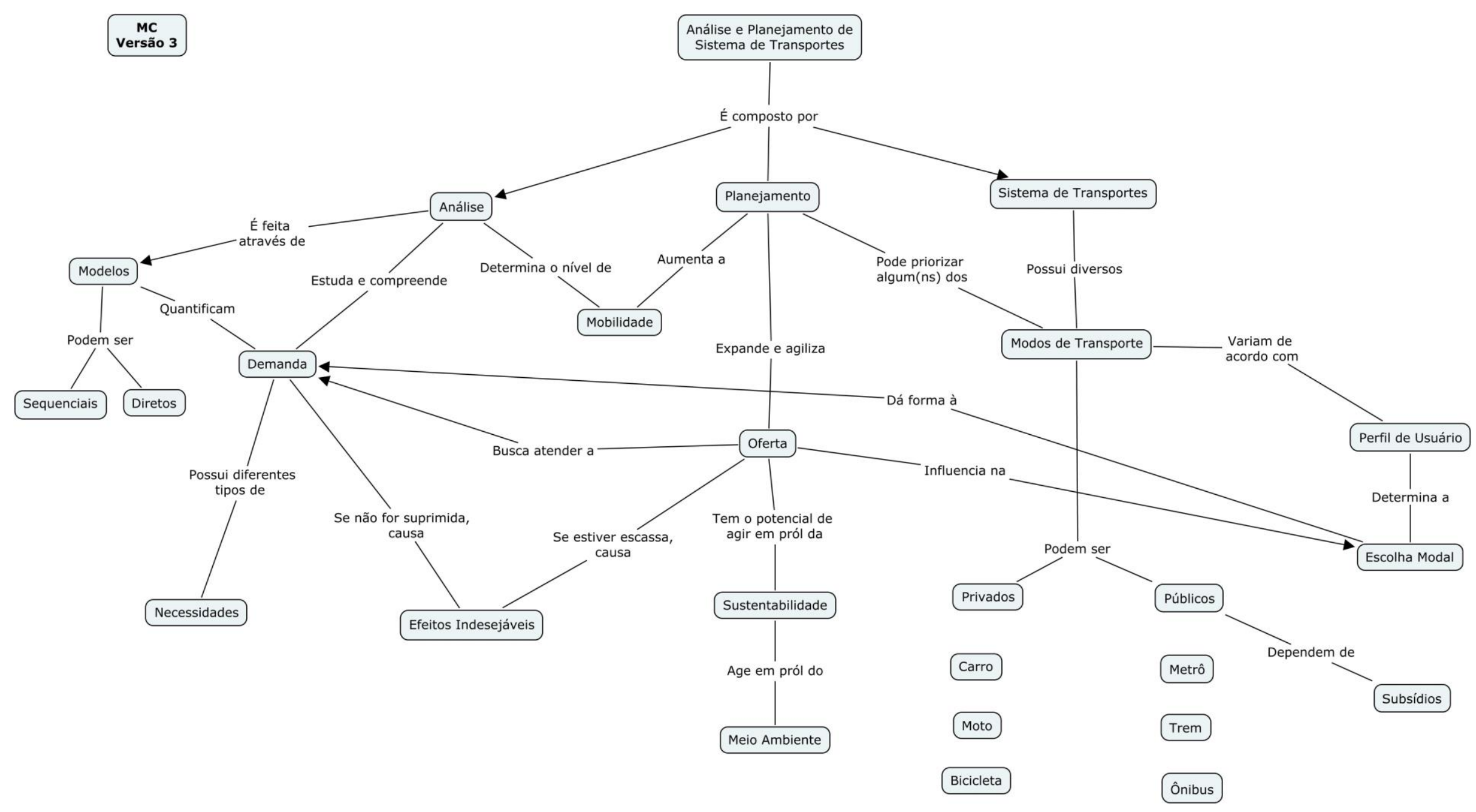




\section{Mapas - Turma 2 de 2013}

CR - Versões 1, 2 e 3

\section{Versão 1}

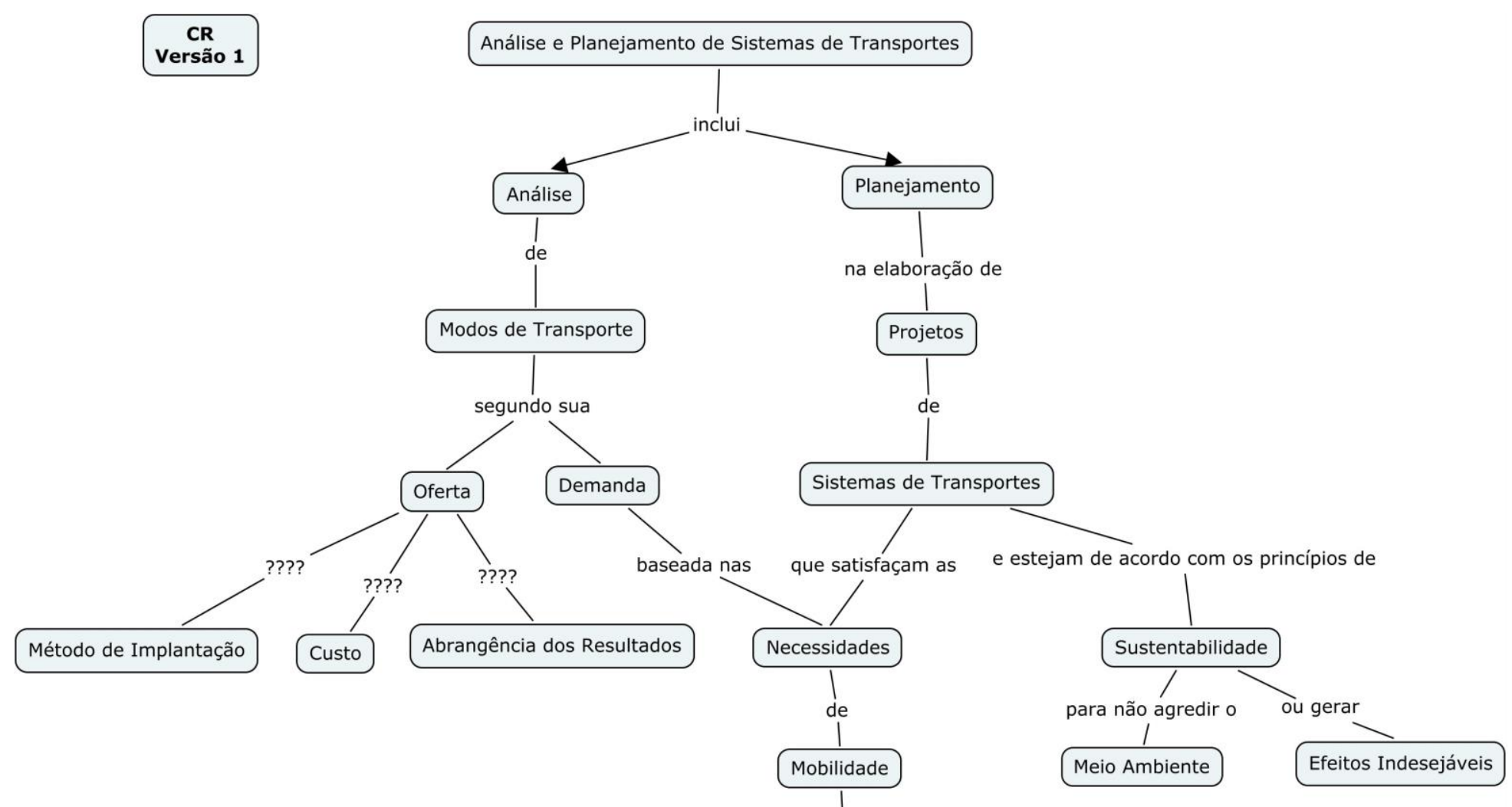

da população, conciliando os sistemas de transporte

$$
\text { Público Privado }
$$


Versão 2

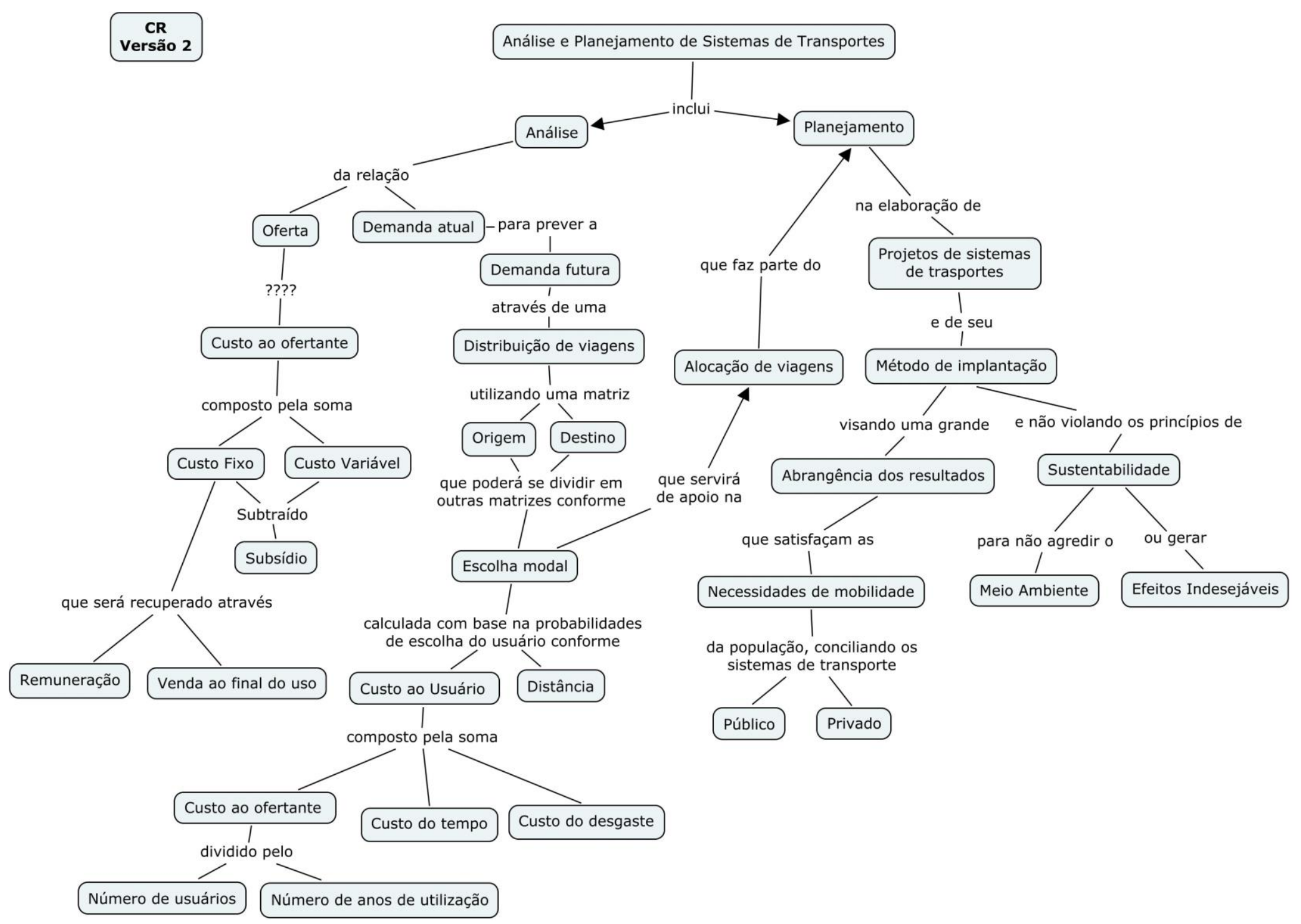




\section{Versão 3}

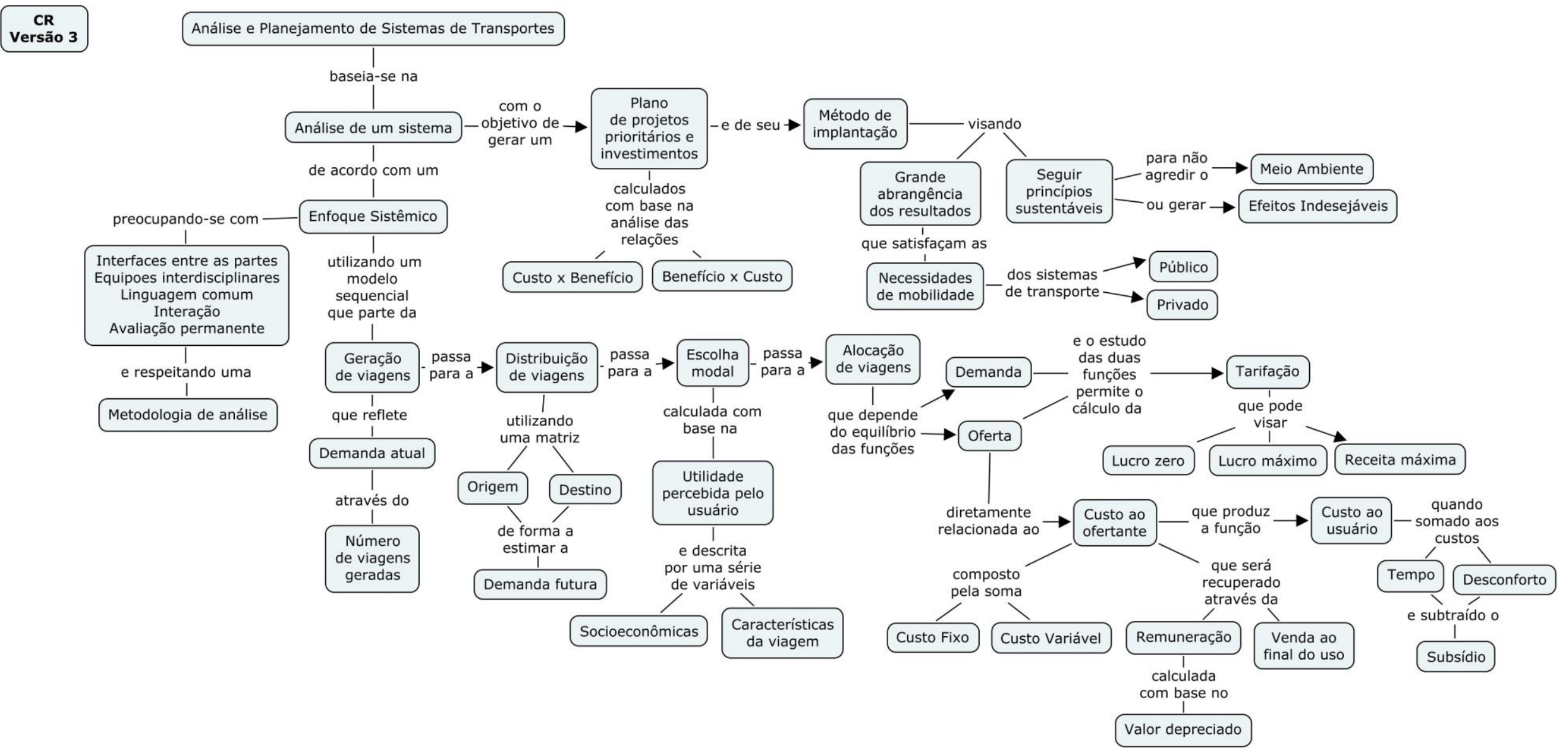




\section{MYM - Versões 1, 2 e 3}

Versão 1

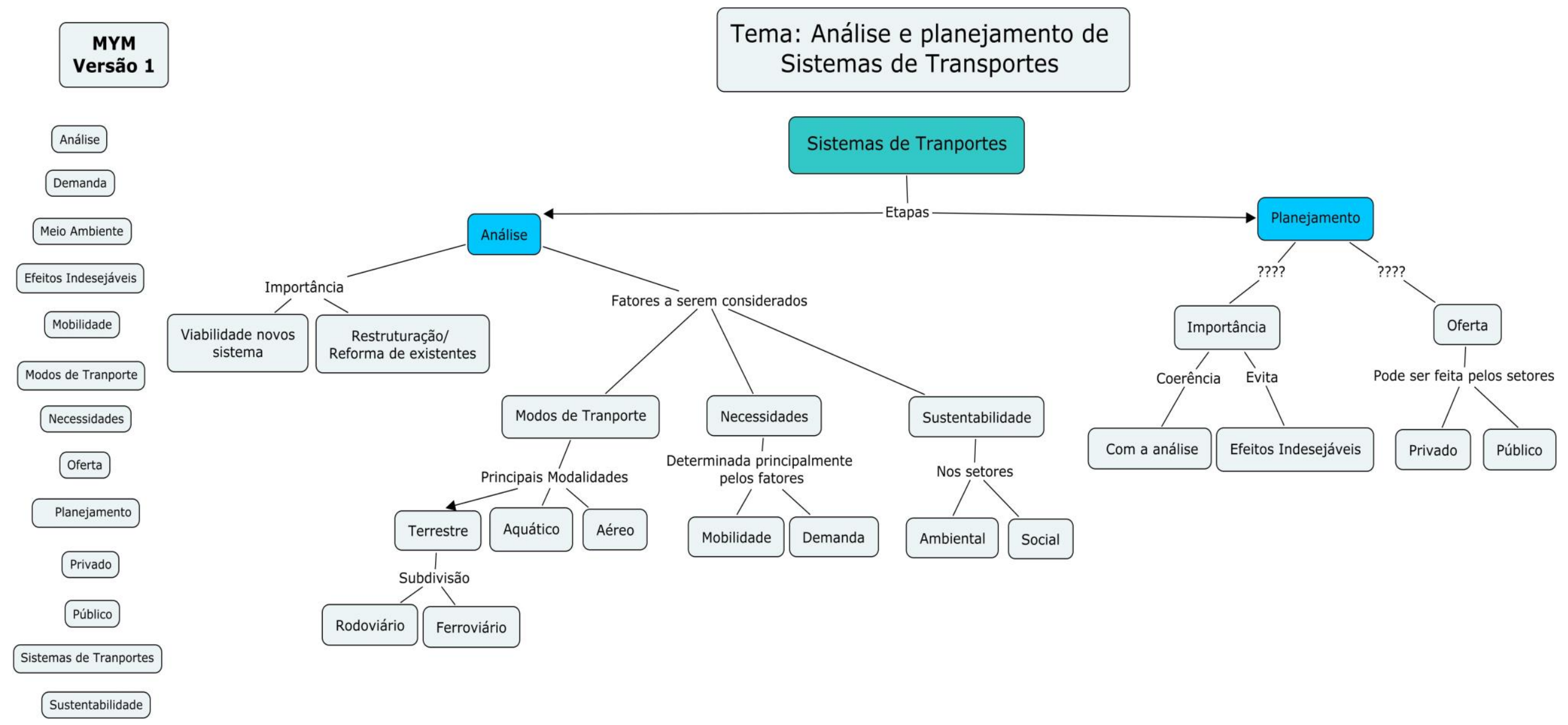


Versão 2

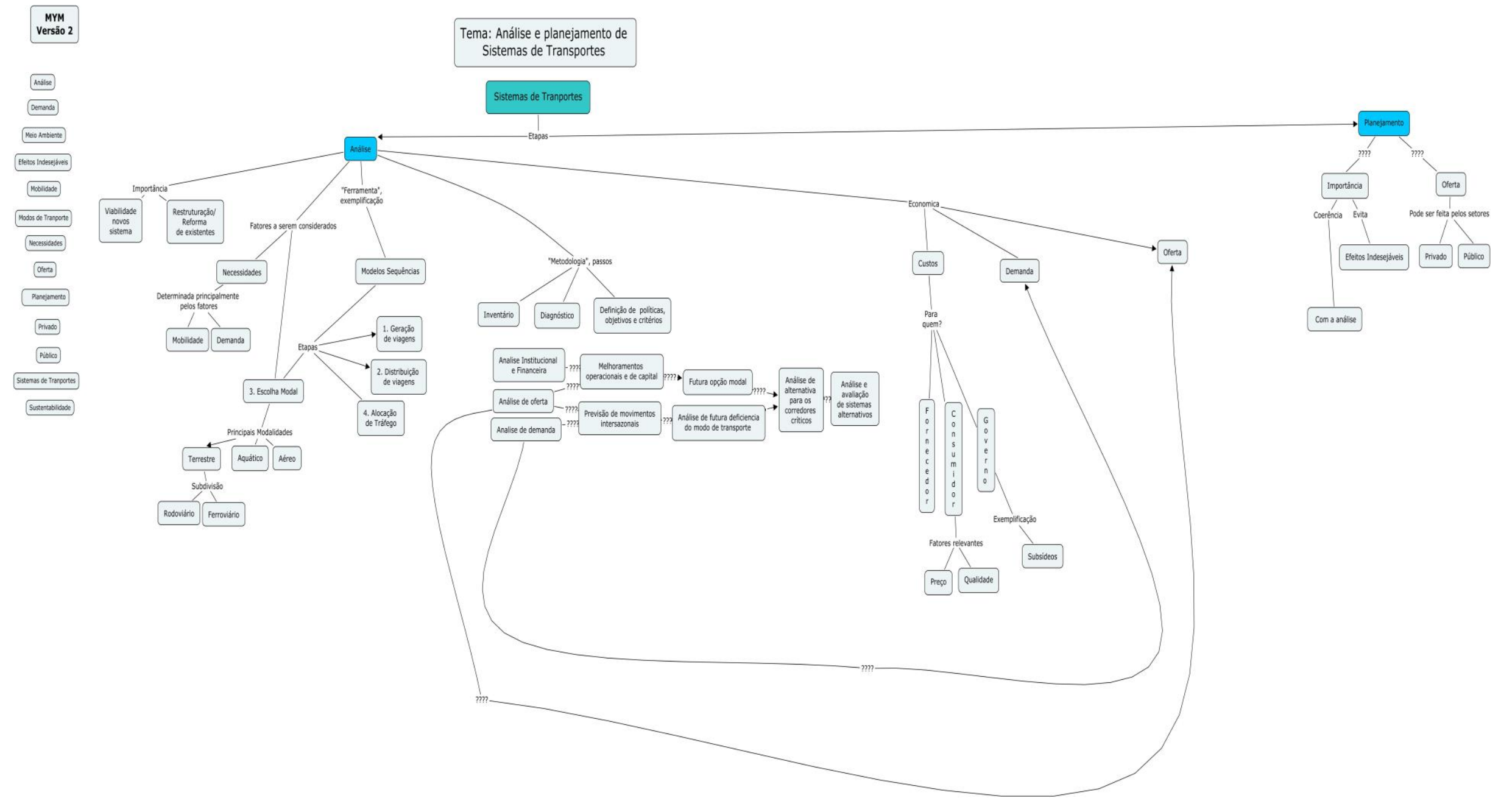


Versão 3

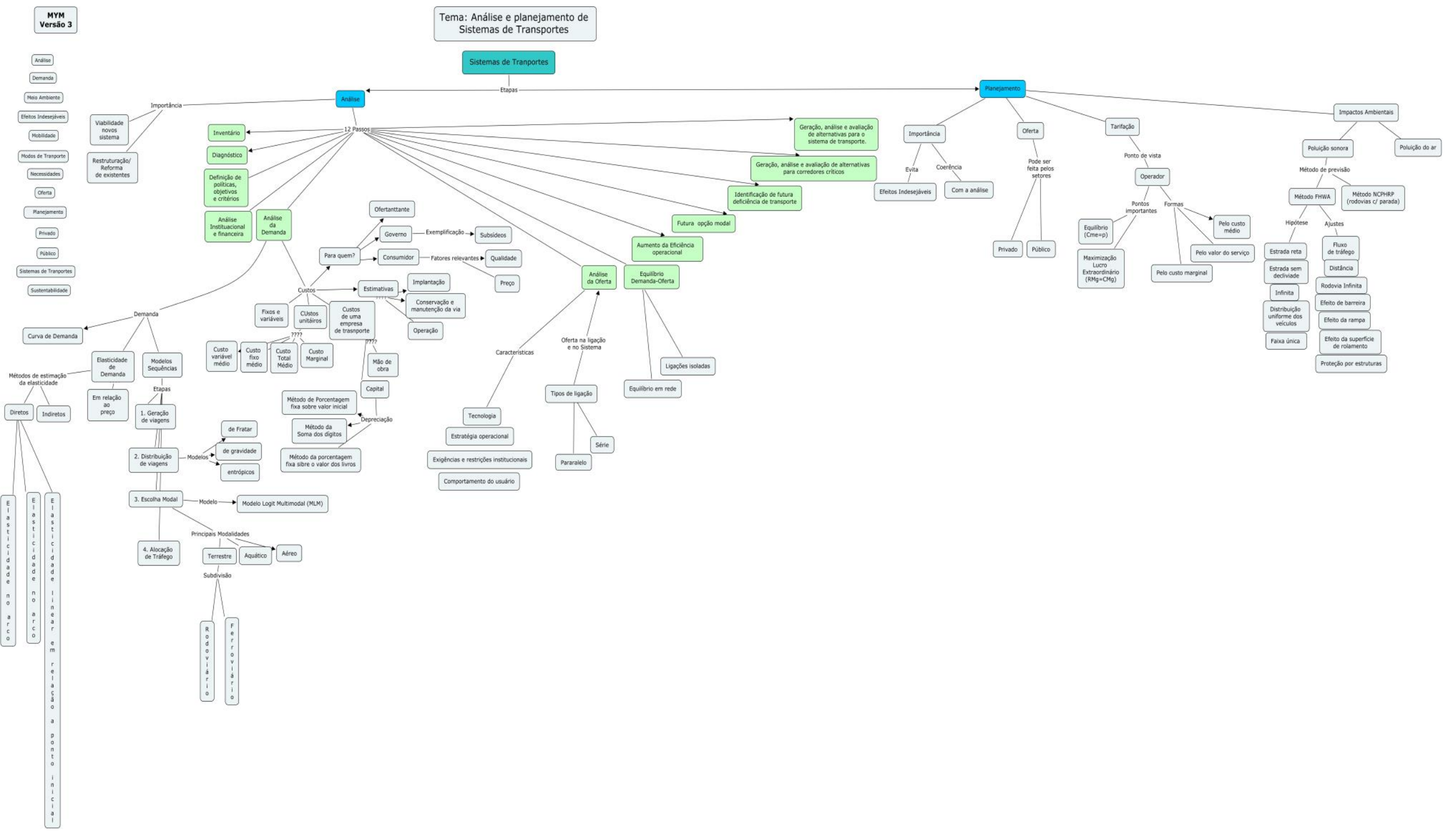




\section{VB - Versões 1, 2 e 3}

Versão 1

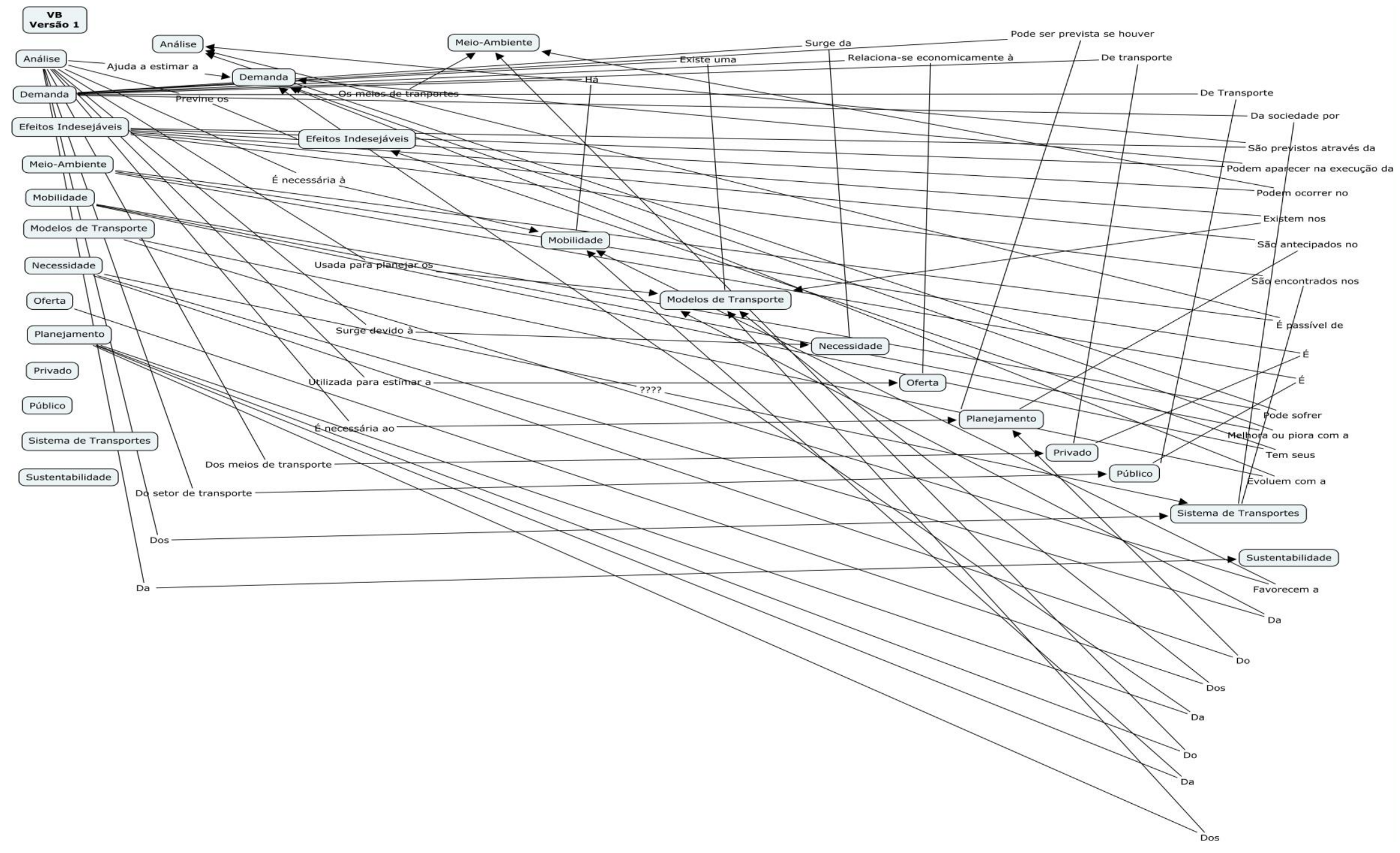




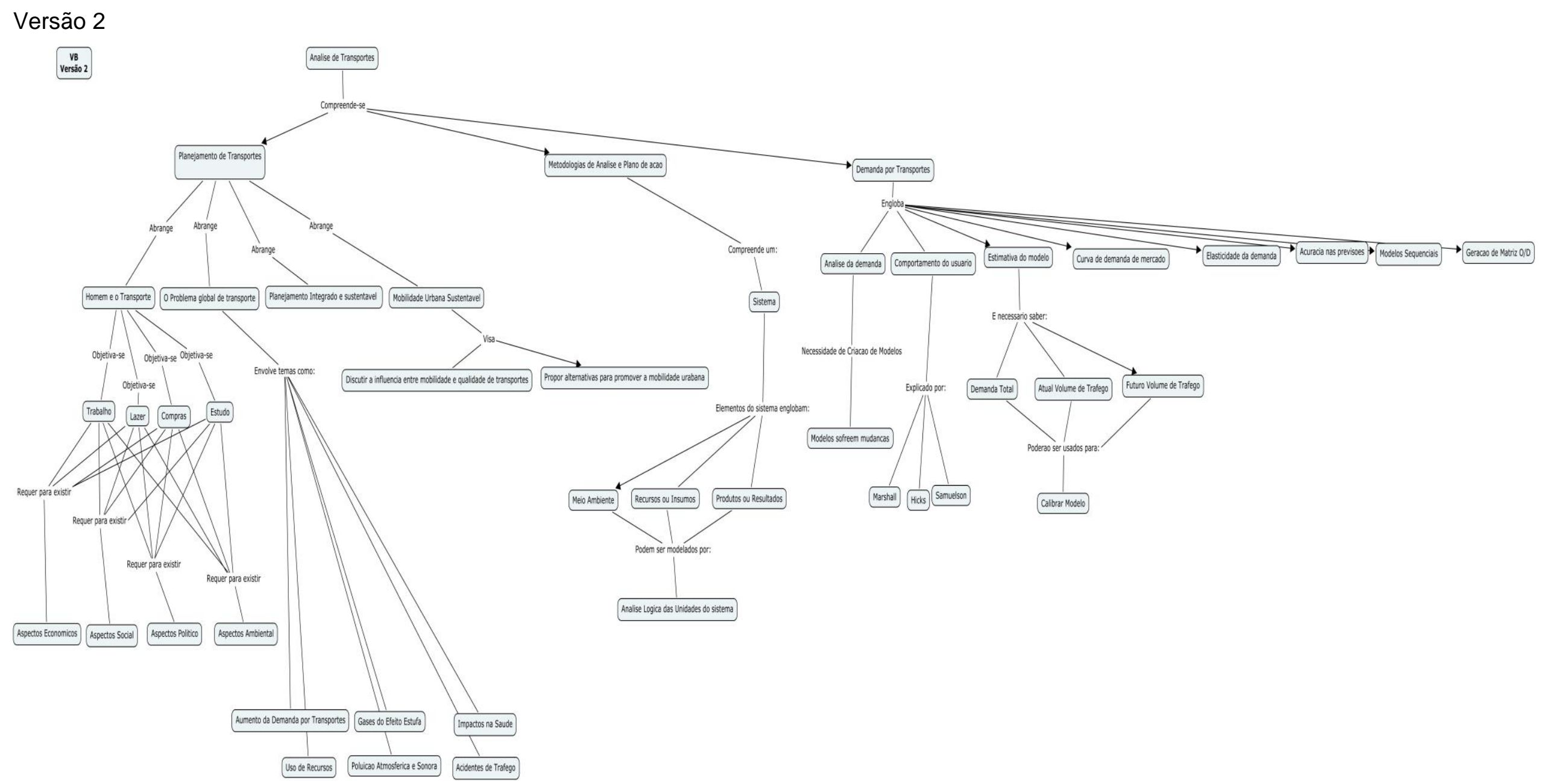




\section{Versão 3}

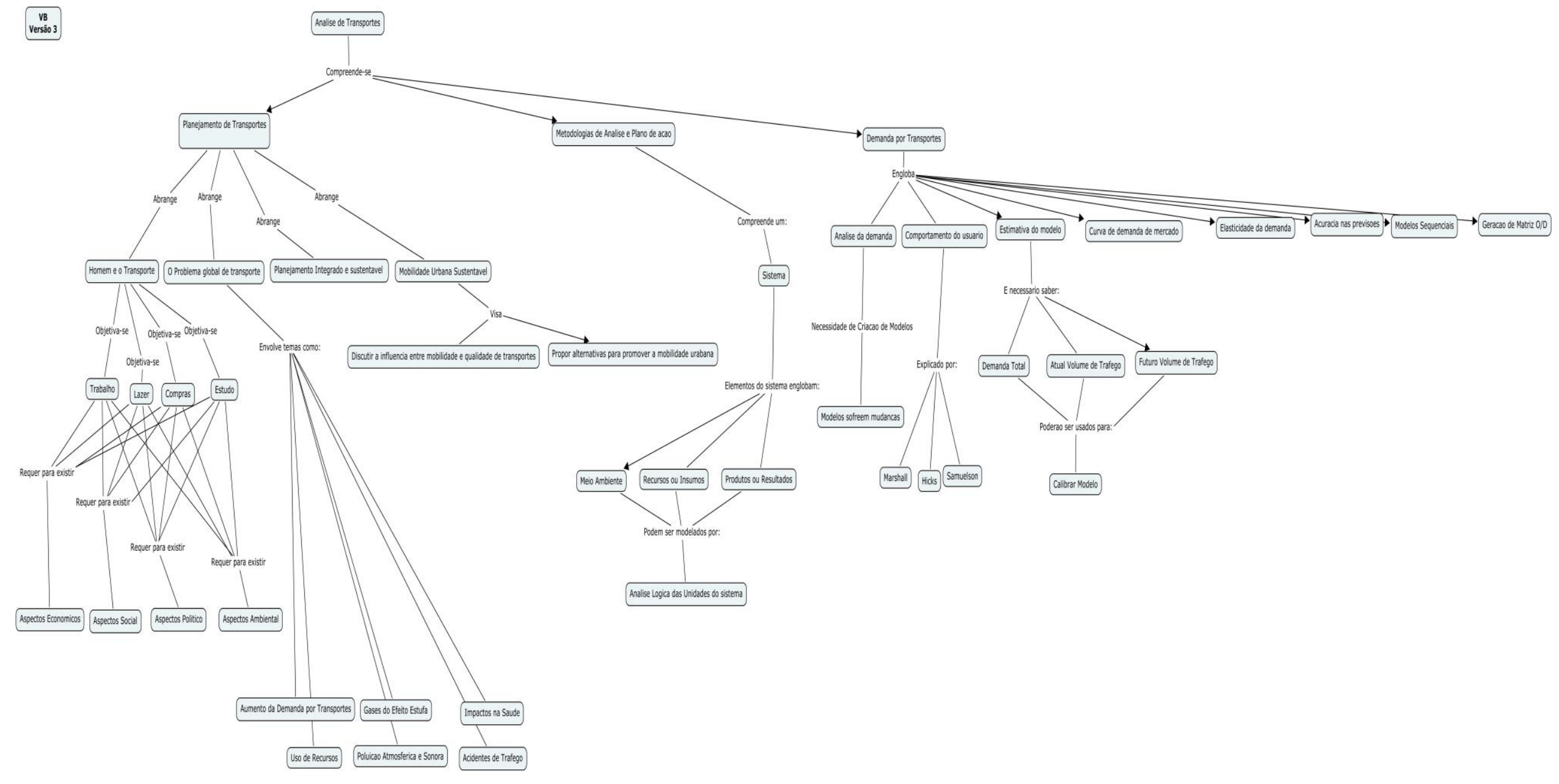




\section{TL - Versões 1, 2 e 3}

\section{Versão 1}

TL

Versão 1

TEMA:

Análise e Planejamento de Sistemas de Transportes

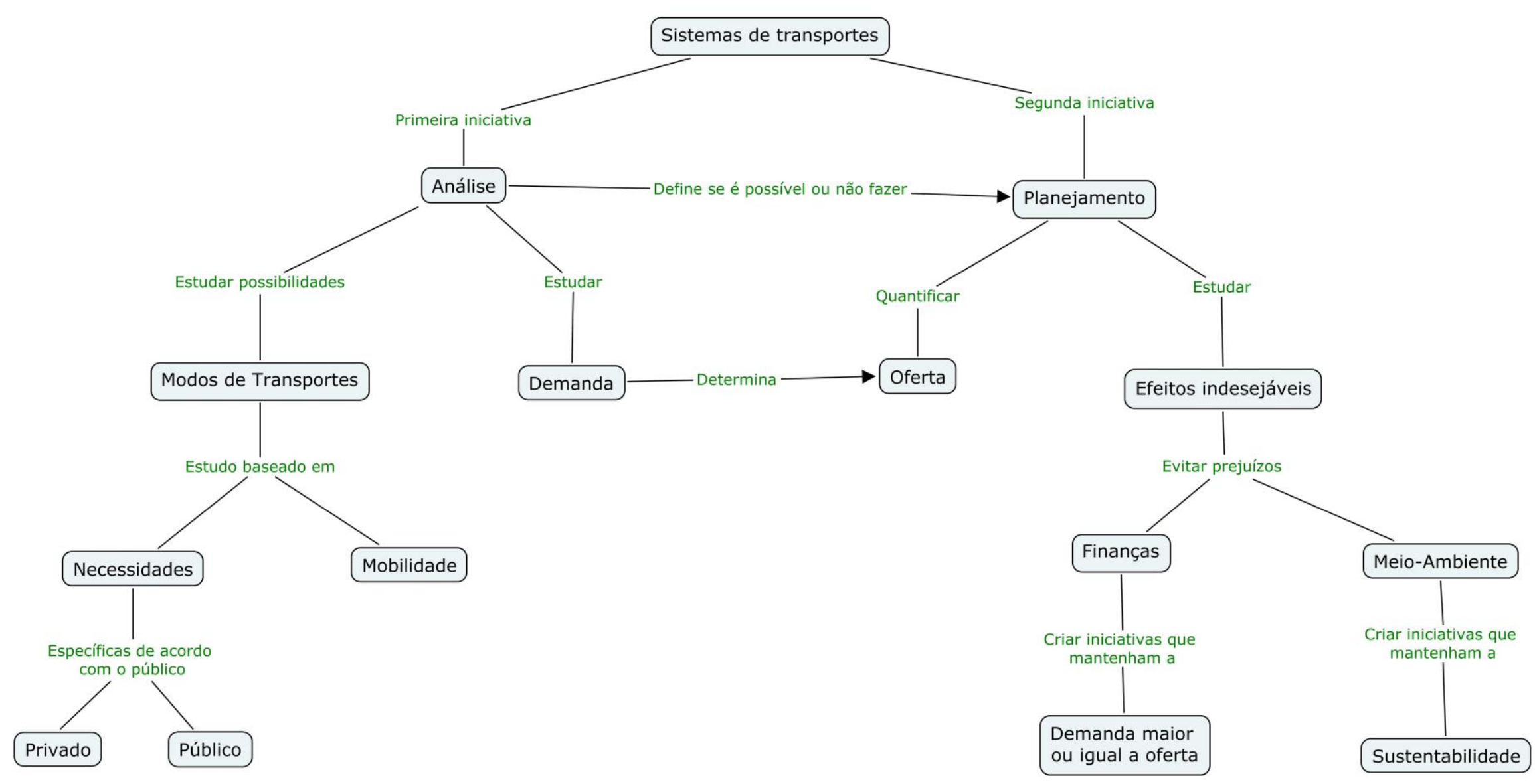




\section{Versão 2}

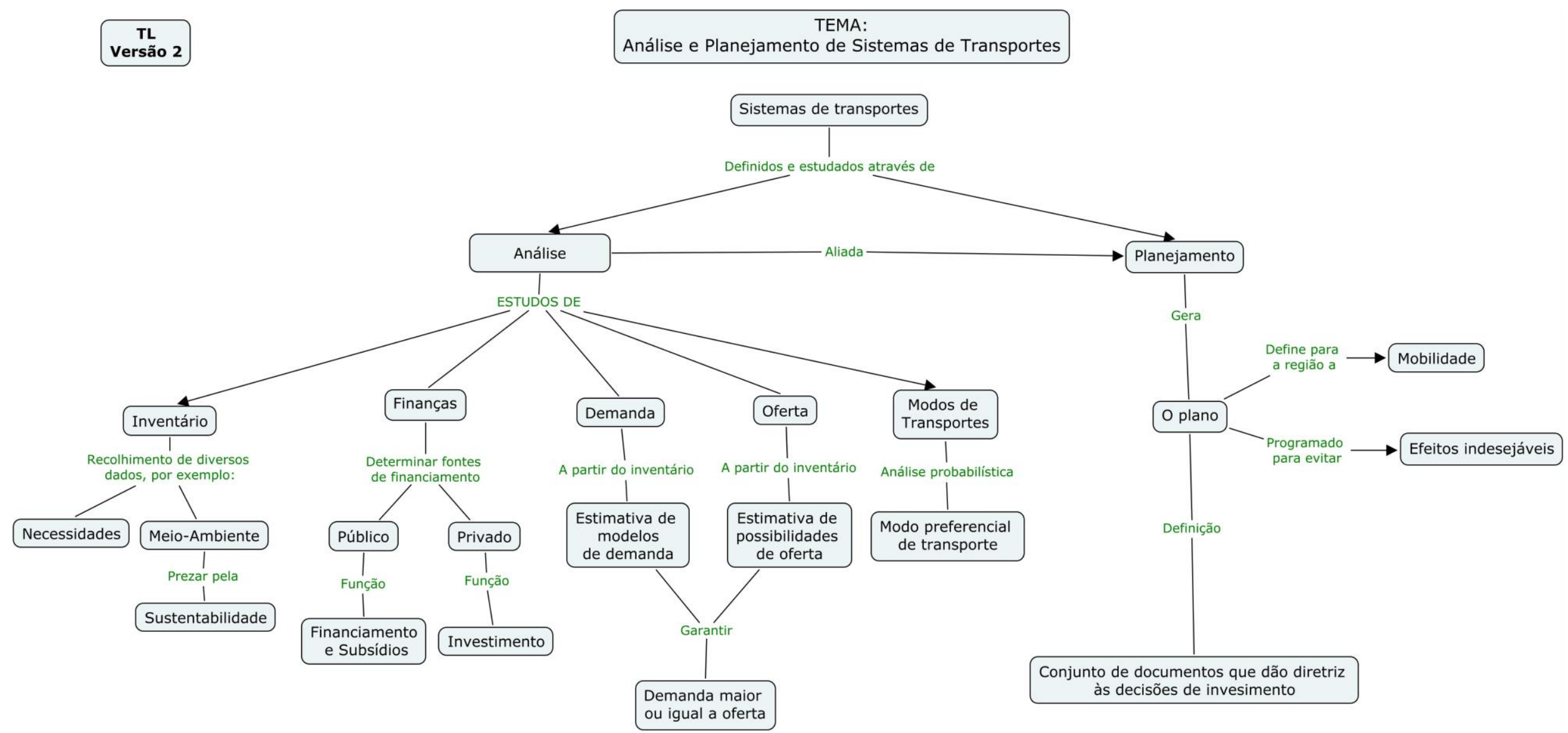




\section{Versão 3}

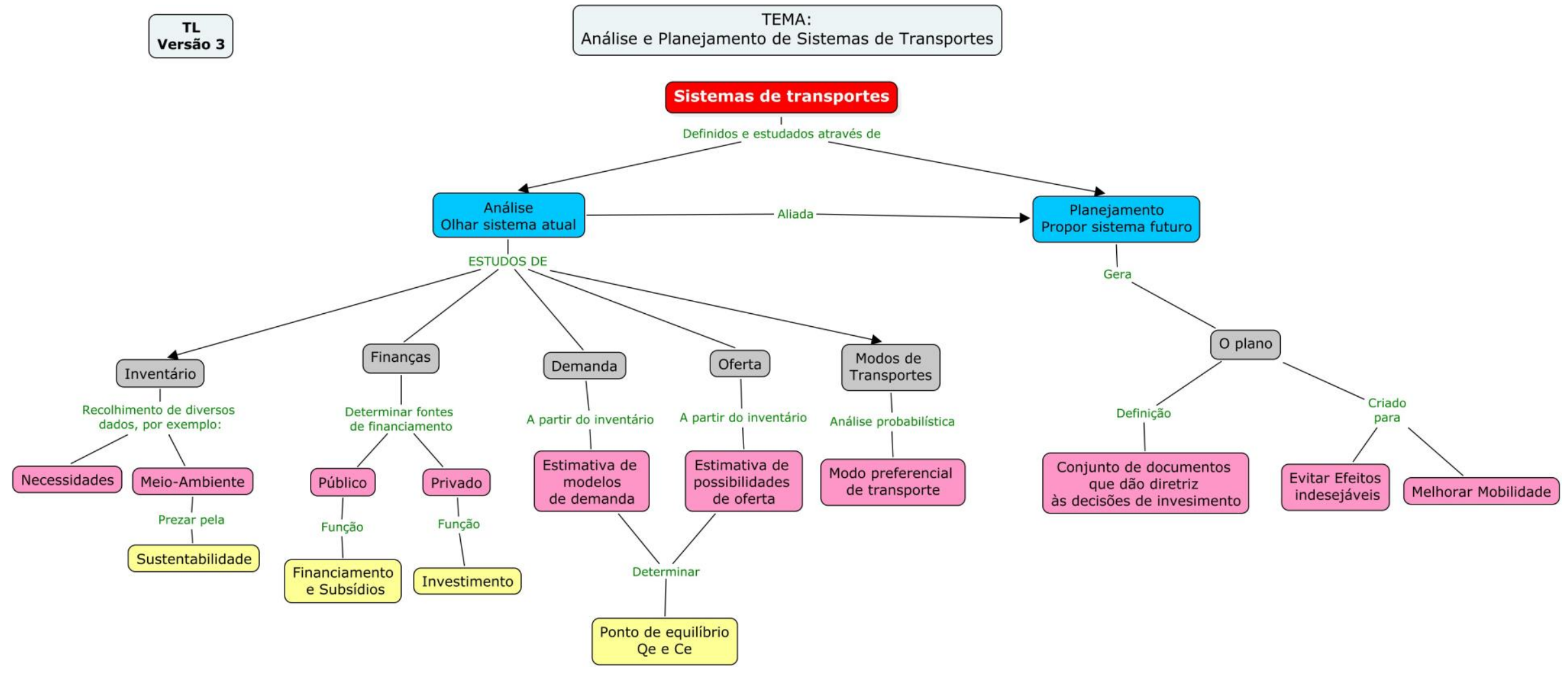




\section{ANEXO G. COMENTÁRIOS FEITOS PELOS ALUNOS NO QUESTIONÁRIO ONLINE - TURMA 2 DE 2013}

Percentual de comentários feitos no questionário online por aluno

\begin{tabular}{ccc} 
Aluno & Quantidade de Comentários & $\%$ \\
\hline AF & 1 & 2,22 \\
BF & 2 & 4,44 \\
CB & 1 & 2,22 \\
CN & 5 & 11,11 \\
CM & 1 & 2,22 \\
DS & 3 & 6,67 \\
EM & 1 & 2,22 \\
FM & 1 & 2,22 \\
IZ & 4 & 8,89 \\
JB & 5 & 11,11 \\
MYM & 5 & 11,11 \\
SN & 5 & 8,89 \\
TL & 4 & 4,44 \\
TB & 2 & 17,80 \\
VB & 8 & 2,22 \\
VS & 1 & 2,22 \\
Total & 1 & 100 \\
\hline
\end{tabular}

Questão 1: Você se sentiu à vontade em interagir com os colegas para o desenvolvimento das atividades extraclasse (inclusive online)?

\section{Aluno - CN}

Resposta: Às vezes

Comentário: Já que os grupos foram escolhidos levando-se em conta as diferenças entre as pessoas alguns membros do meu grupo eram conhecidos por não cooperarem.

\section{Aluno - TL}

Resposta: Às vezes

Comentário: É difícil conviver com pessoas diferentes da sua personalidade e do seu grupo de amigos. 
Questão 2: Considero mais fácil aprender os assuntos relacionados ao tema da disciplina de modo tradicional (ou seja, sem as atividades extraclasse).

Aluno - CN

Resposta: Neutro

Comentário: Depende da disciplina e da atividade extraclasse.

Aluno - BF

Resposta: Discordo

Comentário: O trabalho extraclasse é muito bom. O problema é o tempo de desenvolvimento escasso e a falta de um enunciado claro da proposta de projeto. Este último principalmente se fosse claro, não haveria problemas como apresentação de trabalhos repetitivos.

\section{Aluno - JB}

Resposta: Discordo totalmente

Comentário: Gostei bastante do projeto e dos grupos formados com pessoas diferentes. Não escolhemos com quem vamos trabalhar na vida profissional, então acho essencial trabalharmos com pessoas diferentes na faculdade. Penso que o projeto poderia substituir os testes já que é algo bastante trabalhoso.

\section{Questão 3: Você já havia acessado o Tidia-Ae antes?}

\section{Aluno - SN}

Resposta: Nunca

Comentário: Nunca, antes de cursar a disciplina de Planejamento e Análise de Sistemas de Transportes.

Questão 4: Como você avalia o ambiente de ensino Tidia-Ae?

Aluno - JB

Resposta: Bom

Comentário: Único problema é que é utilizada por poucos professores. Seria muito melhor se todas as disciplinas estivessem concentradas no Tidia-Ae.

\section{Aluno - DS}

Resposta: Bom 
Comentário: Vendo como atualmente os professores da USP ensinam em sala de aula e fornecem os materiais, o Tidia-Ae é excelente, simplesmente por fornecer tal material que a maioria não fornece, e também da forma q o fornece além de gerar discussão em forum.

Questão 5: Como você avalia o seu aprendizado?

Aluno - TB

Resposta: Melhor do que o esperado em uma disciplina presencial

Comentário: Por me interessar mais pela área de transportes

Questão 6: O nível de exigência das atividades extraclasse foi:

Aluno - CN

Resposta: Maior que as de uma disciplina convencional

Comentário: Diria que solicitou mais encontros e maior discussão.

\title{
Aluno - MYM
}

Resposta: Maior que as de uma disciplina convencional

Comentário: Maior que a maioria das disciplinas convencionais, mas semelhante a outras disciplinas ofertadas pelo departamento de transportes.

Questão 7: Você faria outra disciplina nesse formato, ou seja, com uma combinação de atividades em sala de aula e atividades extraclasse, se a USP oferecesse?

\section{Aluno - MYM}

Resposta: Sim

Comentário: Desde que o docente fosse dedicado e soubesse expor de modo adequado suas atividades, assim como ocorreu nessa disciplina.

\footnotetext{
Aluno - AF

Resposta: Sim
}

Comentário: As atividades extraclasses são fundamentais para aliar a teoria à prática

\author{
Aluno - DS \\ Resposta: Sim
}

Comentário: Justamente por fornecer bastante material e bastante exemplos para o futuro. 
Questão 8: Como você avalia o seu desempenho no projeto?

\begin{abstract}
Aluno - MYM
Resposta: Bom

Comentário: Não foi excelente devido a limitação temporal relacionada a quantidade de crédito total cursada.
\end{abstract}

Questão 9: Qual dos meios de interação providos foi o seu favorito?

\title{
Aluno - JB
}

Resposta: Atividade em grupo

Comentário: Acho que para algumas discussões reuniões presenciais rendem mais que fóruns ou conversar online (e-mail, facebook).

\section{Aluno - DS}

Resposta: Outro

Comentário: Material fornecido pelo Tidia e como, além do modo como foi feita as aulas com bastante interação com turma.

\begin{abstract}
Aluno - IZ
Resposta: Atividade em grupo

Comentário: Apesar de ter sido difícil, num primeiro instante, ter uma interação entre todos os integrantes, achei muito interessante ter pessoas com perfis diferentes para quebrar as "panelinhas" e desenvolver a habilidade de lidar com pessoas diferentes de nós (situação que encontraremos no ambiente de trabalho).
\end{abstract}

Questão 10: O que você achou da atividade de projeto?

\footnotetext{
Aluno - TB

Resposta: Regular

Comentário: Achei que o objetivo ficou um pouco vago. Tanto que na hora que questionei meu grupo sobre como daríamos o peso, eles me disseram pra levar em consideração quais critérios eu achava mais importante. Indaguei se a importância era pra mim pessoalmente ou em relação à mobilidade e cada um respondeu uma coisa. Naquele momento, vi que alguns nem sabiam a razão inicial do trabalho; o "por quê" de se criar tal índice. Tanto que nossa $1^{\underline{a}}$ árvore fazia referência à escolha feita pelo estudante do tipo de viagem que ele faria, e nada relacionado à mobilidade no campus.
} 


\section{Aluno - SN}

Resposta: Excelente

Comentário: Excelente, pois foi realizado através de uma abordagem diferente da convencional.

\section{Aluno - TL}

Resposta: Regular

Comentário: Ficou muito corrido realizar o projeto.

\section{Questão 11: Como você avalia o conteúdo da disciplina?}

\section{Aluno - MYM}

Resposta: Interessante e útil

Comentário: Com certeza a análise da mobilidade do campus é útil visto os resultados obtidos. E interessante visto ao modo como foi abordado.

\section{Questão 12: Qual é a sua avaliação global para essa disciplina?}

\section{Aluno - CN}

\section{Respostas: Boa}

Comentário: Boa, porém algumas posturas do professor, como contar o tempo fora da aula e obrigar todos a falar deixa os alunos tensos.

\section{Aluno - IZ \\ Resposta: Muito boa}

Comentário: O professor tem uma habilidade muito grande de transmitir seus conhecimentos, principalmente ao utilizar imagens, gráficos e exemplos fáceis, que ajudam até durante a prova. A insistência em exigir as discussões em duplas provocavam um desconforto (principalmente porque o tempo era curto e tinha que repassar na lousa), mas facilitavam a lembrança da matéria durante a prova.

Questão 15: As tarefas dessa disciplina tomaram mais tempo do que as tarefas de outras disciplinas.

\section{Aluno - TB}

Resposta: Neutro 
Comentário: Disciplinas com projetos sempre ocupam mais tempo, mas vale pela "chance" a mais de melhorar a nota.

Aluno - IZ

Resposta: Discordo

Comentário: Tinha receio de o trabalho em grupo tomar muito tempo, mas como era possível fazer reuniões apenas para discutir os assuntos e depois dividir as tarefas, deu para administrar bem o tempo livre.

Questão 16: O que você achou da utilização do Tidia-Ae na disciplina?

Aluno - EM

Resposta: Bom

Comentário: Dinamizar a troca de informações.

Questão 17: Houve coerência entre o conteúdo ministrado e o exigido nas atividades realizadas extraclasses.

Aluno - TB

Resposta: Neutro

Comentário: Creio que eram modos de pensar diferentes sobre um mesmo tema.

Aluno - CB

Resposta: Discordo

Comentário: Concordo somente na P2.

Questão 18: A proposta da disciplina, com atividades em sala de aula e atividades extraclasse (inclusive on-line), foi:

\section{Aluno - VS}

Resposta: Boa

Comentário: Achei injusto a apresentação do projeto valer $1 / 4$ da nota enquanto o fórum valeu $3 / 4$ da nota. Deveria ser ao contrario.

\section{Aluno - CR}

Resposta: Regular 
Comentário: Não gosto da metodologia de resolver exercícios em duplas durante a aula e idas à lousa, pois entendo melhor o conteúdo quando raciocino sozinha e sem pressa ou pressão.

Questão 19: O professor estimulou a formação do espírito crítico.

Aluno - SN

Resposta: Concordo totalmente

Comentário: Através do projeto, o grupo analisou o problema proposto com os conhecimentos adquiridos. E no dia da apresentação, pode-se conhecer e comparar as diferentes análises e propostas de soluções. Quase todas, perfeitamente realizáveis.

\title{
Questão 20: A navegacão pelas páginas do Tidia-Ae foi:
}

Aluno - IZ

Resposta: Adequada, porém levei um tempo para compreendê-la

Comentário: O mais difícil foi encontrar o material que era passado em sala de aula. Creio que o nome deveria ser mais claro (e não "MODULES").

Questão 21: Você teve dificuldades para confeccionar seus Mapas Conceituais?

\section{Aluno - TB}

Resposta: Sim

Comentário: Sigo uma linha de raciocínio muito contínua, e achei muito difícil expressar isso através do mapa (ele parece exigir conexões de palavras e divisões de ideias que eu não costumo fazer, então não consegui fazer um mapa que me agradasse.

\section{Aluno - FM \\ Resposta: Outro}

Comentário: Por ter faltado em algumas aulas, fiz apenas um mapa conceitual. Porém, já tinha trabalhado bastante com essa técnica no ensino médio, portanto não tive dificuldades na confecção.

Questão 22: Em termos de quantidade, os 13 conceitos sugeridos foram suficientes.

\author{
Aluno - JB \\ Resposta: Neutro
}


Comentário: Para o primeiro mapa, sim, mas imagino que poderiam ter sugerido novos conceitos para os próximos mapas.

Questão 23: Você utilizou o programa CmapTools para fazer outras atividades além daquelas solicitadas pelo docente?

Aluno - MYM

Resposta: Sim

Comentário: Muito útil. Agradeço a oportunidade de aprender a utiliza-lo.

Questão 24: De uma forma geral, qual sua opinião sobre os Mapas Conceituais?

Aluno - TB (observar resposta deste aluno na questão 21)

Resposta: Interessante e útil

Comentário: Talvez se eu tivesse me esforçasse mais, poderia ter desenvolvido este meu ponto fraco de não conseguir montar um mapa muito complexo.

Questão 25: Você faria uma disciplina em que o único meio de avaliação do aprendizado fosse a confecção de Mapas Conceituais?

Aluno - JB

Resposta: Não

Comentário: Trabalhos em campo e projetos são de extrema importância para um curso de engenharia, na minha opinião. Penso que além de saber conceitos temos que saber aplicálos.

Aluno - DS

Resposta: Sim

Comentário: Depende muito de como seria feito essa disciplina, pois teria q ser algo mais geral, envolvendo não somente transporte, mas economia, gestão e logística, etc.

Questão 27: Você acha que a versão final do seu Mapa Conceitual pode representar a sua média na disciplina?

Aluno - CN

Resposta: Outro 
Comentário: Não sei como será a avaliação desse mapa conceitual, por isso prefiro não opinar.

Aluno - VB

Resposta: Sim

Comentário: Se for maior do que a media atual.

Questão 28: O que você achou mais difícil na confecção dos Mapas Conceituais?

Aluno - BF

Resposta: Fazer ligações coerentes entre os conceitos

Comentário: Todos os conceitos estão interligados de uma forma.

Aluno - TB

Resposta: Outra

Comentário: Minha maior dificuldade foi "ramificar" os conceitos, para que a árvore não ficasse com apenas uma linha (literalmente) de raciocínio (com um conceito logo embaixo do outro).

Questão 29: Você faria outros usos para o recurso "Mapa Conceitual" durante o curso de Engenharia Civil?

Aluno - TB

Resposta: Sim

Comentário: Acredito que seja uma ótima maneira de estudar pra quem não consegue memorizar conceitos a partir de textos compridos. Pode ser utilizado em qualquer matéria mais teórica, sem muitos cálculos (exemplo: materiais de construção).

\section{Aluno - SN \\ Resposta: Sim}

Comentário: Fazer resumos do conhecimento adquirido em sala de aula, de modo que se possa organizar e hierarquizar os conceitos, e relacioná-los entre si. 